\title{
UNIVERSITE DE BOURGOGNE
}

\section{UMR Procédés Alimentaires et Microbiologique (PAM)}

(Equipe Procédés Alimentaires et Physico-Chimie - PAPC)

\begin{abstract}
THESIS
Presented in partial fulfilment of the requirements for the degree of Doctorate of Philosophy in Food Sciences
\end{abstract}

Presented by

\section{SILAWAN SOMBOONCHAN}

Thesis defense examination: December $18^{\text {th }} 2015$

Water and temperature contribution to the structuration of starch matrices in the presence of flavour

(Contribution de l'eau et de la température à la structuration de matrices d'amidon en présence d'arômes)

Thesis director: Assoc. Prof. Gaëlle Roudaut, PhD

Thesis co-supervisor: Assoc. Prof. Samuel Lubbers, PhD

Thesis committee:

Prof. Bernard Cuq

SupAgro-Montpellier, France

Reviewer

Prof. Onanong Naivikul

Kasetsart University, Bangkok, Thailand

Reviewer

Prof. Dominique Champion

AgroSup-Dijon, France

Examiner

Prof. Stéphane Desobry

ENSAIA, Université de Lorraine, France

Examiner

Assoc. Prof. Gaëlle Roudaut AgroSup-Dijon, France

Thesis director

Assoc. Prof. Samuel Lubbers AgroSup-Dijon, France

Thesis co-supervisor 
It is my pleasure to acknowledge on the supports of these following people which enable me to attain this thesis successfully:

First of all, I would like to express my appreciation and sincere gratitude to my thesis director "Gaëlle Roudaut", firstly for her confidence in me by accepting me doing this PhD. I would like to thank you for her kindness, valuable advice, long lasting guidance, encouragement and the warmth (as well as from Colin and Eloi) throughout the time in Dijon.

Special gratitude is given to my co-supervisor "Samuel Lubbers" for his kindness, valuable advice, long lasting guidance, encouragement and support throughout the study.

The special thanks are given to my advisory committee "Natalie Cayot and Denis Lourdin for their valuable and constructive comments, suggestions, and encouragement for the completion of this study. My special appreciation is expressed to Prof. Onanong Naivikul, Prof. Bernard Cuq and Prof. Stéphane Desobry for their kindness, valuable time and extensive advices.

I thanks profusely to Qi Statistics Ltd., in particularly to Anne Hasted for an exceptional kindness, financial support, material support, valuable advices, encouragement and care throughout the study. Without you, I cannot come at this far.

I would like to express my deepest sincere gratitude to French Embassy in Thailand for the discovery scholarship and their supports.

My thanks also due to Julien for scholarship news, encouragement and supports throughout application period. I acknowledge with thanks to Dr. Wilatsana Posri, Dr. Mutita Meenune, Dr. Juntanee Uriyapongson and all of my former professors for their kindness, advices, encouragement and supports. I would like to thanks to Siam-Photon, Synchrotron Light Research Institute - Dr. Supagorn Rugmai, Dr. Siriwat Soontaranon, Dr. Sirinart Srichan for their exceptionally kindness, advices, and all services for the WAXS, SAXS, and FTIR experiments in Thailand.

Special thanks also are given to all of my trainees: Tatiana Starciuc, Caroline Kothe, and Gabriel K. da Rocha Mitani for all the grateful and hard working times that we spent together.

Special grateful are also given to all fellows and colleagues particularly, Leila, Nadège (and friends), Lucie, Manal, Attaf, Mohamed, Yanis, Sofynne, Supuksorn, Nisarat, Nuttida, Pannarai, Natcha, Anuwat, Pensak, Chaba Thai restaurant (Yaowapa, Prasitthiphon \& Prakorn), Cristina, Alina, all Thai-exchanged students (Atitaya, Chavis, Pathomporn and Pattarabhorn) and all the friends in Dijon for giving me a kindly assistance, meaningful time and unforgettable friendship. Thanks to the help on French language of Leila and Nadège, I adapted to the life in Dijon quickly. You both are my best French teachers. I would like to thanks to haven or whoever sent Leila to Dijon. I could not imagine how my life would be without her kindness, helps and friendship. 
I wish to extend many thanks to Bernadette who always support and provide me facilities used in my lab as well as the hugs when I need. The thanks also given to Alexandra, Claire, Monique for her kindly support and to and all PAPC team who always support and encourage me.

I am grateful and impressed by the generosity and outstanding friendship of Laurent, Patricia Lempeurer, Patricia Lllorca, Saiwaroon and their families.

I would like to give my special thanks to Adrien, Phillipe, Gary and Natil'UB friends. The time I spent with you on badminton and Scuba diving were very helpful for my stressful life. The deepest gratitude is also for Vanapit and Chaturon for their kindness and hospitality anytime I need to stay in Paris.

I would like to thank all my dear adopted-sisters and friends: Nantanart, Sirinart, Sirichat, Suppawan, Chutintorn, Suly, Pascal, Bérangère and all the friends SKN, Nestlé, Dresden, Erasmus Mundus, PSU, Mahidol and CIF friends for always giving me the will power, the courage, the helps (anytime I need) and sharing happiness and tear with me via every means (personally, phone, email, social network and etc.).

I am grateful to Hasted family and friends: Anne, Keith, Alice, Cara, Will, Rich, Jude, Ezra, Ann, Ron, Di and John for their kind, happiness, support, encouragement, love, care, hugs and the second home that have been given to me ever since I know you.

My deepest gratitude was given to my family: aunt, mum, uncles, brothers, cousins, niece and nephew for their infinite love, understanding, supports, joy, tears and the parcels of Thai food every few months.

I would like to thank Jean-Christophe for being good listener, patient, kind and helpful to me. I am thankful that you always calm me down, understand and taking care of me through the hard times.

Finally, I would like to dedicate this doctoral degree to my beloved father who asked me to study medicine when I was very young. "Dear dad, I am sorry. My interest was changed when you were gone, I lost my motivation somehow. Well, I cannot give you a Doctor of Medicine but I give you a Doctor of Food Science. It is much more fun." Wherever you are, please know that I "did" it and I did it for you. I love you.

I apologise that I cannot mention every names here. Please be informed that I always thankful for your warmth, kindness, encouragement, support, love and care. 


\section{Remerciement}

Je pense, ma thèse sera lu par seulement quelques personnes, donc j'imprime cette partie pour vous tous. Je ne pouvais pas venir à cette étape sans ces personnes suivantes

Tout d'abord, je tiens à exprimer ma gratitude à ma directrice de thèse "Gaëlle Roudaut", pour sa confiance en moi et m'a avoir accepté de faire une thèse. Je voudrais la remercier pour sa gentillesse, ses conseils, ses encouragement et de la chaleur (de Colin et d'Eloi) pendant tout ce temps à Dijon.

Je tiens à remercier mon co-directeur de thèse "Samuel Lubbers" pour sa gentillesse, des conseils, des encouragements et de soutien tout au long de mon étude.

Les remerciements particuliers sont donnés à mes comités de thèse "Natalie Cayot et Denis Lourdin " pour leur commentaires précieux. Je voudrais remercier spécialement les jures: Prof. Onanong Naivikul, Prof. Bernard Cuq et Prof. Dominique Champion pour leur gentillesse, leurs temps précieux et leurs nombreux conseils.

Je tiens à remercier profondément à Qi Statistiques Ltd., en particulier Anne Hasted pour sa gentillesse exceptionnelle, un soutien financier, un soutien matériel, des conseils précieux, de l'encouragement. Sans toi, je n'aurais pas pu venir à ce jour. Je tiens à exprimer ma plus profonde gratitude sincère à l'ambassade française en Thaïlande pour la bourse découverte et de leurs supports.

Mes remerciements également à Julien de trouver cette bourse de l'ambassade et de l'aide pour obtenir la bourse. Des remerciements particuliers sont également donnés à mes stagiaires: Tatiana Starciuc, Caroline Kothe, et Gabriel K. da Rocha Mitani.

Je remercie Dr. Wilatsana Posri, Dr Mutita Meenune, Dr Juntanee Uriyapongson et tous mes anciens professeurs pour leurs conseils, encouragement et soutien. Je voudrais remercier SiamPhoton, Synchrotron Light Research Institute Light - Dr Supagorn Rugmai, Dr Siriwat Soontaranon, Dr Sirinart Srichan pour leurs exceptionnellement gentillesse, conseils, et tous les services pour les expériences sur WAXS, SAXS, et FTIR en Thaïlande.

Je tiens à mercier énormément à Leila, Nadège (et ses amis), Lucie, Manal, Supuksorn, Attaf, Mohamed, Yanis, Sofynne, Nisarat, Nuttida, Pannarai, Natcha, Anuwat, Pensak, restaurant Chaba Thai (Yaowapa, Prasitthiphon \& Prakorn), Cristina, Alina et tous les amis à Dijon pour leurs aides et les amitiés inoubliable. Grace à Leila et Nadège, je me suis adaptée à la vie de Dijon rapidement. Vous êtes à la fois mes meilleurs professeurs de français et amis.

Je tiens à adresser un grand merci à Bernadette pour son soutien et m'a fourni des installations utilisées dans mon laboratoire ainsi que ses câlins (quand j'ai eu besoin). Les grâces également donnés à Alexandra, Claire, Monique et toute l'équipe PAPC pour leurs aimables soutiens. 
Je suis reconnaissant et impressionné par la générosité et l'amitié exceptionnelle de Laurent, Patricia Lempeurer, Patricia Lllorca, Saiwaroon et de leur famille.

Je voudrais exprimer mes remerciements spéciaux à Adrien, Phillipe, Gary et Natil'UB amis. Le temps passé avec vous sur le badminton et Plongée sous-marine était très serviable pour ma vie stressante. La plus profonde gratitude est aussi à Vanapit et Chaturon pour leur gentillesse et I'hospitalité chaque fois que je dois rester à Paris.

Je tiens à remercier toute mes sœurs adoptives et les amis: Nantanart, Sirinart, Sirichat, Suppawan, Chutintorn, Suly, Pascal, Bérangère et les amis de SKN, Nestlé, Dresden, Erasmus Mundus, PSU, Mahidol, CIF pour toujours me donner le pouvoir de la volonté, le courage, l'aide et partager le bonheur et à la déchirure avec moi par tous les moyens (personnellement, téléphone, email, réseaux sociaux, etc).

Je suis reconnaissant à la famille et les amis Hasted: Anne, Keith, Alice, Cara, Will, riche, Jude, Ezra, Ann, Ron, Di et John pour leurs nature, le bonheur, le soutien, l'encouragement, l'amour, les soins, câlins et deuxième maison qui ont été donné à moi depuis que je vous connais.

Ma profonde gratitude a été donné à ma famille: ma tante, maman, oncles, frères, cousins, cousines, neveux et nièces pour leur amour infini, la compréhension, le soutien, la joie, les larmes et les colis de nourriture thaie tous les quelques mois.

Je tiens à remercier Jean-Christophe pour être bon auditeur, patient, gentil et serviable pour moi. Je suis reconnaissante de comprendre et de prendre soin de moi dans les moments difficiles.

Enfin, je tiens à dédier ce doctorat à mon père bien-aimé, qui m'a demandé d'étudier la médecine quand j'étais très jeune. «Cher papa, je suis désolée. Mon intérêt a été changé lorsque tu es parti, j'ai perdu ma motivation en quelque sorte. Eh bien, je ne peux pas te donner un docteur en médecine mais je te donne un docteur en sciences de l'alimentation. Il est beaucoup plus amusant. "Partout où tu es, s'il te plaît sache que je l'ai fait pour toi. Je t'aime.

Je suis désolée que je ne puisse pas citer tous les noms ici. Je tiens à merci pour votre aimable, les encouragements et les soutiens d'amour.

Silawan Somboonchan (Koï) 
วิทยานิพนธ์ระดับดุษฎีบัณฑิตเล่มนี้คงไม่สามารถสำเร็จได้ หากไม่ได้รับความความอนุเคราะห์จากบุคคลหลาย ท่านดังต่อไปนี้

ผู้มีพระคุณท่านแรกคืออาจารย์ผู้ควบคุมวิทยานิพนธ์ Gaëlle Roudaut ขอขอบพระคุณจากใจจริงสำหรับความ ไว้วางใจและมั่นใจที่มีให้กับคนที่ไม้รูจจกกันมาก่อน โดยตอบรับเป็นอาจารย์ที่ปรึกษา สำหรับความช่วยเหลือ มิตรไมตรี แรงกระตุ้น คำแนะนะ ที่มีให้มาเสมอๆ พร้อมทั้งความอบอุ่นจากลูกๆ ของอาจารย์ Colin และ Eloi ตลอดเวลาที่อยู่ที่ Dijon

ใคร่ขอขอบคุณ Samuel Lubbers เป็นพิเศษ สำหรับความช่วยเหลือ คำแนะนำ และแรงกระตุ้นที่มีให้เสมอมา

ใคร่ขอขอบคุณคณะกรรมการควบคุมวิทยานิพนธ์ และกรรมการการสอบป้องกันวิทยานิพนธ์ อันได้แก่ Natalie Cayot, Denis Lourdin, ศาสตราจารย์อรอนงค์ นัยวิกุล, Prof. Bernard Cuq และ Prof. Stéphane Desobry เป็นพิเศษ สำหรับคำแนะนำ และเวลาอันมีค่า

ขอขอบคุณบริษัท Qi Statistics Ltd. โดยเฉพาะอย่างยิ่ง Anne Hasted ผู้ซึ่งมีพระคุณอย่างหาที่สุดมิได้ ผู้ที่มี ความเชื่อมั่นในตัวก้อยว่ามีความสามารถที่จะเรียนต่อระดับปริญญาเอก และมอบค่าใช้จ่ายเป็นทุนการศึกษาตลอดเวลาที่ เรียนปริญญาเอก พร้อมทั้งยังช่วยสนับสนุนด้านต่างๆ ให้คำแนะนำที่มีประโยชน์ ให้กำลังใจ ให้การดูแลประหนี่งลูกอีกคน ถ้าไม่มี Anne ก้อยคงไม่มีวันนี้

ขอขอบคุณสถานทูตฝรั่งเศสประจำประเทศไทย และเจ้าหน้าที่ด้านการศึกษาและมหาวิทยาลัย สำหรับทุน découverte และการประสานงานต่างๆ

ขอบคุณ Julien ที่ช่วยหาข้อมูลของทุนการศึกษา ช่วยตรวจสอบเอกสารการสมัครและเป็นแรงกระตุ้นให้เรียน ปริญญาเอก ขอขอบพระคุณอาจารย์บี (วิลัสนา โพธิศรี) อาจารย์โม (มุทิตา มีนุ่น) อาจารย์จันทร์ (จันทนี อุริยะพงศ์สันต์) อาจารย์เสาวลักษณ์ พงศ์ไพจิตร อาจารย์เมตตา องค์สกุล อาจารย์ศุภยางค์ วรวุฒิคุณชัย อาจารย์แก้ว (สิทธิวัฒน์ เลิศศิริ) อาจารย์อภิญญา อัศวนิก อาจารย์ไพโรจน์ หลวงพิทักษ์ และอาจารย์ทุกๆ ท่านทั้งที่มหาวิทยาลัยสงขลานครินทร์ และ มหาวิทยาลัยมหิดล สำหรับคำสั่งสอน ความเป็นห่วง คำแนะนำ กำลังใจ และแรงกระตุ้น กราบขอบพระคุณครูอาจารย์ ทุกท่าน ทุกระดับชั้นตั้งแต่ก่อนประถมวัย จนถึงปริญญาเอกที่ได้สั่งสอน ให้วิชา และทำให้ก้อยมีวันนี้ได้

ขอขอบพระคุณสถาบันวิจัยแสงซินโครตรอน ดร. ศุภกร รักใหม่ ดร. ศิรัวัช สุนทรานนท์ ดร. สิรินาถ ศรีจันทร์ เป็น อย่างสูง สำหรับการสนับสนุนการทดลอง WAXS, SAXS และ FTIR พร้อมทั้งการดูแลด้านชีวิตความเป็นอยู่ตลอดช่วงเวลา ที่ทำงานที่สถาบัน

ขอขอบคุณนักศึกษาฝึกงานทั้ง 3 (Tatiana Starciuc, Caroline Kothe, Gabriel K. da Rocha Mitani) ที่ได้มา ทำงานวิจัยร่วมกันแม้จะเป็นช่วงเวลาสั้นๆ

ขอขอบคุณเพื่อนๆ ที่ Dijon ทุกคนโดยเฉพาะ Leila, Nadège (และผองเพื่อนของ Nadège), Lucie, Manal, Attaf, Mohamed, Yanis, Sofynne, พี่แอน น้องนิว น้องตุ้ม ปลา น้องปลา ปิง แอม พี่ๆ ที่ร้านชบาไทย (พี่เยา พี่อ้อย พี่ ปกรณ์) Cristina, Alina, น้องๆ นักเรียนไทยที่มาแลกเปลี่ยน (น้องฝน น้องพอร์ช น้องชะเอม น้องแชมป์) สำหรับช่วงเวลา ดีๆ ความสนุกสนาน ความทรงจำ คำแนะนำ ความช่วยเหลือ และมิตรภาพที่ไม่อาจจะลืมได้ ขอบคุณ Leila และ Nadège เป็นพิเศษที่ช่วยสอนภาษาฝรั่งเศสให้ ทั้งสองคนคือครูสอนภาษาฝรั่งเศสที่ดีที่สุด ทำให้ก้อยเข้าใจ เรียนรู้ วัฒนธรรมฝรั่งเศสและปรับตัวได้เร็วมาก ขอบคุณสวรรค์หรืออะไรก็ตามที่ทำให้ได้เจอ Leila เพราะถ้าไม่มี Leila ก็ไม้รู้ว่า การใช้ชีวิตที่นี่จะเป็นอย่างไร หากไม่ได้รับความช่วยเหลือ มิตรภาพ และการเป็นผู้ฟัง (ปรับทุกข์) ที่ดีของ Leila 
ขอขอบคุณ Bernadette ที่คอยช่วยเหลือ จัดหาวัสดุ อุปกรณ์ สารเคมีและมีบ่าให้ซบให้กอดในเวลาที่ต้องการ ขอบคุณ Alexandra, Claire, Monique สำหรับความช่วยเหลือและคอยเป็นห่วงเป็นใย ขอขอบคุณทีมวิจัย PAPC ทุกๆ ท่านที่คอยช่วยเหลือและให้กำลังใจ

ขอขอบคุณมิตรภาพอันแสนพิเศษ ความประทับใจ ความมีน้ำใจของ Laurent, Patricia Lempeurer, Patricia Lllorca, พี่รุ้ง Saiwaroon และครอบครัวที่น่ารักของรุ้ง

ขอขอบคุณ Adrien, Phillipe, Gary และเพื่อนๆ ที่ชมรมดำน้ำ Natil'UB สำหรับช่วงเวลาดีๆ ตอนเล่นแบดมินตัน และดำน้ำ ขอขอบพระคุณพี่จิ๋ม วณาพิศ และ พี่โป๋ จาตุรนต์ เฉิดเหรัญ อย่างสุดซึ้งสำหรับความช่วยเหลือ การดูแล ความ อบอุ่น ความสนุกสนาน ในทุกๆ ครั้งที่ไปอาศัยพึ่งพิง

ขอขอบคุณบรรดาพี่สาว น้องสาว (นอกสายเลือด) อันได้แก่ พี่นุช พี่อ้อม น้องตาล บรรดาเพื่อนๆ เนม ปอ Suly, Pascal, Bérangère เพื่อนๆ ทุกคนที่โรงเรียนสมุทรสาครบูรณะ เพื่อนๆ ชาว Neslté เพื่อนๆ พี่น้องเมือง Dresden, เพื่อนๆ Erasmus Mundus, เพื่อนๆ มหาวิทยาลัยสงขลานครินทร์ มหาวิทยาลัยมหิดล ศูนย์เครื่องมื่อกลางคณะวิทยาศาสตร์ มหิดล ที่คอยส่งกำลังใจ ความช่วยเหลือ คอยปลอบโยน ไม่ว่าจะทางใดก็ตาม (ส่วนตัว โทรศัพท์ อีเมล โซเชียลเน็ตเวิร์ค หรือทางอื่นๆ)

ขอขอบคุณครอบครัว Hasted และผองเพื่อน Anne, Keith, Alice, Cara, Will, Rich, Jude, Ezra, Ann, Ron, Di และ John สำหรับ ความรักที่ไม่มีพรมแดนและไม่สิ้นสุด ความเข้าใจ แรงหนุน แรงผลักดัน ความห่วงใย อ้อมกอด และ บ้านหลังที่ 2 ที่มีให้อย่างเสมอมาตั้งแต่ได้รู้จักกัน

ขอขอบพระคุณป้าจิ๊กที่ทำให้มีทุกวันนี้ คอยสั่งสอน อบรม เลี้ยงดู และมอบความรักที่ไม่เคยสิ้นสุด ขอบพระคุณ แม่ ความรักจากแม่ และการที่ทำให้ก้อยเป็นคนเข้มแข็ง สามารถแก้ปัญหาต่างๆ ได้ด้วยตัวเอง ไม่ท้อถอย ขอบคุณทุกคน ในครอบครัว ป้าจิ๊ก แม่ ลุงต้อย ลุงมาตร ลุงตี๋ ป้าแอ๊ด ป้าหมาย ป้าเล็ก น้องชายทั้งสอง (เก๋ กุ๊ก) ปุ้ย เตย พี่อ๊อก และ หลานๆ (ต้นข้าว ต้นกล้า ปิ่น) สำหรับความรักที่มีให้กัน ความเข้าใจ แรงสนับสนุน หยาดน้ำตา และพัสดุที่เต็มไปด้วย อาหารไทยทุกๆ $2-3$ เดือน

ขอขอบคุณ Jean-Christophe สำหรับการเป็นผู้ฟังที่ดี ความอดทน ความใจดี เอื้ออาทร ความช่วยเหลือที่มีให้ ขอบคุณที่คอยทำให้ก้อยใจเย็นลงได้เสมอๆ ขอบคุณสำหรับความเข้าใจ การดูแลเอาใจใสโดยเฉพาะช่วงเวลาที่เขียน วิทยานิพนธ์อันแสนเครียดและเวลาที่ยากลำบาก

ท้ายที่สุดก้อยขออุทิศวิทยานิพนธ์ระดับปริญญาเอกนี้ให้พ่ออันเป็นที่รัก ซึ่งเคยขอให้ก้อยเรียนแพทย์เมื่อสมัยยัง เด็กๆ “ถึงพ่อ ก้อยขอโทษที่ไม่ได้เรียนแพทย์อย่างที่พ่อขอ พอก้อยโตขึ้นความสนใจก้อยเปลี่ยนไป ก้อยสูญเสียแรงผลักดัน ก้อยไม่สามารถเป็น Dr. ทางการแพทย์ แต้ก้อยเป็น Dr. ทางวิทยาศาสตร์อาหารให้พ่อได้ อยากบอกว่ามันสนุกกว่ากัน เยอะเลย" ไม่ว่าพ่อจะอยู่ที่ไหน ขอให้รับรู้ว่า “ก้อยทำสำเร็จแล้ว" และ “ก้อยทำเพื่อพ่อ" “ก้อยรักพ่อนะ"

ขออภัยไว้ ณ ที่นี่หากไม่สามารถเอ่ยชื่อทุกท่านได้ หรือผิดพลาดประการใด ได้โปรดรับรู้ว่า ก้อยขอขอบคุณทุกๆ คนจากใจจริงสำหรับความอบอุ่น ความเอื้ออาทร กำลังใจ แรงสนับสนุน ความเป็นห่วงใยและความรักที่มีให้ น.ส. ศิลาวรรณ สมบูรณ์จันทร์ (ก้อย) 
The effect of hydrothermal treatments and flavours addition on starch structure and its physical properties were studied. Native wheat starch was treated at 2 different hydrations (water-starch ratios: 50/50 and 80/20 g w/w) and temperatures (65 and $85^{\circ} \mathrm{C}$ ) in the presence of flavours (ethyl hexanoate and 2-hexanone). The freshly prepared samples were subjected to DSC and flavour analysis. Flavour inclusion complex could not be detected by DSC, however the result of flavour analysis proved that there were flavours interactions with starch. Both ethyl hexanoate and 2-hexanone interacted with starch at similar rates. The highest flavour loss was found in the samples at high hydration and heated at $85{ }^{\circ} \mathrm{C}$. The loss of flavour was mainly due to vaporisation during hydrothermal treatments. After hydrothermal treatments, the samples subjected to freeze-drying and they showed flavour stability upon freeze-drying. The freeze-dried samples were subjected to various studies: DSC $\left(T_{g}\right)$, RVA, granule size, XRD, WAXS, SAXS and storage study. The hydrothermal treatments resulted in samples with different properties. At high hydration, temperature influenced granule size and pasting properties. The samples heated at $65{ }^{\circ} \mathrm{C}$ had significantly greater granule diameter, lower peak viscosity than samples heated at $85{ }^{\circ} \mathrm{C}$ and no significantly difference in \% crystallinity. At low hydration, heating temperature had no significantly influence on granule diameter but significantly affected pasting properties, \% crystallinity and SAXS profile. The samples heated at $65{ }^{\circ} \mathrm{C}$ had a greater peak viscosity, \% crystallinity and greater peak on SAXS than after a treatment at $85^{\circ} \mathrm{C}$. The residual flavour contenthad no significant influence on structure but affected pasting properties. Regarding storage study, the samples were stored at 58 and $75 \% \mathrm{RH}$ and withdrawn for SPME, flavour residual extraction and DSC (enthalpy of relaxation) at 2, 4 and 14 weeks of storage. The samples had greater flavour release at $75 \% \mathrm{RH}$ and ethyl hexanoate showed greater release than 2-hexanone. The samples showed increasing of enthalpy relaxation upon storage. 
L'effet des traitements hydrothermiques et l'effet des arômes sur la structure de l'amidon et de ses propriétés physiques ont été étudiés. L'amidon de blé natif a été traité à 2 hydratations différentes (rapports eau-amidon: 50/50 et 80/20 g/g) et à 2 températures (65 et $85^{\circ} \mathrm{C}$ ) en présence d' arômes (hexanoate d'éthyle et de 2-hexanone). Les échantillons fraîchement préparés ont été soumis à l'analyse calorimétrique (AED) et au dosage d' arôme. Aucun complexe d'inclusion entre amidon et arôme n'a pu êtredétecté par AED cependant le résultat de l'analyse aromatique a prouvé qu'il y avait des interactions arômeamidon. Les deux composés d'arôme (hexanoate d'éthyle et 2-hexanone) ont interagi avec l'amidon à des teneurs comparables. Les pertes d'arômes ont été trouvées les plus élevées dans les échantillons traités aux plus hautes hydratation et température . La perte d'arôme était principalement liée à l'évaporation lors des traitements hydrothermiques. Après les traitements hydrothermiques, les échantillons ont étélyophilisés ont montré une stabilité d'arôme à la lyophilisation. Les échantillons lyophilisés ont été soumis à diverses études: DSC (Tg), RVA, la taille des granules, XRD, WAXS, SAXS étude et de stockage. Les traitements hydrothermiques ont conduit à des échantillons avec des propriétés différentes. A haute hydratation, la température influence la taille des granules et des propriétés rhéologiques à la cuisson (pasting). Les échantillons chauffés à $65{ }^{\circ} \mathrm{C}$ présentaient des tailles de granules significativement plus importantes, une viscosité maximale (en RVA) inférieure à celles des échantillons chauffés à $85{ }^{\circ} \mathrm{C}$ mais de significative différence en $\%$ de cristallinité. A faible hydratation, la température de chauffage n'avait pas d'influencer significative sur la taille des granules, mais un effet significatif sur les propriétés rhéologiques à la cuisson, le degré de cristallinité et le profil SAXS. Les échantillons chauffés à $65{ }^{\circ} \mathrm{C}$ avaient une viscosité maximale supérieure, un degré de cristallinité plus élevé et des pics SAXS plus importants qu'après un chauffage à $85^{\circ} \mathrm{C}$. La teneur résiduelle en arôme n'a eu aucune influence significative sur la structure, mais semble affecter les propriétés rhéologiques à la cuisson. En ce qui concerne l'étude à la conservations, les échantillons ont été stockés à 58 et $75 \%$ d'humidité relative et étudiés par analyse SPME, par extraction d'arôme et par AED pour un suivide relaxation d'enthalpie après de 2, 4 et 14 semaines de stockage. Les échantillons avaient une plus grande libération de l'arôme à $75 \%$ HR et l'hexanoate d'éthyle montré une plus grande libération de 2-hexanone. Les échantillons ont montré une augmentation de relaxation d'enthalpie de lors d'un stockage. 


\section{Contents}

Acknowledgement

Abstract

Résumé

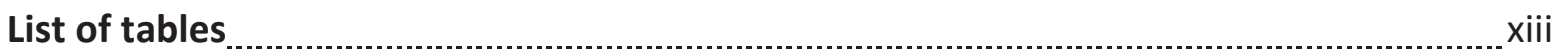

List of figures

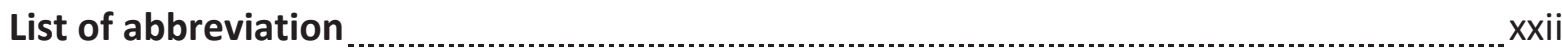

\section{Chapter 1: Introduction}

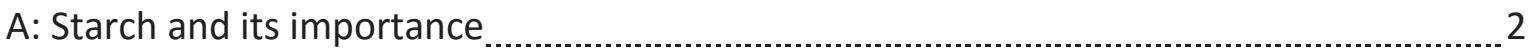

B: Sources and applications of starch for industry $\ldots$

C: Starch-based food products and glassy state .............................................................. 4

D: Application of starch interactions

Flavour encapsulation aspect

Nutritional aspect

\section{Chapter 2: Literature review}

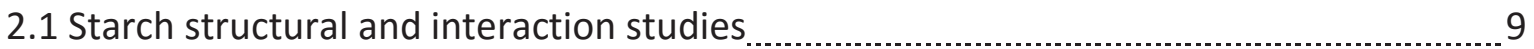

2.1.1 Chemistry and structure

2.1.2 Starch and hydrothermal treatment

2.1.2.1 Gelatinisation and phase transition upon hydrothermal treatment ........18

2.1.2.2 Heat-moisture

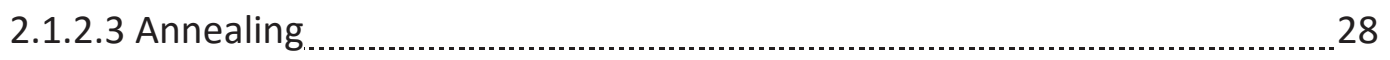

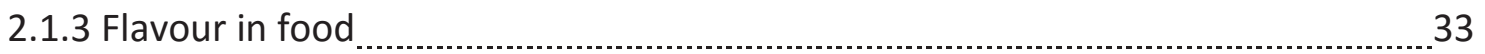

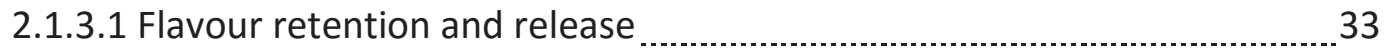

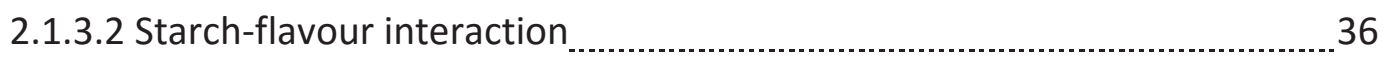

2.1.3.2.1 Interaction between flavour and granular starch _................... 36

2.1.3.2.2 Interaction between flavour and starch under hydrothermal treatment

2.1.4 Study of starch structure and interaction and study techniques ........................... 43

2.1.4.1 Granular level: granulometry

2.1.4.2 Molecular level: Carbohydrate spectroscopy ............................................ 49

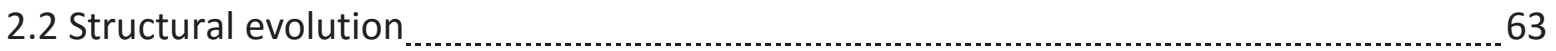


2.2.1 Glass transition: a key parameter 64

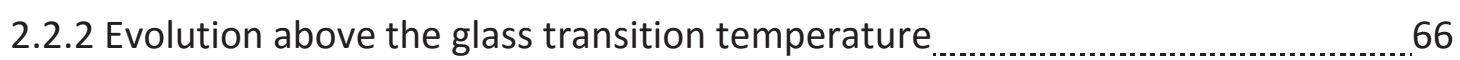

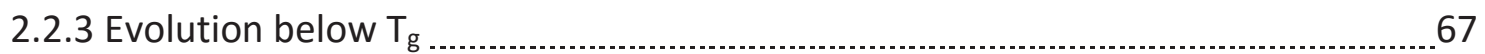

Objectives and Rational

\section{Chapter 3: Materials and methods}

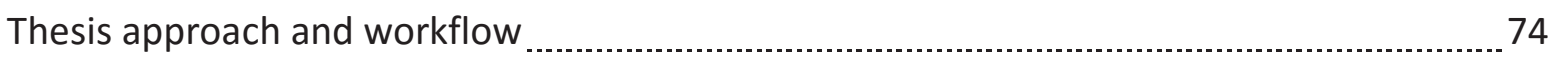

3.1 Materials 75

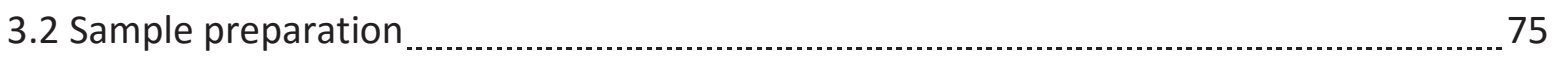

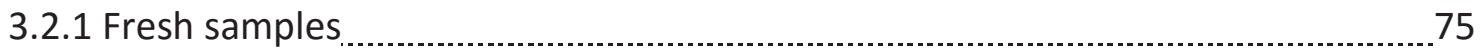

3.2.2 Freeze-dried samples

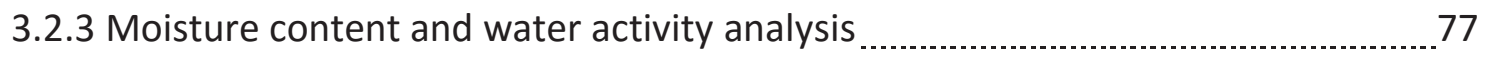

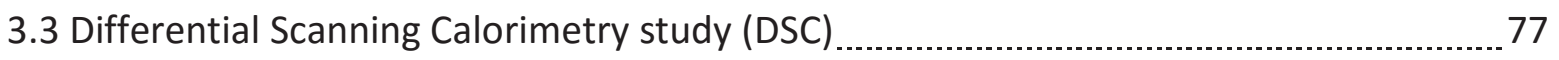

3.4 Flavour analysis

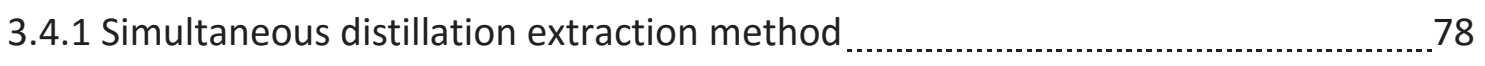

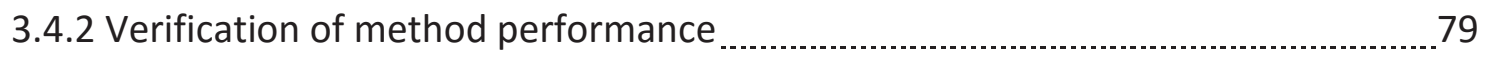

3.4.2.1 Linearity

3.4.2.2 Recovery of extraction and matrix influence

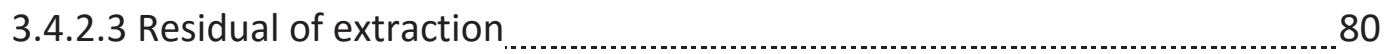

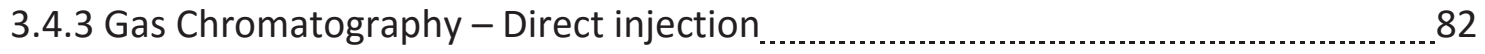

3.5 Storage study

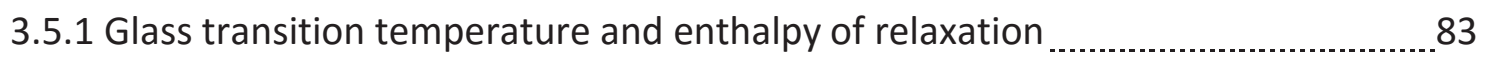

3.5.2 Analysis of flavour retention and release upon storage by headspace

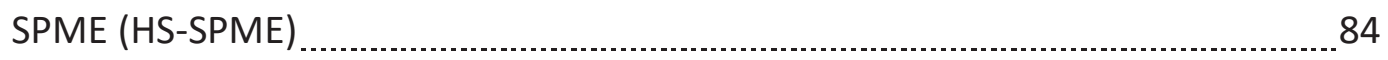

3.6 Starch pasting profile study 85

3.7 Granule size study.

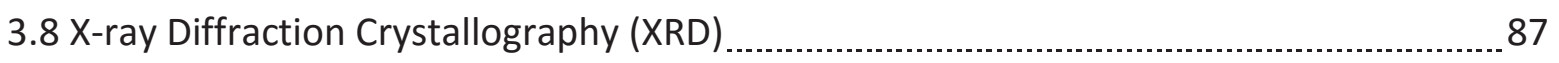

3.9 Wide Angle X-ray Scattering (WAXS) and Small Angle X-ray Scattering (SAXS) ............... 88

3.9.1 Wide Angle X-ray Scattering (WAXS)

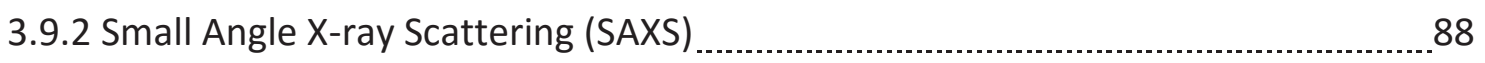

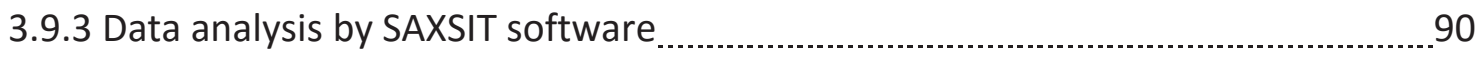


3.10 Fourier transform infrared spectroscopy (FTIR) 90

3.11 Statistical analysis 91

\section{Chapter 4: Results and discussion}

4.1 Effect of hydrothermal treatment. 93

4.1.1 Flavour residual content upon hydrothermal treatment. 93

4.1.2 DSC measurement of semi-crystalline sample and residual native starch....... 95

4.1.3 DSC measurement of heat-treated samples 100

4.1.4 Pasting profile 107

4.1.5 Structural analysis 114

4.1.5.1 Granule study size 114

4.1.5.2 X-ray diffraction (XRD) and Wide angle X-ray scattering (WAXS). 122

4.1.5.3 Small angle X-ray scattering (SAXS). 131

4.2 Storage study 139

4.2.1 Stability of flavour upon storage 139

4.2.1.1 Flavour release study by Static Headspace-Solid Phase Micro

Extraction (SH-SPME) 139

4.2.1.2 Flavour retention study by simultaneous distillation extraction (Likens-Nickerson extraction). 145

4.2.2 Structural evolution upon storage (enthalpy of relaxation) 149

4.3 Structural and flavour analysis by FTIR (Trial approach). 154

\section{Chapter 5 : General discussion}

5.1 Effect of hydrothermal treatment. 159

5.1.1 Flavour interaction. 159

5.1.2 Rheology and structure (Granular and sub-granular levels). 160

5.2 Starch-flavour interaction versus physical state. 163

5.2.1 Flavour retention and release 163

5.2.2 Structural relaxation. 164 


\section{Contents}

Chapter 6: Conclusions and perspectives

Findings

Perspectives and improvements

Application of this study

Chapter 7: Résumé substantiel

Introduction 173

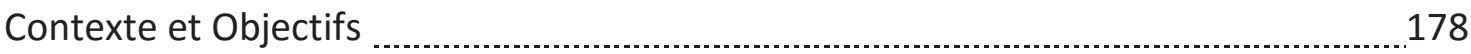

Résultats et Discussion générale

Conclusion

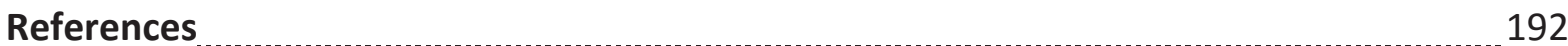

Appendix

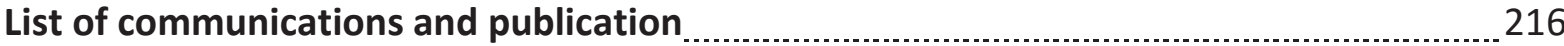




\section{Chapter 2: Literature review}

Table 2-1: Advantages and disadvantages of different granule size determination techniques (Lindeboom, et al., 2004) 48

Table 2-2: Wavelength regions, spectroscopy methods, and associated transition (Penner, 2010) 50

\section{Chapter 3: Materials and methods}

Table 3-1: Physicochemical properties of flavour compounds 75

Table 3-2: Samples description 76

\section{Chapter 4: Results and discussion}

Table 4-1: Amount of residual flavour in fresh sample in $\mathrm{mg} / \mathrm{g}$ of dry weight average value from 3 sample preparations 94

Table 4-2: Amount of residual flavour in freeze-dried samples in $\mathrm{mg} / \mathrm{g}$ of dry weight average value from 3 sample preparations 95

Table 4-3: DSC thermal properties and residual of native starch in starch paste 101

Table 4-4: RVA Pasting properties in comparison between sample treatment (recipe, cooking temperature and flavour addition)

Table 4-5: The particle size parameters 120

Table 4-6: Degree of relative crystallinity by XRD analysis 127

Table 4-7: SAXS Fitting parameters 136

Table 4-8: Ethyl hexanoate residual by Likens-Nickerson extraction after storage at $58 \% \mathrm{RH}$ 145

Table 4-9: Ethyl hexanoate residual by Likens-Nickerson extraction after storage at $75 \% \mathrm{RH}$ 146

Table 4-10: 2-Hexanone residual by Likens-Nickerson extraction after storage at $58 \% \mathrm{RH}$ 146

Table 4-11: 2-Hexanone residual by Likens-Nickerson extraction after storage at $75 \% \mathrm{RH}$ 147

\section{Chapter 5: General discussion}

Table 5-1: Summary of key results 166 
Chapter 7: Résumé substantiel

Tableau 7-1: Résumé des résultats principaux 187

\section{Annex}

Table A-1: Residual of flavour (after purging and after one night equilibration) and retained flavour in saturated salt after 14 weeks storage 214

Table A-2: Glass transition temperature and moisture contents during storage 215 


\section{Chapter 2: Literature review}

Figure 2-1: Basic structural motifs of amylose and amylopectin, along with the labelling of the atoms and torsion angles. Extension of the basic motifs to macromolecular structures (Pérez \& Bertoft, 2010).

Figure 2-2: Crystalline packing of double helices in A-type (A) and B-type (B). Projection of the structure onto the (a, b) plane (Pérez \& Bertoft, 2010).

Figure 2-3: Schematic of normal blocklet structure in starch granule (Tang, et al., 2006)... 12

Figure 2-4: WAXS profile calculation based on coexistence of monoclinic and hexagonal crystals in weight ratio of 4:1. A-type crystal (purple line), B-type crystal (blue line) and curve-fitting residual (dotted line) (H-K. Huang et al., 2014). 12

Figure 2-5: Schematic representation of X-ray diffraction patterns of various starches used for their classification into A-, B-, C-, and V-type starches (Roos, 1995; Zobel, Young, \& Rocca, 1988).

Figure 2-6: Starch granule in cross section showing the orientation of amylopectin double helices in the crystalline lamellae (Waigh, et al., 1997).

Figure 2-7: Overview of starch granule (Gallant, et al., 1997) 16

Figure 2-8: Heat-moisture treatment of starch versus water content and temperature in starch (Biliaderis, 2009)

Figure 2-9: Melting process of the semi-crystalline lamellae. Schematically shown (left) are stacked lamellae of well packed crystalline nanoclusters of amylopectin (blue) and amylose (red) chains. Melting of defect-rich regions leads to partial loss of integrity of the lamellae, into layers alternating rich and poor in tilted disordered nanoclusters (shaded background in blue), as shown in the middle. The process ends with disperse and molten nanoclusters (bright blue) of amylopectin loosely associated with relatively untangled linear amylose chains (right) (H-K. Huang, et al., 2014).

Figure 2-10: A schematic representation of DSC thermograms typical of starch when heated with various amounts of water (Roos, 1995).

Figure 2-11: Schematic diagram of starch granule structure - representation 3 phase component: crystalline, intercrystalline amorphous and bulk amorphous components (Ratnayake, et al., 2008). 
Figure 2-12: Gelatinisation for disperse linear amylose chains and ellipsoidal nanoclusters of amylopectin, of dimension ca $7 \times 3 \times 3 \mathrm{~nm}$ (left); gelation for loosely fractal-structured networks on a micrometer scale (right) (H-K. Huang, et al., 2014). 25

Figure 2-13: Mechanism of annealing (Jayakody \& Hoover, 2008)

Figure 2-14: Schematic diagram of state and phase transition of starch, note the effect of moisture content and time on the various stages. $T_{\mathrm{g}} 1, \mathrm{~T}_{\mathrm{g}} 2$, and $\mathrm{T}_{\mathrm{g}} 3$ represent the glass transition at different moisture content levels. A-L and V-structures denote short- and long-range order of amylose-lipid complexes, whereas d.h. (double helices) order corresponds to short-range B-type structures (Biliaderis, 2009).

Figure 2-15: Flavour-food interaction diagram (Preininger, 2006) 34

Figure 2-16: Molecular modelling representation of amylose-fatty acid complexes showing the inclusion of the aliphatic part (C12) of fatty acid inside the hydrophobic cavity of the amylose single helix (Buléon, et al., 1998). 39

Figure 2-17: Schematic representation of the structure of amylose-aroma complexes and possible location of the molecules trapped in the amorphous phase (Biais, Le Bail, Robert, Pontoire, \& Buléon, 2006). 40

Figure 2-18: X-ray diffractograms obtained from crystals of amylose with isoamyl acetate (a), linalool (b) and ethyl hexanoate (c) (Arvisenet, et al., 2002). 41

Figure 2-19: Pictorial representation of the length scales within the starch granule together with techniques used to characterise the structural features (Tester \& Debon, 2000) 45

Figure 2-20: Illustration of the concept of equivalent spheres (Anonymous, 2012) 46

Figure 2-21: Examples of starch granule micrographs from various microscopy techniques; a) \& b) LM and PLM of native potato starch after hydrothermal treatment (magnifying 400 X) (Vermeylen, Goderis, \& Delcour, 2006), c) CLSM optical cross-section of A-type granules of waxy soft wheat starch isolated via traditional schemes - arrows pointed at granule channels (Kim \& Huber, 2008), d) SEM of unfractionated wheat starch (Sunco variety) (Salman et al., 2009), e) TEM of native wheat starch (Sujka \& Jamroz, 2013). 46 
Figure 2-22: Bragg's diffraction (Paulus \& Gieren, 2001)

Figure 2-23: The range of elastic scattering techniques, corresponding size range and complementary methods shown in relation to the hierarchical structure of starch; $n$ = neutron; $\mathrm{e}=$ electron; $\mathrm{nR} / \mathrm{XRR}=$ neutron and $\mathrm{X}$-ray reflectometry, TEM = transmission electron microscopy; USANS/USAXS = ultra-SANS/SAXS (Blazek \& Gilbert, 2011; Lopez-Rubio \& Gilbert, 2009). 53

Figure 2-24: X-ray diffraction diagrams of A-, B- and Vh-type starch (Buléon, et al., 1998) 54

Figure 2-25: Scattering pattern from regular maize starch and corresponding SAXS curve showing relative intensity vs. scattering vector (Blazek \& Gilbert, 2011). 55

Figure 2-26: Integrated SAXS-WAXS data measured for native tapioca in excess water. The arrows indicate the lamellar peaks at $q=0.065$ and $0.13 \AA^{-1}$, the $(100)_{H}$ reflection at $q=0.40 \AA^{-1}$ of hexagonal (B-type) crystals, and the characteristic twin peaks near $1.3 \AA^{-1}$ of the monoclinic (A-type) crystal. SAXS data are fitted with the model comprising either arrayed elliptic plates (dotted curve) or disk plates (solid curve) (H-K. Huang, et al., 2014).......55

Figure 2-27: The two-stage process involved in the gelatinisation of starch in limiting water. Two different processes are shown for A and B type starches. It is proposed that the intermediate phase is determined by the length of amylopectin helices. Relative values of the orientational $(\Phi)$, lamellar $(\Psi)$ and helical order parameter (h) are included. (i) In B-type starch the intermediate phase is nematic in character, (ii) and in A-type starch the intermediate phase is isotropic in character (Waigh, Gidley, et al., 2000).

Figure 2-28: Infrared spectra of starch from various botanical origins

(Y. Sun, et al., 2014) 60

Figure 2-29: FT-IR spectra of amylose (a), complexed with decanoic acid (b), with hexanoic acid (c) and with 1,5-decanolactone (d) (Biais, et al., 2006).

Figure 2-30: The different level of structural organisation (Pérez \& Bertoft, 2010). 62

Figure 2-31: Mechanism of starch phase transition versus temperature (Buléon, 1990)....63

Figure 2-32: Plot of the variation of the glass transition temperature $\left(T_{g}\right)$ versus moisture content in native and pregelatinised wheat starch 
(Zeleznak \& Hoseney, 1987).

Figure 2-33: Evolution of thermodynamic properties (free volume, enthalpy and entropy) versus temperature (Roos, 2007). 67

Figure 2-34: Change in physical properties at the glass-liquid transition (Champion, et al., 2000)

\section{Chapter 3: Materials and methods}

Figure 3-1: Schematic of sample preparation and analysis 74

Figure 3-2: Simultaneous distillation extraction method 81

Figure 3-3: Schematic representation of the storage experimentation 83

Figure 3-4: Typical complete RVA curve, showing the main parameters used to describe pasting (Batey, 2007). 86

Figure 3-5: Illustration of the Dv10, Dv50 and Dv90 on a typical particle size distribution where significant proportion of fines are present (Anonymous, 2012)

Figure 3-6: Change in the SAXS intensity profile of a $45 \%$ starch slurry held at $51{ }^{\circ} \mathrm{C}$.

The data are binned at 5 min intervals from bottom (room temperature) to top (longest annealing time) (Cameron \& Donald, 1992). 89

\section{Chapter 4: Results and discussion}

Figure 4-1: Extracted flavour after cooking as percent of initial 94

Figure 4-2: DSC thermograms of first heating scan of native wheat starch at $80 / 20(\mathrm{~A})$ and 50/50 (C) water/starch wet weight ratio without aroma compounds (a), with ethyl hexanoate (b), with 2-hexanone C1 (c) and with 2-hexanone C2....99

Figure 4-3: DSC thermograms of first scan of freshly cooked samples (starch paste):

No Flavour (a), with Ethyl hexanoate (b), with 2-Hexanone C1 (c),

2-Hexanone C2 (d). 100

Figure 4-4: DSC thermograms (second scan) for glass transition $\left(T_{g}\right)$ analysis of freeze-dried sample after freeze-drying (a)-(d) and after freeze drying and equilibrium at 75\% RH, respectively. A65, A85, C65 and C85 (e)-(h), respectively. 103

Figure 4-5: Glass transition temperature $\left(T_{g}\right)$ versus moisture 104 
Figure 4-6: Glass transition temperature $\left(T_{g}\right)$ versus percent relative crystallinity at $58 \% \mathrm{RH}(\mathrm{a}), 75 \% \mathrm{RH}(\mathrm{b})$ 105

Figure 4-7a-b: RVA pasting profiles of freeze-dried starch in comparison on flavour addition and treatment temperature. 110

Figure 4-8: Principle component analysis (PCA) on RVA pasting profile 113

Figure 4-9a-d: Volume distribution of freeze-dried sample in comparing within recipe:

A65 (a), A85 (b), C65 (c), and C85 (d)

Figure 4-10a-d: Volume distribution of freeze-dried sample in comparison on flavour addition: without flavour (a), with ethyl hexanoate (b), with 2-hexanone C1 (c), with 2-hexanone C2 (d) 119

Figure 4-11: Particle size "volume weighted mean, $D[4,3]$ "

Figure 4-12: Coordination plot between granule size distribution (D[4,3]) and RVA (Peak viscosity)

Figure 4-13a-b: Diffractograms by XRD analysis - A65 and A85 samples (a) and C65 and C85 samples (b) compared to native starch

Figure 4-14a-j: WAXS scattering profiles and diffractograms - Native wheat starch (a), Pre-gelatinised (b), A65 (c), A65EH (d), A85 (e), A85EH (f), A85Hex C1 (g), A85Hex C2 (h), C65 (i), C65EH (j) 125

Figure 4-14k-p: WAXS scattering profiles and diffractograms - $\mathrm{C} 65 \mathrm{HexC} 1(\mathrm{k})$,

C65Hex C2 (I), C85 (m), C85EH (n), C85Hex C1 (o), C85Hex C2 (p). 126

Figure 4-15a-c: Calculation of \%relative crystallinity in WAXS study by curve-fitting: Blue lines represent pre-gelatinised starch (which has been used as curve-fitting baseline), red lines native starch (a), A85 (b), C85Hex C2 (C), respectively. 127

Figure 4-16a-d: WAXS profiles in comparison per heating temperature, hydration and flavour addition - A65s (a), A85s (b), C65s (c) and C85s (d). Arrows indicate characteristic peaks corresponding to $V_{h} \operatorname{complex}\left(2 \theta: 7.4^{\circ}, 12.7^{\circ}\right.$ and $\left.19.8^{\circ}\right)$. 128

Figure 4-17: Relative intensity versus thickness of crystalline-amorphous layers "d-spacing" of native wheat starch 133

Figure 4-18a-c: SAXS Scattering profiles: control samples (a), A65s (b), A85s (c), C65 (d) and C85 (e). Arrows indicate scattering peaks. 135 
Figure 4-19: Linear-fit of SAXS scattering profile - $\log ($ Intensity) versus $\log (q)$ :

Optimal-fit of pre-gelatinised starch (a), adjusted-fit of A85 (b). 136

Figure 4-20a-e: SAXS Scattering profiles in log-log scale plot: control sample (a), A65s (b),

A85s(c), C65 (d), and C85 (e). Arrows indicate scattering peaks.

Figure 4-21a-b: Comparison of SPME vapour/solid ratio of samples after storage

(a: $58 \% \mathrm{RH}$ and b: $75 \% \mathrm{RH}$ ).

Figure 4-22a-b: Comparison of SPME vapour/solid ratio of ethyl hexanoate release

after storage 14 weeks, after purge and in saturated salt solution.

Figure 4-23a-b: Schematic represents flavour release and molecular mobility upon

storage of ethyl hexanoate at $75 \% \mathrm{RH}(\mathrm{a})$, ethyl hexanoate at $58 \% \mathrm{RH}(\mathrm{b})$

and 2-hexanone at 75 and $58 \% \mathrm{RH}$ (c).

Figure 4-24: DSC thermograms ( $1^{\text {st }}$ and $2^{\text {nd }}$ scan) of sample $A 85$ after storage at $75 \% \mathrm{RH}$ for $0,2,4$ and 14 weeks.

Figure 4-25: Enthalpy of relaxation upon storage at $58 \%$ and $75 \% \mathrm{RH}-\mathrm{A} 65$ sample (a), A85 samples (b), C65 samples (c), and C85 samples (d)

Figure 4-26a-d: FTIR Spectra and derivative spectra of A65 samples (a) and (c) and A85 sample (b) and (d) in comparison with native, pre-gelatinised and amylose from corn starch

Figure 4-27a-d: FTIR Spectra and derivative spectra of C65 samples (a) and (c) and C85 sample (b) and (d) in comparison with native, pre-gelatinised and amylose from corn starch.

\section{Chapter 5 : General discussion}

Figure 5-1: Principle component analysis on peak viscosity, granule size, \% residual native, $\%$ crystallinity and \% flavour residual of samples with flavour addition. 167

\section{Chapter 7: Résumé substantiel}

Figure 7-1: Analyse en composantes principales sur le pic de viscosité, granulométrie, $\%$ résiduelle d'amidon natif, \% cristallinité et \% d'arôme résiduelle dans des échantillons avec arôme. 188 


\section{Appendix}

Figure A-1: Extracted amount of ethyl hexanoate by SPME in $\mu g$ unit 212

Figure A-2: Extracted amount of 2-hexanone by SPME in $\mu g$ unit 212

Figure A-3: Comparision of SPME vapour/solid ratio of samples after storage. 213

Figure A-4: Comparison of SPME vapour/solid ratio of 2-hexanone released after storage 14 weeks, after purge and in saturated salt solution 


\begin{tabular}{|c|c|}
\hline$\%$ & Percent \\
\hline${ }^{\circ} \mathrm{C}$ & Degree celcius \\
\hline$\circ$ & Angle degree \\
\hline $2 \theta$ & Angle (diffraction/scattering) \\
\hline$\sim$ & Approximate/Approximately \\
\hline et al. & Et all (Latin), and others \\
\hline i.e. & Id est (Latin), that is \\
\hline e.g. & Example gratia (Latin), for example \\
\hline g & Gram \\
\hline $\mathrm{mg}$ & Milligram \\
\hline ng & Nanogram \\
\hline$\mu g$ & Microgram \\
\hline 1 & Litre \\
\hline $\mathrm{ml}$ & Millilitre \\
\hline$\mu l$ & Microlitre \\
\hline $\mathrm{m}$ & Metre \\
\hline $\mathrm{cm}$ & Centimetre \\
\hline $\mathrm{mm}$ & Millimetre \\
\hline$\mu \mathrm{m}$ & Micrometre \\
\hline$\AA$ & Angstrom unit \\
\hline i.d. & Internal diameter \\
\hline $\min$ & Minute \\
\hline s & Second \\
\hline $\mathrm{h}$ & Hour \\
\hline$g / l$ & Gram per litre \\
\hline DE & Dextrose equivalent \\
\hline $\mathrm{RH}$ & Relative humidity \\
\hline $\mathrm{T}_{\mathrm{c}}$ & Conclusion temperature \\
\hline $\mathrm{T}_{\mathrm{g}}$ & Glass transition temperature \\
\hline $\mathrm{T}_{\mathrm{m}}$ & Melting temperature \\
\hline$T_{0}$ & Onset temperature \\
\hline
\end{tabular}




\begin{tabular}{ll}
\hline JH & Enthalpy \\
Cp & Jule \\
cP & Heat capacity \\
psi & RVA viscosity unit \\
W/w & Pounds per square inch \\
DSC & Weight by weight \\
FT-IR & Differential scanning calorimetry \\
GC & Fourier Transform Infrared (FTIR) Spectroscopy \\
FID & Gas Chromatography \\
RVA & Flame lonisation Detection \\
XRD & Rapid Visco Analyser \\
WAXS & X-ray Diffraction \\
SAXS & Wide-Angle X-ray Scattering \\
SANS & Small Angle X-ray Scattering \\
SPME & Small Angle Nutron Scattering \\
EH & Solid Phase Micro Extraction \\
Hex & Ehtyl hexanoate \\
ANOVA & 2-Hexanone \\
PCA & Analysis of variance \\
SD & Principal Component Analysis \\
& Standard Diviation \\
\hline
\end{tabular}


Chapter 1: Introduction 


\section{A: Starch and its importance}

Starch is a valuable macromolecule and the second-most abundant natural biomaterial, next to cellulose (Sablani, Kasapis, \& Rahman, 2007). It serves as an inexpensive energy source compared to other macromolecules. Regarding human energy intake, carbohydrates contribute approximately to $40-50 \%$ of human energy intake which derives from $4 \mathrm{kcal} / \mathrm{g}(17 \mathrm{~kJ} / \mathrm{g}$ ) (Biliaderis, 1991; FAO, 1998). Among all sources of energy intake, starch is the most important (FAO, 1998). Starch has been consumed as a staple food since ancient times (Schwartz \& Whistler, 2009). The function and usage of starch are not only to stop hunger and fulfil nutrition requirement, but also to improve taste and modify food texture. The differences of crispiness, roughness, softness and viscosity are a result of different amounts of starch present in the food. The abundance, accessibility together with unique properties and structure make the applications of starch to be various. Starch utilisation is diversified from simple household cooking throughout structural modification for flavour encapsulation, thickening, pharmaceutical, film, packaging, thermoplastic applications, etc...(Kaur, Ariffin, Bhat, \& Karim, 2012). Starch is a biopolymer from plants, hence it is easily to produce. Therefore, attention has also been paid to a conversion of starch into an alternate fuel source.

The variety of starch usage brings its production worldwide to an enormous scale of. Research on starch is also focused on development of production processes and techniques in order to obtain the desired functions, properties and highest yield. When starch is used as a raw material in food manufacturing, the outcome of starch research findings helps increase quality and functionality of the final products. For example, starch and flour are graded according to their protein and amylose contents for a specific purpose on pastry, baking, noodle and cereal industries. Hydrolysis has been applied to starch. This leads to several types of sugar syrup, depending on dextrose equivalent number (DE number). The advancement of structural study and structural modification technologies facilitate particle size minimisation. Flavour encapsulation matrices (Ades, Kesselman, Ungar, \& Shimoni, 2012) and drug binding bed (Rahmouni, Chouinard, Nekka, Lenaerts, \& Leroux, 2001; Zimonja \& Svihus, 2009) are the outstanding examples of benefit from structural modification and particle size minimisation. Structural study has become more important since it is key to understand physical and chemical properties and elucidate interactions in the matrices, which starch is incorporated into. 


\section{B: Sources and applications of starch for industry}

The major types of starch commonly found and generally used in the household and industrial applications are corn, cassava, wheat, and potato. However, rice, sago, buckwheat, sweet, barley, arrowroot, are also important sources of starch (Ratnayake, Jackson, \& Steve, 2008). 60 million tonnes of starch are approximately produced annually worldwide (Copeland, Blazek, Salman, \& Tang, 2009; International Starch Institute, 2012; Zuckerforschung Tulln, 2012) .

Starch is mainly utilised in food products $60 \%$ and non-food purposes approximately $40 \%$ (Copeland, et al., 2009). Regarding $40 \%$ of non-food purposes, they consist of agriculture (animal feed and seed coating), pharmaceutical production (tablet and dusting powder), biodegradable plastic, textile (warp, fabrics, and yarns), paper (corrugated board, cardboard paper), and construction materials and others (mineral fibre, gypsum board, concrete, oil drilling, water treatment and glue) (Burrell, 2003; Calvert, 1997; Rahmouni, et al., 2001; Sajilata \& Singhal, 2005; Singh, Kaur, \& McCarthy, 2007).

Native starch is ideal as texture stabiliser and regulator in food systems while modified starch is generated to overcome the limitations of native starch for example low shear and thermal resistance, and highly cohesive texture (Mason, 2009; Singh, et al., 2007). The form, function and application of starch in food are versatile and depend on its structure and physical or chemical properties.

The unique structure and chemistry of starch granules allow it to perform several functions. Granular swelling elaborates thickening in soup, sauce and pie filling (Jang \& Pyun, 1996). When food processing involves thermal treatments, starch helps stabilise canned and frozen food. Gelatinised starch gives body and mouth feels to the food.

Starches, particular highly cross-linked, are stable at low $\mathrm{pH}$, high temperature and under shear force, therefore they are applied in sauce and salad dressings (Mason, 2009). Using starch as an encapsulation matrix reduces loss of volatiles compounds and oxidation of the fragile substance during storage (Ades, et al., 2012). Considering low moisture foods e.g. breakfast cereal, fried and baked snack, amylose content is a crucial factor for crispness, short texture, expansion and frying tolerance: the higher the amylose content, the greater the crispiness and stability. Glass transition and structural alteration occur during dehydration processes, resulting in brittleness of the product (Roudaut, Dacremont, Vallès 
Pàmies, Colas, \& Le Meste, 2002). Using starch as glazing contributes not only to surface shininess and attractiveness but also to the prevention of moisture attack of the product.

\section{C: Starch-based food products and glassy state}

The increasing world population leads to an increasing of food demand and consumption. In order to serve such growing food demand, food production has to scale up from household to industrial level or rely on manufacturing process. Starch-based products are among the most consumed worldwide and served as staple food or main source of energy. Starch has the unique chemical, physical and nutritional properties (BeMiller \& Whistler, 1996). In most of starch-processing, hydrothermal treatments are applied through baking, extrusion, etc. Hydrothermal treatments promote a loss of native crystallinity and result in a digestible substrate (BeMiller \& Whistler, 1996; Kasapis, 2012; Le Meste, Champion, Roudaut, Blond, \& Simatos, 2002). The resultant starches after hydrothermal treatment are usually poorly stable due to their humidity which can cause both microbial spoilage and recrystallisation (e.g. causing loss of softness in breads or cakes, hardening of fresh noodles...).

Dehydration is associated to many processes applied to starch based products: either through oven drying or extrusion cooking or freeze drying, spray drying, and roller drying... with the same goal: to reduce the water content of the food matrix and modify the texture of baked foods such as biscuits, cookies etc. Apart from texture modification, there are two benefits of dehydration. One is the stabilisation of products against the microbiological risk and another is slowing down of the possible evolution of physical properties of the material through a decrease of the molecular mobility. As a result of the dehydration of rubbery material, the matrix is immobilised in the glassy state. Such a freezing of the molecular motions is associated with the glass transition. The immobilisation has been reported to help preserve the food and avoid deterioration of nutrients, organoleptic properties, taste and flavour (Bhandari \& Howes, 1999; Jiranuntakul, Puttanlek, Rungsardthong, Punchaarnon, \& Uttapap, 2011; Le Meste, et al., 2002). Typically, the quality and flavour strength of food products can decrease during storage. This problem is related to changes in flavour compounds by physical and chemical processes (Ubbink \& Krüger, 2006). Immobilising flavour within glassy starch and lowering its water activity help preserving the flavour (Ubbink \& Krüger, 2006). 


\section{D: Application of starch interactions}

\section{Flavour encapsulation aspect}

Flavour is very important to food developers as it generates variety of foodstuffs and impacts consumer perception. The approaches of development are either to generate novel flavour or to preserve the original flavour in the food, which can be altered during food processing or storage (Busso Casati, Schebor, Zamora, \& Chirife, 2007). Moreover, flavour molecules themselves easily undergo oxidation, resulting in reduced flavour strength or offflavour development (Murua-Pagola, Beristain-Guevara, \& Martinez-Bustos, 2009). Encapsulation enables flavour restoration or protection by converting liquid flavour into a dry and free-flowing glassy powder, providing a protective barrier to flavour from undesirable environment. Encapsulation also facilitates controlling of flavour release as well as delivery of other active ingredients to specific target (Busso Casati, et al., 2007; MuruaPagola, et al., 2009; Zasypkin \& Porzio, 2004). The complexity of food matrices require a thorough understanding of the physical and chemical phenomena determining stability, release, perception and digestion to ensure a successful use of encapsulation (Ubbink \& Krüger, 2006).

Starch is able to form flavour-inclusion complex with certain flavours via gelatinisation (e.g. ethyl hexanoate, linalool) (Arvisenet, Le Bail, Voilley, \& Cayot, 2002). Flavour compounds bind to starch via non-covalent interactions in the helical cavity of amylose (Buléon, Colonna, Planchot, \& Ball, 1998; Conde-Petit, Escher, \& Nuessli, 2006). Starchflavour interactions, particularly inclusion complex fascinates the researchers in the field of flavour encapsulation. This is due to the structure of single amylose helix and cyclodextrins, which are suitable to encapsulate hydrophobic flavour compounds (Conde-Petit, et al., 2006; Hau, Gray, \& Taylor, 1998). It was found that starch-based matrices give better aroma retention than other texturising agents. The inclusion complex is believed to form upon gelatinisation and to provide protection during processing particularly storage(Hau, et al., 1998; Heinemann, Conde-Petit, Nuessli, \& Escher, 2001; Nuessli, Sigg, Conde-Petit, \& Escher, 1997).

There are numerous developments in encapsulation technologies by encapsulating active food ingredients in a variety of food-grade materials including glassy carbohydrates and biopolymer complexes (Ubbink \& Krüger, 2006). Glassy carbohydrate encapsulation systems are effectively reducing the flavour release rate during storage, and minimising 
oxidation rate because the diffusion of guest molecules through the glassy carbohydrate matrix is very slow (Ubbink \& Krüger, 2006). Starch granule morphology is involved in minimising the rate of flavour release or rate of oxygen uptake: a larger and less porous granular structure is the key for lowering effective transport rates (Ubbink \& Krüger, 2006).

The glass transition concept is critically important for amorphous carbohydrates. Glassy and rubbery states of a material can be distinguished through their position with regards to glass transition temperature $\left(T_{g}\right)$ (Angell, 1996). In rubbery state, starch structure is still able to evolve while molecular mobility is limited under glassy state (Ubbink \& Krüger, 2006). The glass transition temperature designates the critical temperature where molecular mobility degree changes. $\mathrm{T}_{\mathrm{g}}$ decreases with increasing of water content or water activity (Roos, 2007). Introducing flavour compound to such a complex structure as starch, it may get involved in structural evolution since the guest molecules are capable of interacting with intrinsic and atmospheric water.

\section{Nutritional aspect}

As above mentioned starch-based foods are important for human diet and serve as main energy source. Starch digestion can be classified into 3 categories: rapidly digestible starch (Edwards, Osborne, \& Henry), slowly digestible starch (SDS) and resistant starch (RS) according to their rates of glucose release and absorption in the gastrointestinal tract (Englyst \& Hudson, 1996; Hung, Vien, \& Lan Phi, 2016). SDS and RS are gaining interest due to their health benefits. SDS relates to low glycaemic index (GI) response which improves blood glucose control in diabetes mellitus patients (Chung, Lim, \& Lim, 2006). The GI stands for total glycaemic response in 2 hours immediately after consumption of $50 \mathrm{~g}$ carbohydrate and is expressed as a value relative to white bread or glucose (Chung, et al., 2006). RS is the non-digestible fraction by the small intestine but it can be digested by fermentation of colonic bacteria. The result products of RS fermentation are believed to have several health benefits such as prevention of colorectal cancer, lowering the risk of heart disease etc (Goñi, García-Diz, Mañas, \& Saura-Calixto, 1996; Hung, et al., 2016).

There are several research evidences suggesting that resistant starch as well as slowly digestible starch are formed not only through starch modification but also via hydrothermal treatments (Chung, et al., 2006; Holm, Lundquist, Björck, Eliasson, \& Asp, 1988; Hung, et al., 2016; Kawai, Takato, Sasaki, \& Kajiwara, 2012; Rodríguez \& Bernik, 2014). RS can be formed 
upon combination of acid and heat-moisture treatment without change in crystallinity (Hung, et al., 2016). Regarding resultant starches from hydrothermal treatment, their digestibilities can be altered depending on degree of crystallinity and type of interactions. The most important parameters affecting the kinetics of starch hydrolysis are crystallinity and surface area (Rahmouni, et al., 2001). The residual crystallinity in starch samples serves as structural rigidity and has inverse relationship with hydrolysis rate (Chung, et al., 2006). Amorphous matrices can be digested by the enzyme more easily and faster than the crystalline parts (Holm, et al., 1988; Rahmouni, et al., 2001). However, digestion rate of amorphous matrices can be different depending on degree of gelatinisation (Holm, et al., 1988). Partially gelatinised starch is found to be more resistant to enzyme digestion than the retrograded ones (Chung, et al., 2006). Considering structural organisation, it was found that B-type starch is more resistant to enzyme digestion than A-type starch (Tester, Qi, \& Karkalas, 2006). Complex formation which usually occurs between starch and its endogenous lipid or introduced ligands strongly decrease of starch enzymatic hydrolysis (Kawai, et al., 2012; Rodríguez \& Bernik, 2014). 
Chapter 2: Literature review 


\subsection{Starch structural and interaction studies}

\subsubsection{Chemistry and structure}

Starch, is a polysaccharide synthesised by green plant and stored as granule inside the plastids of tuber plants and endosperm of cereal plants. Starch granules are mainly found in seeds, roots, tubers, stems, leaves, fruits and even pollen (Pérez \& Bertoft, 2010). Leaf starch is synthesised in order to maintain homeostatic and metabolism of plant between low light time whereas tissue storage starch is synthesised during maturation of plant and utilised during germination of plant (Preiss, 2009). Biosynthesis of starch requires glucose as a precursor, then undergoes a complicate pathway with several enzyme interactions prior to become starch and storage as granules (Buléon, et al., 1998; Tester, Karkalas, \& Qi, 2004). The starch granules size (from 0.1 to $200 \mu \mathrm{m}$ ) and shape vary with the botanical origin (Pérez \& Bertoft, 2010). Two types of glucan (amylose and amylopectin) representing approximately $98-99 \%$ of dry weight are found in starch granules (Tester, et al., 2004). Amylose and amylopectin content in the starch granules vary depending on botanical source, development stage and growing conditions of the plant (Jenkins \& Donald, 1996; Tester, et al., 2004). The 'waxy' starches contain less than $15 \%$ of amylose, 'normal' one 20 $35 \%$ and high amylose starches more than $40 \%$ (Tester, et al., 2004). Purified starches contain $<0.6 \%$ of protein while cereal starch may contain integral lipid (lysophospholipids) and free fatty acid about $2 \%$ of starch weight. The percentages of protein and lipid contents included surface proteins/lipids (Tester, et al., 2004). Starch also contains $<0.4 \%$ of minerals (calcium, magnesium, phosphorus, potassium, and sodium) (Tester, et al., 2004).

Considering the two types of glucan "amylose and amylopectin", they are polymers of $\alpha$-D-glucose with different polymerisation degree, branching degree, structure and properties (Buléon, et al., 1998; Pérez \& Bertoft, 2010; Sablani, 2009; Waigh et al., 1997) (Figure 2-1). Amylose is a molecule mainly linear chain of $\alpha$-(1-4)-linked D-glucose, however the large molecular weight may contain up to ten or more branches at $\alpha-(1 \rightarrow 6)$ linkage (Buléon, et al., 1998; Imberty, Buléon, Tran, \& Péerez, 1991; Pérez \& Bertoft, 2010). Amylopectin is a branched molecule, with $\alpha$-(1 $\rightarrow 4)$-linked D-glucose backbone and exhibits about $5 \%$ of $\alpha-(1 \rightarrow 6)$ linked branches (Pérez \& Bertoft, 2010). The chains of amylose or amylopectin are arranged in double helices. The double helices are left handed and parallel stranded however there are two different types (A- and B- type crystalline polymorph) due to number of water molecules inside the crystal and their structural conformation (Buléon, 
et al., 1998; Imberty, et al., 1991) (Figure 2-2). In A-type crystalline polymorph, chains are crystallised in a monoclinic lattice and in type B type crystalline polymorph, chains are crystallised in a hexagonal lattice (Pérez \& Bertoft, 2010). The shortest amylopectin chains ( $<20$ glucose residues) are found in type A crystal whereas type B is made of the longest amylopectin chain length (Biliaderis, 2009). In addition to the structural difference between A- and B-type crystalline polymorph, A- is a thermodynamically stable form while B- is a kinetically favoured form (Kohyama, Matsuki, Yasui, \& Sasaki, 2004; Roos, 1995) as a result of the difference of amylopectin chains length (Biliaderis, 2009).
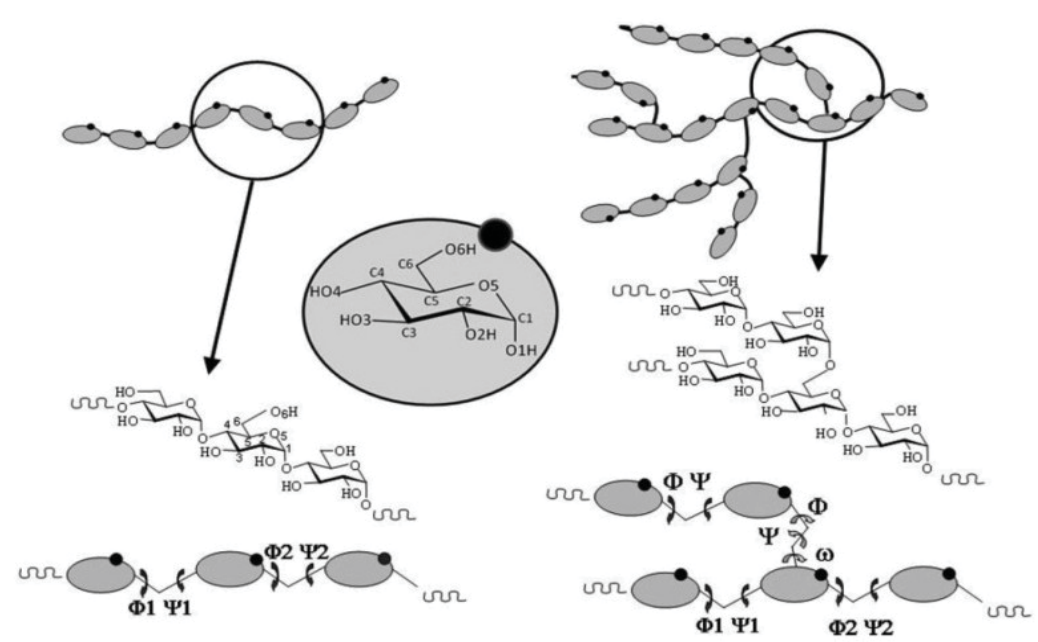

Figure 2-1: Basic structural motifs of amylose and amylopectin, along with the labelling of the atoms and torsion angles. Extension of the basic motifs to macromolecular structures (Pérez \& Bertoft, 2010).

The A-type crystalline polymorph is composed of 12 glucosyl units and 4 water molecules in the unit cell. Each glucosyl unit lines up on each strand and each strand is parallel. The strands are only stabilised by 0-2...0-6 hydrogen bonds. When the double strand is formed, there is no space for other molecules to occupy (Pérez, Baldwin, \& Gallant, 2009). The crystalline unit cell of A-type is monoclinic space group $B_{2}$. All the helices are lined up in parallel in the space group. The hydrogen bonds stabilise between each helix both directly or through the four water molecules present in the unit cell. The water molecules cannot be removed without complete disruption of the molecule since they are in the inner heart of the crystal (Buléon, et al., 1998; Pérez, et al., 2009; Popov et al., 2009). The B-type crystal is oriented in double helices mode but different from A-type crystal. The 
double helices are packed in hexagonal left-handed turn. B-type engulfs 36 molecules of water within the space group $\mathrm{P} 6_{1}$ crystal. The comparison between the different of A-and Btype structure are shown in Figure 2-2.

The difference between the two allomorphs is not only the quantity of water molecules stabilising the double helices but also the packing of double helices in the crystal unit cell ) (Imberty, et al., 1991; Pérez, et al., 2009; Tang, Mitsunaga, \& Kawamura, 2006). An additional explanation regarding crystalline arrangement represented in cross section view of the blocklet is shown in Figure 2-3. Applying heat-moisture treatment (low humidity, high temperature) to B-type crystalline polymorph leads to irreversible conformational change to A-type orientation (Buléon, et al., 1998; Imberty, et al., 1991).

(a)

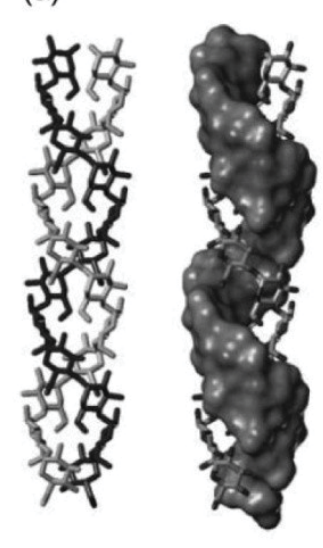

(b)

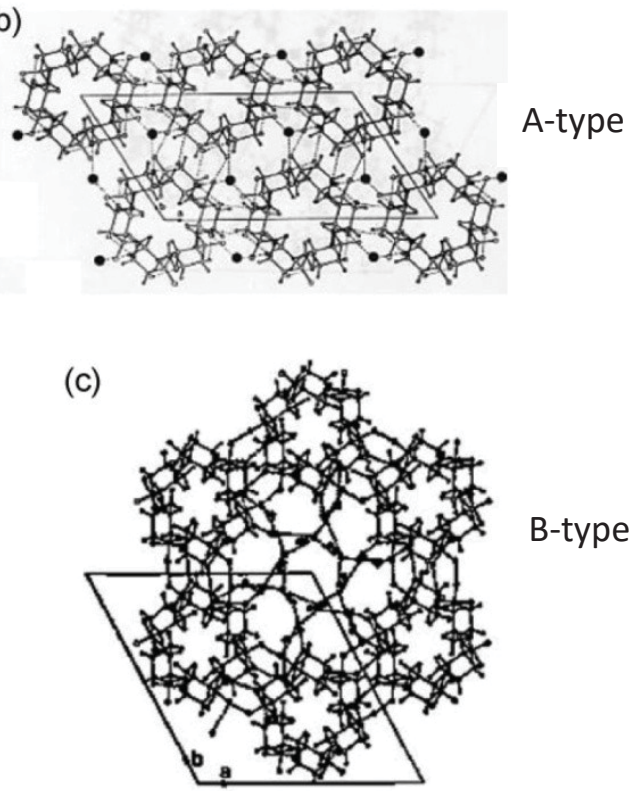

Figure 2-2: Crystalline packing of double helices in A-type (A) and B-type (B). Projection of the structure onto the $(a, b)$ plane (Pérez \& Bertoft, 2010).

Wheat starch is made of proportion between A- and B-type crystals as illustrated in Figure 2-4 (H-K. Huang, et al., 2014; Kim \& Huber, 2008). WAXS profiles in Figure 2-4 represent coexistence of monoclinic and hexagonal crystal (H-K. Huang, et al., 2014). The upper and lower rows of short rods at the bottoms are the possible WAXS reflections of Atype and B-type crystals, respectively. The dotted curve is the fitting residuals. The arrows mark the $(100)_{H}$ reflection of hexagonal crystal and the characteristic convoluted peaks at $q$ $=1.21$ and $1.28 \AA^{-1}$. 


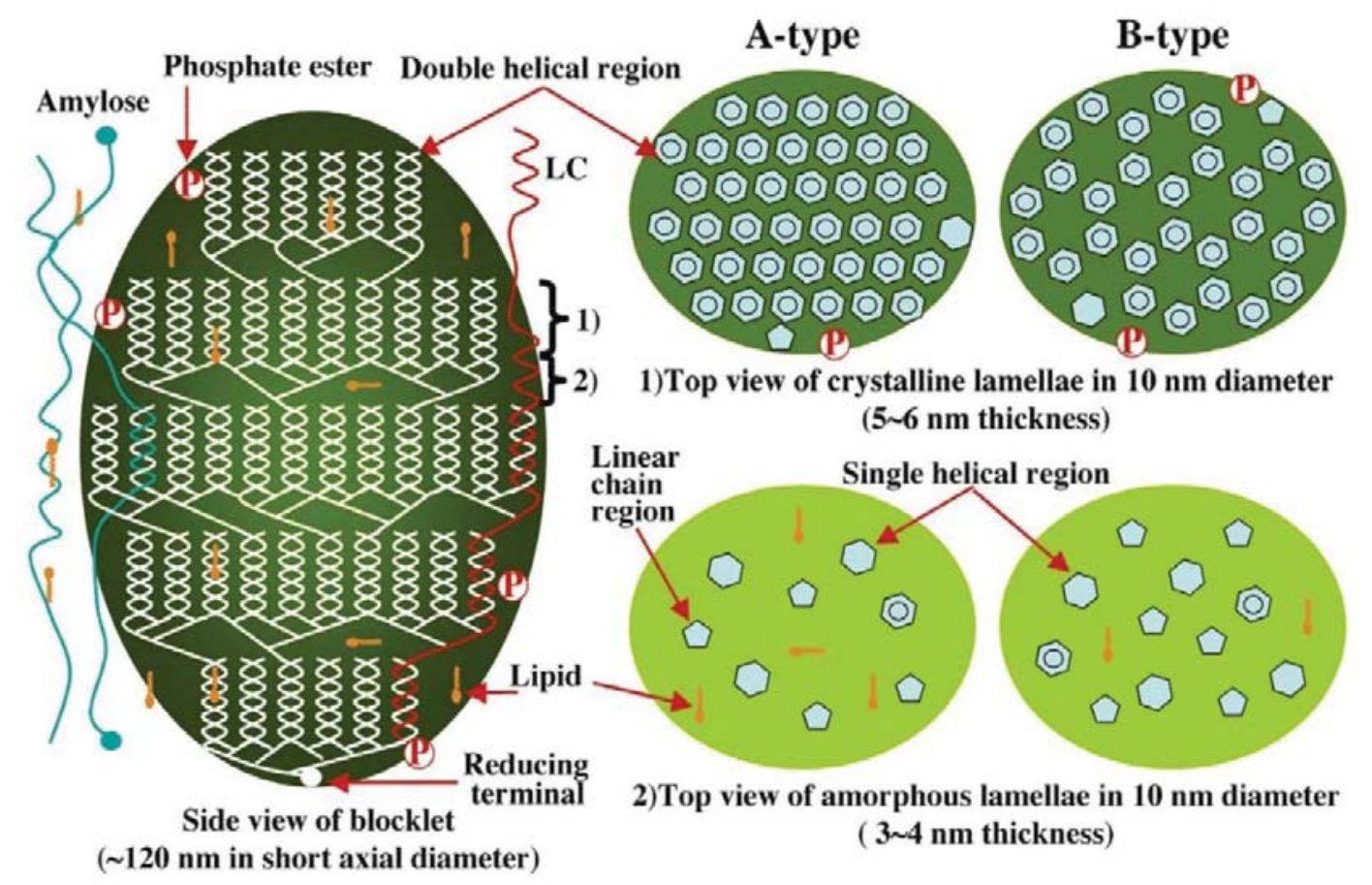

Figure 2-3: Schematic of normal blocklet structure in starch granule (Tang, et al., 2006)

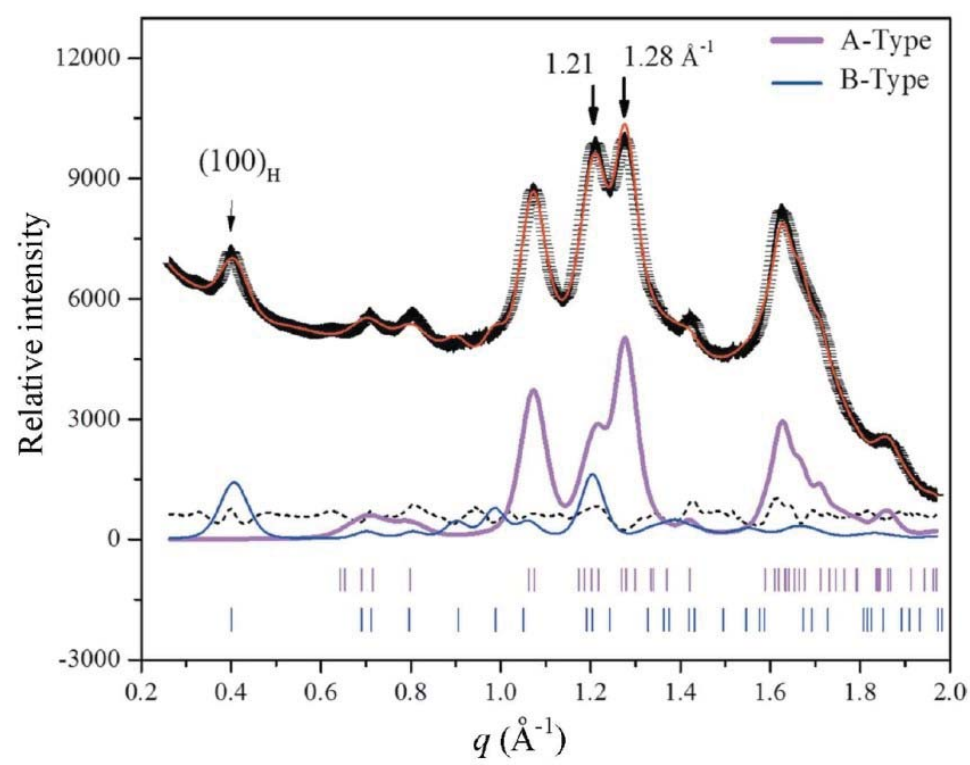

Figure 2-4: WAXS profile calculation based on coexistence of monoclinic and hexagonal crystals in weight ratio of 4:1. A-type crystal (purple line), B-type crystal (blue line) and curve-fitting residual (dotted line) (H-K. Huang et al., 2014)

Regarding X-ray diffractometry, native starch granules show three patterns of crystalline structure: A-, B-, C-type (Tang, et al., 2006). The C-type starch was found to be a unique structure gathering parts of A- and B-types. The outer part of C-type starch granule 
was found to contain A allomorph while B-type occupies the centre (Pérez, et al., 2009). It should be noted that another crystal feature can be found and it is classified as V-type starch. The difference in crystal feature between A-, B-, C-, V- type starch at granular level can be seen clearly by X-ray diffraction (Figure 2-5) (Imberty, et al., 1991; Roos, 1995). Atype starch is mostly found in cereal (rice, wheat, corn) (Pérez, et al., 2009; Roos, 1995). Btype starch is mostly found in some tuber plants, fruit and high amylose corn (Pérez, et al., 2009; Roos, 1995). C-type starch is found in legume seed starches (pea and bean) (Roos, 1995).

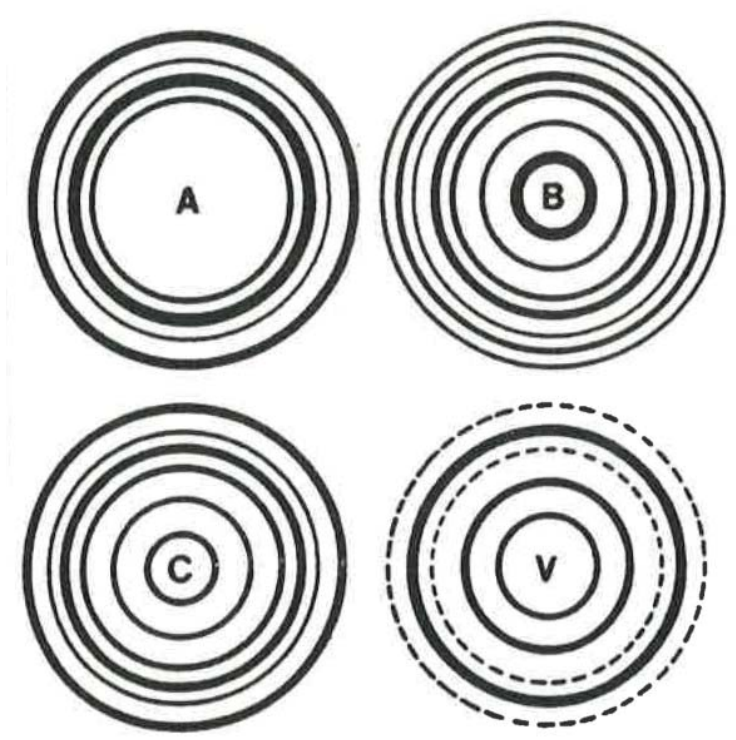

Figure 2-5: Schematic representation of X-ray diffraction patterns of various starches used for their classification into A-, B-, C-, and V-type starches (Roos, 1995; Zobel, Young, \& Rocca, 1988).

The V-type starch is not a natural form of crystal. It has rarely been detected in native starches and most native cereal starches containing fatty acid and/or monoglycerides (Biliaderis, 1991; Buléon, et al., 1998). The V-type crystal is not a natural form but it is inducible and can be observed in heated starch as a result of disruption of amylose helices followed by the formation of inclusion complex (Pérez \& Bertoft, 2010; Zobel, et al., 1988). Starch-lipid complex is an amorphous state in native starch granule, however it can be annealed into a more ordered semi-crystalline form (Pérez \& Bertoft, 2010). 
Crystallinity of starch granule associates with amylose and amylopectin content. Waxy corn starch contains nearly no amylose, however it possesses a crystallinity comparable to normal starches with amylose contents of $\sim 30 \%$ (Jenkins \& Donald, 1996)). Native wheat starch has approximately $36-39 \%$ of crystalline amylopectin, $23-32 \%$ for potato, and $25-48 \%$ for maize (Tester, et al., 2004). The variation of crystallinity is due to plant cultivation, tuber plant is grown under cool and wet conditions while the cereal is grown under warmer and drier (Biliaderis, 2009; Roos, 1995). Kohyama et al. (2004) made an assumption from several researches that different gelatinisation temperature can be found among the same species and cultivars due to environmental effects during plant maturation. The higher growing temperature, the higher the gelatinisation temperature (Kohyama, et al., 2004). Comparing two cultivars of winter wheat, the researchers evidenced that the size of granule is smaller and the number of amyloplasts per endosperm was lower. Amylose and lipid free amylose contents were found to increase with increasing growing temperature. Moreover, gelatinisation enthalpy and temperature were found to be different between cultivation conditions (Tester et al., 1995). The results of Tester et al. (1995) agree with Asaoka et al. (1985) that gelatinisation temperature increases with rising of growing temperature (Asaoka, Okuno, \& Fuwa, 1985; Tester, et al., 1995).

The study of starch granule under polarised light microscope, shows a typical birefringence in the form of Maltese crosses. This phenomenon is a consequence of high order of molecular orientation inside the starch granule. Examining starch granule under optical or electron microscopy, concentric rings were found. The rings composed of semicrystalline growth ring and amorphous growth ring (Jenkins \& Donald, 1996). The progress in spectroscopy and electron microscopy revealed that the semi-crystalline rings are composed of stacks of crystalline and amorphous lamellae (Jenkins \& Donald, 1996; Sablani, 2009). Each cluster contains a region which is high in branching points and less dense (the amorphous lamella) and a region where short chain segments of amylopectin have formed double helices (the crystalline lamella) (Jenkins \& Donald, 1996). The classical model of starch granule suggests that clusters of amylopectin arrange in radical orientation (Figure 26). However, the results of granule study by X-ray microfocus diffraction suggests that the peripheral amylopectin helices are not pointed into single focus orientation (Waigh, et al., 1997). The most recent evidences from combination of several microscopy and spectroscopy studies especially, SEM (Scanning Electron Microscope) and AFM (Atomic 
Force Microscopy) bring back the blocklet concept to be more acceptable (Gallant, Bouchet, \& Baldwin, 1997; H-K. Huang, et al., 2014; Oostergetel \& van Bruggen, 1993; Tang, et al., 2006). It actually requires both fibrillar (Figure 2-6) and blocklet concepts (Figure 2-7) to explain starch granule architecture. The fibrillar concept is applicable for radial organisation of starch while the blocklet concept relates to a higher order of crystalline organisation within the granules (Pérez, et al., 2009).

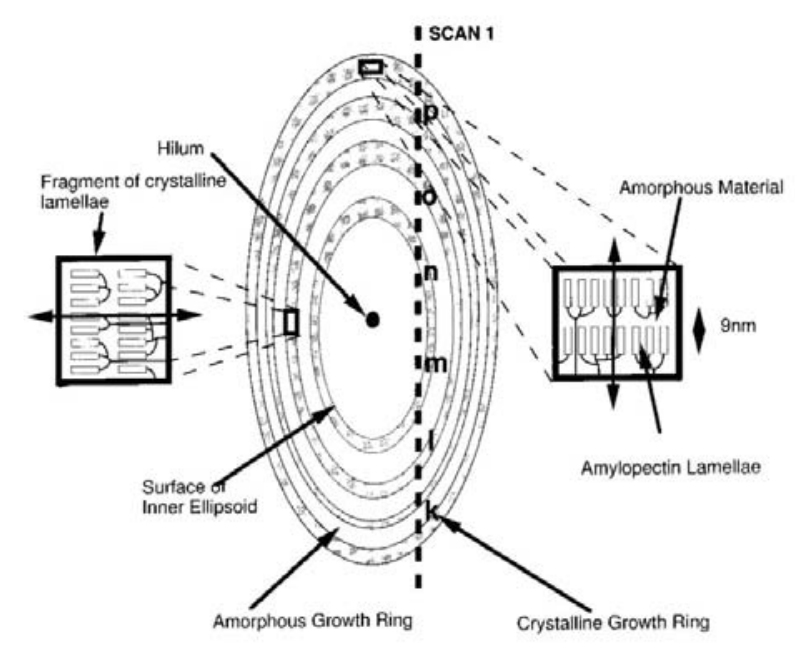

Figure 2-6: Starch granule in cross section showing the orientation of amylopectin double helices in the crystalline lamellae (Waigh, et al., 1997).

The overview of starch granule is shown in Figure 2-7, at the lowest level of granule organisation (upper left), the alternating crystalline (hard) and semi-crystalline (soft) shells are shown (black and white colours, respectively). The granule shells are thinner towards the granule exterior (due to increasing surface area to be added to by constant growth rate) and the hilum is shown off centre. At a higher level of structure the blocklet structure is shown, in association with amorphous radial channels. Blocklet size is smaller in the semicrystalline shells than in the crystalline shells. At the next highest level of structure one blocklet is shown containing several amorphous crystalline lamellae. In the next diagram the starch amylopectin polymer in the lamellae is shown. The next image reminds us that amylose-lipid (and protein) feature in the organisation of the amylopectin chains. At the highest level of order, the crystal structures of the starch polymers are shown (Gallant, et al., 1997). 


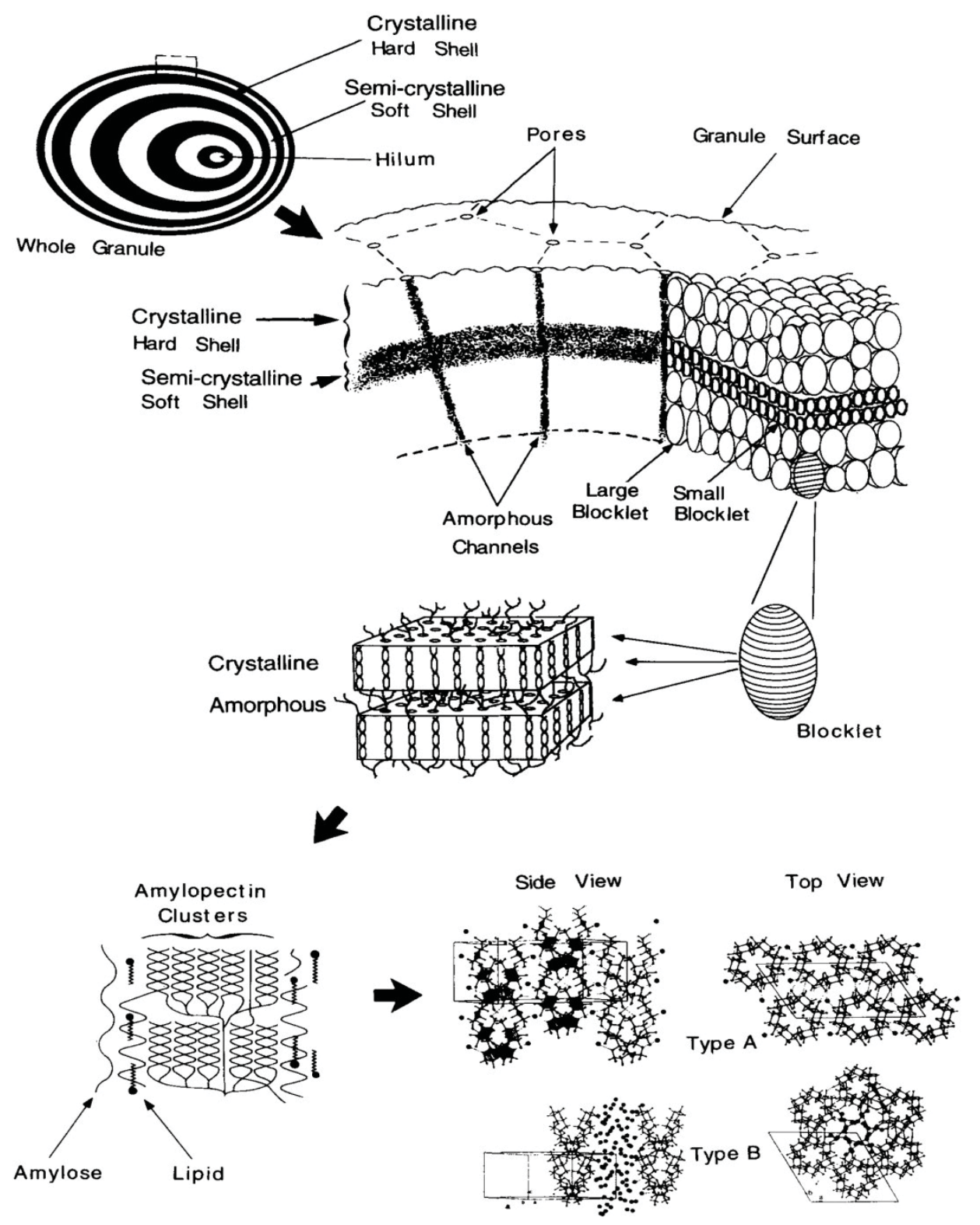

Figure 2-7: Overview of starch granule (Gallant, et al., 1997)

Size, form, surface, and size distribution of starch granules are important for both industrial and consumer since the granule properties control its applications. Wheat starch for instance, contains two main distinctive populations (Kim \& Huber, 2010a). The granule size distributions are usually monomodal or bimodal (Lindeboom, Chang, \& Tyler, 2004). Wheat granules possess bimodal distribution due to 2 populations of granule size. They are called granules type A and B (10-38 $\mu \mathrm{m}$ and $<10 \mu \mathrm{m}$, respectively) (Kim \& Huber, 2008). Generally, A-type granules account for more than $70 \%$ of the total starch weight but less than $10 \%$ of granules by number. B-type granules account for over $90 \%$ of the granules by number but less than $30 \%$ of the total starch by weight (Lindeboom, et al., 2004). The 2 
types of granules derived from wheat endosperm differ in amylose content, lipid-complex, amylopectin chain length, swelling capacity, relative granule crystallinity, gelatinisation properties, pasting behaviour, reactivity to amylase and reactivity to modifying agents (Kim \& Huber, 2008, 2010a, 2010b; Warren, Royall, Gaisford, Butterworth, \& Ellis, 2011). The small granules sizes with similar amylose content tend to have a lower pasting temperature and more amylose leakage (Kim \& Huber, 2010b; Lindeboom, et al., 2004). Granule swelling associates with granule structure and chemical composition, particularly amylose and lipid content, more than granule original size (Lindeboom, et al., 2004). The higher amount of amylose-lipid complex would inhibit swelling and gelatinisation (Kim \& Huber, 2010b; Lindeboom, et al., 2004). However, B-granules have a higher water absorption rate, thus earlier hydration and more swelling due to higher proportion of amorphous zones (more accessible to water) while A-granules contain higher crystallised arrangement (Kim \& Huber, 2010b; Lindeboom, et al., 2004). As the granule structures are different among starch types, the lengths of amylopectin double helices are also different. Potato starch exhibiting the longest ones (Tester \& Debon, 2000; Waigh, et al., 1997). The length of amylopectin helices is said to be possibly involved with the stability of starch through an increasing stability with increasing length (Waigh, et al., 1997).

\subsubsection{Starch and hydrothermal treatment}

Hydrothermal process plays a major role in starch function and structural rearrangement (Ratnayake, et al., 2008). Without heating, starch granules are poorly soluble, uptake only certain amount of water and swell to a limited extent even though an excessive amount of water has been added into the system (Biliaderis, 2009; Ratnayake, et al., 2008). In cold starch suspension, native starch granules only suspend as colloid and settle as sediment in absence of shear or motion applied to the suspension, the granules can retain their original birefringence and size via dehydration. The structure and property of starch are altered upon hydrothermal treatment (Jenkins \& Donald, 1998; Ratnayake, et al., 2008; Tester \& Debon, 2000). It is crucial to distinguish the types of hydrothermal induced that could be applied to starch because starch is sensitive to temperature, water-ratio and time which finally result in different properties of the studied starch (Tester \& Debon, 2000; Tester, Debon, \& Karkalas, 1998; Zavareze \& Dias, 2011). The difference in term of water contents and temperature treatments applicable to starch are simplified in Figure 2-8 
(Biliaderis, 2009). Application of low water content up to $40 \%$ and heating above $55{ }^{\circ} \mathrm{C}$ is defined as heat-moisture treatment. Annealing and gelatinisation are the applications of water contents range between $30-100 \%$ but they are different in heating temperature. Annealing usually occurs at low temperature up to $50{ }^{\circ} \mathrm{C}$ whereas gelatinisation usually occurs above $50^{\circ} \mathrm{C}$.

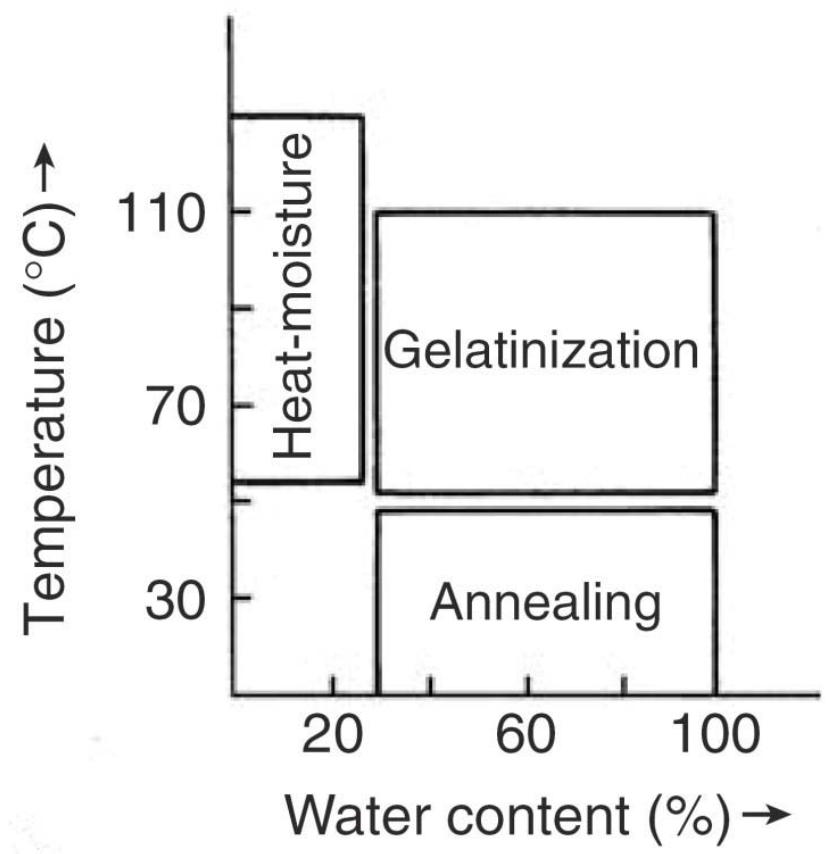

Figure 2-8: Heat-moisture treatment of starch versus water content and temperature in starch (Biliaderis, 2009)

\subsubsection{Gelatinisation and phase transition upon hydrothermal treatment}

Gelatinisation is a consequence of several occurrences, an initial step account from starch granule uptaking water, and it begins in the most water-accessible amorphous regions of the granule where intermolecular bonding is weak. The process followed by granule swelling, crystallite liquefying, birefringence disruption, starch solubilisation and viscosity development. The study of wheat starch swelling revealed that the granules begin to swell at $45-50{ }^{\circ} \mathrm{C}$, followed by a loss of birefringence (Ratnayake, et al., 2008; Tester \& Morrison, 1990).

The study of wheat starch swelling revealed that the granules begin to swell at 45-50 ${ }^{\circ} \mathrm{C}$, followed by a loss of birefringence (Tester \& Morrison, 1990). Gelatinisation 
enthalpy attributed to dissociation of crystalline cluster dramatically decreases at $50-55{ }^{\circ} \mathrm{C}$ and the enthalpy of double helices dissociation is lost at $55-60{ }^{\circ} \mathrm{C}$ (Tester \& Morrison, 1990). Partially or fully swollen starch granule is a crucial parameter for pasting behaviour and rheological properties of some food systems. Swelling factor is strongly correlated with the leaching of polysaccharide (amylose and / or amylopectin, depending on the starch) which finally correlates with the starch ability to gel (Tester \& Morrison, 1990). Along with the gelatinisation process, the changes can be visualised. Once, the solution is heated, the texture becomes slurry and opaque. As soon as the granule reaches its gelatinisation temperature, the granule can no longer absorb water and starch becomes a paste upon cooling due to amylose leaching, which then forms a gel network (BeMiller \& Whistler, 1996; Biliaderis, 2009; Ratnayake, et al., 2008; Roudaut, Simatos, Champion, ContrerasLopez, \& Le Meste, 2004). Gelatinisation process and structural transformation is illustrated as shown in Figure 2-9.

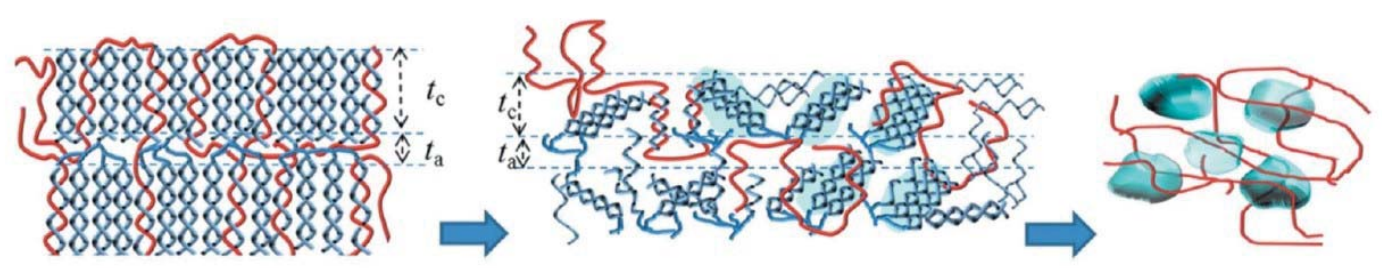

Figure 2-9: Melting process of the semi-crystalline lamellae. Schematically shown (left) are stacked lamellae of well packed crystalline nanoclusters of amylopectin (blue) and amylose (red) chains. Melting of defect-rich regions leads to partial loss of integrity of the lamellae, into layers alternating rich and poor in tilted disordered nanoclusters (shaded background in blue), as shown in the middle. The process ends with disperse and molten nanoclusters (bright blue) of amylopectin loosely associated with relatively untangled linear amylose chains (right) (H-K. Huang, et al., 2014).

Starch gelatinisation is a complex process and it is complicated to explain the changes occur during gelatinisation. It has been decades that numerous researchers tried to explain gelatinisation process and structural changes upon gelatinisation (Biliaderis, 2009; Ratnayake, et al., 2008). Ratnayake and Jackson (2008) collected all the possible theories of gelatinisation and evolution of gelatinisation studies. In 1940s, gelatinisation was described 
as 3-steps change process. The first phase is a slow absorption of water by starch granule, which is a reversible process. The second phase is granule swelling which begins within a narrow temperature range. The volume increase during swelling leads to a loss of birefringence. Starch becomes more solubilised and rise in viscosity. At this stage, the changes of granule properties are no longer reversible. The third phase of swelling is a part of further temperature increase. The granules become formless sacs, leaches out more soluble portion of starch into the suspension and finally result in granule disruption. A starch gel is able to form during the mixture cooling.

The 2-phases swelling observed in some cereal starches emphasises the two distinct groups of internal bonding forces inside the granules, that is, amorphous and crystalline regions (Ratnayake, et al., 2008). Marchant and Blanshard (1978) suggested a semi-cooperative theory in which gelatinisation composes of (1) water diffusion into the starch granule, (2) loss of birefringence due to "hydration facilitated melting" and (3) granular swelling predominantly after loss of birefringence (Ratnayake, et al., 2008). In addition to "semi-cooperative" theory, the initial phase of gelatinisation describes a situation where a significant portion of granule crystallites are melted and the resultant changes induce the remaining crystallites, along with the entire granular structure, to disintegrate in a second phase.

Along with the study of starch gelatinisation by DSC at both low and high moisture level, Donovan proposed the "water availability theory" which insisted that water is a key factor of phase transition process in starch granule (Donovan, 1979). Variation of water content in studied conditions has shown the influence of water on gelatinisation and associated DSC endotherms. Biphasic DSC endotherms were observed with potato starch by Donovan (water: starch volume fractions $<0.45,150^{\circ} \mathrm{C}$ ) whereas three DSC endotherms were observed in wheat starch $\left(35-80 \%\right.$ w/w water, $\left.140{ }^{\circ} \mathrm{C}\right)($ Chung $\&$ Lim, 2004; Eliasson, 1980; Ratnayake, et al., 2008). Multiphasic DSC endotherms were found when moisture levels were decreased below 35\% (Eliasson, 1980; Jang \& Pyun, 1996). The study of Eliasson (1980) agreed with Donovan (1979) that the second DSC endotherm disappeared when starches were mixed with excess water. The variation of DSC endotherms with water content were gathered and compared in Figure 2-10 (Roos, 1995). According to the figure, heating with high water contents over the gelatinisation temperature range produces a single endotherm, M1. At intermediate water contents another endotherm, M2 is observed 
as a shoulder of the M1 endotherm or as a separate endotherm. At low water contents only $\mathrm{M} 2$ is obtained. The melting temperature, $\mathrm{T}_{\mathrm{m}}$, increases with increasing water content (Roos, 1995). Eliasson (1980) did not classify the third endotherm, but the evidences from latter studies postulated that this third endotherm is actually a complex between amylose and granular lipid (Biliaderis, 1992; Biliaderis, Page, Maurice, \& Juliano, 1986; Jang \& Pyun, 1996). The crystalline regions are the same throughout the starch granule and the phase transition mechanism depends only on water availability. The case of single endotherm observed in excess water is due to water imbibitions by amorphous regions which lead to stripping of starch chains from crystallite surfaces. Donovan suggested that in excess water conditions, the water is distributed throughout starch granule as well as crystallite surface. The water acts as plasticiser and strips the crystallite from surface (Donovan, 1979; Ratnayake, et al., 2008). As a result of starch chains stripping, then there is no crystallite remain to be melted at high temperature. Considering the biphasic endotherms, they are up to different mechanisms by which ordered regions of starch granule undergo hydration facilitated phase transition. It is possible that some crystallites melt at low temperature as a result of water-facilitated plasticisation while some other crystallites melt at high temperature without the plasticising effect of water. In addition to the two distinct melting behaviours, at low temperature melting (water-facilitated melting) allows optimum hydrogen bonding transfer from starch polymer cluster to water whereas the nonplasticising melting is possible due to realignment of crystallites by hydrogen bond transfer among starch polymers (Donovan, 1979; Ratnayake, et al., 2008).

Crystallite stability theory is proposed to explain biphasic endotherm observed in low moisture system and to argue explanation of crystallite melting proposed by Donovan (Ratnayake, et al., 2008; Tester \& Morrison, 1990). In addition to biphasic endotherm, the least stable crystallites first melt which then eliminates some of the constraints restricting the granule from absorbing additional external water. Gelatinisation process under crystallite stability is the process of melting of less-perfect (least stable) crystallites (corresponding to the $T_{0}$ in DSC endotherms) which subsequent progressive melting into perfect (more-stable) crystallites regions. However, Ratnayake and Jackson (2008) debated with more recent researches that DSC endotherms represent crystallite melting during starch gelatinisation process is in valid since starch granules need energy to absorb water and swell unless water absorption into starch granules should occur without any energy 
utilisation (Biliaderis, 1991, 1992; Ratnayake \& Jackson, 2007; Ratnayake, et al., 2008; Vermeylen et al., 2006).

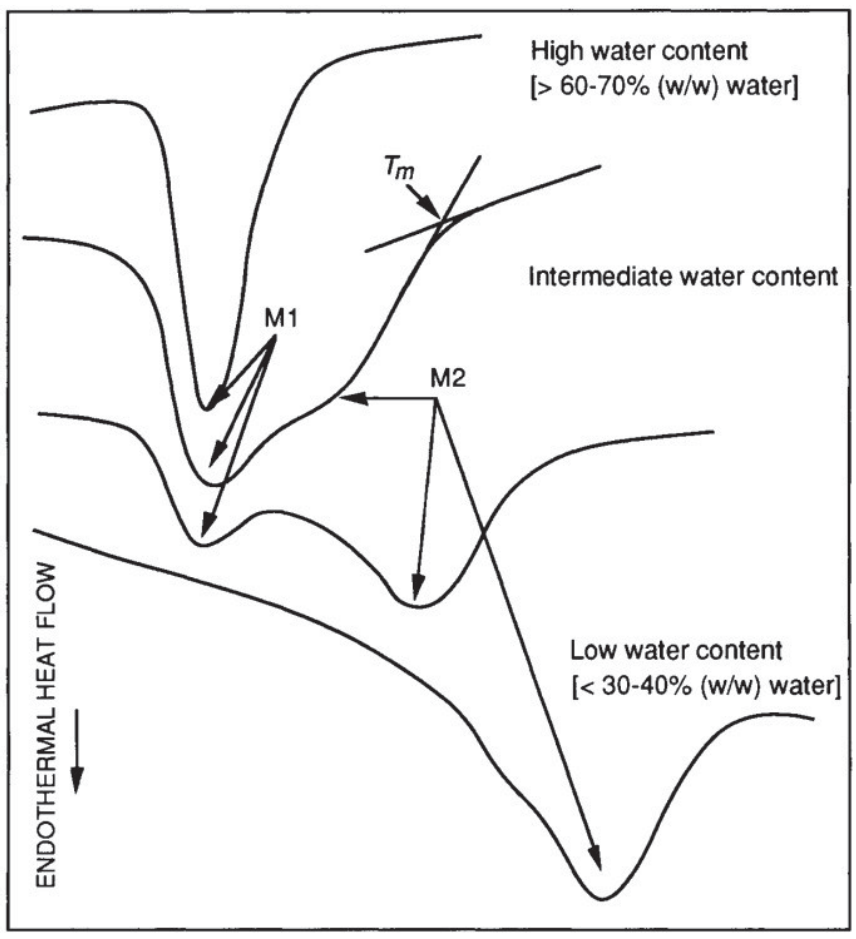

Figure 2-10: A schematic representation of DSC thermograms typical of starch when heated with various amounts of water (Roos, 1995).

Several approaches have been applied to explain gelatinisation process in various aspects depending on the techniques (Ratnayake, et al., 2008). This is because the two techniques are independent (Nakazawa, Noguchi, Takahashi, \& Takada, 1984). Starch gelatinisation and phase transition are complex processes and they would be different depending on type of starch, sample treatment and study conditions (Ratnayake \& Jackson, 2007; Ratnayake, Otani, \& Jackson, 2009). Biliaderis et al., (1986) concluded that thermal properties such as transition temperature, enthalpies, and volume expansion characteristics were significantly correlated with other physicochemical properties (amylose content, final birefringence end-point temperature, etc.). Therefore, it is necessary to apply the result from several analysis approaches together to explain the changes under each studied conditions (Biliaderis, 1992; Ratnayake \& Jackson, 2007).

When the granules undergo gelatinisation, phase transition also occurs. While starch gelatinisation is a structural reorganisation and collapse of the molecule, starch phase 
transition is the physical and thermodynamic transformation of semi-crystalline material under specific conditions (Biliaderis, 1991). Phase transition can be observed under DSC analysis (Biliaderis, et al., 1986; Jang \& Pyun, 1996; Ratnayake \& Jackson, 2007): the technique measures heat flow changes associated with both first-order (melting) and second-order (glass transition) transitions of polymeric materials (Biliaderis, et al., 1986). The involvement of phase transition upon gelatinisation brings about sequential phase transition (first amorphous and then crystalline) theory. The study of Nakazawa et al. (1984) worker in rice starch by DSC and XRD suggested that transitions were associated with granular restructuring.

At low temperature below $T_{0}$ (DSC onset temperature of gelanitisation), the amorphous phase became mobile but the crystalline region remains immobile. DSC gelatinisation temperatures (onset and peak temperature) increased upon increasing of annealing degree. It is suggested that the energy was used at low temperature for starch polymer rearrangement and for crystallite melting at high temperature $\left(75^{\circ} \mathrm{C}\right)$. Hence, they proposed that amorphous and crystalline phase transition occurred sequentially during DSC (Ratnayake, et al., 2008). According to this theory, longer time and higher temperature (above gelatinisation) treatment decreased the crystalline: amorphous ratio within starch granules, thus single DSC endotherm should be obtained. The obtained DSC result showed that the peak temperature increased and enthalpy changed without particular pattern with rising of sub-gelatinisation temperature. Ratanayke and Jackson (2008), indicated that crystallite stability theory better explains these observations. Although the study of Nakazawa et al. (1984) cannot completely explain the gelatinisation and structural change upon gelatinisation, it evidenced the importance of annealing (time and temperature) and ratio of amylose and amylopectin. Native starch (80\% amylopectin-containing, 20\% amylose required more energy than native $100 \%$ amylopectin-containing starch to become amorphous.

Regarding starch as semi-crystalline material and gelatinisation as a nonequilibrium (irreversible) process, three-stage (partial melting, recrystallisation, and total melting) phase transition theory was proposed by Biliaderis et al. (1986). Three-phase model consists of (1) fully ordered crystalline phase, (2) non-ordered intercrystalline phase, and (3) bulk amorphous phase. A schematic representation of starch granule considered in this model is represented in Figure 2-11. The researchers postulated that DSC transitions 
represented a composite result of melting and reorganisation occurring during thermal analysis instead of presented initial semi-crystalline structure phase transition of starch (Ratnayake, et al., 2008). Biliaderis et al. (1986) suggested that starch undergoes reorganisation similar to annealing phenomenon described in a further paragraph (Biliaderis, et al., 1986; Ratnayake, et al., 2008). Gelatinisation according to this theory is composed of three phases: partial melting, recrystallisation and final melting (Biliaderis, et al., 1986; Ratnayake, et al., 2008). It should be noted that both annealing and recrystallisation processes depend on moisture content and these processes become prominent at high moisture levels (Biliaderis, et al., 1986; Ratnayake, et al., 2008).

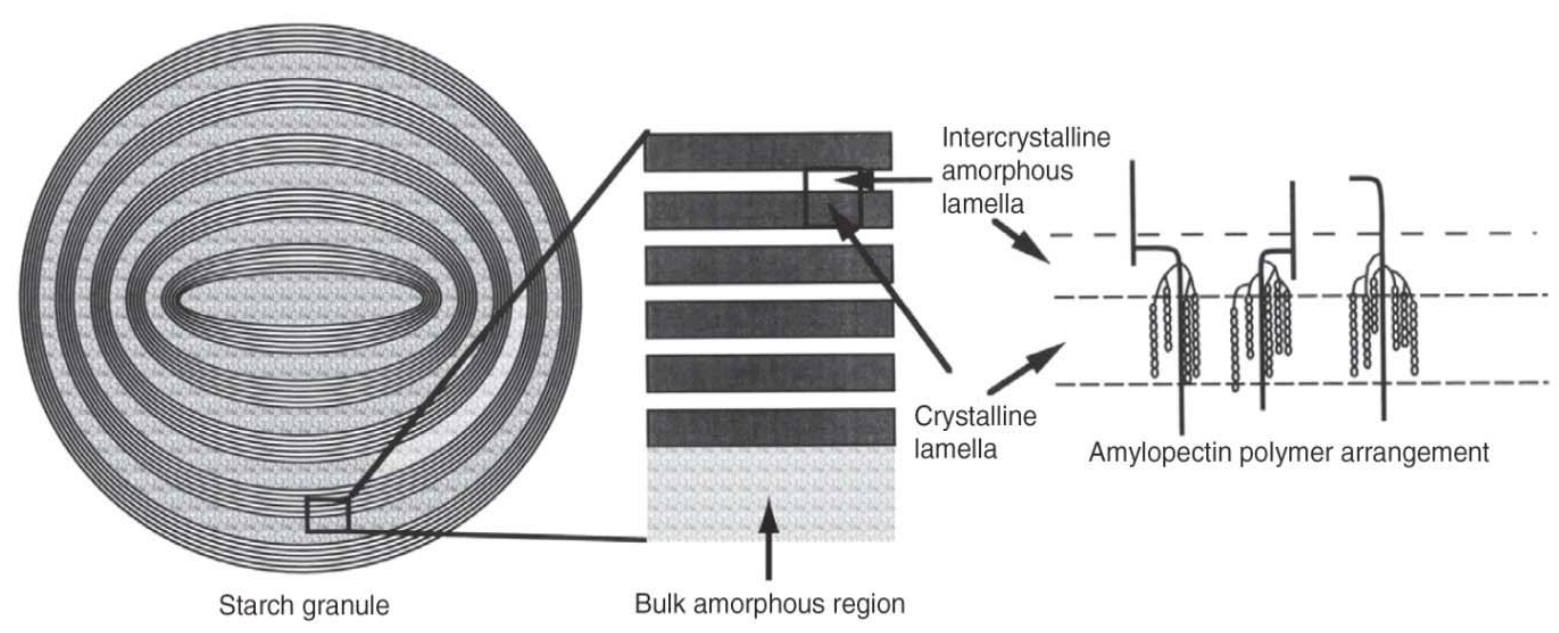

Figure 2-11: Schematic diagram of starch granule structure - representation 3 phase component: crystalline, intercrystalline amorphous and bulk amorphous components (Ratnayake, et al., 2008).

There are disagreements in the literature among the existing gelatinisation theories (Waigh, et al., 1997). The results of further studies facilitate more understanding in gelatinisation. In addition to theories on starch gelatinisation and phase transition, hydration studies of B type starch at ambient temperature revealed that water plasticises the amorphous lamellae and allows the amylopectin helices present in amorphous lamellae to organise side by side with more organisation compared than the dry equivalent (Waigh, et al., 1997). This result supports that such structural reorganisation occurs at temperature lower than onset temperature. The study by combination of SAXS/WAXS/DSC and SANS 
revealed that water enters first amorphous growth rings where all the swelling is then concentrated (Jenkins \& Donald, 1998).

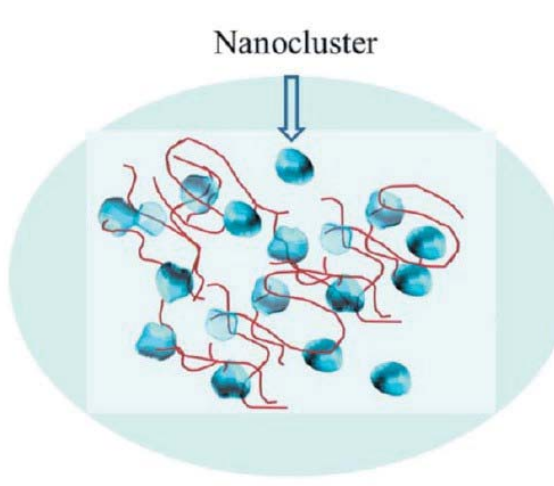

Gelatinization

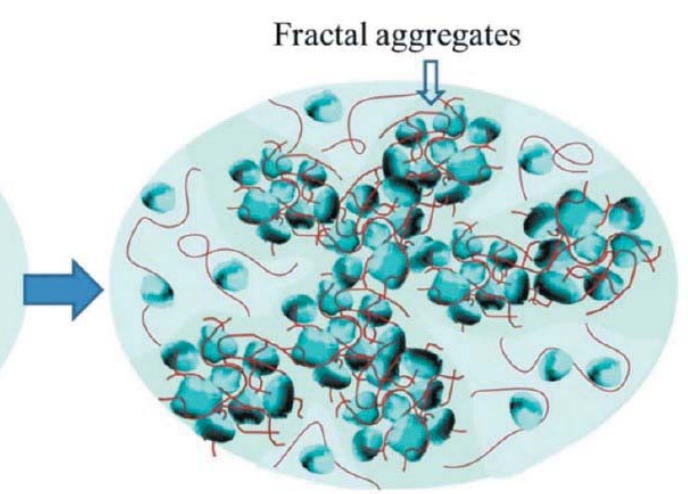

Gelation

Figure 2-12: Gelatinisation for disperse linear amylose chains and ellipsoidal nanoclusters of amylopectin, of dimension ca $7 \times 3 \times 3 \mathrm{~nm}$ (left); gelation for loosely fractal-structured networks on a micrometer scale (right) (H-K. Huang, et al., 2014).

The study of correlated changes in structure and viscosity during gelatinisation of tapioca starch (21\% amylose) by SAXS/WAXS and solution viscometry revealed concomitant occurrence of lamellar nanocrystals melting, disintegration of constituting blocklets, and the resulting dissipation of the semi-crystalline layers upon gelatinisation during heating in excess water to $60-74{ }^{\circ} \mathrm{C}$ (H-K. Huang, et al., 2014). Upon gelatinisation, nanocrystals melt and disintegration of blocklets into prolate nanoclusters of molten amylopectin release amylose chains into the aqueous phase. Following the treatment, amylose chains are trapped by cocrystallisation process with amylopectin in blocklets of 40 $50 \mathrm{~nm}$. The viscosity rapidly increases after complete dissipation then gelation occurs during cooling. Amylopectin nanoclusters are connected by amylose chains in fractal-structured networks of gradually increasing fractal dimension (H-K. Huang, et al., 2014). The resulting model of structural alteration after gelatinisation and gelation is shown in Figure 2-12.

\subsubsection{Heat-moisture}

Heat-moisture treatment is described as a physical modification altering the physicochemical properties of starch without destroying its granular structure (Zavareze \& Dias, 2011). Following, the application of thermal treatment at temperature greater than 
gelatinisation temperature but in moisture conditions limiting the starch gelatinisation (Zavareze \& Dias, 2011). More precisely, the term heat-moisture has been referred to high temperature treatments, $84-120^{\circ} \mathrm{C}$ for instance (for period of time between $15 \mathrm{~min}-16 \mathrm{~h}$, and for 10-35\% moisture content) (Gunaratne \& Hoover, 2002; Tester \& Debon, 2000; Zavareze \& Dias, 2011). It was found that heat-moisture treatment affects starch structure (X-ray pattern), crystallinity, starch chain interactions, granule swelling, amylose leaching, viscosity, gelatinisation parameters, retrogradation, acid and enzyme hydrolysis (Gunaratne \& Hoover, 2002). However, the results of heat-moisture treatment vary depending on the type of starch (Gunaratne \& Hoover, 2002; Zavareze \& Dias, 2011) e.g. tuber and root starches are found to be more susceptible to heat-moisture treatment than legume and cereal starches (Gunaratne \& Hoover, 2002).

Heat-moisture treatment $\left(15-35 \%\right.$ moisture content, $\left.120^{\circ} \mathrm{C}, 12 \mathrm{~h}\right)$ in mung bean starch has showed to increase resistant starch content, gelatinisation temperature, enthalpy of gelatinisation and solubility increase decrease swelling power and a loss of central birefringence (not at the periphery) occurring at 30\% moisture content (S. Li, Ward, \& Gao, 2011). The loss of birefringence at the center of granule associated with high temperature was suggested to offer thermal energy to the double helices and promote their mobility (S. Li, et al., 2011). Li et al. (2011) report that relative crystallinity of mung bean starch is increased after heat-moisture treatment possibly due to association with new crystallisation and perfection of the small existing crystalline regions of starch granule. The increase in resistant starch is the result of strong associations between molecular chains leading to a tighter structure within starch granule after the treatment. Moisture content plays an important role in resistant starch content since water creates hydrogen bonds between molecular chains (S. Li, et al., 2011).

The study of various type of tuber starches (potato, taro, new cocoyam, true yam, and root cassava demonstrated that heat-moisture treatment $\left(100{ }^{\circ} \mathrm{C}, 10 \mathrm{~h}\right.$ and $30 \%$ moisture content) of B-type starches was altered to A+B-type, causing a decrease in swelling factor, amylose leaching, gelatinisation enthalpy, and susceptibility towards acid hydrolysis and increase in gelatinisation temperature and enzyme susceptibility (Gunaratne \& Hoover, 2002). Concerning structural transformation from B-type to A+B-type, it was postulated to be due to dehydration/vaporisation of the 36 water molecules located in the B-type starch, and a movement of a pair of double helices into the central channel (which was initially 
occupied by the water) (Gunaratne \& Hoover, 2002). Decrease in amylose leaching is suggested to be due to interaction between amylose molecules and between amylose and amylopectin whereas decrease in swelling factor relates to decreased crystallinity and granular stability since these 2 are involved in the unwinding of double helices (Gunaratne \& Hoover, 2002; S. Li, et al., 2011). Heat-moisture treatment contributes to the unwinding of double helices which is directly reflected in the reduction of gelatinisation enthalpy (Gunaratne \& Hoover, 2002; S. Li, et al., 2011). The increasing melting temperature is indirectly controlled by the surrounding amorphous matrix. Since the granular swelling is reduced, the destabilisation effect of the amorphous region on crystallite melting is also reduced. Therefore, the higher temperature is required for melting crystallites of heatmoisture treated starches (Gunaratne \& Hoover, 2002). There are 3 possible factors to explain the change in the hydrolysis extent/sensitivity of hydrolysis after heat-moisture treatment: (1) crystallite disruption (increases acid hydrolysis by accessibility to creating more amorphous regions; (2) interactions between starch chains decreases hydrolysis; and (3) disruption of double helices in the amorphous regions (Gunaratne \& Hoover, 2002). In case of enzyme susceptibility, it is directly due to crystallite and amorphous disruption. The changes of B-type starch to A-type and A+B-type is reported to be depend on starch chain length as it is shorter in A-type starch. The change in starch configuration is also related to molecular orientation (unit chain and degree of polymerisation) (Gunaratne \& Hoover, 2002; Ji et al., 2015).

Collado \& Corke (1999), report that pasting profile of two sweet potato types (15.2 and $28.5 \%$ amylose) shift from type A to type $C$ after heat-moisture treatment. Type $A$ pasting profile is characterised by a high to moderate pasting peak, major breakdown after holding time at $95{ }^{\circ} \mathrm{C}$ and low cold paste viscosity while type Clacks of a pasting peak, and shows no breakdown (Collado \& Corke, 1999). The researchers explain that the strengthening in intragranular binding force makes the granules resist deformation (Collado \& Corke, 1999).

The study of heat-moisture treatment in the presence of other plasticisers rather than water (e.g. xylitol, propylene glycol, glycerol, and propanol) demonstrates that the plasticisers change pasting properties of starch by reducing the viscosity (Juansang et al., 2015; Q. Sun, Dai, Nan, \& Xiong, 2014). Opposite results from 2 researches are observed on pasting temperature. Pasting temperature of wheat starch is increased after heat-moisture 
treatment in the presence of xylitol (Q. Sun, et al., 2014) while it is contrast for canna starch (Juansang, et al., 2015).

No significant change in granule size and shape were detected in canna, corn and potato starches after heat-moisture treatment (Ji, et al., 2015; Jiranuntakul, et al., 2011; Juansang, et al., 2015) while the effect of heat-moisture treatment is more pronounced in wheat and rice starches (Jiranuntakul, et al., 2011; Q. Sun, et al., 2014). The change in granule surface depends on botanical source and conditions of study. Wheat starch after heat treatment is found to increase in granule surface roughness whereas the smooth surface is observed in normal rice, waxy rice and normal corn starches (Jiranuntakul et al., 2013). The changes on granule surface associate with crystalline structure, gelatinisation properties, and re-association of molecular structure (Jiranuntakul, et al., 2013; Q. Sun, et al., 2014).

The thermal properties of wheat starch are reported to be altered after heatmoisture treatment through an increased onset $\left(T_{0}\right)$, peak $\left(T_{p}\right)$ and conclusion temperature $\left(T_{c}\right)$ of gelatinisation (Q. Sun, et al., 2014), due to a stable configuration resulting from realignment of polymer chains with the non crystalline region of the granule $(Q$. Sun, et al., 2014). The increasing $T_{c}-T_{0}$ relates to the increasing heterogeneity of crystallites within the starch granules and results in broader gelatinisation range (Gunaratne \& Hoover, 2002; Q. Sun, et al., 2014). The gelatinisation enthalpy of wheat starch decreases after heat-moisture treatment due to lowering in degree of crystallinity (Q. Sun, et al., 2014). No change in X-ray diffraction is observed in wheat starch after heat-moisture treatment, however the diffraction pattern is deviated with heat-moisture treatment of starch-xylitol sample. It is suggested that the guest molecule interacts with starch that cannot recrystallise after cooling, which increases in amorphous region (Q. Sun, et al., 2014).

\subsubsection{Annealing}

Another important hydrothermal treatment to taken into account is annealing. Contrary to the previously described heat-moisture treatment, annealing refers to the application of thermal treatment above $T_{g}$ but below the gelatinisation temperature and intermediate or excess water content (40-55\% to >60\%) (Tester \& Debon, 2000; Zavareze \& Dias, 2011). That is to say, gelatinisation depends on thermal history of the starch (Biliaderis, 1992; Ratnayake, et al., 2008; Tester, et al., 1998). 
It is believed to:

- reorganise granular structure

- thus to increase granule stability

- increase the crystallites perfection

and consequently to

- elevate gelatinisation temperature

- narrowing gelatinisation temperature range (Tester \& Debon, 2000)

- decrease swelling factor and amylose leaching

- increase in hot and cold paste viscosities ((Jayakody \& Hoover, 2008; Tester, et al., 1998; Waduge, Hoover, Vasanthan, Gao, \& Li, 2006).

Crystalline perfection, it may evolve due to: (1) a crystal size increase (2) a change of crystal shape, (3) a change in direction of crystal growth, (4) orientation of crystallites, (5) interactions between crystallites and (6) changes within the amorphous regions (Jayakody \& Hoover, 2008). Several authors report no significant change on starch granule morphology after annealing (Jayakody \& Hoover, 2008). Tester et al. (1998) postulated an assumption that there should be no crystallinity loss attributed to the uncoiling of amylopectin double helices and rupture of their stabilising hydrogen bonds as they are directly associated with gelatinisation endotherm. Tester and co-workers (1998) concluded that there was a sequence of events occurring upon annealing and explaining its effects. The process involves hydration and expansion of amorphous regions which initiate re-organisation of the spatial location of double helices with respect to one another. Glass transition or mobility of amorphous regions greatly rely on the annealing temperature. The most effective annealing temperature is the vicinity of gelatinisation onset temperature (Jayakody \& Hoover, 2008; Tester, et al., 1998) while the most effective moisture to allow unrestricted molecular motion (or glass transition) within amorphous regions is more than $60 \% \mathrm{w} / \mathrm{w}$ (Tester, et al., 1998). Annealing is shown to lead to an increased order in amorphous regions through the reorganisation of double helices into cluster following the mobility increased by annealing. Annealing can be simply described as the physical reorganisation within starch granules (or appropriate polysaccharide matrices like amylose-lipid complexes) when heated in water (or appropriate plasticiser) at 
temperature between $T_{g}$ and onset of gelatinisation $\left(T_{0}\right)$ (Tester \& Debon, 2000; Tester, et al., 1998).

The study of normal, waxy, high amylose bread wheat starches show that the concentration of amylose, lipid-complexed amylose chains, gelatinisation temperature range, swelling factor, amylose leaching, peak viscosity, final viscosity, set back, light transmission, susceptibility toward $\alpha$-amylase, and acid hydrolysis and the proportion of small $(2-8 \mu \mathrm{m})$ B-type granules decreased upon annealing at $10{ }^{\circ} \mathrm{C}$ below gelatinisation onset temperature for $72 \mathrm{~h}$ (approximately 60\% moisture content) while their enthalpies of gelatinisation and retrogradation remain unchanged (Lan et al., 2008). The granule shapes of the studied starches are unchanged while the surfaces of waxy and high amylose increase in roughness, pores, and indentations due to granule swelling (Lan, et al., 2008). Generally, variation in starch crystallinity upon annealing can be influenced by: (1) amylopectin content, (2) average amylopectin chain length, (3) orientation of the double helices (within the crystallites) to X-ray beam, (4) crystallite size and (5) starch moisture content (Lan, et al., 2008). Regarding the resultant wheat starches after annealing, increasing in crystallinity can be observed and it relates to several factors: (1) an increase in crystal perfection, (2) formation of new crystallites formed by interaction between (amylose-amylose, amyloseamylopectin, amylopectin-amylopectin) starch chains, (3) increase in crystallite size and (4) crystallite reorientation (Lan, et al., 2008). Annealed wheat starches show increasing in $T_{0}$, $T_{p}, T_{c}$ and decreasing in $T_{c}-T_{0}$ which due to perfection of pre-existing crystallite without no new double helices formation (enthalpy of gelatinisation remain unchanged) (Lan, et al., 2008). Annealing of wheat starches show reduction in amylose leaching which can be influenced by (1) total amylose content, (2) extent of interactions between amylose and/or amylopectin chains, and (3) amount of lipid complex amylose chain (Lan, et al., 2008). The reciprocal result is found for swelling study. The swelling factor of annealed wheat starches are decreased due to increasing of crystalline perfection as well as interaction between amylose and/or amylopectin chains (Lan, et al., 2008). Pasting properties (peak, breakdown, final and setback viscosity) of annealed wheat starches are found to reduce but increase in peak time comparing to their native counterparts. This result reflects a consequence of reduction in amylose leaching and swelling factor (Lan, et al., 2008). The researchers remark that their results are different from other studies (in wheat starch) because the variation of annealing temperature that applied for each study (Lan, et al., 2008). According to the 
reduction in setback viscosity, annealing seems to be a promising technique to improve thermal stability of starch which is an advantage for industrial process (e.g. canned food, frozen food, rice noodle) (Jayakody \& Hoover, 2008). Similar results are reported in annealing study of barley starches (Waduge, et al., 2006). It is interesting that barley starch show transition of $X$-ray pattern from a pure $A$-type to $A+B$ type crystal upon annealing (Waduge, et al., 2006). This is suggested to be due to increasing in amylose content in the granules after annealing and the transition could occur at 33\% amylose (for barley starch and $40 \%$ for corn starch) (Waduge, et al., 2006). The effect of annealing on X-ray pattern is more pronounced for B-type starch than A-type (Jayakody \& Hoover, 2008).

As illustrated figure 2-13, annealing can be explained by semi-crystalline polymer approach as: (1) a sliding diffusion, which entails the movement of complete molecular sequences within a crystalline lattice (favoured by high mobility of the chains in the crystals) and/or (2) a complete or partial fusion of crystals and subsequent recrystallisation of the melted materials at annealing temperature (Jayakody \& Hoover, 2008). In the dry state, double helices of starch exist but not arranged side by side due to the difference lengths of radial and tangential branches. This state is called "nematic." Amorphous areas are glassy prior to hydration, and are the zone where water absorption and plasticisation initially occur (Jayakody \& Hoover, 2008). The hydration of starch granule increases mobility of the amorphous regions and thus induces vibration movement in both amorphous and crystalline domains. An increase in annealing temperature $\left(>T_{g}\right.$ but $\left.<T_{0}\right)$ and excess water accelerate the rate of hydration and increase glucan chain mobility. This dynamic nature allows limited side by side movement of the double helices, resulting in the formation of smectic-type structure (Jayakody \& Hoover, 2008).

Figure 2-14 could be the most appropriate schematic diagram to synopsise starch-water interactions, phase transition occurring to starch at different temperature. 


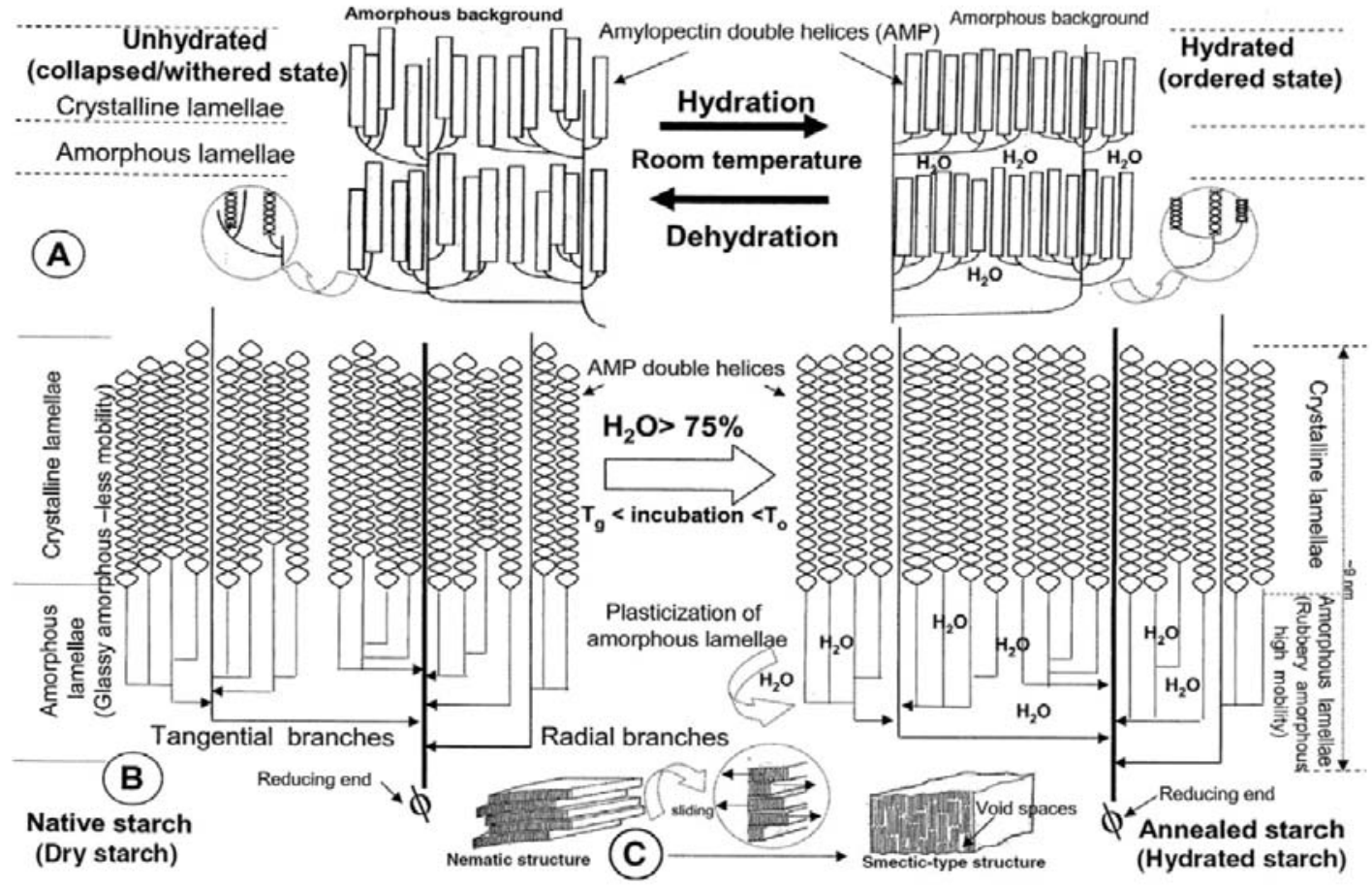

Figure 2-13: Mechanism of annealing (Jayakody \& Hoover, 2008)
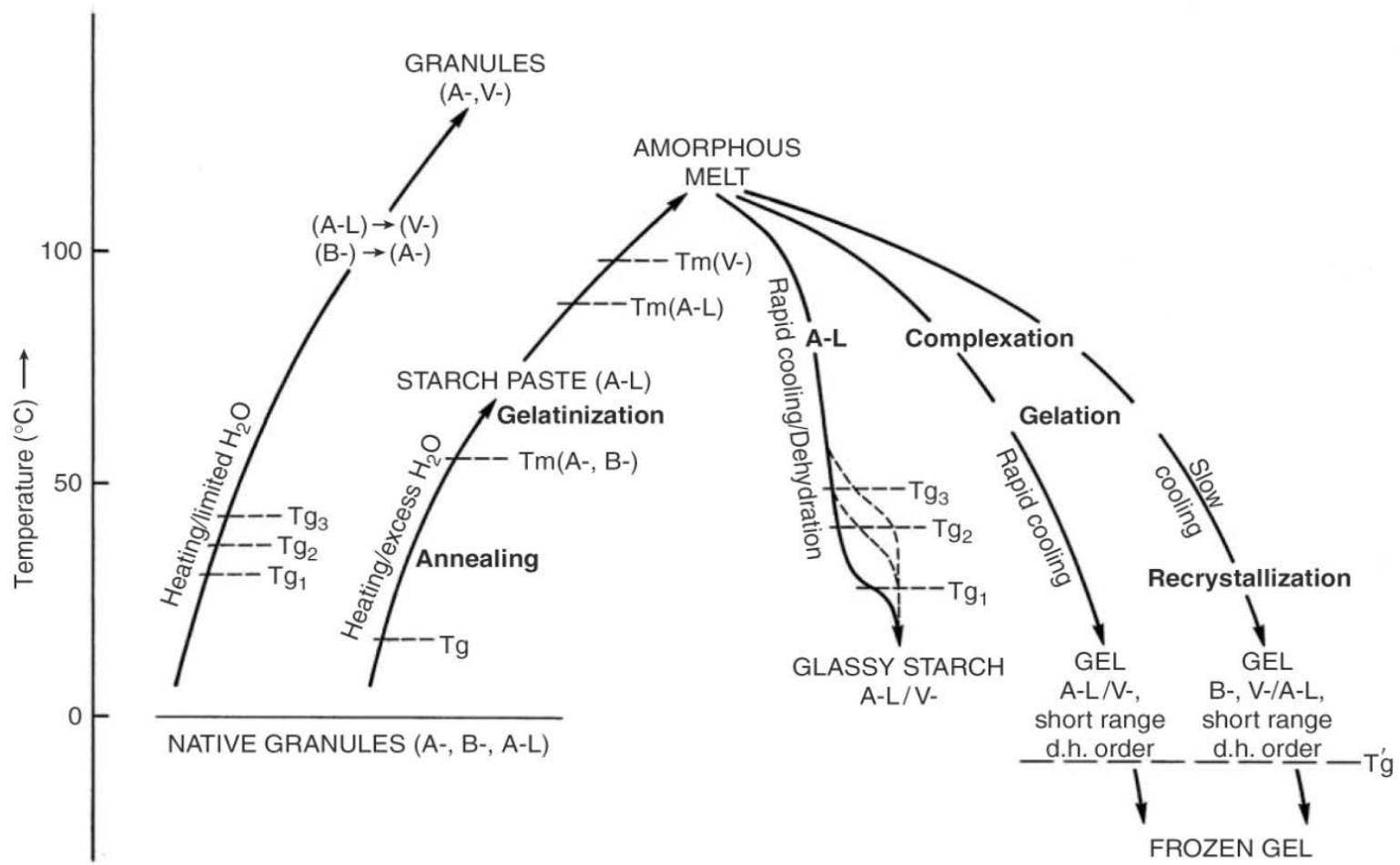

Figure 2-14: Schematic diagram of state and phase transition of starch, note the effect of moisture content and time on the various stages. $T_{g} 1, T_{g} 2$, and $T_{g} 3$ represent the glass transition at different moisture content levels. A-L and V-structures denote short- and longrange order of amylose-lipid complexes, whereas d.h. (double helices) order corresponds to short-range B-type structures (Biliaderis, 2009). 


\subsubsection{Flavour in food}

\subsubsection{Flavour retention and release}

Flavour is important in food organoleptic properties. It is not only showing the identity of food but also reflects the quality of food. Food flavour influences consumer perception and preference. The term "flavour" is used for describing the integrated perception of all of the contributing senses; smell, taste, sight, feeling, and sound at the time of food consumption (Lindsay, 1996). Humans are able to sense the taste molecules as sweetness, sourness, saltiness, bitterness and umami by the buds on the tongue and the back of the oral cavity. In term of feeling (from sensory molecule), there are pungency, cooling, and astringency (Lindsay, 1996). Indirect senses (sight, sound, and feeling) or nonchemical influence the perception of tastes, smell and food acceptance (Lindsay, 1996). Food odour involves odour perception, which is very complicated due to numerous numbers of aroma compounds. Foods may carry either one or few flavour compounds or for particularly processed food, complex flavour compounds mix. Flavours and odours are formed and developed during processing. For example, caramel odour consists of several compounds e.g. pyrazine, furan, and they are associated with thermally-induced or browning reaction during baking, grilling or roasting (Lindsay, 1996). The term "flavour" in this review is dedicated to "aroma" compounds and the attention is intensively paid to the interaction between aroma, starch and water.

Flavour compounds are volatile therefore they are easily altered by poor handling or inappropriate storage. Uncountable researches have contributed to the study of food flavour in order to find out flavour profile in various types of food, to preserve or enhance flavour in food matrices, and create new flavour compounds etc. Flavour study relies on the interaction of flavour compounds in food matrices.

Considering flavour interactions in food, mainly two types have been extensively described in the literature as attractive and repulsive. Attraction correspond to a binding of volatile compounds on non-volatile substrate while repulsive is a release (Le Thanh, Thibeaudeau, Thibaut, \& Voilley, 1992). There are three physical chemistry approaches to understand flavour interactions in food systems. The first one is the characterisation of flavour molecules partition between phases. The second is the analysis of the transport mechanisms where the flavours compounds are carried to food matrices via diffusion or other transport means. The last one is the study of flavour molecule binding to food 
component (Taylor, 1998). The binding of flavour compound depends on the type of compounds and matrices. Irreversible covalent bonds may exist between ketone and aldehyde compounds with amino acid and proteins. Polar compounds such as alcohols interact with substrate via hydrogen bonds while apolar volatile compounds bind with amylose helix and protein via hydrophobic interactions. The last interaction is formation of inclusion complex (Boutboul, Giampaoli, Feigenbaum, \& Ducruet, 2002; Le Thanh, et al., 1992). Regarding interaction between starch and flavour, only 2 types of interactions can be taken into account: polar interactions (hydrogen bonds between the hydroxyl groups of starch and aroma compounds) and inclusion complexes (the flavour compound is entrapped in amylose helix through hydrophobic bonding (Boutboul, et al., 2002).

Like the binding of flavour compounds to food matrices, flavour delivery also depends on several factors, more particularly the availability of the flavour compounds in the gas phases and the affinity of the flavour compounds for the food matrix (Druaux \& Voilley, 1997; Ruth \& Roozen, 2010). Food systems are complex and usually consist of several components. Various parameter affect flavour release e.g. molecular size, functional groups, shape and volatility (Van Ruth \& Roozen, 2010). Molecular weight, vapour pressure, boiling point, and partition coefficient $(\log P)$ are key parameters for volatility studies of the compounds under static conditions (Van Ruth \& Roozen, 2010; Van Ruth, O'Connor, \& Delahunty, 2000). Preininger (2006), summarised the interaction of flavour-food interaction in a diagram presented Figure 2-15.

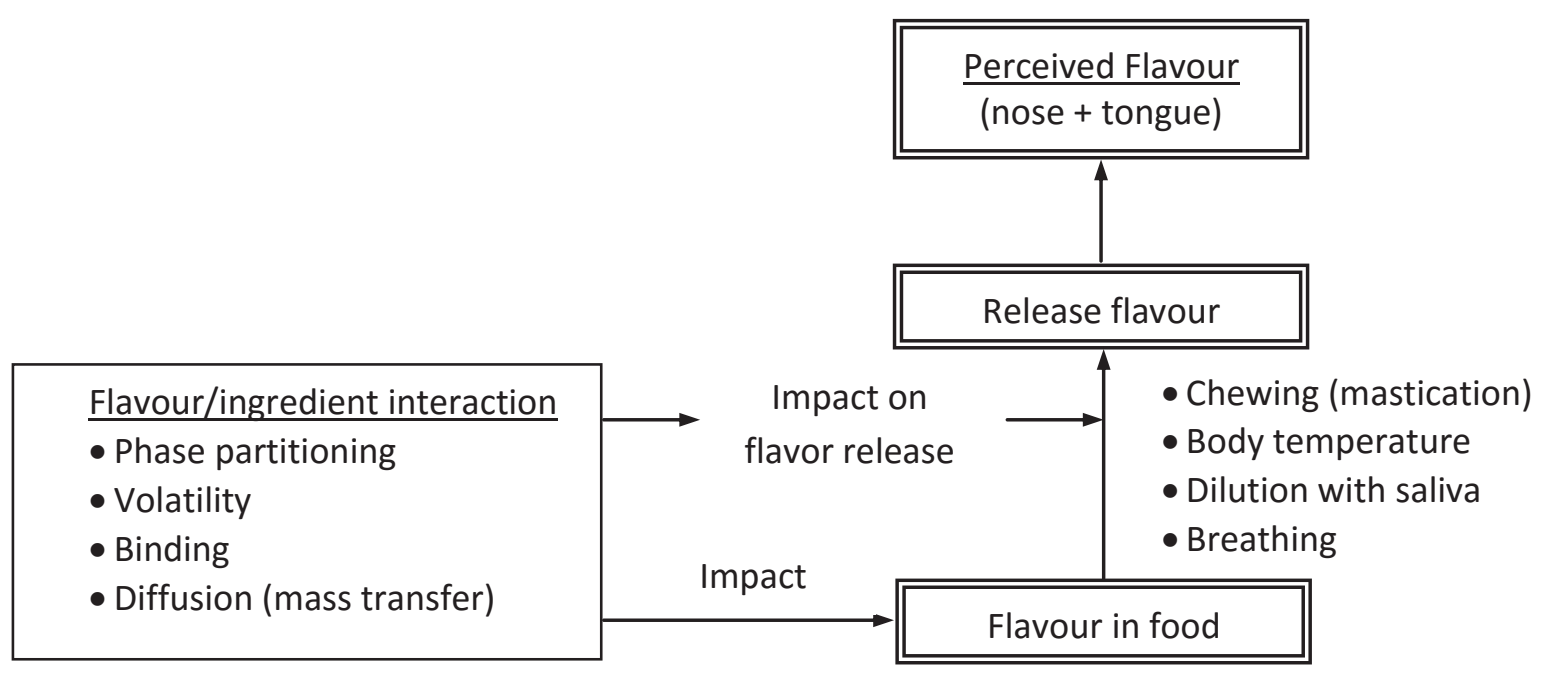

Figure 2-15: Flavour-food interaction diagram (Preininger, 2006) 
Although there are several parameters involved in flavour release, it can be mainly explained by two principles either static or dynamic (Preininger, 2006). Static release occurs between the different phases of a product comprising a solid food matrix (e.g. starch, cellulose), a hydrophilic liquid phase (water) or lipophilic liquid phase (oil) and gas phase (air). Partition coefficients of the flavour molecules impact their volatility and thus play an important role in the release control between phases (Preininger, 2006; Van Ruth, et al., 2000). Dynamic release occurs when the equilibrium is disturbed such as by chewing. It is influenced by food texture and controlled by the diffusion (mass transfer) rate of the flavour molecules through the matrix and its interfaces (Preininger, 2006). The matrix viscosity has a strong influence on flavour retention and release. Highly viscous foods particularly when they contain substantial bulk phase, the flavour release occurs more slowly than liquid foods (Preininger, 2006). Viscosity is a key parameter for flavour release, it occurs more slowly in highly viscous food than liquid ones.

Once flavour is released, it is generally expected to be perceived. Flavour perception relies on several factors: first, flavour compounds should be volatile, second, they should be able to reach "the consumer" olfactory system, and finally the intensity of the compounds should reach the threshold of human perception. These factors depend on the volatile stability, volatility and consumer's sensitivity (which varies among population) (Lindsay, 1996; Rowe, 2005). The statement of Professor W. Grosch at the Weurman Flavour Symposium of 1998 in Farching, Germany, emphasises the importance of flavour stability (Winkel, 2005): "All flavours could be made from only 200 different molecules if only those 200 molecules were stable" (Winkel, 2005). Flavour stability depends on: (1) the stability of the flavour itself; (2) its stability in food; (3) flavour changes either during processing or storage (Winkel, 2005).

The physical parameters influencing flavour stability: (1) evaporation of the volatile components; (2) crystallisation of non-soluble material (only in liquid flavours); (3) phase separation; (4) solubility (e.g. in fat-containing food); (5) absorption and absorption effect (with a complicated food matrix) (Winkel, 2005). Chemical parameters also affect flavour stability: reaction of food components; reaction of flavour components (e.g. through degradation, rearrangement and/or oxidation) (Winkel, 2005). 
Flavour perception depends on: 1) presences of flavour in the matrix but also 2) allows release. Flavour-matrix interactions must be strong enough to preserve flavour in the food and flavour compounds need to interact in suitable manner that favours the release.

\subsubsection{Starch-flavour interaction}

When starch is presented as the food matrix, the concerned flavour interacts with the matrix through binding. The structure of starch allows it to have two different types of binding: flavour inclusion complexes and polar interactions (Arvisenet, et al., 2002; Boutboul, et al., 2002; Conde-Petit, et al., 2006; Nuessli, Conde-Petit, Trommsdorff, \& Escher, 1995). Conde-Petit, Escher et al., (2006) described flavour binding through nonspecific and specific binding. The interactions through sorption are of non-specific type whereas they are specific ones through starch inclusion complex. Aroma-starch adsorption occurs through hydrogen bonding and is strongly influenced by the polarity of flavour molecules (Boutboul, et al., 2002). Flavour binding and release rates are different depending on the ingredients present in the matrices. Viscosity and moisture content have proved to be factors affecting flavour binding and release (Druaux \& Voilley, 1997; Le Thanh, et al., 1992).

Various researches have been carried out in order to get a better understanding of starch-flavour interactions. However the experimental conditions vary with each work (type and quantity of starch and flavour, preparation and storage...), it thus remains difficult to have a general rule enabling one to understand the starch-flavours interactions as a whole. As early described in structure of starch and its chemistry, starch behaves differently when its structure has been altered. Hence flavour retention and release are different at each state. Among the key factors, the availability of water in the studied systems should also be considered since it has been shown to affect flavour solubility and thus release (Roos, 2010).

\subsection{Interaction between flavour and granular starch}

In the dry state, native starch granules physically adsorb flavour to their porous surface via hydrogen bonding (Escher, Nuessli, \& Conde-Petit, 2000). The humidity of the system affects flavour release and retention as it is directly associated with phase partition (Boutboul, et al., 2002) as well as molecular mobility. The type of starch is also 
important for flavour interaction (binding and evaporation rates) due to difference in granule surface area, surface properties and channel presents (Jørgensen et al., 2012). Jørgensen et al. (2012), found that thermal properties of 3 types of native starch (potato, maize and pea) are changed upon incubation with flavour compounds (without heating). The researchers suggest that interaction between starch granules and ligand molecule result in disruption or creation of helices and crystalline material in the granules. The incubation with flavour compounds induce different effects on thermal behaviour depending on type of starch and structure of flavour compounds (Jørgensen, et al., 2012).

In fat-containing food matrices, fat content is a major element affecting flavour retention. The lipophilic flavour compounds are likely to be retained when the fat content is increased (Arancibia, Jublot, Costell, \& Bayarri, 2011). Boutboul et al., (2002) showed that flavour retention in any types of starch-based matrix increased with increasing flavour polarity. Indeed starch serves as a polar stationary phase and can form hydrogen bonds with those polar flavour molecules. Granular and native starches are less capable to retain flavour since their structure in granular form limits accessibility for flavour (Boutboul, et al., 2002). The structure of starch granule influences flavour retention as Boutboul et al. (2002) reported that granular starch had less ability to retain aroma compared to its extruded form.

The surface area has been shown to also play a key role (Boutboul, et al., 2002; Hau, et al., 1998): the higher the specific area, the greater the flavour retention. In spite of the role of amylose through the complexation, it was shown that the retention tended to rely on specific area rather than amylose content. The specific retention of aroma compounds was found to increase in pre-gelatinised starch and maltodextrins after lossing granular structure. It is greater in maltodextrins than in pre-gelatinised starch due to their higher specific area. Similarly, Hau et al. (1998) showed that grinding extruded samples increased their surface area which gave rise to binding capacity. Inclusion complexes with aroma were unable to form under sub- $\mathrm{T}_{\mathrm{g}}$ conditions (temperature and humidity) due to too low mobility for amylose molecules (Boutboul, et al., 2002). According to glassy state conception, it is speculated that flavour retention in glassy foods should be significantly higher compared to food in rubbery state since molecular motion is smaller (Hau, et al., 1998). However, water content and surface are involved in controlling volatile binding capacity to starch under glassy and rubbery state. The glassy state affects binding to starch 
when the surface area is large but has less effect when the surface area is small (Hau, et al., 1998). The presence of emulsifier has been shown to facilitate flavour retention in native starch-water suspension (5-40\% starch) (Lopes da Silva, Castro \& Delgadillo, 2002).

\subsection{Interaction between flavour and starch under hydrothermal}

treatment

In heat treated starchy matrix with high water content, suitable ligand (lipid, flavour, iodine...) are able to form amylose-inclusion complex (Putseys, Lamberts, \& Delcour, 2010). Amylose helices provide hydrophobic cavity for ligand molecule to fit in (Putseys, et al., 2010). According to Biliaderis et al., (1986) granular lipids are able to form helical inclusion complexes with amylose. In addition to formation of amylose-lipid complex, DSC results exhibited that the formation takes place simultaneously and immediately after the onset of thermal events associated with melting. Gelatinisation enthalpy of defatted starch is found to be greater than for native one or defatted starch heated in presence of monoglycerides: this emphasises that the complex formation followed by its crystallisation occurs exothermally and thus decreases gelatinisation enthalpy (Biliaderis, et al., 1986). Formation of flavour-inclusion complex is similar to amylose-lipid complex, due to the structural similarity of certain flavour molecules with some fatty acids (Jouquand, Ducruet \& Le Bail, 2006). The inclusion complexes are formed during gelatinisation of starch (Biliaderis, 1992; Biliaderis, et al., 1986; Jang \& Pyun, 1996) and their melting can be observed by DSC immediately after the onset of thermal events (gelatinisation and melting of starch crystallites). Numerous publications suggest that formation of inclusion complexes occurs when amylose containing-water starch suspensions, particularly, interact with fatty acids or flavour (Fanta, Shogren, \& Salch, 1999). The degree of amylose-lipid complex formation increases as increasing of amylose chain lengths, which may also apply for flavour-starch complex (Godet, Bizot, \& Buléon, 1995).

Starch, and more particularly amylose, is known to complex with iodine: therefore, iodine assay is used as a method to analyse and quantify inclusion complex (Heinemann, Zinsli, Renggli, Escher, \& Conde-Petit, 2005). Tapioca starch is able to form inclusion complex with primary, secondary alcohol, and ketone compounds (Itthisoponkul, Mitchell, Taylor, \& Farhat, 2007). A classical model of amylose-lipid complex is shown in Figure 2-16 (Buléon, et al., 1998). The helical structure of amylose provides a cavity for the 
guest molecule to sit in. The complex is stabilised by hydrophobic interactions (Conde-Petit, et al., 2006; Heinemann, et al., 2005) while intermolecular bonds such as van de Waals forces and hydrogen bonds (between helix turns) stabilise a single helix chain (Putseys, et al., 2010). Conformational orientation of starch is suitable to entrap the lipophilic molecule since starch turns its hydrophilic parts outside and keeps hydrophobic ones inside. The formation of starch-flavour inclusion complexes is a reversible process. Another model of the possible location of the ligand widely accepted (Figure 2-17) suggests that the guest molecules are not included within the helix but can be trapped between the helices (Lay Ma, Floros, \& Ziegler, 2011; Nuessli, Putaux, Le Bail, \& Buléon, 2003; Rondeau-Mouro, Bail, \& Buléon, 2004). Upon lipid or flavour interaction with starch, X-ray diffraction evidence that starch structure is altered and it is defined as V-type starch (Godet, et al., 1995; Heinemann, Escher, \& Conde-Petit, 2003; Itthisoponkul, et al., 2007; Jørgensen, et al., 2012; Nuessli, et al., 2003; Pozo-Bayon, Biais, Rampon, Cayot, \& Le Bail, 2008).

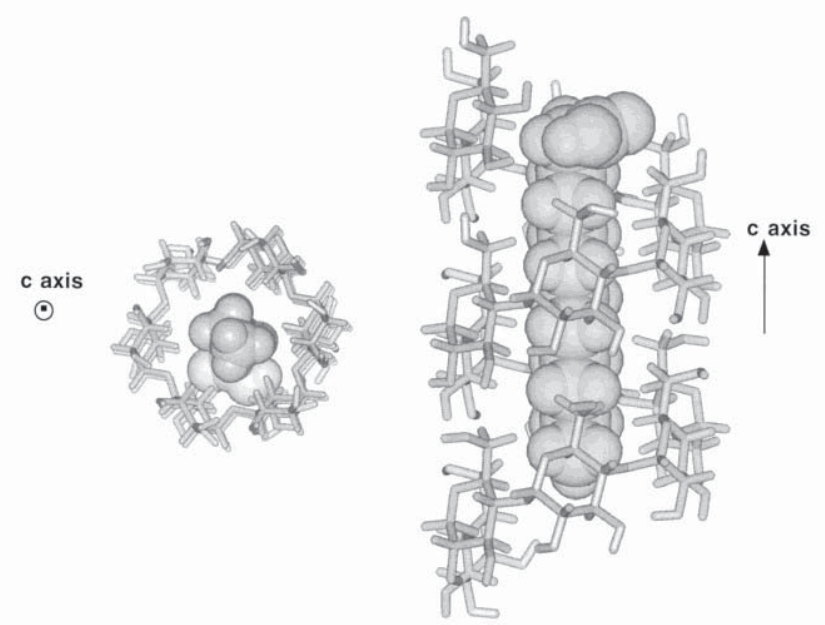

Figure 2-16: Molecular modelling representation of amylose-fatty acid complexes showing the inclusion of the aliphatic part (C12) of fatty acid inside the hydrophobic cavity of the amylose single helix (Buléon, et al., 1998).

Arvisenet et al. (2009) studied starch-flavour interaction in potato starch and three types of flavour compound. They focused on structural interaction and ability to form inclusion-complex. Wide-angle X-ray diffraction and DSC were applied as the study technique. Figure 2-18 shows a wide angle X-ray diffraction diagram of amylose-isoamyl acetate. The reflections at $2 \theta=5.3^{\circ}, 14.6^{\circ}, 17^{\circ}, 22^{\circ}$, and $24^{\circ}$ are characteristics of the $B$ 
type retrograded amylose. This result indicates that amylose did not form complexes with isoamyl acetate. X-ray diffraction diagrams of amylose precipitated with ethyl hexanoate and linalool are shown in Figure 2-18b,c. The reflections at $2 \theta=6.7^{\circ}, 12.5^{\circ}$, and $17.8^{\circ}$ are comparable to those obtained for amylose complexed with 2-propanol (Arvisenet, et al., 2002; Buléon, et al., 1998). With linalool the crystallinity seems to increase. The reflections are quite sharp, although the formation of the precipitate was very fast, which is usually an indication for a less organised system (Arvisenet, et al., 2002).

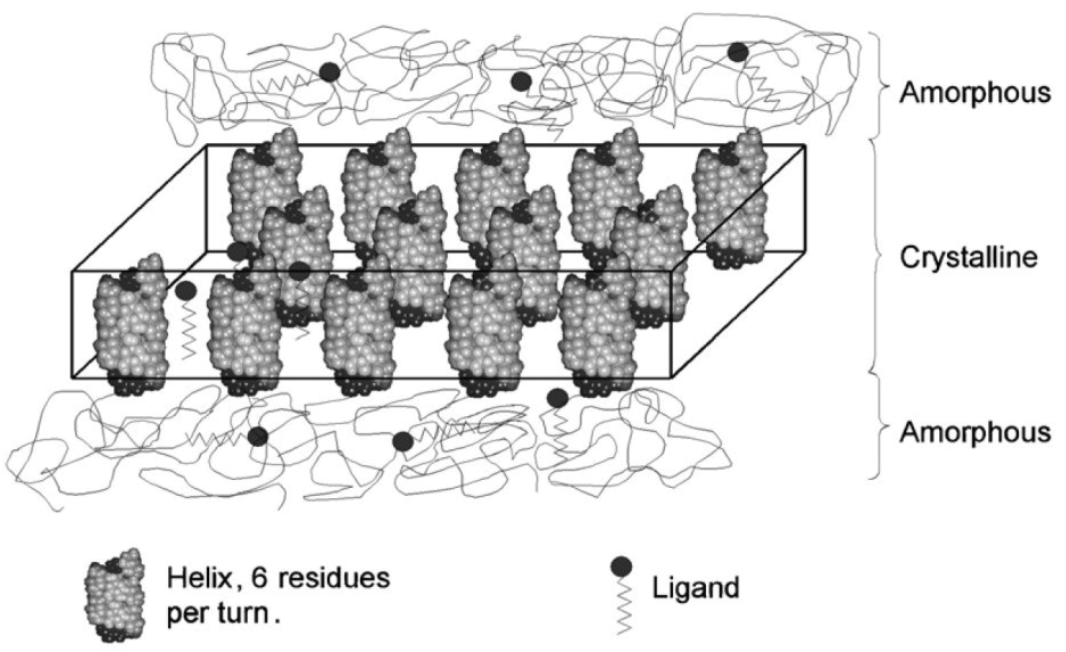

Figure 2-17: Schematic representation of the structure of amylose-aroma complexes and possible location of the molecules trapped in the amorphous phase (Biais, Le Bail, Robert, Pontoire, \& Buléon, 2006).

The crystalline structure and thermo stability of amylose complexes, are commonly called "V type". Most $\mathrm{V}$ amylose structures are made from six fold or, to a lesser extent eightfold, left-handed helices. They can therefore be classified into two families (V6 and V8) where 6 and 8 represent the number of D-glucosyl units per turn. In the V6 family, three types of crystalline packing $\mathrm{V}_{61}, \mathrm{~V}_{6 I I}$, and $\mathrm{V}_{6 \mid I I}$ (where I, II, and III define unit cells of different sizes) may be obtained depending on the nature of the complexing molecule. The complexing molecule can be trapped either in the single helix only $\left(V_{61}\right.$ or $\left.V_{h}\right)$ or both within and between amylose helices ( $\mathrm{V}_{6 \|}$ or $\mathrm{Vbutanol}$ and $\mathrm{V} 6 \mathrm{II}$ or $\mathrm{V} 2$-propanol) (Pozo-Bayon, et al., 2008). As mentioned earlier ethyl hexanoate is able to form inclusion complex with starch classified as $\mathrm{V}_{6 I I}$ (Arvisenet, et al., 2002). 
The retention rates of flavour compounds entrapped in the amorphous zones are lower than the complexed ones (Jouquand, Ducruet, \& Le Bail, 2006). It depends on both carbohydrate type and flavour properties. The retention of flavour compounds seems to be linked to the hydrophobicity of flavour compounds with some exception (e.g. 1hexanol) (Jouquand, Ducruet, \& Giampaoli, 2004). 2-Hexanone for instance, is better retained in $\beta$-cyclodextrin than in maltodextrins due to the differences in hydrophobicity of the systems (Jouquand, et al., 2004). The studies of amylose-inclusion complexes have shown that increasing water solubility through a change of degree of substitution decreased degree of complex formation (Wulff, Steinert, \& Höller, 1998).

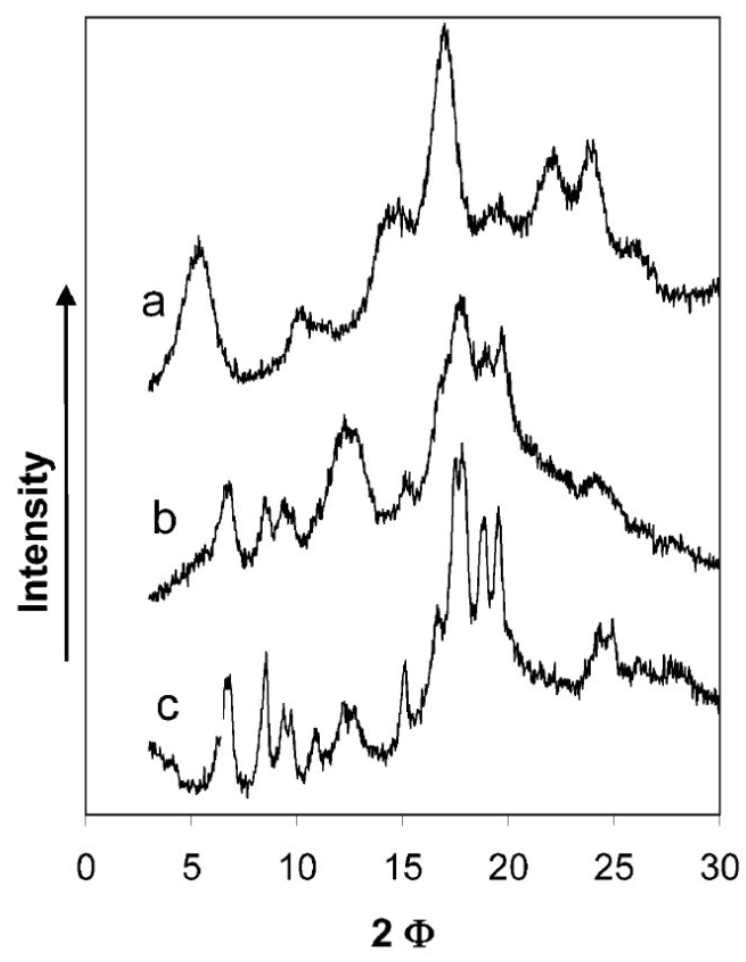

Figure 2-18: X-ray diffractograms obtained from crystals of amylose with isoamyl acetate (a), linalool (b) and ethyl hexanoate (c) (Arvisenet, et al., 2002).

Matrices containing starch give better aroma retention than other texturing agents (Arvisenet, et al., 2002). The inclusion complex is believed to provide protection during processing particularly gelatinisation and storage (Hau, et al., 1998; Heinemann, et al., 2001; Nuessli, et al., 1997). Although starch-flavour inclusion complex is similar to starch-lipid complex in terms of structural orientation and thermoreversibility, 
various researches have shown by DSC that there are two types of complexation: type I and type II. The type I complex is of amorphous form (unordered form) while the type II is crystalline. When the amorphous initially complexes are organised in lamellae and give rise to the formation of crystallites, they are referred to as type II amylose-inclusion complexes (Itthisoponkul, et al., 2007; Karkalas, Ma, Morrison, \& Pethrick, 1995; Putseys, et al., 2010).

The difference between these two types can be distinguished by DSC according to their melting behaviours. Type I melts at lower temperature than type II (Itthisoponkul, et al., 2007; Karkalas, et al., 1995). However, the melting temperature depends on type of ligand molecule and study conditions (Itthisoponkul, et al., 2007): the longer the carbon chain length of the ligand, the higher the melting temperature.

Functional groups and their position play an important role in the formation and stability of both types of complexes. Primary alcohol and ketone are able to form type I and II complexes. It was found that the position of functional group ex. 1nonanol, 2-nonanol, 3-nonanol, influence the type of complexes formation as well as its stability (Itthisoponkul, et al., 2007). Heinemann et al., (2005) revealed that flavour inclusion complex can be formed when the ligand compounds are added at excess concentration, a lower ligand concentration formation of amylose-complex in aqueous dispersions may lead to the build-up of partly crystalline structure, i.e. spherulites (Conde-Petit, et al., 2006). The spherulites are composed of amylose and can grow up to a size of $100 \mu \mathrm{m}$ (Conde-Petit, et al., 2006). Spherulites formation can be controlled not only by ligand but also starch concentrations and time-temperature conditions (Conde-Petit, et al., 2006). Upon thermal process, the amylose network dissociates, blends with flavour compound, reforms a network as gel and results in inclusion complex, however high concentration of amylose and amylose leaching may lead to self-assembly and induce spherulites formation (Conde-Petit, et al., 2006; Heinemann, et al., 2005; Putseys, et al., 2010). The excessive amount of ligand molecule facilitates the dispersion of amylose and could disturb self-assembly in the food model system (Heinemann, et al., 2005). The suitable concentration of ligand depends on type and structure of ligand (Lebail, Buleon, Shiftan, \& Marchessault, 2000; Putseys, et al., 2010). At lower ligand concentration amylose may form double helix and compete with single helix to form the complex (Putseys, et al., 2010). Although several researches suggest that flavour inclusion complex is formed upon the conditions that favour gelatinisation conditions, it is found that inclusion complex can be formed under heat-moisture treatment 
with moderate ( $40 \%$ moisture content) and low moisture content ( $25 \%$ moisture content) (Derycke et al., 2005).

Starch-lipid complex and expectedly starch-flavour ones are reported to decrease starch swelling capacity, solubility and granule disruption and increase gelatinisation temperature (Putseys, et al., 2010). In case of interaction with ligands, different effects on starch gel and viscosity are reported to depend on ligand chain length, concentration, amylose content, water content, and polarity of ligand (Putseys, et al., 2010).

\subsubsection{Study of starch structure and interaction and study techniques}

Structure of starch either native or after treatment is complex in itself. It is important to understand the structure in profound since the physical properties of starch derives from its structure. Food structural feature is getting more important at industrial level since it is a key in food research development and innovation to understand form, function and to control organoleptic properties (Blazek \& Gilbert, 2011; Copeland, et al., 2009; Ubbink \& Mezzenga, 2006). Like the structure of starch, gelatinisation is a complex phenomenon since there are several processes occurring simultaneously. Various aspects of study have been done on starch, hence several techniques have been employed to obtain the most appropriate information. A unique approach is not sufficient to explain such a complex phenomenon occurring in the starch granule. DSC alone cannot explain the whole changes particularly when this depends on study conditions (temperature, sample preparation, water content, heating rate) (Oostergetel \& van Bruggen, 1993; Ratnayake \& Jackson, 2007; Ratnayake, et al., 2008).

Although numerous profound studies of starch structure have been carried out this research domain remains under investigation as the advance in technologies and instruments brings about higher sensitivity of measurement, more details or even new findings. Structural study is now possible from granular to molecular level. Some structural features and techniques are summarised in Figure 2-19. The choice of techniques depends on the objectives of study as well as availability of such instruments.

\subsubsection{Granular level: granulometry}

The techniques employed to study granule size, distribution and surface area vary depending on the instruments available to the investigators. Granule size study relies 
on the principle of particle size measurement. There are several techniques commonly used in particle size measurement, however only certain are suitable for starch. The different measurement techniques result in different value since each particle size characterisation technique based on different particle properties (maximum/minimum length, volume, surface area, etc) (Rawle, 2002). Figure 2-20 shows the different properties used in particle measurement within the same sample measurement (Rawle, 2002). It should be noted that the results comparison should be done for the same particle property measured with the same technique (Brittain, 2001; Rawle, 2002).

Sieves are an old technique which is cheap and suitable for large particles but not for sprays, emulsion adhesive, agglomerated materials. The results possibly deviate due to the shape such as rod form particle (Rawle, 2002). The measurement is difficult for powders under $38 \mu \mathrm{m}$ (Rawle, n.d.). The sensitivity of starch granule size measurement by this technique can be enhanced by fractioning the granules however, error can occur due to granule aggregation (Lindeboom, et al., 2004). Although, wet sieving tends to resolve the problem it leading to low reproducibility (Rawle, n.d.).

Microscopy is an excellent technique since the shape and form of particle can be seen directly. It characterises the dispersion as well as aggregation of the sample. Various types of microscopes are available for granule morphological study (Figure 2-21). The method is cheap and easy. Image analysis can be combined with microscope to facilitate quantification analysis however, it is not suitable for large volume and quality or production control work (Rawle, 2002, n.d.). Moreover, the sample should be homogenous (Lindeboom, et al., 2004).

Coulter counter or electrozone sensing is another promising technique for starch granule study. The technique was derived from red blood cell counting technique. The sample which is dissolved in diluted electrolyte possesses a proportion of electric pulse according to its volume and surface area. The technique yields in number count and volume distribution. The particle or any study cell size then derives from obtained volume and surface area (Rawle, 2002, n.d.). There are some fundamental drawbacks regarding Coulter counter e.g. not suitable for emulsion, powders require suspension in the medium, measurement must be done in electrolyte, not suitable for porous, large and dense particle, etc (Rawle, 2002, n.d.). 


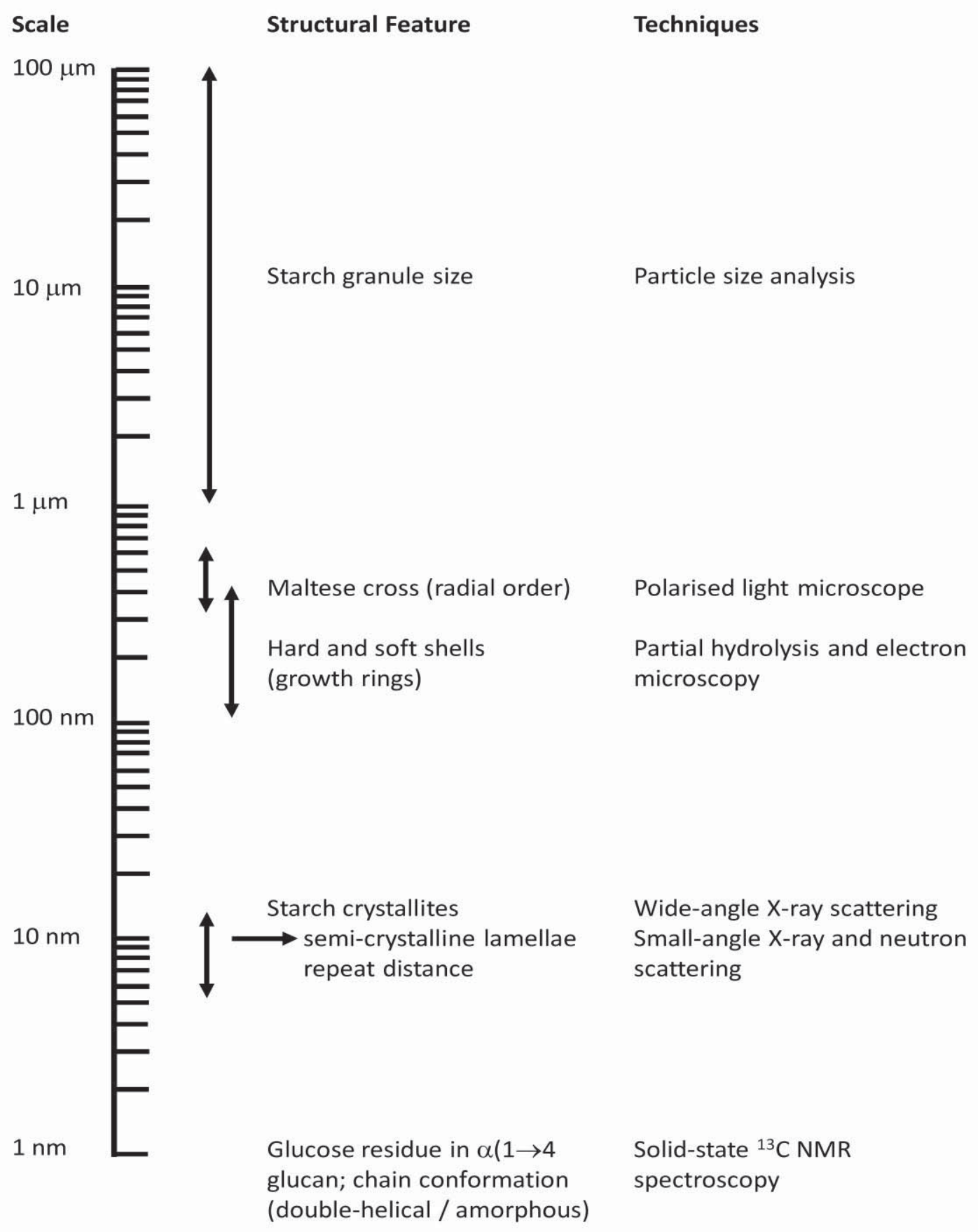

Figure 2-19: Pictorial representation of the length scales within the starch granule together with techniques used to characterise the structural features (Tester \& Debon, 2000) 


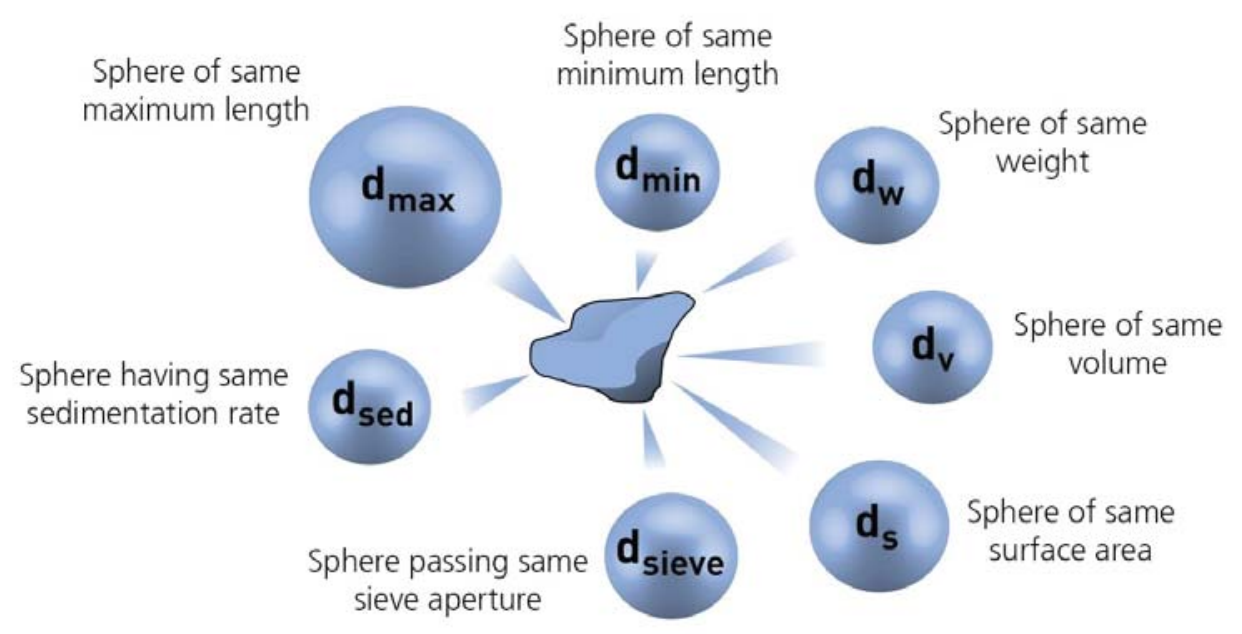

Figure 2-20: Illustration of the concept of equivalent spheres (Anonymous, 2012)

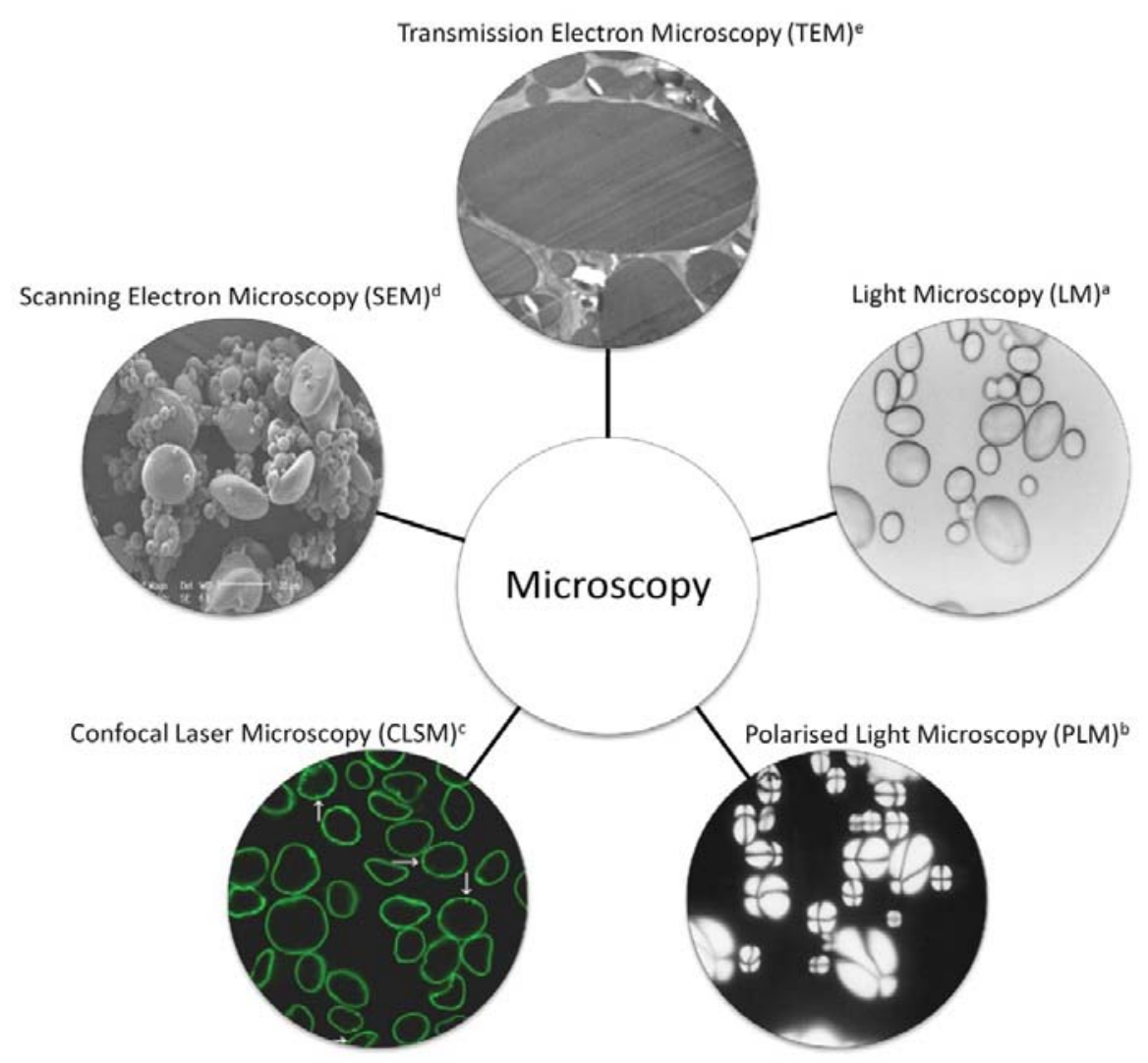

Figure 2-21: Examples of starch granule micrographs from various microscopy techniques; a) \& b) LM and PLM of native potato starch after hydrothermal treatment (magnifying $400 \mathrm{X}$ ) (Vermeylen, Goderis, \& Delcour, 2006), c) CLSM optical cross-section of A-type granules of waxy soft wheat starch isolated via traditional schemes - arrows pointed at granule channels (Kim \& Huber, 2008), d) SEM of unfractionated wheat starch (Sunco variety) (Salman et al., 2009), e) TEM of native wheat starch (Sujka \& Jamroz, 2013) 
Although there are some fundamental drawbacks Warren et. al, (2011) successfully studied starch granule size and distribution using electrical resistance method (Beckman Coulter Multisizer). The study was done on several types of starch including wheat starch. The researchers separated two types of wheat granule by density centrifugation prior measuring the granule size in saline suspensions (Warren, et al., 2011). The results were given as median ( $d$ 0.5) volume diameters $(\mu \mathrm{m})$ were 20.3, 21.1 and 9.8, for wheat, wheat A and wheat B, respectively (Warren, et al., 2011).

Light obscuration (scattering and diffraction) is another common technique to measure starch granule size (Edwards, et al., 2008; Hernandez-Jaimes, BelloPÃ@rez, Vernon-Carter, \& Alvarez-Ramirez, 2013; Kim \& Huber, 2008; W.-y. Li et al., 2008; Malumba, Jacquet, Delimme, Lefebvre, \& Béra, 2013; Naguleswaran, Li, Vasanthan, Bressler, \& Hoover, 2012). The correct terminology of this technique is Lower Angle Laser Light Scattering (LALLS) (Lindeboom, et al., 2004; Rawle, 2002). The name of instruments varied depending on manufacturing company but they are of the same fundamental e.g. Mastersizer, Accusizer, Particle Size Analyzer. This method has become the preferred standard in many industries for characterisation and quality control (Rawle, 2002). Generally, the light source is laser and the principle of measurement based on light blocking which results in scattering and diffraction (Williams \& Carter, 2009). The advantage of measuring granule size by laser light obscuration is the sample preparation since it can be dry or wet depending on the instrument and purpose of study. This technique allows measuring the particles range from nanometres up to several millimetres in size and it is non-destructive. Characteristics (shape, size and distribution) of starch granules from different botanical sources were reviewed elsewhere (Lindeboom, et al., 2004; Tester, et al., 2004). It is mandatory to ensure that there is no aggregation of starch granule prior measuring (Lindeboom, et al., 2004). Advantage, disadvantage and limitation of various techniques to measure starch granule were summarised by Lindeboom et. al, (2004) (Table 2-1) (Lindeboom, et al., 2004).

Granule size measurement based on laser light obscuration is concerned in this study due to its availability in the lab as well as its common use in researches. The principle of instrument is based on laser light diffraction after the particles passed through a focused laser beam. These particles scatter light at an angle that is inversely proportional to 
their size. The angular intensity of the scattered light is then measured by a series of photosensitive detectors.

Table 2-1: Advantages and disadvantages of different granule size determination techniques (Lindeboom, et al., 2004)

\begin{tabular}{lll}
\hline Technique & Positive & Negative \\
\hline Microscopy & In situ analysis morphology data & Laborious \\
- Light Microscopy & Morphology data & Undamaged starch prerequisite \\
- IAOM & Detailed morphology data & Homogeneous sample needed \\
& & Limited differentiation with non-starch \\
- SEM & & \\
Microsieving & & Affected by aggregation \& shape \\
Electrical resistance & Unaffected by shape \& density & Low efficiency \\
Laser light scattering & Evaluation till $0.1 \mu \mathrm{m}$ & Undamaged starch prerequisite \\
& & Affected by shape \\
Field flow fractionation & Fractionation high resolution & Undamaged starch prerequisite \\
\end{tabular}

It is common that particle sizes within the same sample vary. The distribution and statistical technique are employed for the calculation of particle size. The size measurement by image analysis and counting give a number of weighted distributions. Laser diffraction which is one of the static light scattering techniques gives a volume weighted distribution. It refers to contribution of each particle in the distribution relates to the volume of that particle (Anonymous, 2012). The different techniques result in different means which affect the interpretation of result. The interpretation of particle size distribution data relies on statistical parameters:

- mean - average size of a population

- median - size where $50 \%$ of the population is below/above

- mode - size with the highest frequency

These 3 statistical values are the same and possibly correct when the particles have Gaussian (Normal) distribution. The particle size distribution is often asymmetric therefore mean, median and mode may not always be relevant for result 
interpretation. Depending on the technique and measured properties (e.g. diameter, volume, surface area) (Anonymous, 2012; Rawle, 2002, n.d.). Among these properties, the three most commonly used for particle sizing are:

1. Number length mean $D[1,0]$ or $X n l$

The number length mean or arithmetic mean is important when counting technique is applicable. This mean can be calculated only when the number of particle is known. Measuring the particle size by microscope usually requires this mean.

\section{Surface area moment mean $D[3,2]$ or Xsv}

The surface area mean (Sauter Mean Diameter) is most appropriate when specific surface area is applicable. The $D[3,2]$ is more appropriate when fines particles are present and concerned.

\section{Volume moment mean $D[4,3]$ or Xvm}

The volume moment mean (De Brouckere Mean Diameter) is relevant for several samples when the particle take up the volume. The technique is sensitive in the presence of large particles in the size distribution. The volume moment mean is commonly used for calculation of particle size distribution measurement by laser light diffraction.

The measurement based on volume weighted particle size distribution (e.g. laser diffraction) is often to report parameters based on maximum particle size for a given. The percentiles are defined as XaB where:

$\mathrm{X}=$ parameter, usually $\mathrm{D}$ for diameter

$\mathrm{a}=$ distribution weighting, e.g. $\mathrm{n}$ for number, $\mathrm{v}$ for volume, I for intensity

$B=$ percentage of sample below this particle size e.g. $50 \%$, sometimes written as a decimal fraction i.e. 0.5

\subsubsection{Molecular level: Carbohydrate spectroscopy}

Spectroscopy shortly means the study of the interaction of light and matter. It actually deals with the production, measurement, and interpretation of spectra arising from the interaction of electromagnetic radiation with matter. There are broad range of spectroscopic techniques available depending on type of radiation-matter (e.g. absorption, emission, diffraction) and region of the electromagnetic spectrum (e.g. infrared, ultraviolet, visible, X-ray). The fundamental of spectroscopy relies on duality (particulate and wavelike) which then explains electromagnetic radiation as wave's frequency, wavelength and 
amplitude (Penner, 2010). Light generally interacts with matter in 4 ways: emission, absorption, transmission and reflection or scattering. The matter is energised (excited) by the application of thermal, electrical, nuclear or radiant energy, electromagnetic radiation is often emitted as the matter relaxes back to its original (ground) state. This interaction results in emission spectrum. Absorption spectroscopy is a measure of fraction or absorbed energy or frequency and resulting in absorption spectrum. Certain materials allow light to pass through, the measurement of proportion of transmitted light is transmission spectroscopy. Reflection or scattering occurs when the wave or particles are diffused or deflected by collisions with the particles of the matter.

Spectroscopy is widely used in food analysis for both quantitative and qualitative studies. The choice of methods based on the properties of interest molecule and atomic transition (Table 2-2). X-ray and infrared spectroscopies are concerned in this review since they are decisively used in starch structural study.

Table 2-2: Wavelength regions, spectroscopy methods, and associated transition (Penner, 2010)

\begin{tabular}{|c|c|c|c|c|}
\hline $\begin{array}{l}\text { Wavelenth } \\
\text { region }\end{array}$ & $\begin{array}{l}\text { Wavelength } \\
\text { limits }\end{array}$ & Type of spectroscopy & $\begin{array}{l}\text { Usual wavelength } \\
\text { range }\end{array}$ & $\begin{array}{l}\text { Type of transition in chemical } \\
\text { systems with similar energies }\end{array}$ \\
\hline Gamma rays & $0.01-1 \AA$ & Emission & $<0.1 \AA$ & $\begin{array}{l}\text { Nuclear proton/neutron } \\
\text { arrangements }\end{array}$ \\
\hline X-rays & $0.1-10 \mathrm{~nm}$ & $\begin{array}{l}\text { Absorption, emission, } \\
\text { fluorescence, and diffraction }\end{array}$ & $0.1-100 \AA$ & Inner-shell electrons \\
\hline Ultraviolet & $10-380 \mathrm{~nm}$ & $\begin{array}{l}\text { Absorption, emission, and } \\
\text { fluorescence }\end{array}$ & $10-380 \mathrm{~nm}$ & $\begin{array}{l}\text { Outer-shell electrons in atoms, } \\
\text { bonding electrons in molecules }\end{array}$ \\
\hline Visible & $380-750 \mathrm{~nm}$ & $\begin{array}{l}\text { Absorption, emission, and } \\
\text { fluorescence }\end{array}$ & $380-750 \mathrm{~nm}$ & $\begin{array}{l}\text { Outer-shell electrons in atoms, } \\
\text { bonding electrons in molecules }\end{array}$ \\
\hline Infrared & $0.075-1000 \mu \mathrm{m}$ & Absorption & $0.78-300 \mu \mathrm{m}$ & $\begin{array}{l}\text { Vibrational position of atoms in } \\
\text { molecular bonds }\end{array}$ \\
\hline \multirow[t]{2}{*}{ Microwave } & $0.1-100 \mathrm{~cm}$ & Absorption & $0.75-3.75 \mathrm{~mm}$ & Rotational position in molecules \\
\hline & & Electron spin resonance & $3 \mathrm{~cm}$ & $\begin{array}{l}\text { Orientation of unpaired electrons } \\
\text { in an applied magnetic field }\end{array}$ \\
\hline Radiowave & $1-1000 \mathrm{~m}$ & Nuclear magnetic resonace & $0.6-10 \mathrm{~m}$ & $\begin{array}{l}\text { Orientation of nuclei in an applied } \\
\text { magnetic field }\end{array}$ \\
\hline
\end{tabular}

\section{$X$-ray diffraction/X-ray scattering}

Scattering is the process in which particles, atoms, etc., are deflected as a result of collisions (Williams \& Carter, 2009). Regarding X-ray study, scattering occurs when X-ray photons interact with the electrons of the target element (Dams \& Strijckmans, 2001). Scattering can be divided into 2 types: elastic and inelastic which refer to no loss of energy 
and vice versa. Coherent (Rayleigh) scattering is elastic collision therefore the outcome wavelength remain exactly the same wavelength as that of the incident beam. Incoherent (Comton) scattering is inelastic which photons give up a small part of their energies during collision (Dams \& Strijckmans, 2001). Diffraction is a special form of elastic scattering (Williams \& Carter, 2009). It is a deviation in the direction of a wave at the edge of an obstacle in the patch (Williams \& Carter, 2009). Diffraction is a combination of two phenomena: coherent scatter and interference (Dams \& Strijckmans, 2001). Interference is a phenomenon due to two or more wave-trains cross one another, they result in an instantaneous wave, at the point of intersection (Penner, 2010). Since photons and electrons possess dual property, scattering might best apply to particles and diffraction to waves (Williams \& Carter, 2009).

One property of crystalline material is the high order arrangement which facilitates the diffraction of photons. Once scattering occurs between impinging photons and the loosely bound outer orbital atomic electrons, then a monochromatic beam of radiation falls onto the high atomic density layers, scattering will occur and undergo constructive interference in accordance to Bragg's law (Figure 2-22, Equation 1) (Dams \& Strijckmans, 2001).

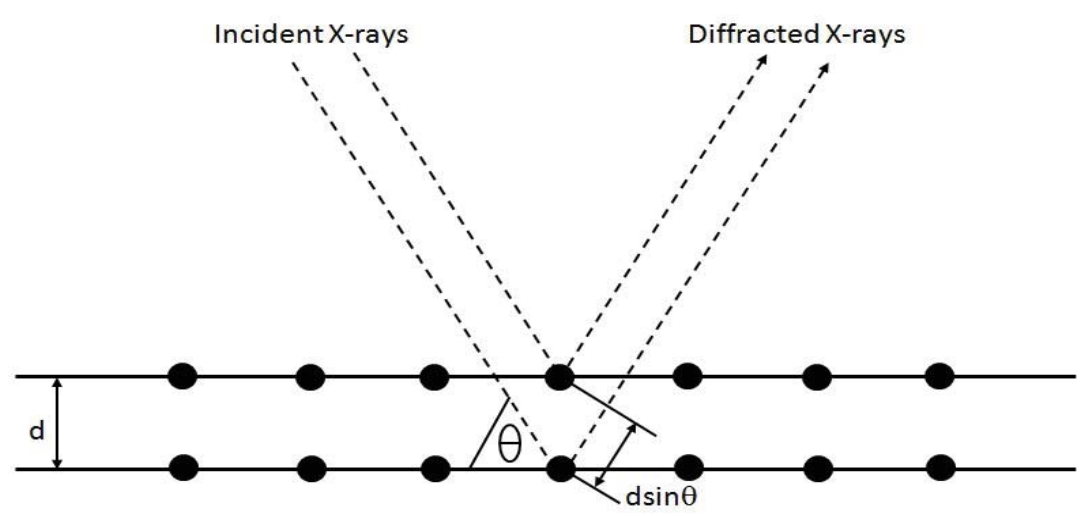

Figure 2-22: Bragg's diffraction (Paulus \& Gieren, 2001)

X-ray scattering and diffraction are both aligned with Bragg's law:

$$
\mathrm{n} \lambda=2 d \sin \theta
$$

(Equation 1)

where $\lambda$ : wavelength

$\mathrm{d}$ : interplanar spacing of the crystal

$\mathrm{n}$ : an integer

$\theta$ : glancing angle (2 $\theta$ : diffraction or scattering angle) 
The diffraction or scattering angle branches the X-ray study into 2 types according to the studied angle: wide and small angles $\mathrm{x}$-ray scattering (WAXS and SAXS). They both are of the same principle. Wide Angle X-ray Diffraction (WAXD) is widely called XRD. XRD and WAXS are the major techniques in structural study, particularly, crystallinity study. XRD is only suitable for crystalline materials whereas WAXS is more flexible on the material range e.g. non-crystalline, proteins. Both techniques are generally regarded as identical. They are not the same but corollary. XRD is conducted in reflection or transmission geometry while WAXS is conducted in transmission geometry (Blazek \& Gilbert, 2011). Regarding study angles (20), XRD and WAXS usually operate between $\sim 8--90^{\circ}$ while SAXS is $<\sim 6^{\circ}$ (Jenkins \& Donald, 1998). SAXS experiment measures the scattering intensity versus scattering vector (q) (Blazek \& Gilbert, 2011).

Scattering vector derives from:

$$
q=\frac{4 \pi}{\lambda} \sin \frac{\theta}{2}
$$

where $\lambda$ : wavelength

$\theta$ : glancing angle

According to Equation 1 and 2, they yield a real space dimension (d), which is derived from:

$$
d=\frac{2 \pi}{q}
$$

where $q$ : scattering vector

The different angles relate to resolution and scale of study. WAXS is used to probe subnanometer dimensions. SAXS is useful for structural determination at low resolution (Blazek \& Gilbert, 2011; Jenkins et al., 1994). Figure 2-23 represents the resolution and scale regarding elastic scattering techniques in starch regarding starch research. Research outcomes from different X-ray techniques are later reviewed. 


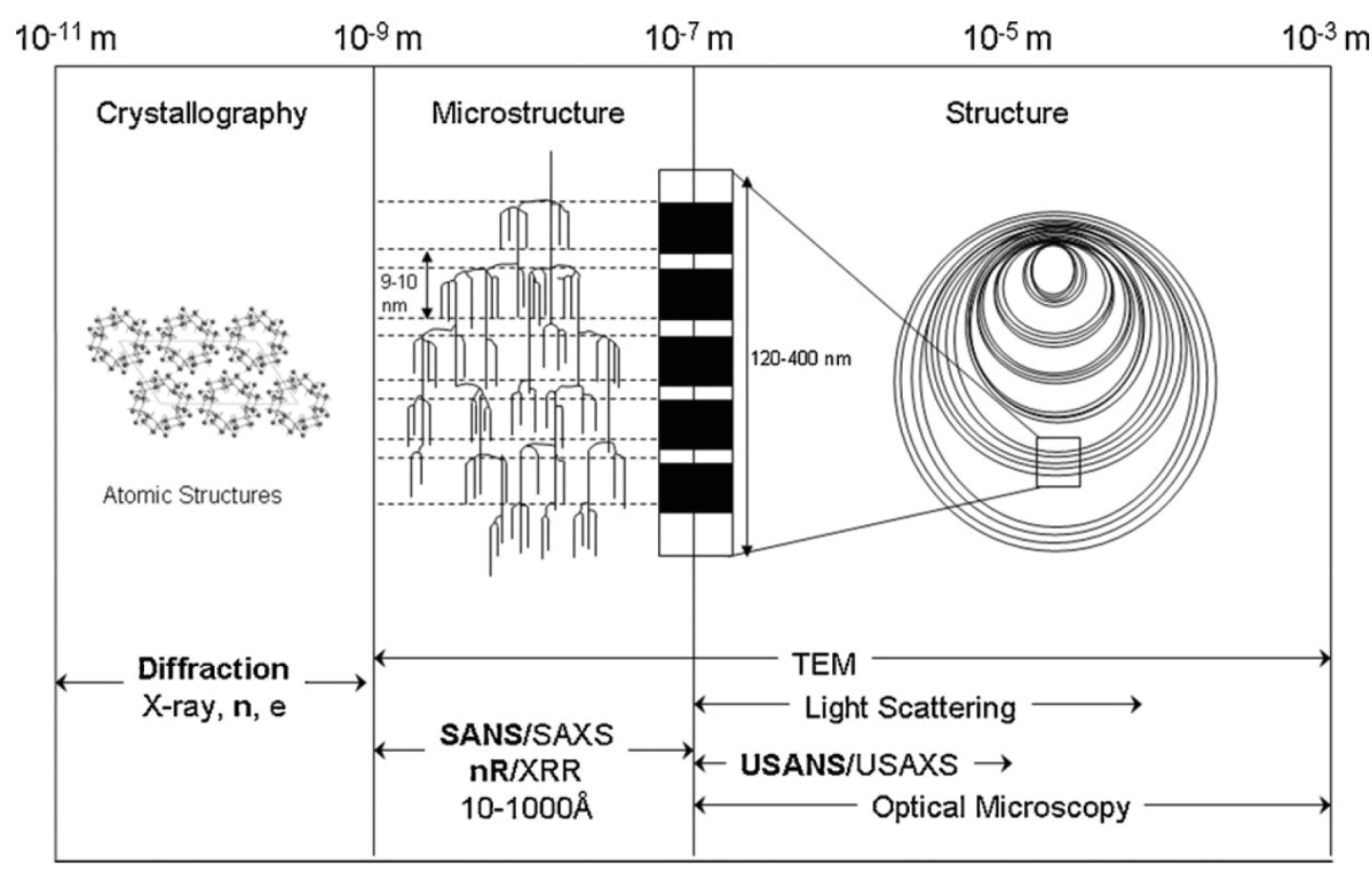

Figure 2-23: The range of elastic scattering techniques, corresponding size range and complementary methods shown in relation to the hierarchical structure of starch; $n=$ neutron; $\mathrm{e}=$ electron; $\mathrm{nR} / \mathrm{XRR}=$ neutron and $\mathrm{X}$-ray reflectometry, $\mathrm{TEM}=$ transmission electron microscopy; USANS/USAXS = ultra-SANS/SAXS (Blazek \& Gilbert, 2011; Lopez-Rubio \& Gilbert, 2009).

X-ray diffraction is a technique to determine crystallinity in term of "absolute or relative" content these refer to internal and external comparison, respectively. Absolute crystallinity differentiates between the amorphous and crystalline component (integrated area) of the X-ray diffractogram. Relative crystallinity relies on calculating the proportion of crystallinity within starch granules using as references, materials with 0 and $100 \%$ crystallinity. The'0\%' reference representing 'fully amorphous' material (e.g. freeze-dried gelatinised material in the present study) with the '100\%'reference usually being generated by extensive acid hydrolysis of starch in which all the amorphous (thus not crystalline) material has been eroded (Buléon, et al., 1998; Tester, et al., 2004). However, native starch can be used as a reference of maximum crystallinity for the samples resulting from the treatment of the native one. Such a technique may be very useful to determine relative crystallinities and compare some starches in the native state or during processes, but may only yield absolute crystallinity if the amorphous and crystalline standards have a true 0 and 
$100 \%$ crystallinity. The methods based on internal reference are used for determination of absolute crystallinity but there are such discrepancies in the published values that it is difficult to rely on such values. The values vary from 15 to $45 \%$ depending not only on the origin and the hydration of starch but also on the technique used. In any case, the crystallinity has to be determined at a well defined hydration since it has been proved to depend strongly on it (Buléon, et al., 1998).

The amylose-lipid complexes can be crystalline or amorphous depending on the temperature at which they form. The two forms cannot be differentiated by differential scanning calorimetry (DSC) since they exhibit very similar melting/decomplexing enthalpy and temperature values. The latter (non crystalline) form consists in individual complexes in which single helices are not involved in a crystalline packing. Their X-rays diffraction diagrams were mentioned earlier (section 2.1.1 Chemistry and structure) and the patterns are shown in Figure 2-5. According to Figure 2.5 and Bragg's law, the diffractogram usually can be transformed into Bragg's peak or diffraction profile as shown in Figure 2-24. Regarding the structural study of starch-flavour after hydrothermal treatment, the inclusion complex is one of the most interesting point of study. XRD pattern of flavour-inclusion complex is called Vh-type which deviate from A- or B-type (native forms).

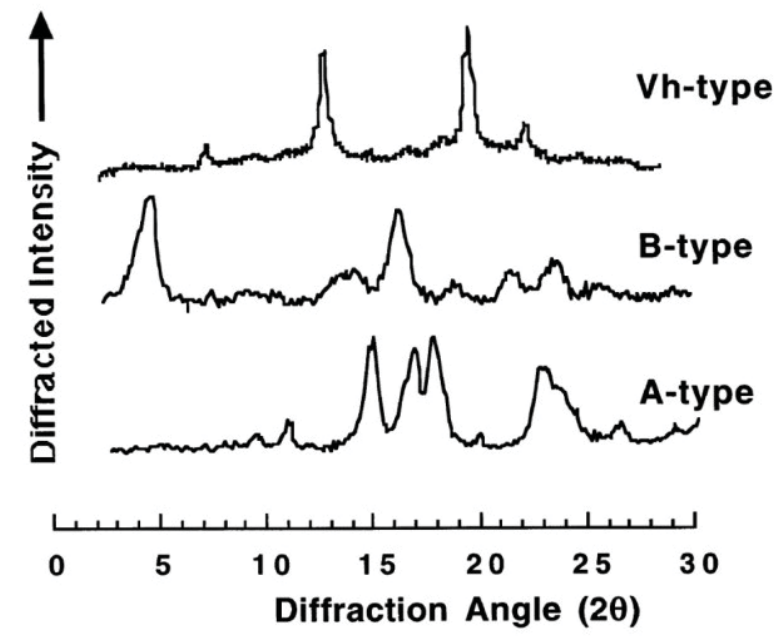

Figure 2-24: X-ray diffraction diagrams of A-, B- and Vh-type starch (Buléon, et al., 1998)

WAXS profile and XRD diffractograms are similar as shown described before whereas the scattering pattern of SAX is different due to angle of study (Figure 2-25). SAXS experiment and data interpretation can provide information about starch lamellar structure 
(Pikus, 2005). Combining WAXS and SAXS may result in the scattering profile of granule as shown in Figure 2-26. This figure gives a perspective view of granule morphology from crystal to lamellar by X-ray techniques.

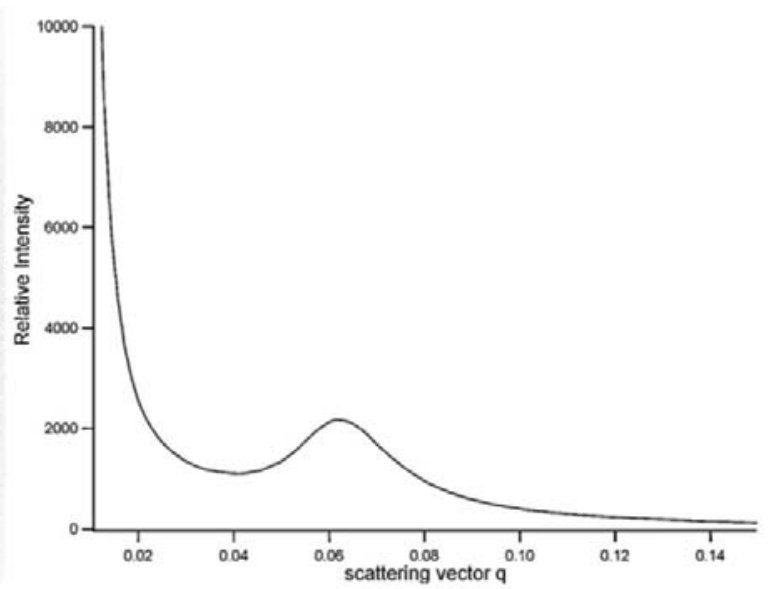

Figure 2-25: Scattering pattern from regular maize starch and corresponding SAXS curve showing relative intensity vs. scattering vector (Blazek \& Gilbert, 2011).

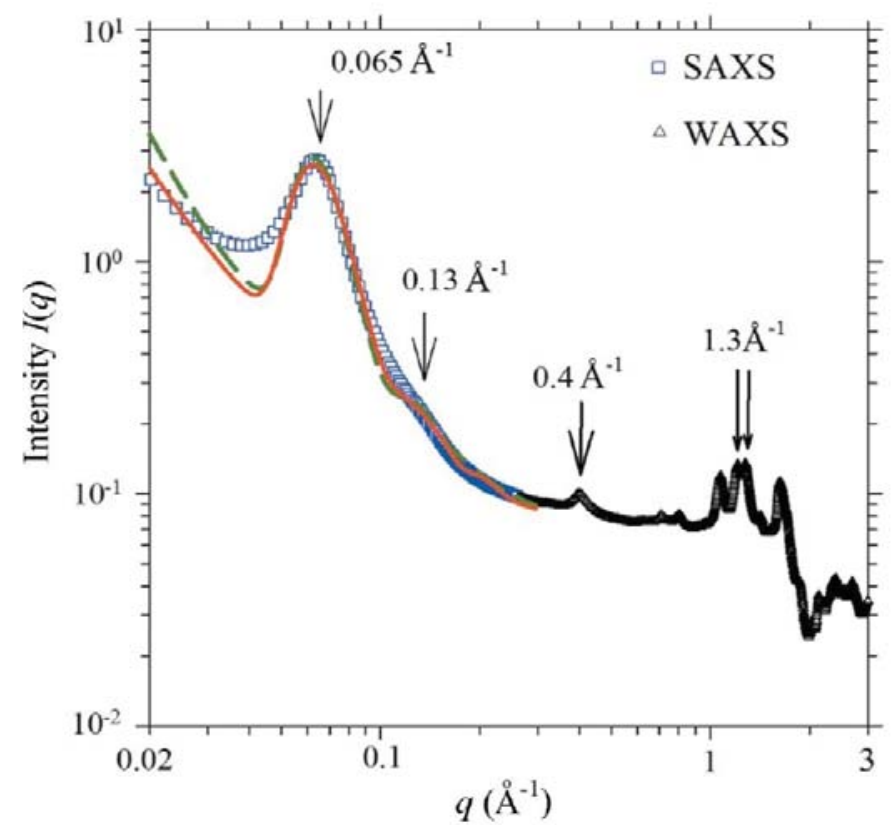

Figure 2-26: Integrated SAXS-WAXS data measured for native tapioca in excess water. The arrows indicate the lamellar peaks at $q=0.065$ and $0.13 \AA^{-1}$, the $(100)_{H}$ reflection at $q=0.40 \AA^{-1}$ of hexagonal (B-type) crystals, and the characteristic twin peaks near $1.3 \AA^{-1}$ of the monoclinic (A-type) crystal. SAXS data are fitted with the model comprising either arrayed elliptic plates (dotted curve) or disk plates (solid curve) (H-K. Huang, et al., 2014). 
Another advantage of SAXS experiment is the sample chamber. It can be equipped with other equipment and allows in situ study (Cameron \& Donald, 1992; H-K. Huang, et al., 2014; Kalapakdee \& Amornsakchai, 2014; Soontaranon \& Rugmai, 2012; Waigh, Gidley, Komanshek, \& Donald, 2000). Waigh et al., (2000) integrated dynamic SAXS/WAXS, DSC and NMR to study phase transformation during starch gelatinisation. They used the liquid crystalline approach to explain the change of starch structure (Waigh, Gidley, et al., 2000). This approach requires three parameters to characterise molecular phase behaviour of amylopectin: the lamellar order $(\Psi)$, the orientational order of amylopectin double helices $(\Phi)$, and the helical ratio of the sample $(h$, the helix/coil ratio, a measure of helix-coil transition of the double helices) (Waigh, Gidley, et al., 2000). All starches (A, B and C type) in the dry state (water content $\leq 5 \% \mathrm{w} / \mathrm{w}$ ) are in glassy nematic state (Rarm et al., 2013). Single DSC endotherm is found in this case and it is up to helix-coil transition (Rarm, et al., 2013). There are 2 processes occurring during starch gelatinisation in excess water (water content $40 \% \mathrm{w} / \mathrm{w}$ ): dissociation of the helices side-by side, helix coil transition (unwinding) which occur simultaneously and rapidly, resulting in single DSC endotherm (Waigh, Gidley, et al., 2000). Two DSC endotherms are usually been observed when the starch is heated under limiting water (water content $>5,<40 \% \mathrm{w} / \mathrm{w}$ ). These biphasic endotherms relates to crystalline smectic-nematic phase transition ( $1^{\text {st }}$ endotherm) and helices unwinding transition $\left(2^{\text {nd }}\right.$ endotherm) (Figure 2-27). This helix-coil transition is broader in A-type starch (wheat) than with B-type (potato) due to the greater length of helices than in B-type (Waigh, Gidley, et al., 2000). Low water content limits granule swelling capacity and crystalline disruption however continuously heating allows crystallites undergo a conventional melting transition, leading to an additional DSC endotherm. Although there is insufficient water the thermal energy is sufficient to break the intermesogen hydrogen bonds to increase the mobility of the amylopectin double helices sideby-side. Therefore, the SAXS peak is not lost through a smectic $(\Phi>0, \Psi>0, \mathrm{~h}>0)$ to nematic/isotropic phase change $(\Phi>0 /=0, \Psi=0, \mathrm{~h}>0$ ) (Figure 2-27). The two DSC endotherms occur due to lamellar order parameter $(\Psi)$ is lost in the crystalline smectic to isotropic/nematic transition at lower temperature, and then the helix-coil transition (h) occurs at higher temperatures (Waigh, Gidley, et al., 2000). 
(i)

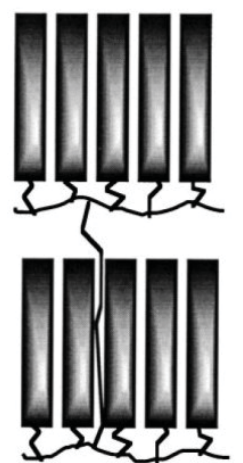

SMECTIC

$(\phi>0, \psi>0, h>0)$

(ii)

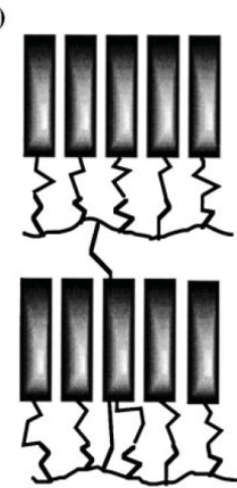

SMECTIC

$(\phi>0, \psi>0, h>0)$

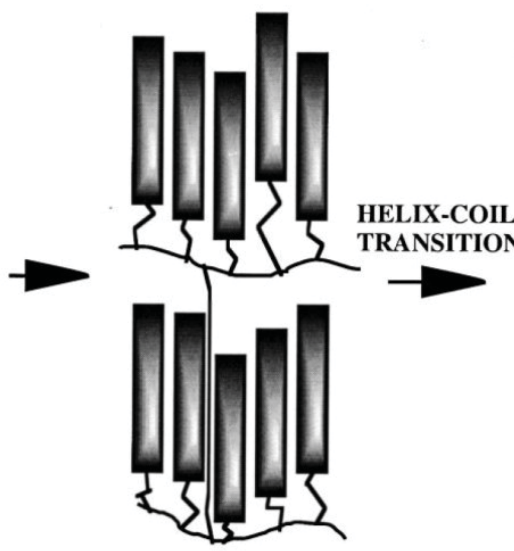

NEMATIC $(\phi>0, \psi=0, \mathrm{~h}>0)$

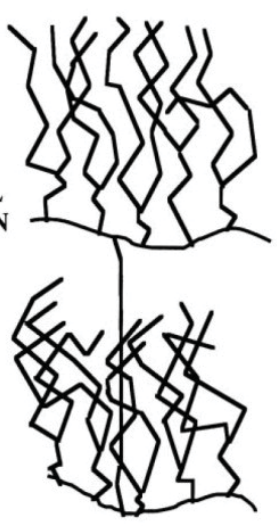

GEL

$(\phi>0, \psi=0, \mathrm{~h}=0)$

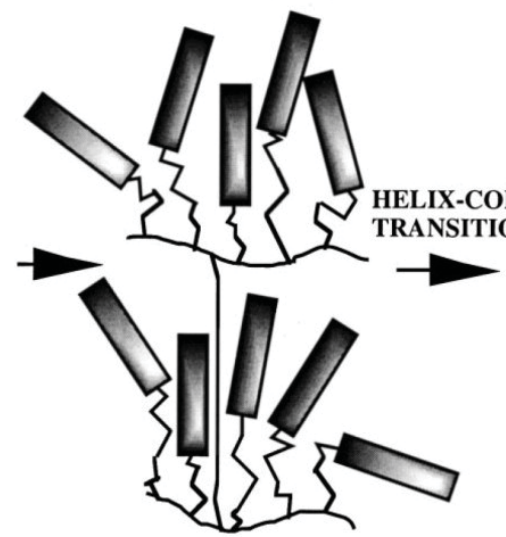

ISOTROPIC

$(\phi=0, \psi=0, h>0)$

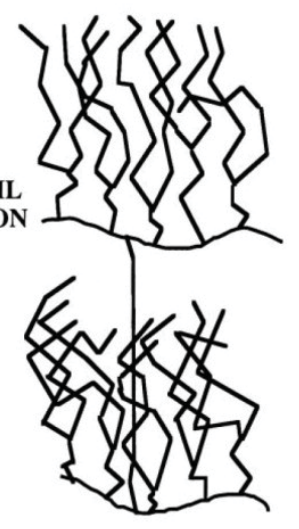

GEL

$(\phi=0, \psi=0, \mathrm{~h}=0)$

Figure 2-27: The two-stage process involved in the gelatinisation of starch in limiting water.

Two different processes are shown for $A$ and $B$ type starches. It is proposed that the intermediate phase is determined by the length of amylopectin helices. Relative values of the orientational (Ф), lamellar $(\Psi)$ and helical order parameter (h) are included. (i) In B-type starch the intermediate phase is nematic in character, (ii) and in A-type starch the intermediate phase is isotropic in character (Waigh, Gidley, et al., 2000).

SAXS experiments are generally performed by having synchrotron radiation as $\mathrm{X}$ ray sources (Cameron \& Donald, 1992; Cameron \& Donald, 1993b; H-K. Huang, et al., 2014; Jenkins \& Donald, 1998; Popov, et al., 2009; Waigh, Gidley, et al., 2000). This is related to the properties of $X$-ray beamline and instrument set up. There are numerous difficulties in light focusing, controlling scattering angle and light alignment when using other X-ray sources rather than synchrotron (Glatter \& Kratky, 1982). The advantages of synchrotron radiation source are: (a) very high intensity, (b) very good intrinsic collimation, (c) the source 
is white, (d) the radiation is emitted in pulses a few tenths of a nanosecond long with a repetition frequency of a megahertz (Glatter \& Kratky, 1982). SAXS beamline, at Synchrotron Light Research Institute (SLRI), Thailand for instance, is capable to analyse the sample on 2 different scattering angles (wide and small) depending on sample-to-detector distance (Rarm, et al., 2013; Soontaranon \& Rugmai, 2012). Scattering vector, $q$, of SAXS and WAXS at this station range from 0.1 to $2 \mathrm{~nm}^{-1}$ and 1.5 to $40 \mathrm{~nm}^{-1}$, respectively (Rarm, et al., 2013; Soontaranon \& Rugmai, 2012).

\section{Fourier Transform Infrared (FTIR) Spectroscopy}

Infrared spectroscopy is one of the most often used spectroscopic tools as it is capable to elucidate the structure, physical properties and interactions of polymers e.g. carbohydrate (Kacurakova \& Wilson, 2001). It has been widely used in structural identification and analysis since it is simple, rapid, non-destructive and without complicated sample pre-treatment before measurement as well as capable to provide useful information on crystallinity of various materials (Q. Sun, et al., 2014). Regarding carbohydrate research, FTIR has been used in structural evaluation (configuration and conformational analysis), systematic fingerprinting of carbohydrate in various states, and monitoring structural changes (equipped with microscope) (Kacurakova \& Wilson, 2001).

The measurement is based on the interaction between infrared light and the matter. Such an interaction results in motion of waves. Certain molecules can react with infrared light and transmit or absorb specific frequency. The absorption wavelengths induce atomic bond to enter excited vibrational states, which can be detected and interpreted by FTIR detector (Beasley, Bartelink, Taylor, \& Miller, 2014). The absorption in infrared spectroscopy means transitions between vibrational energy states and rotational substrates of the molecule. These transitions and absorption of infrared light can occur only if the vibration causes a change in the dipole moment of molecule resulting in FTIR spectra. Each spectrum of the FTIR spectra behaves like chemical fingerprint (Beasley, et al., 2014; Kacurakova \& Wilson, 2001; Wilson, 1990). The obtained spectra can be assigned to specific functional groups which facilitates structural elucidation and quantification (Kacurakova \& Wilson, 2001; Wilson, 1990). Quantitative analysis can be done by applying FT-IR spectroscopy together with chemometric methods since the intensity of the absorption is proportional to the concentration of the absorbing species (Capron, Robert, Colonna, 
Brogly, \& Planchot, 2007; Kacurakova \& Wilson, 2001). The emission and absorption spectra are collected and computerised with mathematic algorithm (Fourier transform). Generally, the acquisition of FTIR spectroscopy can be done in 3 methods: attenuated total reflectance (ATR), transmission-based, and diffuse reflectance (Wilson \& Tapp, 1999). They are different in term of sample preparation and wavelength collection. Sample can be directly measured by ATR method while the other 2 require mixing with $\mathrm{KBr}$. Although $\mathrm{KBr}$ is used in both transmission and DRIFT modes but pelleting is required in transmission mode (Beasley, et al., 2014). FTIR spectroscopy for carbohydrate researches relies on mid-infrared spectroscopy which measures the absorption of radiation in the 4000 to $400 \mathrm{~cm}^{-1}$ (wavelength 205-25 $\mu \mathrm{m}$ ) frequency range (Kacurakova \& Wilson, 2001; Wilson, 1990).

FTIR spectroscopy has been employed in various carbohydrate researches ranging from monosaccharide to polysaccharide. Concerning particularly FTIR research in starch, the researchers were done on starch granule, gelatinisation, inclusion formation, structural alteration, phase transition, retrogradation etc (Biais, et al., 2006; Flores-Morales, Jiménez-Estrada, \& Mora-Escobedo, 2012; Kacurakova \& Wilson, 2001; Pozo-Bayon, Guichard, \& Cayot, 2006; Q. Sun, et al., 2014). Starch structure can be compared as in Figure 2-28: the absorbance in the region of $1300-800 \mathrm{~cm}^{-1}$ corresponds to vibration associated with $\mathrm{C}-\mathrm{C}, \mathrm{C}-\mathrm{O}$ and $\mathrm{C}-\mathrm{H}$ stretching and $\mathrm{C}-\mathrm{OH}$ bending mode in starch polymer conformation (Capron, et al., 2007; Y. Sun et al., 2014). ATR-FTIR was applied to study the organisation of external region of starch granules from different botanical origins (Sevenou, Hill, Farhat, \& Mitchell, 2002). The measurement was able to distinguish the organisation of the edge of the starch granule but unable to differentiate between A- and B- types starch (Sevenou, et al., 2002). The crystallinity of starch can be measured by FTIR spectroscopy since the absorbance between $1300-800 \mathrm{~cm}^{-1}$ derives from amorphous and crystalline region of starch (Smits, Ruhnau, Vliegenthart, \& van Soest, 1998; Y. Sun, et al., 2014). Determination of starch crystallinity by this technique requires the suitable probe band and reference to use as standard of measurement. Therefore, the obtained results of crystallinity study by FTIR and XRD are no significantly different (Y. Sun, et al., 2014).

Diffuse reflectance Fourier transform infrared (DRIFT) is compatible for retrogradation and physical ageing of starch. The peaks at 1047, 1022 and $995 \mathrm{~cm}^{-1}$ relate to crystalline, amorphous and water inside the starch, respectively (Capron, et al., 2007; Smits, et al., 1998). However, Smits et al., (1998) stored freeze-dried starches (after gelatinisation) 
above their $\mathrm{T}_{\mathrm{g}}$, at $90 \% \mathrm{RH}$ for 32 days. They found that the amorphous peak $\left(1022 \mathrm{~cm}^{-1}\right)$ reduced upon storage (Smits, et al., 1998). The study of variation of $1000 / 1022 \mathrm{~cm}^{-1}$ ratio is a promising approach to understand phase transition due to hydration in starch because the bands intensities in this range can explain the mobility related to the glass transition (Capron, et al., 2007). The increasing 1000/1022 $\mathrm{cm}^{-1}$ ratio relates (Capron, et al., 2007) to the increasing order of double helices (Capron, et al., 2007). The study of starch in rubbery and glassy starch by Attenuated Total Reflectance-FTIR (ATR-FTIR) is in accordance with the model of liquid crystal structure and mesophase variation that water allows the selfassembly of amylopectin helices leading to layered organised structure (Capron, et al., 2007).

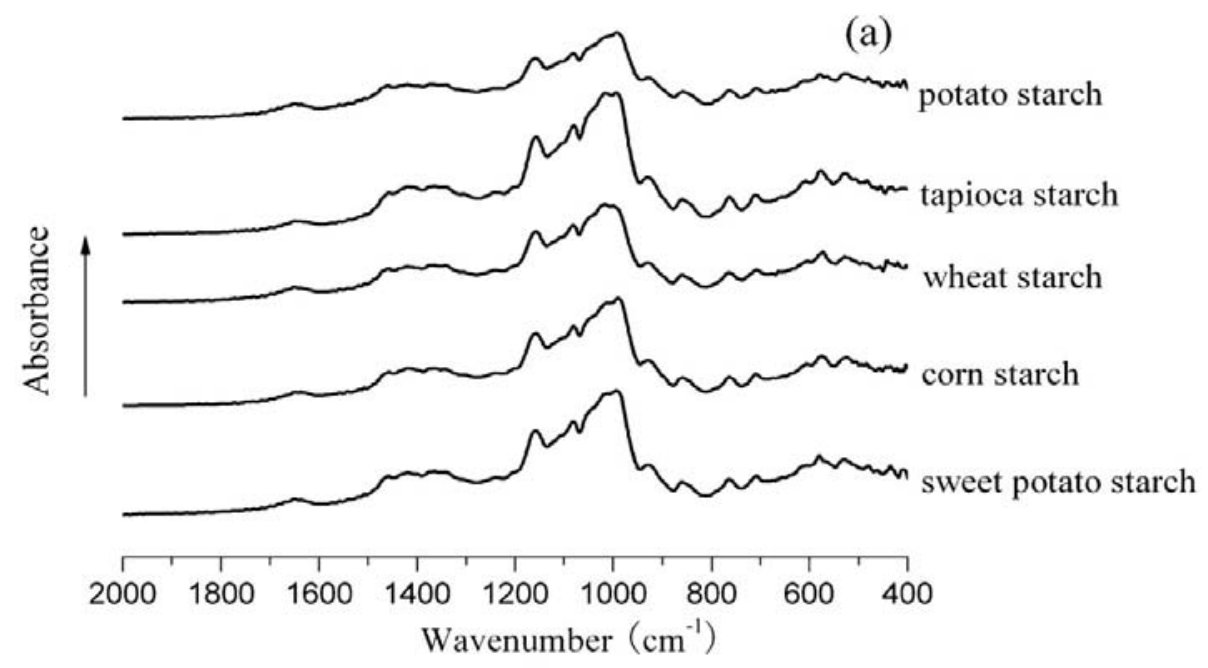

Figure 2-28: Infrared spectra of starch from various botanical origins (Y. Sun, et al., 2014)

The specificity of infrared spectroscopy to certain chemical bonds and functional group (e.g. $1706 \mathrm{~cm}^{-1}$ ) of carbonyl absorption in hexanoic acid facilitates the quantification of starch-inclusion complex formation (Biais, et al., 2006; Fanta, et al., 1999; Lay Ma, et al., 2011). The studies of complex formations are usually done in transmission mode. With this mode, samples generally undergo interaction with interested compounds, washed and mixed with $\mathrm{KBr}$ then die cast prior analysis. $\mathrm{KBr}$ helps to reduce opacity of the sample or reacts as diluent. Biais et al., (2006) studied the complexes between aroma compounds and amylose. Their samples were washed by the mixture of water and ethanol. The researchers successfully quantify of amylose-aroma complex by using FTIR spectroscopy together with chemometric by mean principle component analysis (Biais, et al., 2006). According to Figure 
$2-29$, it can be seen clearly that the spectra are the different at $1600-1800 \mathrm{~cm}^{-1}$, these was according to complex formation ( $3 a$ non-complex formation, 3b-d complex formation) (Biais, et al., 2006).

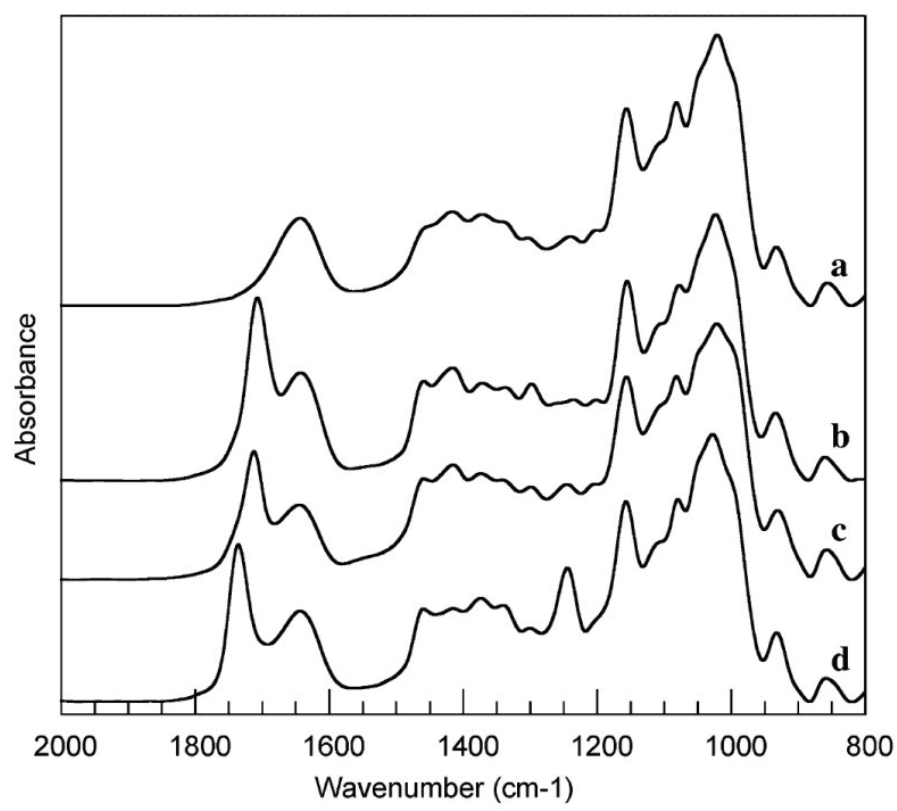

Figure 2-29: FT-IR spectra of amylose (a), complexed with decanoic acid (b), with hexanoic acid (c) and with 1,5-decanolactone (d) (Biais, et al., 2006).

In order to sum up, Figure 2-30 might be the best to perspective of starch structural features, analytical technique, research finding and starch model. 


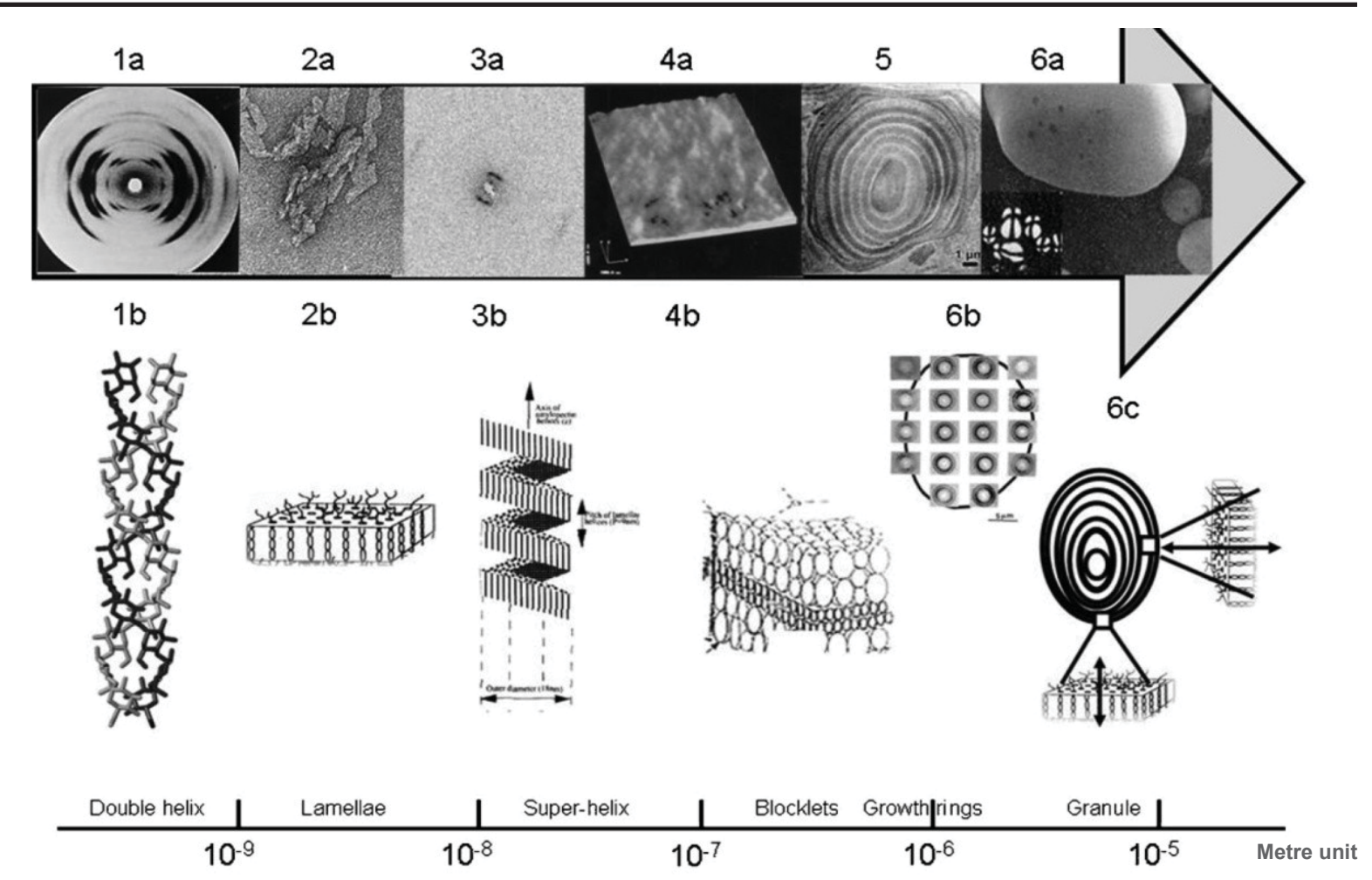

Figure 2-30: The different level of structural organisation (Pérez \& Bertoft, 2010)

From left to right: 1 , glucose unit; 1 , double helix; 2, lamella; 3, super helix; 4, blocklets; 5, growth rings; 6 , granule.

(1a) X-ray fibre diffraction pattern demonstrating a double helix structure

(1b) Model of the double helix structure

(2a) Transmission electron microscopy image on hydrolysed starch, showing the shape of the crystalline lamellae

(2b) Model of a crystalline lamella made of about 100 double helices.

(3a) SAXS and WAXS diffraction images indicating the occurrence of a super-helix structure.

(3b) The super-helix model, with a pitch of $9 \mathrm{~nm}$ and a diameter of $18 \mathrm{~nm}$.

(4a) Image by atomic force microscopy of a typical surface of a starch granule. The bumps seen on the surface show the presence of blocklets.

(4b) Blocklet model. The blocklet size is supposed to be smaller in the amorphous regions than in the semicrystalline regions. Transmission electron microscopy image of an ultrathin section of hydrolysed starch granule showing the growth rings as alternate layers of amorphous and semi-crystalline regions

(6a) Starch granule observed SEM and the corresponding granule under polarized light.

(6b) Set of microfocus X-ray diffraction patterns recorded on a starch granule showing the distribution and orientation of the crystalline domains in a starch granule. Each diffraction pattern corresponds to an area of about $3 \mathrm{~mm} 2$ of the specimen and steps of $7 \mathrm{~mm}$ separate two patterns

(6c) Starch granule section showing the radial orientation of the crystalline domains (lamellae) in a starch granule. 


\subsection{Structural evolution}

Prior to hydration and heating, the amorphous regions of semi crystalline starch are vitreous (glassy, hard, and brittle). Increasing both hydration and temperature will cause the glass transition of the amorphous regions into the less viscous, "rubbery" state (Roos, 1995) Figure 2-31. Heating increases molecular mobility and resulted in crystalline melting. Starch paste could become rigid (gel) following a slow cooling while dehydration coupled with rapid cooling results in amorphous starch (Biliaderis, 2009; Roos, 2007; Roudaut, et al., 2004).

Generally, physical evolution may occur as a result of structural changes versus time towards either an equilibrium state or closer to equilibrium following and/or following a change of storage conditions (humidity or/and temperature) (Jiranuntakul, et al., 2013).

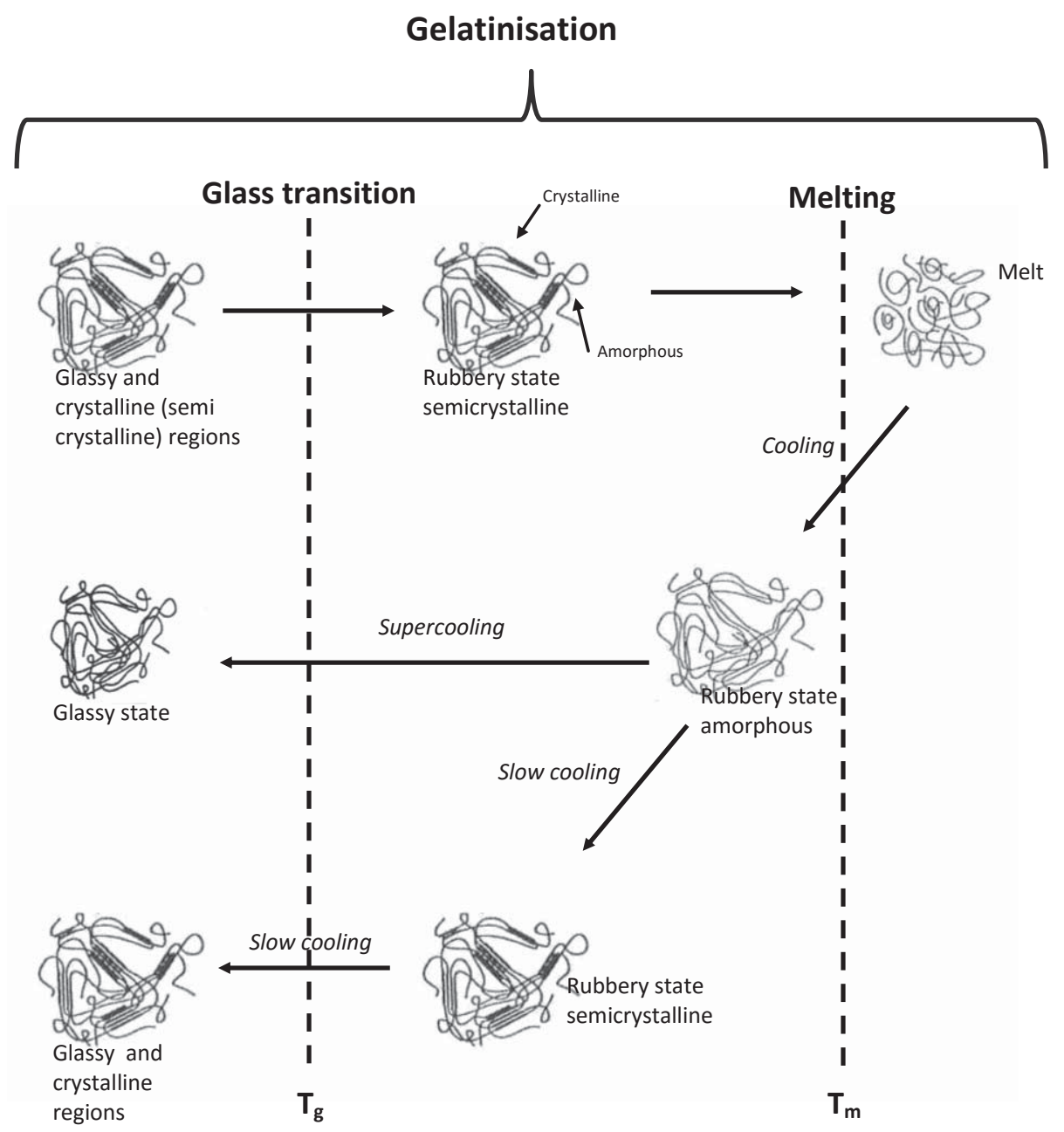

Figure 2-31: Mechanism of starch phase transition versus temperature (Buléon, 1990). 


\subsubsection{Glass transition: a key parameter}

Thermal treatment above melting temperature, such as for baking, leads to a loss of crystalline structure for the considered material which above $T_{m}$ becomes liquid. Depending on the cooling kinetics, the structuration will be different. It will evolve towards crystalline state i.e. thermodynamic equilibrium at slow cooling rate, whereas if the cooling rate is too rapid to enable this long distance reorganization, the material will evolve from liquid to highly viscous supercooled liquid/rubber. If the cooling carries on below the glass transition temperature $\left(\mathrm{T}_{\mathrm{g}}\right.$ ) (generally $100{ }^{\circ} \mathrm{C}$ below the melting temperature of the corresponding crystalline material), the amorphous material vitrifies into a disordered solid glass (Roos, 2010; Roudaut, et al., 2004).

The glass transition is the reversible amorphous solid to liquid transformation (Roos, 2010). Glassy materials behave like brittle solids, but without crystalline structure and only short range order (Carter \& Schmidt, 2012; Roos, 2010). It is classified as a second order phase change, i.e. accompanied by thermodynamic (enthalpy, specific volume, entropy) and mechanical changes (viscosity, rigidity, dielectric) (Carter \& Schmidt, 2012; Champion, Le Meste, \& Simatos, 2000). This transition corresponds to the disappearance or appearance (depending on the direction of the thermal treatment) of cooperative motions involving several tens of carbon atoms generally associated with the main relaxation or $\alpha$ relaxation.

Glass transition temperature $\left(T_{g}\right)$ is an important key for process operation (Bhandari \& Howes, 1999). The glass transition temperature is a particularly important determinant characteristic of dehydration and stability of carbohydrate containing food (Roos, 2007). Indeed glassy foods are often considered as stable and the glassy state is of great importance for textural characteristics of low moisture foods such as potato chips, cookies, powders and extruded snacks (Roos, 1995). Foods in glassy state are in a metastable condition due to low molecular motion and remain stable for extended periods of time (months to years) (Bhandari \& Howes, 1999; Biliaderis, 2009). Several quality attributes relate to the physical state of the ingredients in the dry product. Flavours, vitamins, enzymes and microorganisms are minor components present within the food matrix. Any changes in the physical state of the product have the possibility to affect the physicochemical characteristics of the different ingredients of the product (Bhandari \& Howes, 1999). 
As a consequence the glass transition temperature has become an important criterion for the control of amorphous quality and requires to be controlled for an optimised quality upon storage. The glass properties depend on how the glass was formed or immobilised. It may contain a large (following a very fast cooling) or low (after a moderate cooling rate) "free volume" content, depending how the structure was frozen (Roos, 2007). Rapid cooling enhances the possibility of evolution below $\mathrm{T}_{\mathrm{g}}$ by increasing structural disorder and thermodynamic instability (Borde, Bizot, Vigier, \& Buléon, 2002). Tg is also sensitive to the system's composition: it increases with increasing molecular weight, decreasing branching degree, decreasing plasticizer content and increasing degree of crystallinity for semi crystalline polymers.

Few papers present the effect of the degree of crystallinity on the $T_{g}$ of semi crystalline starch. Native starch has been shown to exhibit higher $\mathrm{T}_{\mathrm{g}}$ than its pre-gelatinised equivalent through a lower mobility of the crystallite-amorphous interfaces (Zeleznak \& Hoseney, 1987) as shown in Figure 2-32.

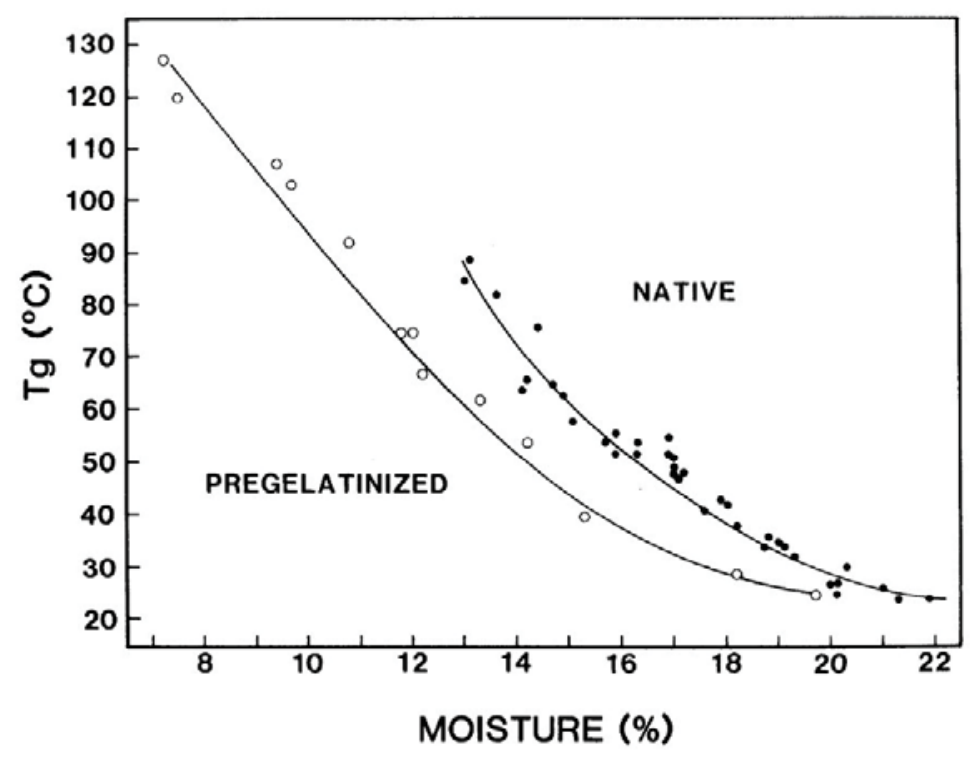

Figure 2-32: Plot of the variation of the glass transition temperature $\left(T_{g}\right)$ versus moisture content in native and pregelatinised wheat starch (Zeleznak \& Hoseney, 1987).

The effect of plasticiser content is important through the effect of product composition but also quite importantly for storage, since Tg will be affected by humidity changes. Figure 2-32 shows the progressive increase in the glass transition temperature with 
decreasing moisture content, giving a typical $T_{\mathrm{g}}$ versus moisture curves. At moisture levels greater than $22 \%, T_{g}$ is observed below room temperature. The $T_{g}$ curves of native and pregelatinised wheat starch appear to become asymptotic at room temperature. The difference in $T_{g}$ reflects the relative difference in degree of crystallinity between two types of starches. The pregelatinised starch is non-crystalline, whereas native wheat starch is 15 to $35 \%$ crystalline (Figure $2-32$ ).

The evolution of an amorphous material depends on storage temperature (above $\mathrm{Tg}$ or below $\mathrm{Tg})$.

\subsubsection{Evolution above the glass transition temperature}

Below melting temperature (Madene, Jacquot, Scher, \& Desobry), the material is a non-equilibrium supercooled state. Therefore various properties of amorphous materials depend on temperature and time. Because of the metastability of the amorphous state such materials tends to crystallise when sufficient time is allowed at temperature above $T_{\mathrm{g}}$. Long range cooperative motions become possible above $T_{g}$, the viscosity decreases above the isoviscosity value defined for $\mathrm{T}_{\mathrm{g}}\left(10^{12} \mathrm{~Pa} . \mathrm{s}\right)$ they enable structural reorganisation causing the recrystallisation of the initially amorphous material. In soft baked products, such reorganisation, is referred as retrogradation for starch, which returns through this to a semi crystalline state similar to its original native one (Waduge, et al., 2006). This evolution which contributes to a large part of bread staling has been thoroughly studied in the literature on baked products with a view to understanding and thus controlling the hardening of originally soft baked products.

The relationship between crystallisation rate and water content or temperature exhibits a bell-shaped behaviour. As an example; isothermal retrogradation kinetics go through a maximum as a function of water content, this maximum is shifted toward higher water content with decreasing temperature (Waduge, et al., 2006). When presented as a function of temperature, the comparable bell shape pattern is described with a maximum comprised between $\mathrm{Tm}$ at the high end and $\mathrm{Tg}$ at the low end. Indeed no crystallisation occurs below $\mathrm{Tg}$. 


\subsubsection{Evolution below $\mathrm{Tg}$}

Many amorphous, food or non-food, materials (freeze dried, spray-dried) are stored in the glassy state. When the glass is stored at sub- $T_{\mathrm{g}}$ temperature, translational motion become constrained; only side group motions (small-scale rotational motions) persist and still allow subsidiary transitions (known as $\beta$ and $\gamma$ relaxations) (Biliaderis, 2009). Provided the molecular mobility is sufficient, structural relaxation tends to occur as a result of enthalpy, specific volume, and entropy decrease towards their equilibrium values (Roudaut, et al., 2004) without ever reaching the crystalline conformation (Morris, Taylor, Farhat, \& MacNaughtan, 2011) (Figure 2-33). The ability to evolve towards a lower energy level is facilitated by storage at temperature close to $T_{\mathrm{g}}$. Structural changes occurring in the glassy state over storage time are referred as physical ageing (Roos, 2007; Roudaut, et al., 2004) or structural relaxation (Morris, et al., 2011). The kinetics of physical ageing depends on: the molecular mobility of glassy state (e.g. storage temperature, $T_{g}$ ); degree of metastability of initial state (e.g. cooling rate); and lesser extent (chemical structure and degree of advancement of structural relaxation (Borde, Bizot, Vigier, \& Buléon, 2002).

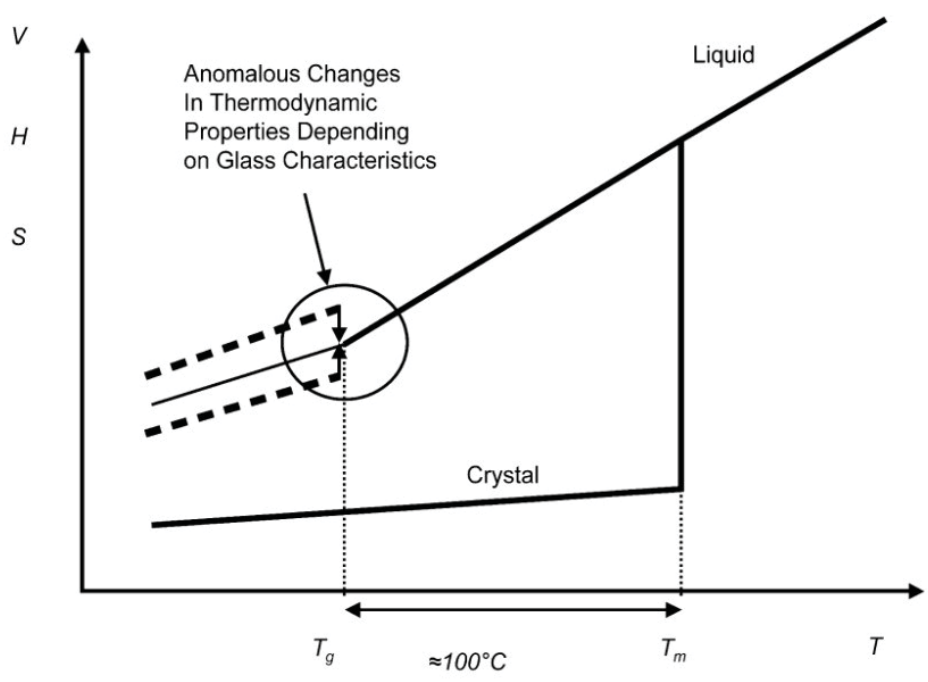

Figure 2-33: Evolution of thermodynamic properties (free volume, enthalpy and entropy) versus temperature (Roos, 2007).

There are several techniques to determine the glass transition temperature and characterise physical ageing depending on the considered parameter. The most common technique is the calorimetric analysis such as Differential Scanning Calorimetry (DSC) since it directly measures the enthalpy flow (Borde, Bizot, Vigier, \& Buleon, 2002; Borde, Bizot, 
Vigier, \& Buléon, 2002) and the change in heat capacity characteristic of the transition appears as sigmoid curve on the thermogram in the endothermic direction. Once relaxation enthalpy occurs upon storage, it causes enthalpy loss and an endothermic overshoot, due to rapid enthalpy recovery upon heating, can be observed on DSC thermogram following a storage below $T_{g}$ (e.g. at room temperature for low moisture systems) (Figure 2-34) (Borde, Bizot, Vigier, \& Buléon, 2002a; Champion, et al., 2000; Morris, et al., 2011).

This endothermic event is suggested to be a consequence of the structural relaxation of the amorphous system (Borde, et al., 2002a). However, an exothermic event can be seen as well when a rapid cooling is followed by a much slower rewarming (Champion, et al., 2000). The endothermic overshoot can also be used to detect the glass transition, with materials for which the heat capacity jump is particularly small and smeared out over a board temperature range (Champion, et al., 2000).

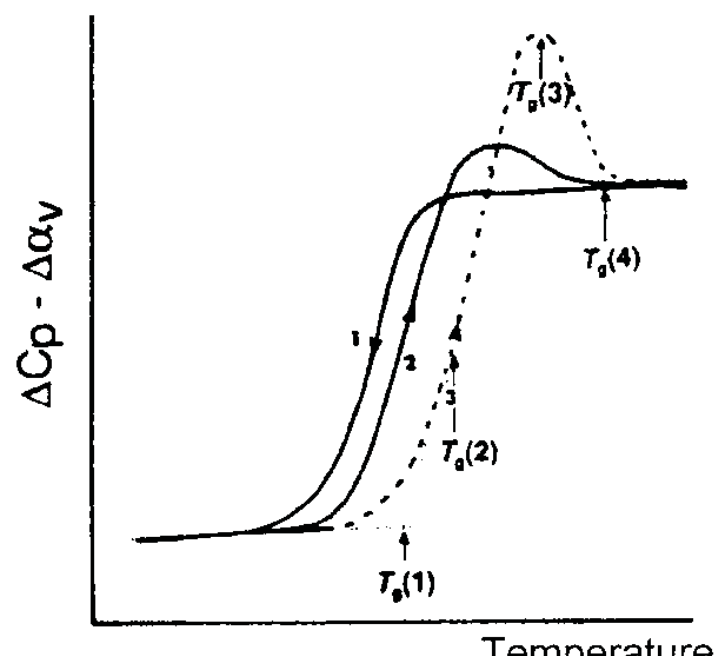

Figure 2-34: Change in physical properties at the glass-liquid transition (Champion, et al., 2000)

Due to various changes occurring upon storage, other parameters than enthalpy relaxation can be cited in order to explain structural changes. Lourdin et al. (2002), showed structural relaxation during ageing of starchy materials by using combination of parameters and techniques based on the measurement of heat capacity, volume, rigidity and conductivity. During ageing, structural relaxation (temperature and time dependent) may result in the stiffening of the materials as a result and decay in conductivity (Glatter \& 
Kratky, 1982). Ageing associates with decreased of diffusivity and increased rigidity as a result of density (Roudaut, et al., 2004). Physical ageing is facilitated in glasses with increasing moisture content, indeed $\mathrm{T}_{\mathrm{g}}$ decreases, then storage temperature becomes closer to $T_{g}$, which facilitates the molecular motions and thus the structural relaxation (Roudaut, et al., 2004).

Structural relaxation and stability of the food tend to be more complex due to it is made from several components. During storage, recrystallisation, phase separation, component migration or interactions between ingredients might occur (Borde, Bizot, Vigier, \& Buléon, 2002). Therefore, understanding glass transition temperature and relaxation as a single component may not be enough to explain or predict food stability. Starch-sucrose extruded for instance, are shown to exhibit different water sensitivities, depending on the sucrose level (0-20\%) (Poirier-Brulez, Roudaut, Champion, Tanguy, \& Simatos, 2006). The enthalpy relaxations in ternary samples were found to be smaller than in native starch alone which is due to lower mobility (Poirier-Brulez, et al., 2006). Borde et al., (2002) report that hydrated polysaccharides are found to age slightly faster than standard synthetic polymer (PMMA - poly methyl methacrylate, PVA - poly vinyl pyrrolidone) which is probably due to different in structural extend and molecular mobility (Borde, Bizot, Vigier, \& Buléon, 2002).

Encapsulation is an interesting technique in food technology designed to protect active compounds or ingredients. The encapsulation consists in reducing molecular mobility to limit active ingredients loss. Several studies were performed in order to determine the favourable conditions (Zasypkin \& Porzio, 2004). Several techniques are employed for retention of flavour during drying, freeze-drying, extrusion, or storage of dry products (Le Meste, et al., 2002). Under appropriate conditions, flavour compounds can be retained to a much larger extent than expected from their volatile character (Le Meste, et al., 2002). The diffusion coefficient for organic compounds drops rapidly, even more rapidly than that for water at low water content. This selective diffusion process, with some modifications is generally accepted as the main process explaining the retention of aroma being entrapped in glassy materials (carbohydrate or proteins) (Le Meste, et al., 2002).

Volatile release/loss from encapsulated carbohydrate matrices is controlled by crystallisation and through the increase of mobility (Le Meste, et al., 2002). Flavour compounds in amorphous matrices are retained at temperatures below $T_{g}$, the retained flavour compounds may be released at temperature above $T_{g}$, due to the crystallisation of 
the amorphous matrix (Busso Casati, et al., 2007) or simply due to the increased molecular mobility. Water and temperature change materials from glassy to rubbery state and promote release of volatiles (Le Meste, et al., 2002). It is found that flavour release from encapsulated spray-dried maltodextrins could be associated with structural collapse. The volatiles may release during rehumidification of freeze-dried foods which can be interpreted by a diffusion-based mechanism where the web thickness within the sample increases with time due to structure collapse (Le Meste, et al., 2002). In case of extruded carbohydrate matrices, the flavour release (at low water content) can be due to diffusion through matrix cracking (Le Meste, et al., 2002). 
Objectives and rationale 


\section{Objectives}

- To explain contribution and role of water in starch matrices during thermal process

- To characterise starch and flavour interactions versus physical state of starch

- To understand the structuration and water content effects on flavour retention and release from starch matrices

\section{Rationale}

It is well understood that native starch interacts with flavour compound via binding interaction whereas the hydrothermally treated starch possibly interacts with the flavour via a special type of binding i.e "inclusion complex" can occur upon gelatinisation. Very little is known about the behaviour and interaction of partially gelatinised starch. Therefore, two flavours compounds with different ability to interact with starch: ethyl hexanoate (complexing compound) and 2-hexanone (non complexing compound) are chosen for a comparative study.

This study aims at understanding interactions between starch and flavour upon hydrothermal treatment at intermediate hydration and temperature. Based on the effect of water on the gelatinisation temperature, both water content and heating temperature are varied in order to obtain samples at different gelatinisation degrees. Hence, the investigation of structural alteration upon hydrothermal treatments is required. It is also interesting to further understand the stability of the resulting starches with different degree of crystallinity and flavour content. The hydrothermally treated starches are subjected to freeze-drying in order to preserve their structures. This way, the structuration expectedly achieved by the thermal treatment should not be affected by retrogradation. The freezedried starches are in the glassy state, and then the stability study is intended to measure their abilities to relax during storage at different relative humidities. The different properties of the chosen flavours lead to investigation on retention and release quantities. Based on the literature review, there is no report on the influence of ethyl hexanoate and 2hexanone on starch pasting properties. The understanding of flavour addition effect on pasting properties is important since the pasting properties control many applications of starch. 
Chapter3: Materials and methods 


\section{Thesis approach and workflow}

The thesis approach was designed according to the objectives. Based on the literature study, the samples were prepared at various starch and water ratios to obtain different properties (\% residual of native starch). Freeze-drying was employed to preserve the properties of samples after their preparation and prior to further study.

Multiscale structure analyses were performed to characterise structuration of flavourstarch systems Thesis approach is simplified as a schematic of workflow as shown below. The detail of each study is later explained.

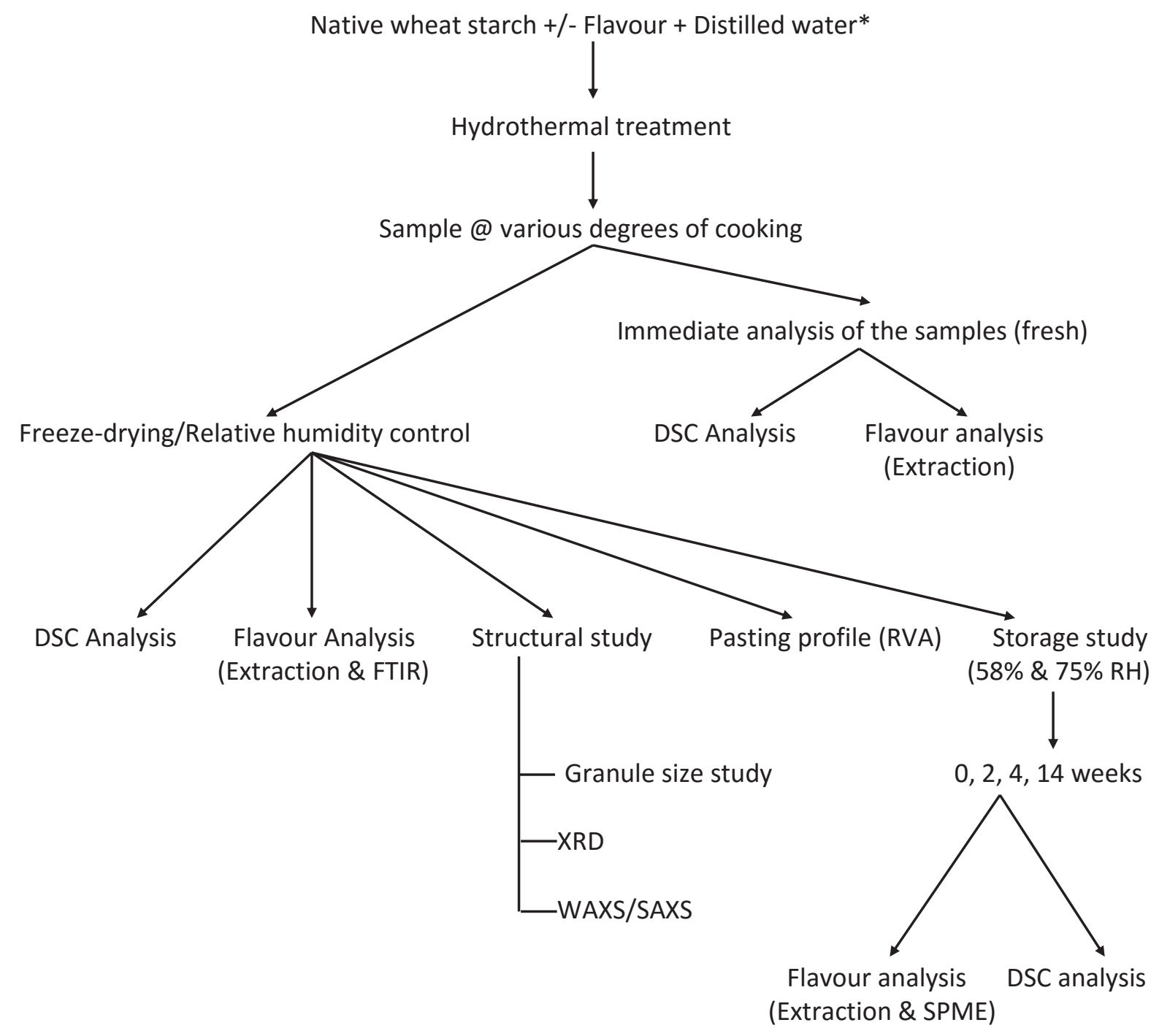

*Recipe A: 20/80, C: 50/50 gram of starch/water

Figure 3-1: Schematic of sample preparation and analysis 


\subsection{Materials}

Native wheat starch as well as pregelatinised starch (Pregeflo ${ }^{\circledR} \mathrm{W}-\mathrm{HV}$ ) were kindly provided by Roquette Frères (Lestrem, France). Ethyl hexanoate and 2-hexanone were obtained respectively from Sigma-Aldrich (Steineheim, Germany) and Acros (Geel, Belgium). Their main physical properties are presented in Table 3-1. Methyl heptanoate and ethyl octanoate produced by Sigma-Aldrich (Steineheim, Germany) were used as internal standards of flavour extraction and gas chromatography injection, respectively. Sodium chloride was obtained from Sigma-Aldrich (Steinheim, Germany).

Table 3-1: Physicochemical properties of flavour compounds

\begin{tabular}{|c|c|c|c|c|c|c|c|}
\hline Flavour & $\begin{array}{c}\text { Purity } \\
(\%)\end{array}$ & Density & $\begin{array}{c}\mathrm{MW} \\
(\mathrm{g} / \mathrm{mol})\end{array}$ & $\begin{array}{c}\text { Solubility* } \\
\text { (g/l) }\end{array}$ & $\begin{array}{c}\text { Hydrophobicity } \\
\text { Log } P_{\text {(oct-water) }}\end{array}$ & $\mathrm{K}_{\text {water }}{ }^{* *}$ & $\begin{array}{c}\text { Odour } \\
\text { Descriptor }\end{array}$ \\
\hline $\begin{array}{l}\text { Ethyl hexanoate } \\
\mathrm{C}_{8} \mathrm{H}_{16} \mathrm{O}_{2}\end{array}$ & 99 & $0.873^{\mathrm{a}}$ & 100.1 & $0.65^{b}$ & $2.83^{\mathrm{c}}$ & $3.3 \times 10^{-2 e}$ & $\begin{array}{l}\text { Fruity, banana, } \\
\text { pineapple }^{\mathrm{g}}\end{array}$ \\
\hline 2-Hexanone & 99 & $0.811^{\mathrm{a}}$ & 144.2 & $16.2^{\mathrm{b}}$ & $1.38^{\mathrm{d}}$ & $5.2 \times 10^{-3 f}$ & Sweet, candy \\
\hline \multicolumn{8}{|l|}{$\mathrm{C}_{6} \mathrm{H}_{12} \mathrm{O}$} \\
\hline \multicolumn{8}{|c|}{ *Solubility in water at $25^{\circ} \mathrm{C}$} \\
\hline \multicolumn{8}{|c|}{ **Partition coefficient in pure water } \\
\hline \multicolumn{8}{|c|}{ a: Windholz, Budavari, Blumetti \& Otterbein (1983) } \\
\hline \multicolumn{8}{|c|}{ b: Marco Covarrubias-Cervantes, Sébastien Bongard, Dominique Champion, \& Andrée Voilley (2005a) } \\
\hline \multicolumn{8}{|c|}{ c: Martuscelli, Savary, Pittia, \& Cayot (2008) } \\
\hline \multicolumn{8}{|c|}{ d:Jouquand et al. (2004) } \\
\hline \multicolumn{8}{|c|}{ e: Lubbers \& Butler, (2010) } \\
\hline \multicolumn{8}{|c|}{ f: Extrapolate from Jouquand et al. (2004) } \\
\hline g: Seuvr & Rochard, & \& Voilley & 2006) & & & & \\
\hline
\end{tabular}

\subsection{Sample preparation}

\subsubsection{Fresh samples}

The samples were prepared with a single flavour in order to compare the effect of flavour addition against no flavour addition separately. Two formulae according to weight ratios between native wheat starch and water were chosen: 20/80 (recipe A) and 50/50 (recipe C) g of starch per g of water to study the influence of water content. The native 
starch contained $11 \%$ of moisture content prior its mixing with water. The flavours were added directly onto starch prior to addition of water. The added quantity of ethyl hexanoate was $0.17 \mathrm{~g} / 100 \mathrm{~g}$ of starch-water mixture while the experiment with 2-hexanone were done with 0.16 and $1.6 \mathrm{~g} / 100 \mathrm{~g}$ of starch-water mixture. The next steps were done in the same manner for samples with/without flavour. Samples were mixed in closed container and left standing on magnetic stirrer (Variomag Multipoint, Thermo Scientific) at $800 \mathrm{rpm}$ for one hour prior thermal treatment. The mixtures of starch and water were heat treated in an open reactor (Eurostar Laborreaktor, IKA) with manual agitation at 65 , and $85{ }^{\circ} \mathrm{C}$ for $10 \mathrm{~min}$. The reactor was equipped with a temperature controlled bath (Proline P5, Lauda). Following their thermal treatment, the heat-treated starch samples were kept in closed plastic containers throughout the study. Once the samples cooled down to room temperature, they were subjected to Differential Scanning Calorimetry (DSC) and moisture content analysis. The samples name derived from their formulae and treatment temperature, therefore they were denoted as A65, A85, C65 and C85 (Table 3-2). Regarding the samples with flavour addition, the added ethyl hexanoate contents per gram of starch at dry basis were $0.0096 \mathrm{~g}$ in A65 and A85 while in C65 and C85 was $0.0038 \mathrm{~g}$. In case of 2-hexanone, the added contents were $0.0089 \mathrm{~g}$ in A65 and A85 and $0.0036 \mathrm{~g}$ in $\mathrm{C} 65$ and C85.

Table 3-2: Samples description

\begin{tabular}{|c|c|c|c|c|c|}
\hline \multirow[t]{2}{*}{ Recipe } & \multirow{2}{*}{$\begin{array}{l}\text { Ratio Starch-Water } \\
\text { (g/g wet weight) }\end{array}$} & \multirow{2}{*}{$\begin{array}{c}\text { Added } \\
\text { flavour }(\mathrm{g})^{*}\end{array}$} & \multirow{2}{*}{$\begin{array}{c}\text { Flavour content } \\
\text { (g/g of dry starch)** }\end{array}$} & \multicolumn{2}{|c|}{ Sample Name } \\
\hline & & & & $65^{\circ} \mathrm{C}$ & $85^{\circ} \mathrm{C}$ \\
\hline$A$ & $20 / 80$ & - & - & A65 & A85 \\
\hline C & $50 / 50$ & - & - & C65 & C85 \\
\hline A+Ethyl hexanoate & $20 / 80$ & 0.17 & 0.0096 & A65EH & A85EH \\
\hline$C+$ Ethyl hexanoate & $50 / 50$ & 0.17 & 0.0038 & C65EH & $\mathrm{C} 85 \mathrm{EH}$ \\
\hline $\mathrm{A}+2-$ Hexanone $\mathrm{C1}^{\mathrm{C}}$ & $20 / 80$ & 0.16 & 0.0089 & $\mathrm{~A} 65 \mathrm{H}^{\mathrm{C1}}$ & $\mathrm{A} 85 \mathrm{H}^{\mathrm{C1}}$ \\
\hline $\mathrm{C}+2-$ Hexanone ${ }^{\mathrm{C} 1}$ & $50 / 50$ & 0.16 & 0.0036 & $\mathrm{C} 65 \mathrm{H}^{\mathrm{C} 1}$ & $\mathrm{C} 85 \mathrm{H}^{\mathrm{C} 1}$ \\
\hline $\mathrm{A}+2-$ Hexanone $\mathrm{C}^{\mathrm{C}}$ & $20 / 80$ & 1.62 & 0.0910 & $\mathrm{~A} 65 \mathrm{H}^{\mathrm{C} 2}$ & $\mathrm{~A} 85 \mathrm{H}^{\mathrm{C} 2}$ \\
\hline $\mathrm{C}+2-$ Hexanone ${ }^{\mathrm{C} 2}$ & $50 / 50$ & 1.62 & 0.0364 & $\mathrm{C} 65 \mathrm{H}^{\mathrm{C} 2}$ & $\mathrm{C} 85 \mathrm{H}^{\mathrm{C} 2}$ \\
\hline
\end{tabular}

* Initial amount added in $100 \mathrm{~g}$ of starch-water mixture 


\subsubsection{Freeze-dried samples}

Heat-treated starch samples were frozen and stored at $-30{ }^{\circ} \mathrm{C}$ before freeze-drying (Triad, Labconco). The freeze-drying process was started from pre-freezing to $-75{ }^{\circ} \mathrm{C}$ for $3 \mathrm{~h}$ then the temperature was raised to $-30^{\circ} \mathrm{C}$ at $1{ }^{\circ} \mathrm{C} / \mathrm{min}$ and left constant there for $14 \mathrm{~h}$. Later the temperature was raised to $0{ }^{\circ} \mathrm{C}$ at $1{ }^{\circ} \mathrm{C} / \mathrm{min}$ and held for $36 \mathrm{~h}$. Finally, the temperature was raised to $25^{\circ} \mathrm{C}$ at $1{ }^{\circ} \mathrm{C} / \mathrm{min}$. The samples were left at $25^{\circ} \mathrm{C}$ for $40 \mathrm{~h}$ before being taken out of the freeze-drier for further experiment. As soon as the samples were taken from freeze-drier they were manually ground with a mortar. The ground samples were put in airtight containers and stored in desiccators for further experiments. Moisture contents of starch pastes after freeze-drying ranged from 0.0-1.6\% and were not statistically different.

\subsubsection{Moisture content and water activity analysis}

The moisture analysis of all samples (native starch, freshly prepared, freeze-dried and equilibrated samples) were measured. The measurement was done by classical oven method. All samples were weighted with precision balance (Precisa XT1220M-FR, Precisa Instruments Ltd.) and left 18-24 h in oven at $105{ }^{\circ} \mathrm{C}$ (Mammert). After that, the samples were taken to cool down in desiccators. The weight was re-measured when the sample reached room temperature. Percent ratio to dry basis of weight difference was reported as moisture content. The measurement was done by triplicate.

Water activity of the sample after freeze-drying (initial state) and after equilibration was measured as another parameter of water sorption. The measurement was done with chilled-mirror dew point technique (Series 3TE, Decagon Devices, Inc.).

\subsection{Differential Scanning Calorimetry study (DSC)}

DSC is a thermoanalytical technique measuring the difference in heat required to increase the temperature of sample compared to a thermally inert reference. The technique allows to characterise a sample thermal properties by means of its: melting point, enthalpy of melting, enthalpy of relaxation, heat capacity, crystallisation temperature, glass transition temperature and degradation temperature. In this study, the DSC was employed to measure gelatinisation properties (enthalpy and temperature of melting), enthalpic relaxation and glass transition temperature. All measurements were done on the same instrument and with the same conditions. 
These measurements were carried out on DSC8000 (Perkin Elmer, Norwalk, CT). The instrument was calibrated with indium. Aluminium hermetic pans and lids were used throughout the study (TA Instruments, Switzerland). Approximately 9-15 mg of fresh sample was put into DSC pan while an empty pan was used as reference. The measurement of each sample was done in triplicate. DSC temperature programming started from $20^{\circ} \mathrm{C}$, rose to $140{ }^{\circ} \mathrm{C}$ at $10^{\circ} \mathrm{C} / \mathrm{min}$ and held at $140{ }^{\circ} \mathrm{C}$ for $1 \mathrm{~min}$. After that, the system was cooled down at the same rate to initial temperature and held for $1 \mathrm{~min}$. Second heating was applied in the same conditions in order to differentiate reversible/irreversible phenomena. Flow rate of gas was $20 \mathrm{ml} / \mathrm{min}$. DSC thermograms were analysed with Pyris software for Windows (Version 11.0.0.0449, Perkin Elmer).

\section{Measuring residual native starch and gelatinisation properties}

To evaluate percentage of residual native starch, native wheat starch was mixed with water at different ratios according to the formulae, left to equilibrate under agitation for 1 h. After that, they were subjected to DSC analysis. The obtained enthalpies from the first heating scan were standardised per gram of dry starch. The obtained values were represented as energy required for the melting of native starch and expressed in J/g of dry weight. The peak temperature of the first endotherm was recorded as melting temperature of native wheat starch.

Freshly cooked samples were subjected to DSC and the obtained enthalpies from the first scan were used to calculate the required energy in the same manner as for native starch. Once the samples cooled down, they were subjected to DSC analysis directly to limit syneresis and retrogradation. The \% required energy (residual melting enthalpy) ratios between freshly cooked to native samples were compared according to their recipes and flavour addition. The obtained percentages were reported as percent content of relative residual native starch. The temperature of the endotherms were reported as melting temperature.

\subsection{Flavour analysis}

\subsubsection{Simultaneous distillation extraction method (Figure 3-2)}

Five grams (wet weight) of paste samples or 1 gram of freeze-dried samples were used per extraction and each sample was extracted in duplicate. Starch samples were put into 
$250 \mathrm{ml}$ round bottom flask together with $10 \mathrm{~g}$ of sodium chloride and $100 \mathrm{ml}$ of distilled water. Before the extraction, $2 \mu$ of methyl heptanoate were added to the sample as internal standard of extraction. In order to avoid bubble during extraction, approximately 1 $\mathrm{ml}$ of antifoam (Antifoam 204, Sigma-Aldrich; Steinheim, Germany) and glass beads were added into the sample flask. The sample flask was then installed onto Likens-Nickerson apparatus. 25 millilitres of dichloromethane (Sigma-Aldrich; Steinheim, Germany) were used as extraction solvent. Approximately $10 \mathrm{ml}$ of dichloromethane were added into LikensNickerson apparatus while the remaining was added into $50 \mathrm{ml}$ round bottom flask prior extraction. The sample flask was heated up to $185{ }^{\circ} \mathrm{C}$ while the solvent flask was heated at $70{ }^{\circ} \mathrm{C}$ and they were left to undergo extraction for $45 \mathrm{~min}$. Once the extraction was finished, dichloromethane phases were collected and reconstituted to $25 \mathrm{ml}$. $2 \mu$ l of ethyl octanoate were added to the reconstituted sample prior to injection into GC. Flavour quantification was done by comparing with standard injection.

\subsubsection{Verification of method performance}

During method establishment, extraction conditions such as extraction temperature and time, amount of sample were optimised. Before obtaining the final extraction method as mentioned in 3.4.1, the method was verified for its performance. Once the method performance was found to meet acceptable level, the method was then applied to studied sample.

\subsubsection{Linearity}

During the extraction method development, linearity study was done to ensuring that the working concentrations were in range of detection. It also permitted to confirm the behaviour of flavour compounds versus signal responses. Linearity of working range was done by injection of several concentration of each flavour in to GC-FID. The GCFID signal responses were plotted against concentration of the flavour. The two values showed linear relationship with $\mathrm{R}^{2}$ equal to 0.98 for both flavour compounds. Coefficient of determination $\left(R^{2}\right)$ of 0.98 explained that $98 \%$ of data fit with linear model $(y=a x+b)$. Therefore, the responses of GC-FID signals were in proportion with concentration of ethyl hexanoate and 2-hexanone and there was no saturated point in the working range. 


\subsubsection{Recovery of extraction and matrix influence}

Recovery of extraction was studied in order to understand the maximum extraction performance of the method. The study was first applied on aqueous solutions of the interested flavours and then in the presence of starch. Each flavour compound was dissolved in water and prepared at six concentrations (ethyl hexanoate: $0.44-2.62 \mathrm{mg} / \mathrm{ml}$, 2hexanone: $0.41-2.43 \mathrm{mg} / \mathrm{ml}$ ). The solution was well mixed. Five millilitres of the solution were taken and put into $250 \mathrm{ml}$ round bottom flask and used for extraction as in the conditions mentioned in 3.4.1.

Each flavour concentration was extracted minimum twice. The extracted samples were then injected to GC-FID. The signal obtained from each flavour concentration was used for calculation of extraction recovery. Percent recoveries of ethyl hexanoate and methyl heptanoate were $66 \%$ and $100 \%$, respectively. Percent recoveries of 2 -hexanone and methyl heptanoate were $92 \%$ and $99 \%$, respectively. Afterward, percent extraction recoveries of the flavours including internal standard were calculated and used as correction factor.

Flavour analyses were conducted on both: paste (starch gel) and freeze-dried sample forms. The two forms of sample resulted in different viscosity of extract solution. This brought about the concern on matrix influence. Another method performance verification was done by spiking technique. The freshly cooked and freeze-dried samples without flavour addition from every recipe were subjected to extraction. Ethyl hexanoate (8.73 $\mathrm{mg}$ ) was spiked and mixed with sample (prepared without flavour) in the extraction flask. Afterward, the flask was subjected to extraction process as mentioned above. The obtained concentrations of ethyl hexanoate at same fortified amount from different matrices were then compared. The averages of percent extraction recovery from 2 types of matrices, starch paste and freeze-dried sample were $96 \%$ and $94 \%$, respectively, meaning there were matrice influence during extraction. According to the linearity and high percent recovery from extraction of flavour solution, the spiking test in 2-hexanone could be discarded.

\subsubsection{Residual of extraction}

Second time extraction was applied to both fresh sample and freeze-dried sample with variation of sample recipe, to ensure the efficiency of extraction. This 
experiment was done on the sample after a first extracted, to verify that there was no flavour compound left after the first extraction. The same sample flask was used in the extraction while new solvent was added. It was found that there were no ethyl hexanoate, 2-hexanone as well as the internal standard of extraction (methyl heptanoate) left over from their first extraction.

The calculation of extracted quantities relied on percent recoveries of the flavour as well as internal standard. Therefore, the extracted quantities were standardised according to extraction recovery. The 3 parameters: linearity, \% recoveries (in flavour solution and high viscosity matrices) and extraction efficiency of method performance were in an acceptable range. This can be concluded that the established extraction method was reliable with a good performance. Extraction method was simplified as a schematic in Figure 3-2.

Sample $5 \mathrm{~g}$ ( $1 \mathrm{~g}$ for Freeze Dried) $+10 \mathrm{~g} \mathrm{NaCl}+100 \mathrm{ml}$ distilled $\mathrm{H}_{2} \mathrm{O}$ ( $250 \mathrm{ml}$ round bottom)

$2 \mu \mathrm{l}$ Methyl heptanoate (pure): $1^{\text {st }}$ internal standard<smiles>[3H][AlH2]</smiles>

Add $\sim 1 \mathrm{ml}$ drops of antifoam, glass beads

Add into Likens-Nickerson apparatus

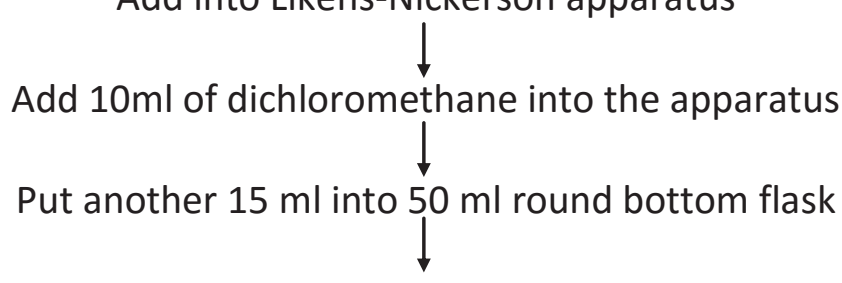

Subject to Likens-Nickerson apparatus

Leave to extract for $45 \mathrm{~min}$

(Temperature at solvent side $=70^{\circ} \mathrm{C}$, Sample side $=185^{\circ} \mathrm{C}$ )

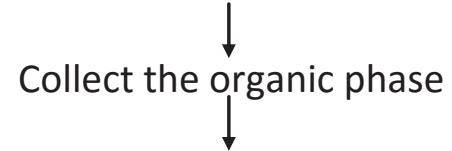

Add $2 \mu$ of ethyl octanoate ( $2^{\text {nd }}$ internal standard) into round bottom flask

Make up volume to $25 \mathrm{ml}$ with DCM

GC-FID

Figure 3-2: Simultaneous distillation extraction method 


\subsubsection{Gas Chromatography - Direct injection}

Gas chromatography (GC) was performed on Hewlett Packard 6890 - G1530A series Chromatography, which was equipped with flame ionisation detector (FID). The samples were introduced automatically by auto sampler (G1512AX) and injector HO6890 series. Volatile flavour compounds were separated on a silica capillary column (30 m x 0.32 mm i.d.) coated with carbowax $20 \mathrm{M}$ as stationary phase with a film thickness of $0.50 \mu \mathrm{m}$ (DB-Wax; Agilent J\&W Scientific, Folsom, CA). The carrier gas was ultra-high purity helium with constant flow rate of $1.5 \mathrm{ml} / \mathrm{min}$ and pressure of 7 psi. The split ratio of 25:1 was applied. FID make up gas flow was $15 \mathrm{ml} / \mathrm{min}$. $\mathrm{H}_{2}$ flow was $30 \mathrm{ml} / \mathrm{min}$ and airflow was $300 \mathrm{ml} / \mathrm{min}$. FID and injection temperature was $240^{\circ} \mathrm{C}$. GC temperature programming was started at 40 ${ }^{\circ} \mathrm{C}$, further increased by $5{ }^{\circ} \mathrm{C}$ per min to $100{ }^{\circ} \mathrm{C}$, finally increased $10{ }^{\circ} \mathrm{C}$ per min to $220^{\circ} \mathrm{C}$. Total run time was $22 \mathrm{~min}$. Data acquisition and analyses were performed with Star Chromatography Work Station Version 5.50 (Varian).

\subsection{Storage study}

Freeze dried samples were used for storage study in order to measure the effect of storage time on both flavour content and structural relaxation. Once the samples were ground, they were stored in controlled water activity atmosphere at $25{ }^{\circ} \mathrm{C}$. Saturated aqueous solutions of $\mathrm{NaCl}$, and $\mathrm{NaBr}$ were used for providing relative humidity of $75 \%$ and $58 \%$, respectively. The sample was first incubated in hermetic boxes for 2 weeks to allow the sample to equilibrate at $75 \%$ and $58 \% \mathrm{RH}$. Afterward, $200 \mathrm{mg}$ of each the sample were put into a $2 \mathrm{ml}$ vial which was placed in $20 \mathrm{ml}$ headspace vial containing $5 \mathrm{~g}$ of saturated salt (18 vials per recipe / relative humidity). The samples were stored at $25^{\circ} \mathrm{C}$, and then 6 vials were taken to be analysed at time interval (2, 4 and 14 weeks). The samples collected after 2 weeks were subjected to moisture content, Aw, DSC and HS-SPME analyses. Sample preparation for storage and flavour release upon storage is shown in Figure 3-3.

Each sample (approximately $10 \mathrm{~g}$ ) was divided into 3 portions of approximately $3 \mathrm{~g}$, and was separately put in small hermetic box with saturated salt solution. These 3 portions correspond to 3 interval times of sampling: 2, 4 and 14 weeks. 

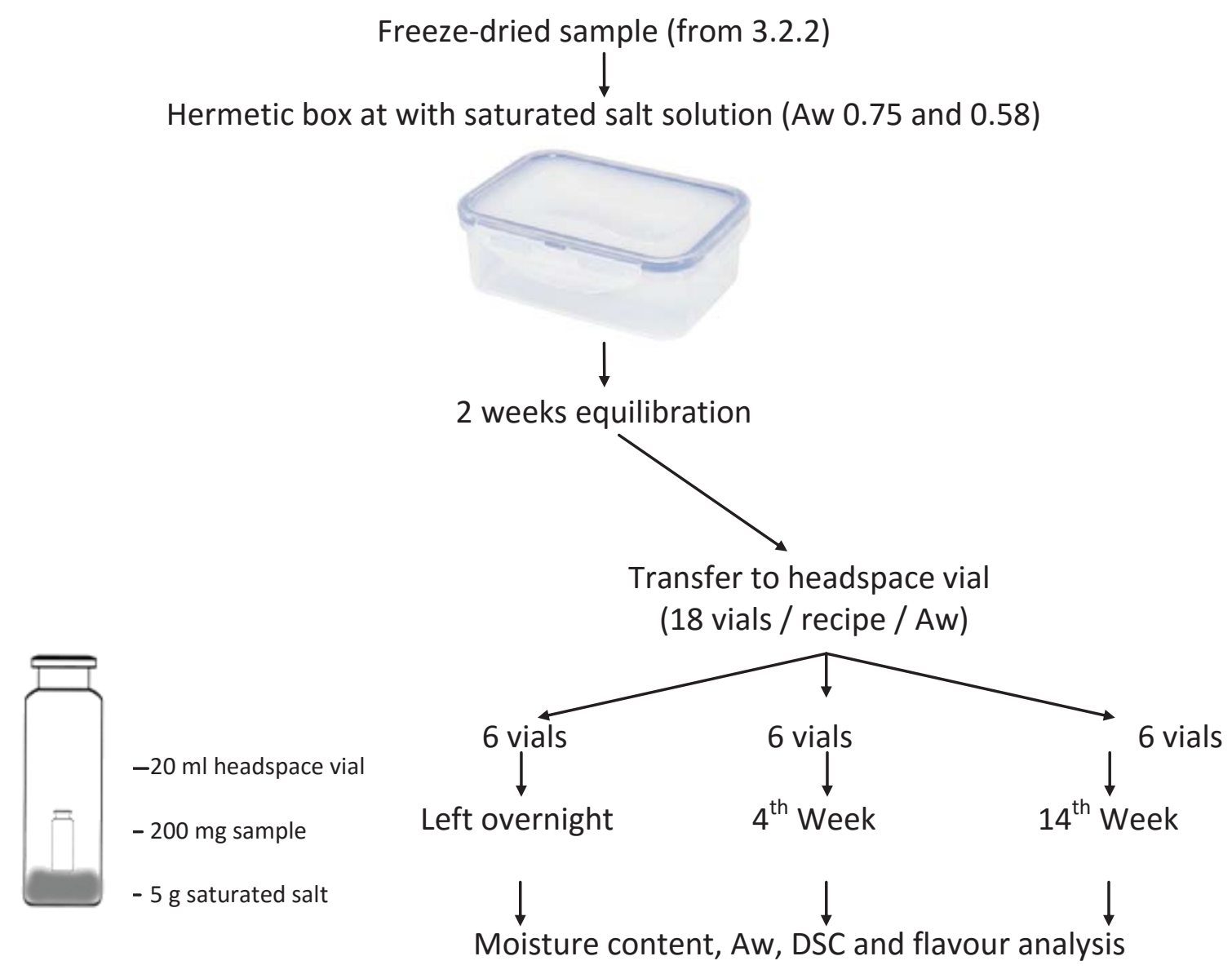

Figure 3-3: Schematic representation of the storage experimentation

\subsubsection{Glass transition temperature and enthalpy of relaxation}

The measurement was done on stored samples as mentioned in 2.5 to understand the sample evolution due to moisture and time effects. $T_{0}$ increase the sensitivity of measurement, the sample was compressed prior to analysis. $200 \mathrm{mg}$ of sample from each time interval of storage study was compressed by manual hydraulic press for $30 \mathrm{~s}$ under 5 tons (GS15011, Specac Limited) in $13 \mathrm{~mm}$ pellet die (Carver, Wabash Inc.) into a disk-liked shape. The sample tablets were crushed into small pieces. Approximately 9-15 mg of crushed pieces was put into DSC sample pan and subjected to DSC analysis (minimum 2 replications per each sample). The samples were scanned twice between 20 and $140{ }^{\circ} \mathrm{C}$ at $10^{\circ} \mathrm{C} / \mathrm{min}$.

\section{Enthalpy relaxation measurement}

The enthalpy obtained from the first heating cycle was reported as enthalpy of relaxation after storage. The thermogram of the first heating scan was used to determine 
the amount of enthalpy relaxed during storage, evaluating the difference between the thermograms of the first scan and that of the subsequent heating scan.

\section{Glass transition temperature measurement}

The glass transition temperature was measured at the mid-point of the observed heat capacity change on the second heating scan once the effect of thermal history had been erased by the first scan.

\subsubsection{Analysis of flavour retention and release upon storage by headspace SPME (HS-} SPME)

This experiment was done in order to understand the stability of the added flavour upon storage at $58 \%$ and $75 \%$ percent relative humidity. The study consists of 2 parts: flavour retention (by mean of extractable quantity) and flavour release (by headspace analysis). Samples from 2.5, were subjected to simultaneous distillation extraction as mentioned in 3.4.1, after different storage times (2, 4 and 14 weeks).

HS-SPME was performed on Varian Chromopack - 3800 chromatography, which was equipped with flame ionisation detector (FID). The samples were introduced automatically by auto sampler CombiPal (CTC Analytics MB01-00A) and injector (MXY 20-00B). DVB/CAR/PDMS 50/30 $\mu \mathrm{m}$ coated fibre was chosen for the study. The fibre was purchased from Supelco (Bellefonte, USA). Prior analysis, fibre was conditionned for $1 \mathrm{~h}$. The sample was left to equilibrate at room temperature and taken for analysis at time interval $(2,4$ and 14 weeks) without agitation. The fibre was introduced by piercing through the vial septum with the needle containing fibre and adsorb the gas phase for $5 \mathrm{~min}$. The extracted analytes were desorbed in the injection port of GC-FID for 26 min time which also covered reconditioning of the fibre prior another injection.

Volatile flavour compounds were separated on a silica capillary column (30 m x $0.32 \mathrm{~mm}$ i.d.) coated with carbowax $20 \mathrm{M}$ as stationary phase with a film thickness of 0.50 $\mu \mathrm{m}$ (DB-Wax; Agilent J\&W Scientific, Folsom, CA). The carrier gas was ultra-high purity helium with constant flow rate of $1.5 \mathrm{ml} / \mathrm{min}$ and pressure of $7 \mathrm{psi}$. The splitless was applied. FID make up gas flow was $15 \mathrm{ml} / \mathrm{min}$. $\mathrm{H}_{2}$ flow was $30 \mathrm{ml} / \mathrm{min}$ and airflow was 300 $\mathrm{ml} / \mathrm{min}$. FID and injection temperature was $240{ }^{\circ} \mathrm{C}$. GC temperature programming was started at $40{ }^{\circ} \mathrm{C}$, further increased by $5^{\circ} \mathrm{C}$ per min to $100{ }^{\circ} \mathrm{C}$, finally increased $10{ }^{\circ} \mathrm{C}$ per min 
to $220^{\circ} \mathrm{C}$. Total run time was $22 \mathrm{~min}$. Data acquisition and analyses were performed with Star Chromatography Work Station Version 5.50 (Varian).

\subsection{Starch pasting profile study}

The data collected through the RVA analysis consist in both the temperature and the viscosity of the starch suspension versus time. A 3-step-thermal treatment is applied to the suspension, which can cause the viscosity to evolve. The viscosity changes upon treatment are called "pasting profile" and are used by the software (Thermocline ${ }^{\circledR}$ ) to determine different points of the RVA profile versus time: pasting temperature, peak viscosity, trough, breakdown, setback, final viscosity and pasting time. Figure 3-4 represents a typical complete RVA curve. Pasting temperature is the initial point of the viscosity increase. Peak viscosity is the highest apparent viscosity developed during the heating/holding phase of the test and reflects the water-holding capacity. Trough or holding strength is the minimum viscosity or viscosity throughout heating period. Final viscosity is the viscosity at the end of the test and it correlates with the ability to form a viscous paste or gel after cooking and cooling. Breakdown is derived from peak viscosity minus trough viscosity and represents paste stability upon heating and shear. Setback is derived from final viscosity minus peak viscosity and represents re-association of starch molecule upon cooling (Batey \& Bason, 2007; Biliaderis, 2009).

To preserve structural properties of starch pastes, the samples were freeze-dried after their hydrothermal treatment and prior to their analysis with RVA. Starch pasting profiles were analysed by Rapid Visco ${ }^{\mathrm{TM}}$ Analyser: RVA ${ }^{\mathrm{TM}}$ Super 4 (Newport Scientific Warriewood, Australia). The instrument was calibrated with the standard starch provided by instrument manufacturer ( $3.5 \mathrm{~g}$ per $25 \mathrm{ml}$ of deionised water). For all samples $3 \mathrm{~g}$ of sample were used and the water content adjusted to a final value of $90 \%$ dry basis. Each starch sample was mixed with $25 \mathrm{ml}$ of deionised water in canister and equally shaken prior to be placed into the instrument. RVA was programmed to agitate the sample at $960 \mathrm{rpm}$ for $10 \mathrm{~s}$, then at 160 rpm where the agitation was kept constant. Starch suspension was initially heated at $50{ }^{\circ} \mathrm{C}$ and raised to $95{ }^{\circ} \mathrm{C}$ in $3 \mathrm{~min}$ and $42 \mathrm{~s}$. After that, the temperature was maintained at $95{ }^{\circ} \mathrm{C}$ for $2.5 \mathrm{~min}$ before cooling to $50^{\circ} \mathrm{C}$ over $3 \mathrm{~min}$ and $48 \mathrm{~s}$. The values of peak viscosity, trough and final viscosity were recorded. The values of breakdown and set back were calculated 
automatically by Thermocline software integrated in the instrument. All analyses were done in triplicate.

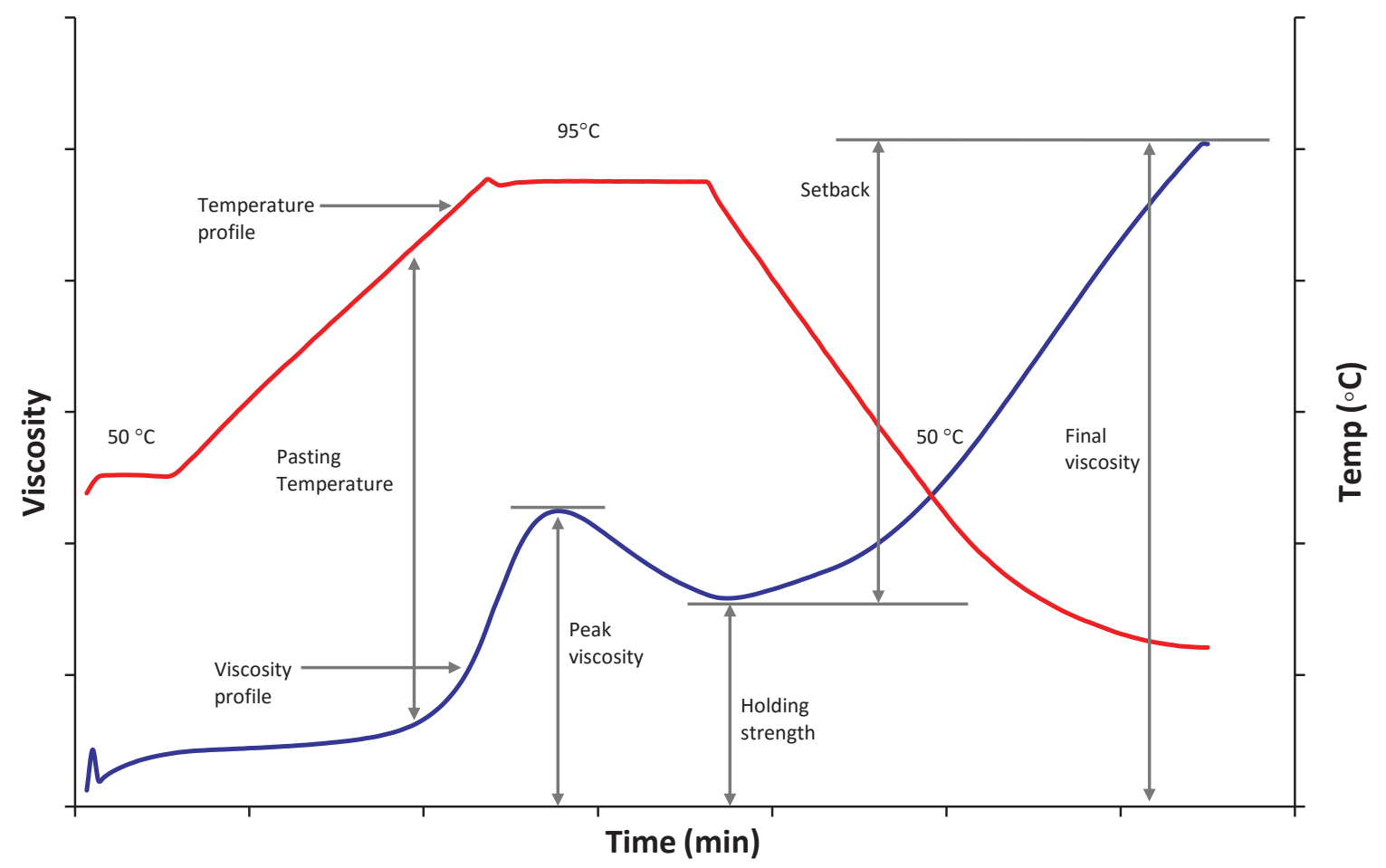

Figure 3-4: Typical complete RVA curve, showing the main parameters used to describe pasting (Batey, 2007).

\subsection{Granule size study}

Freeze-dried samples from 3.2.2 were subjected to granule size distribution measurement. Ground freeze-dried powder was mixed with $95 \%$ ethanol $(0.1: 10 \mathrm{ml} \mathrm{g} / \mathrm{ml})$ to avoid water sorption during the measurement. The mixture was subjected to sonication to limit particle aggregation. The sonication was done for $30 \mathrm{~min}$ under cool temperature to avoid destruction and swelling of starch sample. The samples suspension was measured by Malvern Mastersizer 2000 laser-diffraction analyser (version 5.22, Mavern Instruments Ltd, Malvern, UK) using a flowthrough, $200 \mathrm{ml}$ reservoir. A general proposed analysis model was used with particle refractive and absorption indices of 1.52 and 0.1 (Mahasukhonthachat, Sopade, \& Gidley, 2010) while the reflective index of ethanol was 1.36. The sample was agitated in reservoir at $2000 \mathrm{rpm}$. The sample suspension was added into sample reservoir until obtaining obscuration value of $12-17 \%$. Settings were optimised for the refractive index of starch in ethanol and an average of three consecutive measurements performed. The 
Fraunhofer approximation was used for calculation of the starch granules size distribution and the corresponding volume fraction-length mean diameter ( $d 4,3$ ).

The measurement based on volume weighted particle size distribution $D[4,3]$ (e.g. laser diffraction) is often to report parameters based on maximum particle size for a given. The percentiles are defined as $\mathrm{XaB}$ where:

$\mathrm{X}=$ parameter, usually $\mathrm{D}$ for diameter

$\mathrm{a}=$ distribution weighting, e.g. $\mathrm{n}$ for number, $\mathrm{v}$ for volume, I for intensity

$B=$ percentage of sample below this particle size e.g. $50 \%$, sometimes written as a decimal fraction i.e. 0.5

The most common percentiles reported are the Dv10, Dv50 and Dv90 (Figure 3-5). The monitoring of three parameters allows seeing the significant changes in the main particle size, as well as the changes at the extremes of the distribution (Anonymous, 2012).

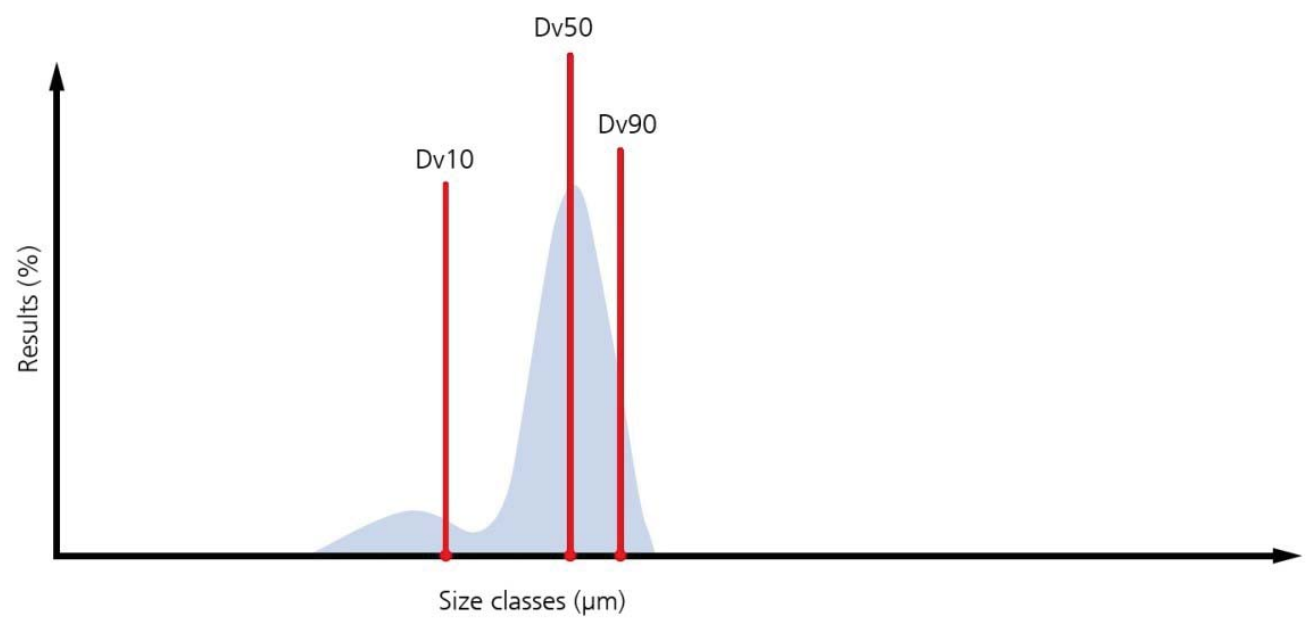

Figure 3-5: Illustration of the Dv10, Dv50 and Dv90 on a typical particle size distribution where significant proportion of fines are present (Anonymous, 2012)

\subsection{X-ray Diffraction Crystallography (XRD)}

XRD was performed on freeze-dried samples (3.2.2) to determine their crystalline type and the relative crystallinity. The diffractometer (X'Pert MPD, Philips, Netherlands) was operated at $40 \mathrm{kV}$ and $30 \mathrm{~mA}$ with a $\mathrm{CuK}_{\alpha}$ radiation with a wavelength of $0.154 \mathrm{~nm}$ as the X-

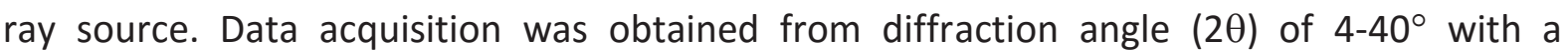
scanning speed $1.2 \% \mathrm{~min}$ and scanning step of $0.05^{\circ}$. The obtained diffraction diagrams were normalised to the same total integrated area of $4-40^{\circ}(2 \theta)$. 
This analysis was performed at Scientific Equipment Center, Prince of Songkla University as a part of PHC Siam - Hubert Curien Project (Franco-Thaï Collaboration).

\subsection{Wide Angle X-ray Scattering (WAXS) and Small Angle X-ray Scattering (SAXS)}

WAXS and SAXS measurements were performed at BL1.3W of the Siam Photon Laboratory, Synchrotron Light Research Institute (Public Organization) (SLRI), Nakhon Ratchasima, Thailand, to study crystalline structure and orientation. WAXS is an equivalent and exchangeable technique to XRD. Although the degree of relative crystallinity can be achieved by XRD technique, the additional study by WAXS is to compare data acquisition of the two techniques. The advantage of this WAXS analysis is the source of X-ray, which is from Synchrotron. The high energy source and high sensitivity detector resulted in high resolution information.

\subsubsection{Wide Angle X-ray Scattering (WAXS)}

Ground freeze-dried starch was smeared on polyimide film (Kapton ${ }^{\circledR}$ tape, Lanmar Inc. USA) and subjected to WAXS measurement. The X-ray energy was at $9.5 \mathrm{keV}$ and the wavelength is $0.13 \mathrm{~nm}$. The calibration of sample to detector distance was done with 4bromobenzoic acid standard. The sample was placed at $20.14 \mathrm{~cm}$ from detector. Scattering patterns were recorded by Image Plate Mar345, with the pixel size of $0.15 \mathrm{~mm}$. The resultant 1D scattering profiles from each measurement were normalised to obtain the same total integrated area within 5-40 $(2 \theta)$. Data analysis was done by SAXSIT version 3.69 software developed by BL1.3W at SLRI.

\subsubsection{Small Angle X-ray Scattering (SAXS)}

SAXS allows the study of structure and the changes under subgranular level, the visible peak represents the thickness of lamella. The thickness of lamella is derived from scattering vector (q) (Blazek \& Gilbert, 2011; Pikus, 2005). Peak area and peak location analysis inform on lamellar repeat distance, fractional lamellar crystallinity, electron density difference between the three regions of starch granule, and etc. (Pikus, 2005). SAXS of hydrated granular starch revealed a characteristic low-angle scattering peak, which resulted from alternating lamellae of loosely and densely packed material with a repeat distance of 9-11 $\mathrm{nm}$ (Vermeylen, Goderis, Reynaers, \& Delcour, 2004). SAX scattering profile derives from 
heterogeneities in electron density from other regions. These together with liquid crystal (smectic, nematic, isotropic) approach allow understanding the change of starch structure upon treatments (Cameron \& Donald, 1992; Cameron \& Donald, 1993a, 1993b; Jacobs et al., 1998; Pikus, 2005). The change after annealing can be observed by SAXS (Cameron \& Donald, 1992; Jacobs, et al., 1998), as seen in Figure 3-6. Low-angle intensity increases with time and the peak becomes progressively less well defined. All the curve of the annealed sample lies above that of the native ones (Cameron \& Donald, 1992). According to this research, SAXS elucidates water absorption effect and well as the disruption of crystallinity (Cameron \& Donald, 1992). There are several studies on starch gelatinisation by SAXS technique as well as upon hydrothermal treatment at various hydration degrees (Cameron \& Donald, 1993a; Derycke, et al., 2005; Vermeylen, Derycke, et al., 2006; Vermeylen, Goderis, et al., 2006; Vermeylen, Goderis, Reynaers, \& Delcour, 2005; Waigh, Gidley, et al., 2000). Although the basic information from SAXS is the scattering vector, mathematic data processing help obtaining further information such as the length of crystalline and amorphous lamellae (Cameron \& Donald, 1992; H-K. Huang, et al., 2014). SAXS can be used for other purpose such as bread ageing study. In this case, the starch is fully gelatinised therefore no peak is observed.

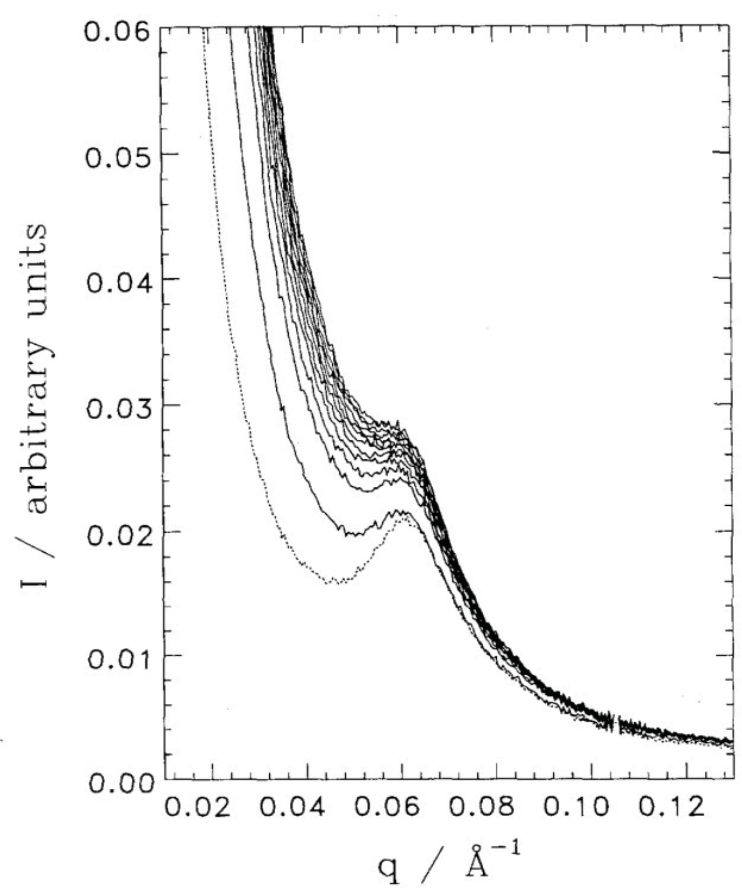

Figure 3-6: Change in the SAXS intensity profile of a $45 \%$ starch slurry held at $51{ }^{\circ} \mathrm{C}$. The data are binned at $5 \mathrm{~min}$ intervals from bottom (room temperature) to top (longest annealing time) (Cameron \& Donald, 1992). 
Ground freeze-dried samples were mixed with distilled-water at the ratio 1:1 (w/w) to increase electron density contrast between amorphous and crystalline starch. According to Cameron and Donald, (1992), the hydration alternates crystalline and amorphous lamellae of amylopectin that cannot be distinguished in dried starch. Each sample was prepared only a short time prior to analyse to avoid retrogradation. The hydrated starch was smeared on polyimide film (Kapton ${ }^{\circledR}$ tape, Lanmar Inc. USA) and subjected to SAXS measurement. The sample was placed at $1.83 \mathrm{~m}$ from detector. The patterns were recorded by the Rayonix SX165 CCD detector and resulted in scattering vector, $q$, defined as $q=(4 \pi / \lambda) \sin (\theta)$, where $2 \theta$ is the scattering angle. The calibration of the sample to the detector distance was done with silver behenate $\left(\mathrm{AgC}_{22} \mathrm{H}_{43} \mathrm{O}_{2}\right)$. The resultant $1 \mathrm{D}$ scattering profiles from each measurement were normalised to obtain the same total integrated area within the $q$ range between $0.2-2 \mathrm{~nm}^{-1}$. Data analysis was done by SAXSIT version 3.69 software developed by BL1.3 at SLRI.

\subsubsection{Data analysis by SAXSIT software}

SAXSIT (Small Angle X-ray Scattering Image Tool) is a SAXS/WAXS processing software. The software has been developed by BL1.3 at SLRI under Matlab ${ }^{\circledR}$. The software can be operated without Matlab ${ }^{\circledR}$ installation as it was compile into executable modules (Soontaranon and Rugmai, 2012). It also provides output in Microsoft Excel spreadsheet format to facilitate further data processing (Soontaranon and Rugmai, 2012). SAXSIT was applied for the analysis of pattern alignment, calibration of sample-detector distance, background substraction, circular averaging and radial integration of the profile. Although, the software is in-house developed, it is open access and available to download at http://www.slri.or.th/th/index.php?option=com_content\&view=article\&id=276:saxsitpage $\&$ catid $=55:$ bl22\&ltemid $=85$.

\subsection{Fourier transform infrared spectroscopy (FTIR)}

Freeze-dried samples from 3.2.2 were subjected to FTIR. Prior to analysis, $4 \mathrm{mg}$ of each sample was mixed with $\mathrm{KBr}$ (Merck, Darmstadt, Germany) and die-cast under 5 tons for $30 \mathrm{~s}$ into $13 \mathrm{~mm}$ disc-like shape. The pellet compression was done with automatic 
hydraulic press (Auto-CrushIR, PIKE Technologies, Wisconsin). The sample pellets were subjected to FTIR Spectrometer Vector 70 (Bruker, Hong Kong). Spectra were obtained in the transmission mode between 2000 and $800 \mathrm{~cm}^{-1}$ at $4 \mathrm{~cm}^{-1}$ interval. The obtained spectra were baseline corrected and normalised (OPUS software, version 7.2). The measurement were performed at BL4.1 IR spectroscopy SLRI.

\subsection{Statistical analysis}

All statistical analysis conducted by XLSTAT $^{\text {TM }}$ software for Windows ${ }^{\circledR}$ Version 2013.1.02 (Addinsoft Inc, France). ANOVA was used to determine significant difference and variation of samples and treatments. Principle component analysis (PCA) was applied to determine correlation between pasting profile and others factors. 
Chapter 4: Results and discussion 
According to the objectives and rationale of the study that focus on interactions between starch and flavour upon hydrothermal treatment at intermediate hydration and temperature, the results and discussion chapter is divided into 2 parts. The first part is dedicated to the direct effect of hydrothermal treatment on the prepared sample i.e. in regard of starch-flavour interaction, pasting properties, granular and structure characteristics. The second part is concerned with the stability upon storage of the resultant samples by mean of flavour retention and release as well as structural relaxation studies.

\subsection{Effect of hydrothermal treatment}

\subsubsection{Flavour residual content upon hydrothermal treatment}

Sample pastes were subjected to Likens-Nickerson extraction. The extracted amount of flavour compound ranged from 0.38-1.12 mg/g starch (dry basis), from 0.23-1.28 and from 1.51-12.74 mg/g starch (dry basis) for ethyl hexanoate, 2-hexanone $\mathrm{C} 1$ and 2hexanone $\mathrm{C} 2$, respectively (Table 4-1). The flavour residual content in the starchy matrices was reported as percent ratio to initial concentration (Figure 4-1). The overall results suggested that water content upon thermal treatment influenced flavour residual content. In excess of water (recipe A), cooking at $65{ }^{\circ} \mathrm{C}$ induced significantly less flavour loss compared to cooking at $85{ }^{\circ} \mathrm{C}$. The higher flavour loss in A85 might be due to the couple high hydration and temperature favouring the mass transfer compared to the other conditions. High temperature treatment contributed to a more important flavour loss possibly caused by a greater evaporation in the open system.

Comparing between $\mathrm{C}$ samples, there was no significant difference in ethyl hexanoate and 2-hexanone $\mathrm{C} 1$ residual contents while there was a significant difference in 2-hexanone C2 residual content. Although the initial amount of 2-hexanone had been increased (2hexanone C2), C65 was found to contain lower percent residual than C85. It could be speculated that the coupling of low hydration and temperature did not favour starch-flavour interaction. Since the initial amount of 2-hexanone was increased, this drove C65 sample to exhibit a phase separation and facilitated flavour loss during heating since the flavour was poorly dissolved. C85 contained the same amount of water as C65, but the higher temperature compensated and helped promoting a better starch-water-flavour dissolving than at $65{ }^{\circ} \mathrm{C}$ (Waigh, Gidley, et al., 2000). Under limiting water conditions, the higher gelatinisation the greater flavour retention. 
Table 4-1: Amount of residual flavour in fresh sample in $\mathrm{mg} / \mathrm{g}$ of dry weight - average value from 3 sample preparations

\begin{tabular}{lccc} 
Sample & \multicolumn{3}{c}{ Flavour residual in $\mathrm{mg} / \mathrm{g}$ dry weight } \\
\cline { 2 - 4 } & Ethyl hexanoate & 2-Hexanone C1 & 2-Hexanone C2 \\
\hline A65 & $1.12 \pm 0.12$ & $1.08 \pm 0.29$ & $12.74 \pm 2.53$ \\
A85 & $0.38 \pm 0.08$ & $0.23 \pm 0.08$ & $2.08 \pm 0.31$ \\
C65 & $0.71 \pm 0.11$ & $0.45 \pm 0.04$ & $1.51 \pm 0.44$ \\
C85 & $0.78 \pm 0.04$ & $0.37 \pm 0.10$ & $4.97 \pm 0.17$ \\
\hline
\end{tabular}

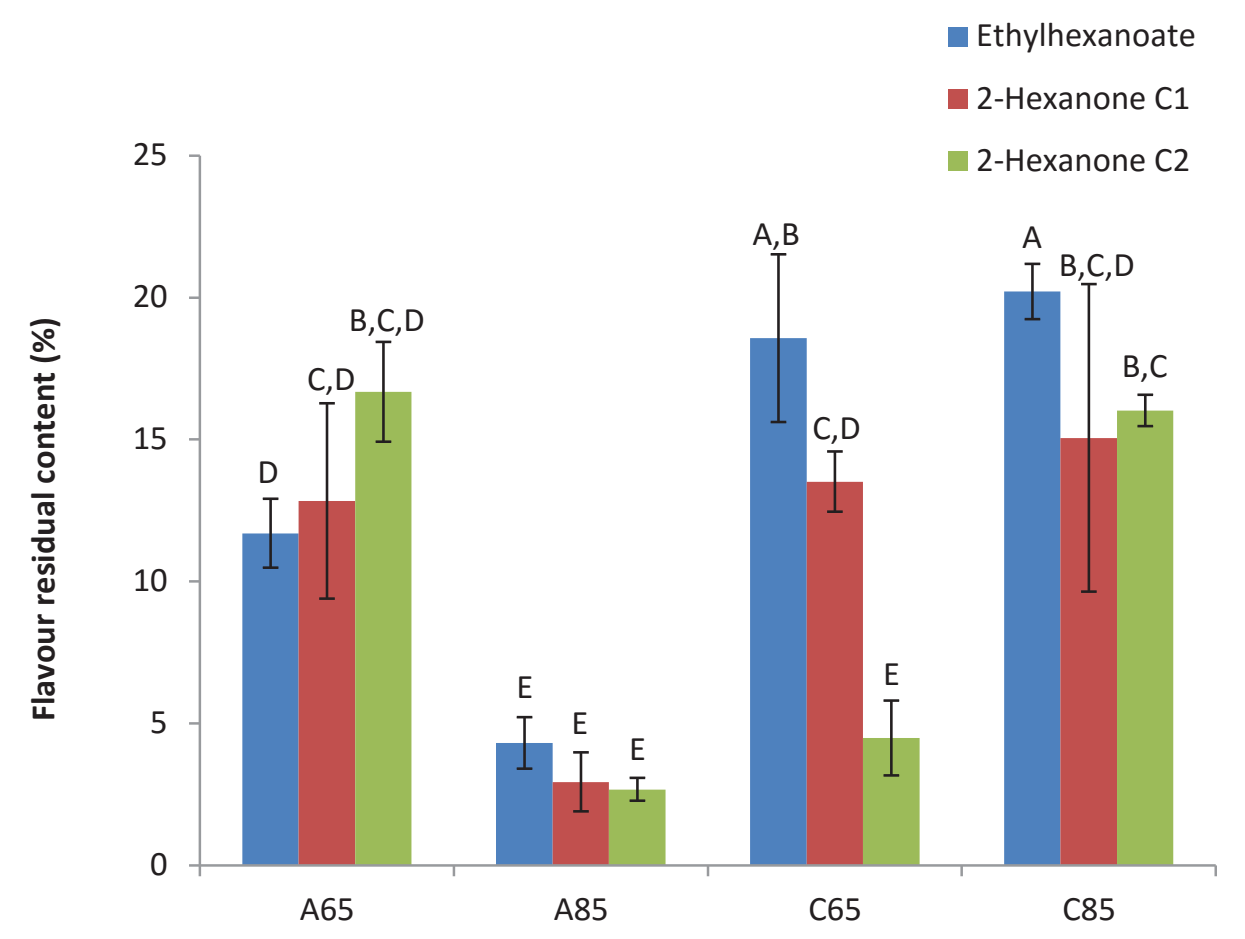

Figure 4-1: Extracted flavour after cooking as percent of initial - Different labels in capital letters indicate significant difference $(P<0.001)$ at $95 \%$ confidence interval by Fisher's LSD test.

The residual flavour content was also determined on the freeze-dried prepared samples. The extracted amount of flavour compound ranged from $0.42-1.12 \mathrm{mg} / \mathrm{g}$ starch dry basis), from 0.28-1.17 and from 2.77-20.40 mg/g starch (dry basis) for ethyl hexanoate, 2hexanone $\mathrm{C} 1$ and 2-hexanone $\mathrm{C} 2$, respectively (Table 4-2). 
Table 4-2: Amount of residual flavour in freeze-dried samples in $\mathrm{mg} / \mathrm{g}$ of dry weight - average value from 3 sample preparations

\begin{tabular}{lccc} 
Sample & \multicolumn{3}{c}{ Flavour residual in $\mathrm{mg} / \mathrm{g}$ dry weight } \\
\cline { 2 - 4 } & Ethyl hexanoate & 2-Hexanone C1 & 2-Hexanone C2 \\
\hline A65 & $1.08 \pm 0.12$ & $1.17 \pm 0.40$ & $20.40 \pm 2.26$ \\
A85 & $0.42 \pm 0.17$ & $0.28 \pm 0.07$ & $3.70 \pm 0.20$ \\
C65 & $1.12 \pm 0.01$ & $0.48 \pm 0.06$ & $2.77 \pm 0.22$ \\
C85 & $0.76 \pm 0.16$ & $0.45 \pm 0.10$ & $5.81 \pm 1.02$ \\
\hline
\end{tabular}

During trial experiment on extraction of freeze-dried samples, it was found that the residual of 2-hexanone C1 was slightly low. Therefore, the added amount of 2-hexanone was increased by 10 times to facilitate the further experiments. Comparing the residual amount before and after freeze-drying, it can be implied there was no significant flavour loss due to freeze-drying, which is in agreement with the study of (Wulff, Avgenaki, \& Guzmann, 2005). The difference in residual flavour contents between each sample at wet and freeze-dried states were due to different batches and extraction error. Preliminary experiments showed no difference in extraction performance between matrices. However, the matrix influence study was performed by fortifying known amount of flavours into extraction flask containing different type of matrix whereas the flavours were integrated with starch for the case of real samples. This probably caused the difference in extraction performance between wet and freeze-dried samples. The slightly higher residual flavours in freeze-dried sample could be due to batch difference between wet and freeze-dried samples.

\section{Box 1: 4.1.1 Section highlight}

- At high hydration, flavour loss was due to heating temperature and vapourisation.

- Flavours can interact with starch at similar rate (at the same temperature and hydration level).

- There was no significant flavour loss due to freeze-drying.

\subsubsection{DSC measurement of semi-crystalline sample and residual native starch}

Figure 4-2 shows the DSC thermograms of native wheat starch at two different starchwater ratios with and without aroma compound recorded on the first heating scan. A single 
endotherm with trailing was found for all starch-water ratios and flavour additions. Cooking starch at limiting water has been described to exhibit a multiphase endotherm (Baks, Ngene, van Soest, Janssen, \& Boom, 2007; Biliaderis, 1992; Jang \& Pyun, 1996) (Jouquand, et al., 2006). However, the water threshold to observe two separate endotherms for wheat starch has been described to be below 55\% moisture content, which was below the lowest water considered in this work (C samples) (Rolee \& Le Meste, 1999) which probably explained the trailing shape rather than a clear double endotherm.

Figure 4-3 shows the melting thermograms of freshly cooked samples. There were small single endotherms observed in A65 samples, except A65 with 2-hexanone C2. Multiple endotherms can be observed in C65 and C85 with and without flavour. The DSC results clearly showed that only A85 and C65 with 2-hexanone C2 were fully gelatinised. Enthalpies of native wheat starch and cooked starch are shown in Table 4-3. According to literature data, enthalpy of native wheat starch may range from 9 to $18 \mathrm{~J} / \mathrm{g}$ (Baks, et al., 2007; Jenkins \& Donald, 1996; Ratnayake, et al., 2008; Rolée \& Le Meste, 1997) (Tester, et al., 1998). Those studies measured gelatinisation enthalpy for wheat starch only without flavour addition at various moisture contents.

In the present work, the enthalpies obtained for native wheat starch ranged from 4.5 to $10.4 \mathrm{~J} / \mathrm{g}$. It is noteworthy that gelatinisation enthalpies of native starch at the highest hydration level (A) were significantly reduced in presence of 2-hexanone whereas the enthalpies for recipe $\mathrm{C}$ remained similar to literature data with or without flavour. This might be explained by competition for water between starch and 2-hexanone. The latter has a much higher aqueous solubility $(16.2 \mathrm{~g} / \mathrm{L})$ at $25^{\circ} \mathrm{C}$ than ethyl hexanoate has $(0.65 \mathrm{~g} / \mathrm{L})$, (Covarrubias-Cervantes, et al., 2005a). Regarding the samples (A and C) with 2-hexanone C1, the concentrations of 2-hexanone (2.0 and $3.2 \mathrm{~g} / \mathrm{l}$ of water respectively) were below solubility limit whereas they were above the limit for ethyl hexanoate. The property of water acting as solvent in the system might be altered due to dissolved flavour compounds. As a consequence this difference in solvent water could affect the gelatinisation enthalpy. Finally, the substrate concentration, through the availability of water, could also be another possible reason for the lower enthalpy of recipe A sample in presence of 2-hexanone. Indeed the solubility of flavour compounds in carbohydrate solutions has been suggested to decrease when the substrate concentration increased (Covarrubias-Cervantes, et al., 2005a; Covarrubias-Cervantes, Bongard, Champion, \& Voilley, 2005b). Starch concentration was 
higher in recipe $C$ than in $A$, it could lower the solubility of 2-Hexanone which would then lead to the same effect. Moreover, Covarrubias-Cervantes et al. (2005b) showed that aroma water solubility decreased when aroma hydrophobicity increased and in this case, ethyl hexanoate (Log $P=2.80$ (Savary, Lafarge, Doublier, \& Cayot, 2007) exhibits a higher hydrophobicity than 2-hexanone (Log $P=1.38$ (Jouquand, et al., 2004). When the samples at the 2 levels of 2 hexanone are compared, while both concentrations ( 20 and $32 \mathrm{~g} / \mathrm{l}$ of water) were above solubility limit, no significant difference in melting enthalpy was observed between them. The higher amount of 2-hexanone did not significantly influence the enthalpy but it significantly increased the melting temperature.

It is expected to see the endothermic event at $\sim 105^{\circ} \mathrm{C}$ in the samples with ethyl hexanoate since it is report to form inclusion complex with starch. However, there was no amylose-lipid complex and flavour-inclusion complex detected by DSC. This probably due to low amount of flavour added, the conditions did not favour the formation of complex or the amount was too low to be detected. Nuessli et al., (1997) found that decanal was unable to form a complex with starch but on the contrary gave exothermic phase transition upon heating. Hence, lowering of enthalpy of recipe $A$ in the presence of 2-hexanone to $4.5 \mathrm{~J} / \mathrm{g}$ might be due to compensation between exothermic and endothermic events. In the study of Nuessli et al., (1997), thermal analysis was done on heat-treated sample while the present study was done with native starch, the exothermic event possibly occurred at lower temperature in their work. Figure 4-2 shows that there is an exothermic event starting at $\sim 105{ }^{\circ} \mathrm{C}$. Considering recipes $\mathrm{A}$ and $\mathrm{C}$, this event was more clearly exothermic for recipe $\mathrm{A}$ than $\mathrm{C}$. These exothermic phase transitions were greater with 2-hexanone in both recipes but were broader and wider in A than in C samples. These exothermic events disappeared between the first and second DSC heating scans in agreement with Nuessli et al., (1997). These assumptions would require more study of the involved flavour-starch interaction to explain this exothermic behaviour.

Although no flavour-inclusion complex could not be detected, either there could still be some, or flavour could be trapped between amylose helices (Biais, et al., 2006). 


\section{Box 2: 4.1.2 Section highlight}

- Melting enthalpy of native wheat starch is reported for the first time to be affected by flavour addition.

- At high hydration level, there was no residual of native starch while there were $12-50 \%$ residual of native starch at lower hydration.

- No flavour inclusion complex can be detected by DSC which might be due to low flavour concentration or no formation of the complex. 


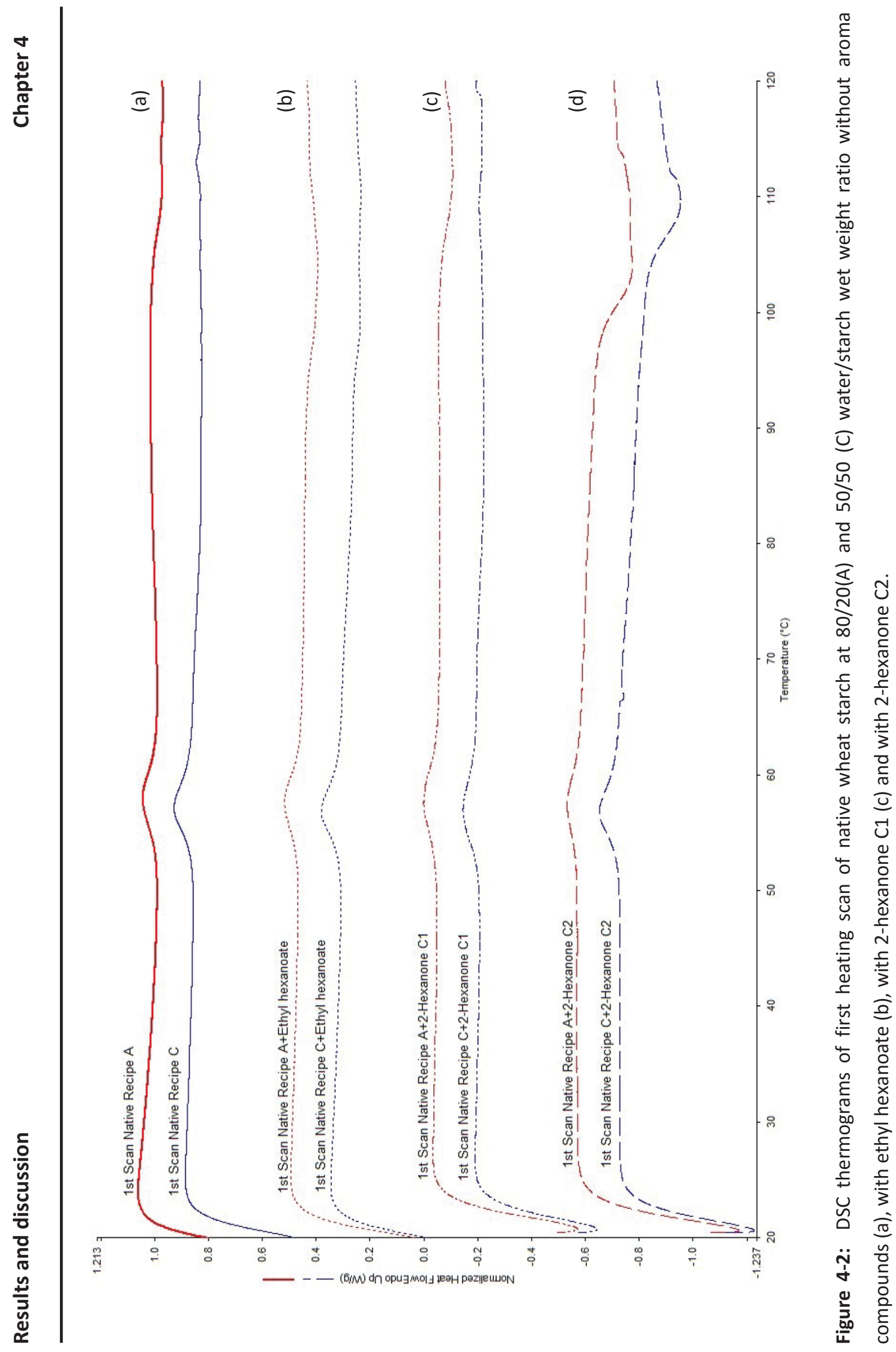




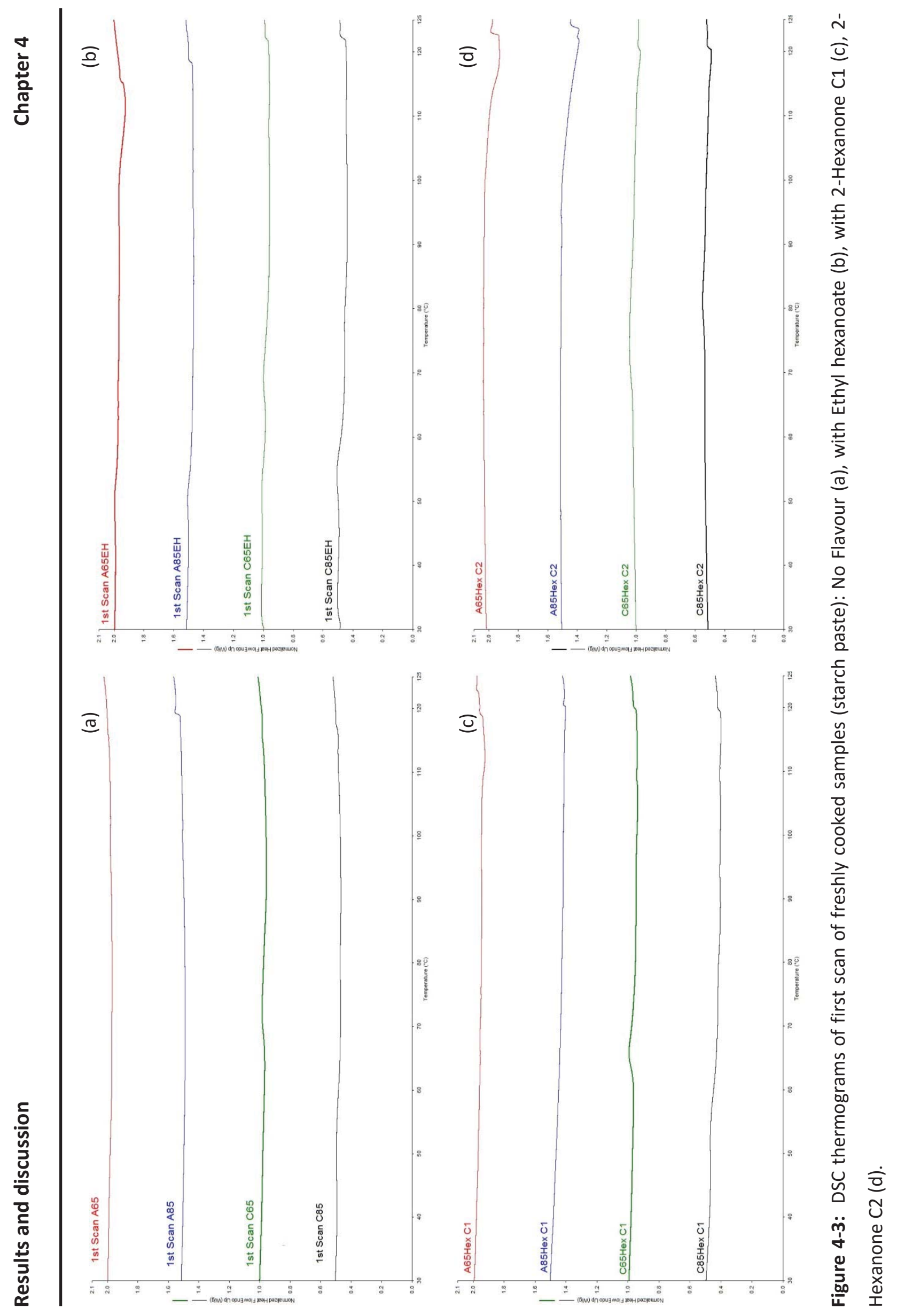


Table 4-3: DSC thermal properties and residual of native starch in starch paste

\begin{tabular}{|c|c|c|c|c|c|c|}
\hline $\begin{array}{l}\text { Sample } \\
\text { recipe }\end{array}$ & $\begin{array}{l}\text { Heating } \\
\text { Temp. } \\
\left({ }^{\circ} \mathrm{C}\right)\end{array}$ & $\begin{array}{c}\text { Onset Temp } \\
\left({ }^{\circ} \mathrm{C} \pm \mathrm{SD}\right)\end{array}$ & $\begin{array}{l}\text { Peak Temp } \\
\left({ }^{\circ} \mathrm{C} \pm \mathrm{SD}\right)\end{array}$ & $\begin{array}{c}\text { Conclusion } \\
\text { Temp } \\
\left({ }^{\circ} \mathrm{C} \pm \mathrm{SD}\right)\end{array}$ & $\begin{array}{l}\text { Enthalpy } \\
\text { (J/g士SD) }\end{array}$ & $\begin{array}{c}\text { \% Residual } \\
\text { Native } \\
\text { starch* }\end{array}$ \\
\hline$A$ & \multirow{4}{*}{ NA } & $54.2 \pm 1.0^{\mathrm{E}}$ & $58.6 \pm 0.8^{\mathrm{L}}$ & $62.9 \pm 0.7^{R}$ & $9.4 \pm 1.1^{\mathrm{a}, \mathrm{b}}$ & - \\
\hline A+Ethyl hexanoate & & $52.4 \pm 3.2^{\mathrm{E}}$ & $58.1 \pm 1.1^{\mathrm{L}}$ & $62.7 \pm 0.8^{R}$ & $9.6 \pm 1.8^{a}$ & - \\
\hline $\mathrm{A}+2-$ Hexanone ${ }^{\mathrm{C} 1}$ & & $52.6 \pm 0.2^{\mathrm{E}}$ & $57.8 \pm 0.4^{\mathrm{L}}$ & $62.5 \pm 0.4^{R}$ & $4.5 \pm 0.4^{e}$ & - \\
\hline $\mathrm{A}+2-$ Hexanone ${ }^{\mathrm{C} 2}$ & & $50.2 \pm 3.2^{\mathrm{F}}$ & $57.6 \pm 0.5^{\mathrm{L}}$ & $62.1 \pm 0.5^{R}$ & $4.7 \pm 0.6^{\mathrm{e}}$ & - \\
\hline $\mathrm{C}$ & \multirow{4}{*}{ NA } & $54.0 \pm 0.6^{\mathrm{E}}$ & $58.2 \pm 0.2^{\mathrm{L}}$ & $62.6 \pm 0.9^{R}$ & $9.0 \pm 0.4^{c, d}$ & - \\
\hline C+Ethyl hexanoate & & $53.9 \pm 0.8^{\mathrm{E}}$ & $57.8 \pm 0.6^{\mathrm{L}}$ & $62.6 \pm 0.8^{R}$ & $7.9+1.0^{b, c}$ & - \\
\hline $\mathrm{C}+2-$ Hexanone ${ }^{\mathrm{C} 1}$ & & $52.7 \pm 0.5^{\mathrm{E}}$ & $57.4 \pm 0.3^{L}$ & $63.3 \pm 0.8^{R}$ & $9.1 \pm 0.5^{b, c}$ & - \\
\hline $\mathrm{C}+2$-Hexanone ${ }^{\mathrm{C} 2}$ & & $53.5 \pm 0.8^{\mathrm{E}}$ & $57.3 \pm 0.5^{\mathrm{L}}$ & $62.8 \pm 1.6^{R}$ & $10.4 \pm 0.5^{\mathrm{a}}$ & - \\
\hline$A$ & \multirow{4}{*}{65} & $67.0 \pm 2.2^{B}$ & $69.9 \pm 1.0^{J}$ & $71.9 \pm 0.2^{Q}$ & $0.3 \pm 0.1^{\mathrm{g}}$ & $2.9 \pm 0.9^{\mathrm{ff}}$ \\
\hline A+Ethyl hexanoate & & $66.6 \pm 1.0^{\mathrm{B}}$ & $69.6 \pm 0.5^{J}$ & $71.1 \pm 0.9^{Q}$ & $0.3 \pm 0.0^{g}$ & $3.3 \pm 0.3^{\mathrm{ff}}$ \\
\hline $\mathrm{A}+2-$ Hexanone $\mathrm{C}^{\mathrm{C}}$ & & $65.3 \pm 1.2^{B, C}$ & $68.3 \pm 0.6^{\mathrm{J}, \mathrm{K}}$ & $71.4 \pm 1.3^{Q}$ & $0.4 \pm 0.1^{\mathrm{g}}$ & $8.5 \pm 2.3^{\mathrm{ee}}$ \\
\hline $\mathrm{A}+2-$ Hexanone ${ }^{\mathrm{C} 2}$ & & ND & ND & ND & $0.0 \pm 0.0^{\mathrm{g}}$ & $0.0 \pm 0.0^{\mathrm{ff}}$ \\
\hline$A$ & \multirow{4}{*}{85} & ND & ND & ND & $0.0 \pm 0.0^{g}$ & $0.0 \pm 0.0^{\mathrm{ff}}$ \\
\hline A+Ethyl hexanoate & & ND & ND & ND & $0.0 \pm 0.0^{g}$ & $0.0 \pm 0.0^{\mathrm{ff}}$ \\
\hline $\mathrm{A}+2-$ Hexanone ${ }^{\mathrm{C} 1}$ & & ND & ND & ND & $0.0 \pm 0.0^{\mathrm{g}}$ & $0.0 \pm 0.0^{\mathrm{ff}}$ \\
\hline $\mathrm{A}+2-$ Hexanone $^{\mathrm{C2}}$ & & ND & ND & ND & $0.0 \pm 0.0^{\mathrm{g}}$ & $0.0 \pm 0.0^{\mathrm{ff}}$ \\
\hline C & \multirow{4}{*}{65} & $64.8 \pm 1.5^{\mathrm{B}, \mathrm{C}, \mathrm{D}}$ & $73.0 \pm 1.4^{1}$ & $86.0 \pm 4.8^{\circ}$ & $3.2 \pm 0.5^{\mathrm{e}, \mathrm{f}}$ & $36.0 \pm 5.8^{\mathrm{bb}}$ \\
\hline C+Ethyl hexanoate & & $62.2 \pm 0.5^{\mathrm{D}}$ & $66.0 \pm 0.9^{\mathrm{K}}$ & $71.6 \pm 1.4^{Q}$ & $3.2 \pm 0.3^{e, f}$ & $40.5 \pm 3.7^{\mathrm{aa}, \mathrm{bb}}$ \\
\hline $\mathrm{C}+2-$ Hexanone $\mathrm{C}^{\mathrm{C}}$ & & $64.3 \pm 2.5^{C, D}$ & $71.0 \pm 4.0^{\mathrm{J}, \mathrm{K}}$ & $82.2 \pm 5.4^{p}$ & $3.4 \pm 0.4^{\mathrm{e}, \mathrm{f}}$ & $36.2 \pm 4.6^{\mathrm{bb}}$ \\
\hline $\mathrm{C}+2-$ Hexanone $^{\mathrm{C} 2}$ & & $65.0 \pm 1.4^{\mathrm{B}, \mathrm{C}, \mathrm{D}}$ & $73.6 \pm 2.8^{1}$ & $86.8 \pm 5.4^{\circ}$ & $4.5 \pm 1.2^{c}$ & $50.5 \pm 4.5^{\text {aa }}$ \\
\hline C & \multirow{4}{*}{85} & $43.4 \pm 2.6^{G}$ & $53.3 \pm 0.9^{\mathrm{M}}$ & $60.9 \pm 0.7^{R}$ & $2.3 \pm 0.6^{f, g}$ & $25.8 \pm 6.6^{c c}$ \\
\hline C+Ethyl hexanoate & & $74.5 \pm 4.5^{\mathrm{A}}$ & $81.2 \pm 4.4^{H}$ & $92.2 \pm 2.0^{\mathrm{N}}$ & $1.0 \pm 0.3^{\mathrm{f}, \mathrm{g}}$ & $12.8 \pm 3.5^{\mathrm{dd}}$ \\
\hline $\mathrm{C}+2-$ Hexanone ${ }^{\mathrm{C} 1}$ & & $42.5 \pm 0.9^{G}$ & $52.8 \pm 2.8^{\mathrm{M}}$ & $60.1 \pm 3.8^{R}$ & $2.1 \pm 0.6^{f, g}$ & $22.1 \pm 5.9^{c c}$ \\
\hline $\mathrm{C}+2$-Hexanone $\mathrm{C2}^{\mathrm{C}}$ & & $73.9 \pm 3.8^{\mathrm{A}}$ & $79.8 \pm 2.7^{\mathrm{H}}$ & $85.7 \pm 3.8^{\circ}$ & $1.4 \pm 0.6^{f, g}$ & $13.5 \pm 5.5^{\mathrm{dd}}$ \\
\hline
\end{tabular}

*Percentage ratio of melting enthalpy of cooked sample versus melting enthalpy native starch of each recipe and flavour addition. Significance tests were performed on each parameter separately. Different labels in superscript indicate significant difference $(P<0.001)$ at $95 \%$ confidence interval by Fisher's LSD test.

NA: Not applicable (Native starch)

ND: Not Determined 


\subsubsection{DSC measurement of heat-treated samples}

The freshly prepared samples were frozen and subjected to freeze-drying to prevent retrogradation. After freeze-drying, the samples were ground and subjected to DSC analysis, the results showed that there was no retrogradation of the samples. The fully gelatinised samples remained amorphous (thus glassy in the dry state and room temperature) and the partially gelatinised samples kept the same degree of crystallinity as before freeze-drying.

In addition to the checking the absence of retrogradation in excess water, the DSC analysis of freeze-dried samples were used for $T_{g}$ analysis. $T_{g}$ value was taken from midpoint heat capacity of the second heating scan to avoid effect of thermal history Figure 4-4. Figure 4-4 (a)-(d) shows that the $T_{g}$ of freeze-dried samples were expected to be very high $\left(>140{ }^{\circ} \mathrm{C}\right)$ since in could not be visible in the study conditions. Therefore with a view to facilitating ageing in sub-Tg conditions, the samples were stored at 58 and $75 \% \mathrm{RH}$ in order to reduce the $T_{g}$, which allowed to choose: time, temperature, and conditions for the storage study Figure 4-4 (e)-(h). The results of $\mathrm{T}_{\mathrm{g}}$ at 58 and $75 \% \mathrm{RH}$ versus moisture content are represented in Figure 4-5 and the details are showed in Appendix 2: Table A-2. The glass transition pattern was less marked before ageing, the change in $\mathrm{Cp}$ being more diffuse (Chung \& Lim, 2003a). However the $T_{g}$ was observed in the analysis temperature range when the sample uptook water. The results of the whole set showed the same pattern of $T_{g}$ expectingly decreasing upon increasing of humidity. At $58 \% \mathrm{RH}$, the moisture content varied between 7.6 and $11.2 \%$, and the samples' $\mathrm{T}_{\mathrm{g}}$ were comprised between 76 and $86{ }^{\circ} \mathrm{C}$, except $\mathrm{C} 65 \mathrm{EH}\left(67^{\circ} \mathrm{C}\right)$. At $75 \% \mathrm{RH}$, the $\mathrm{T}_{\mathrm{g}}$ of samples were approximately $53-67^{\circ} \mathrm{C}$ and \%moisture varied from 9.7-17.6\%. Expectedly, $T_{g}$ values decreased with increasing water content. The samples were stored in air tight vials therefore the variation in moisture contents should be due to samples properties and structures.

\section{Box 3: 4.1.3 Section highlight}

- The $T_{g}$ decreased upon increasing of moisture content.

- $\mathrm{Tg}$ of samples at $58 \% \mathrm{RH}$ ranged between $67-86^{\circ} \mathrm{C}$.

- $\mathrm{Tg}$ of samples at $75 \% \mathrm{RH}$ ranged between $53-67^{\circ} \mathrm{C}$. 


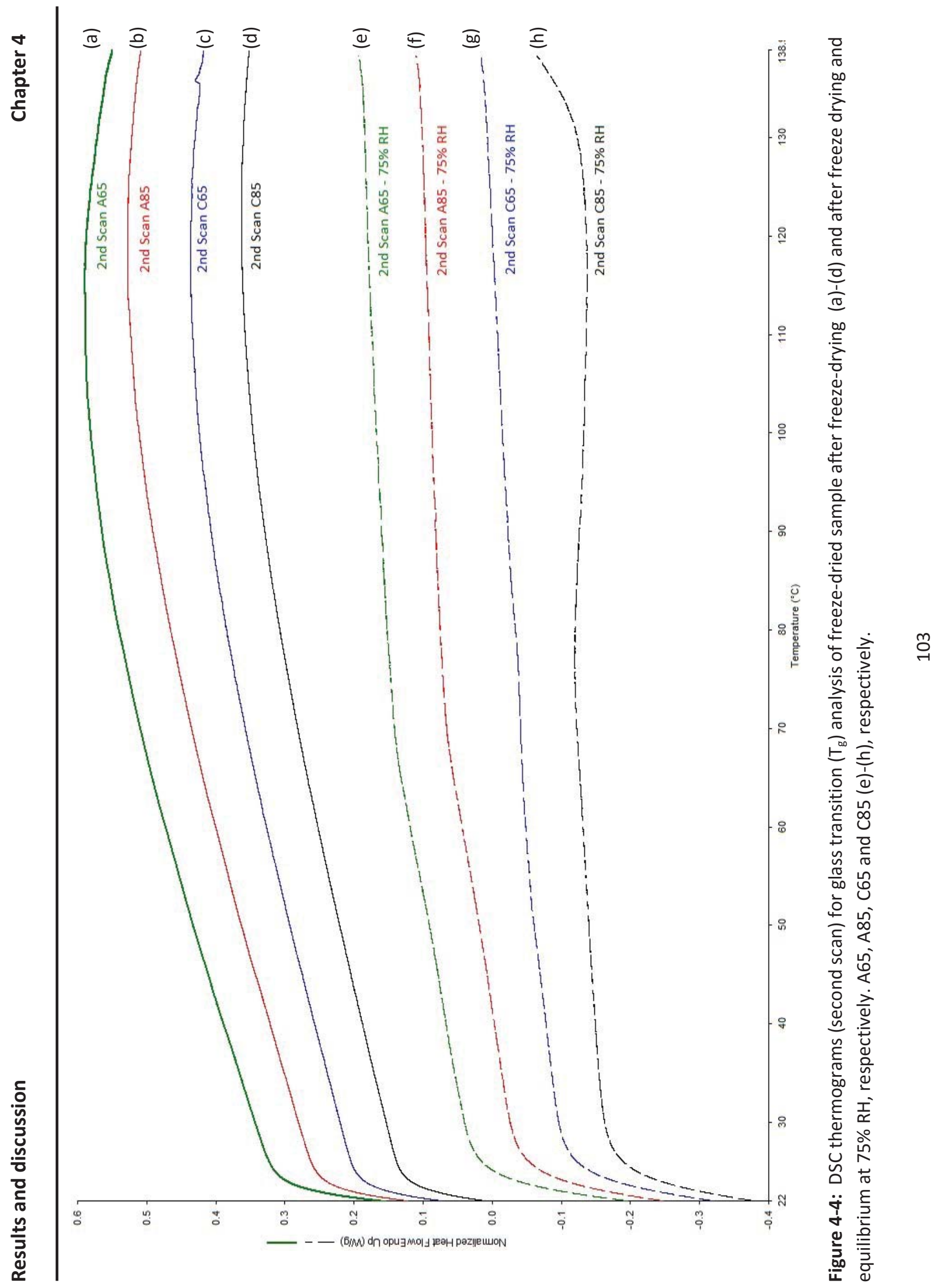




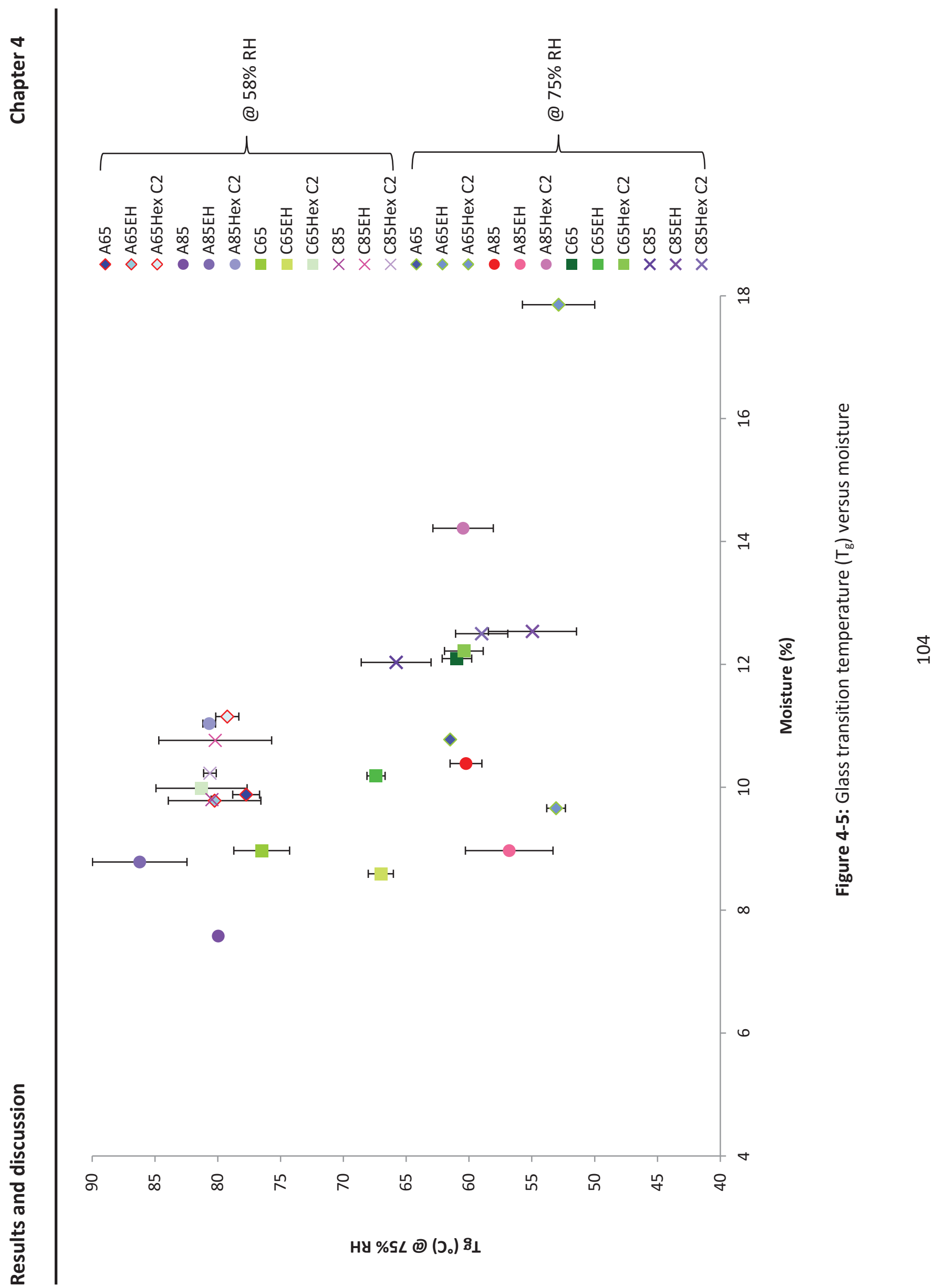




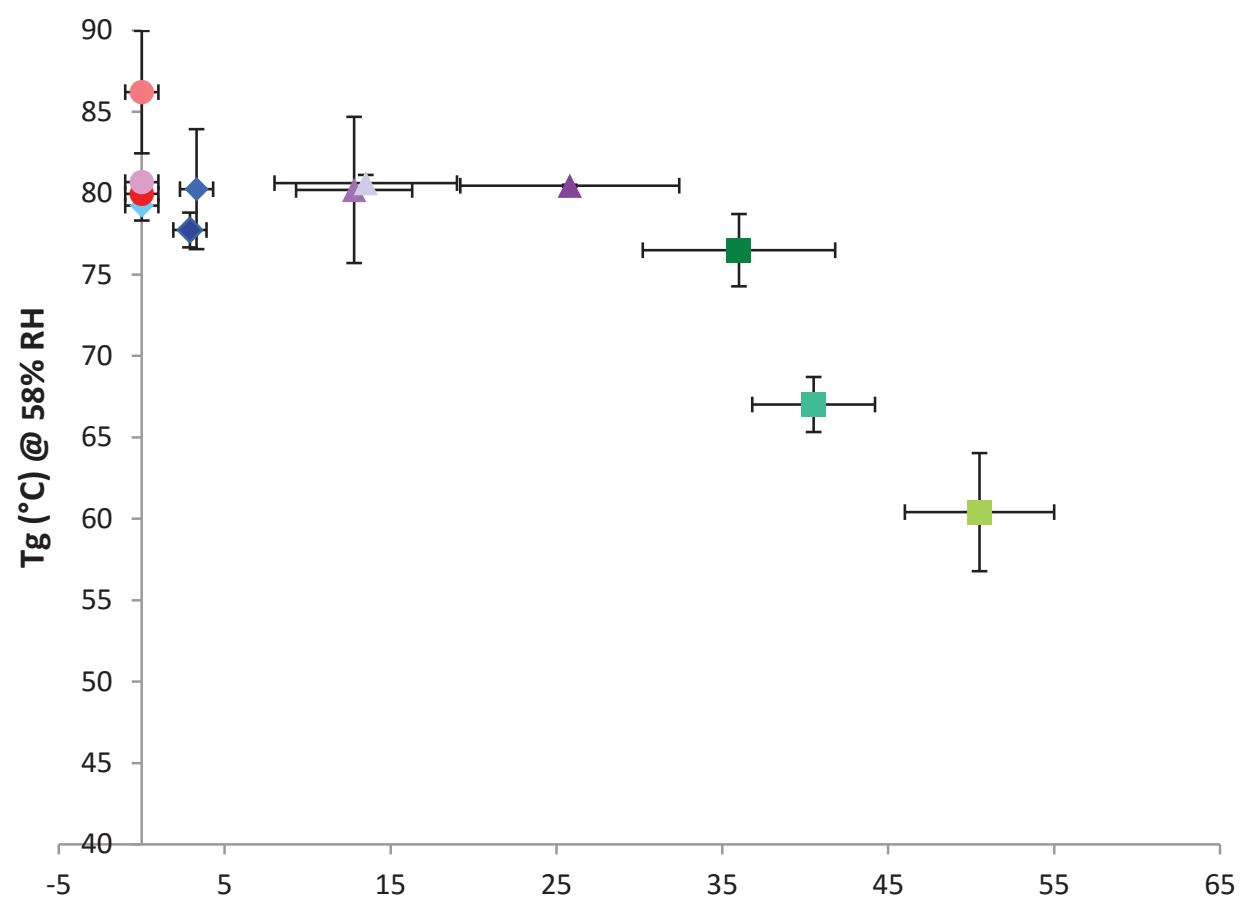

(a)

- A65

A A65EH

$\checkmark \mathrm{A} 65 \mathrm{Hex} \mathrm{C2}$

A85

A85EH

- A85Hex C2

- 65

- $655 \mathrm{EH}$

- C65Hex C2

$\triangle \mathrm{C} 85$

$\triangle \mathrm{C} 85 \mathrm{EH}$

$\triangle \mathrm{C} 85 \mathrm{Hex} \mathrm{C2}$

Residual native starch (\%)

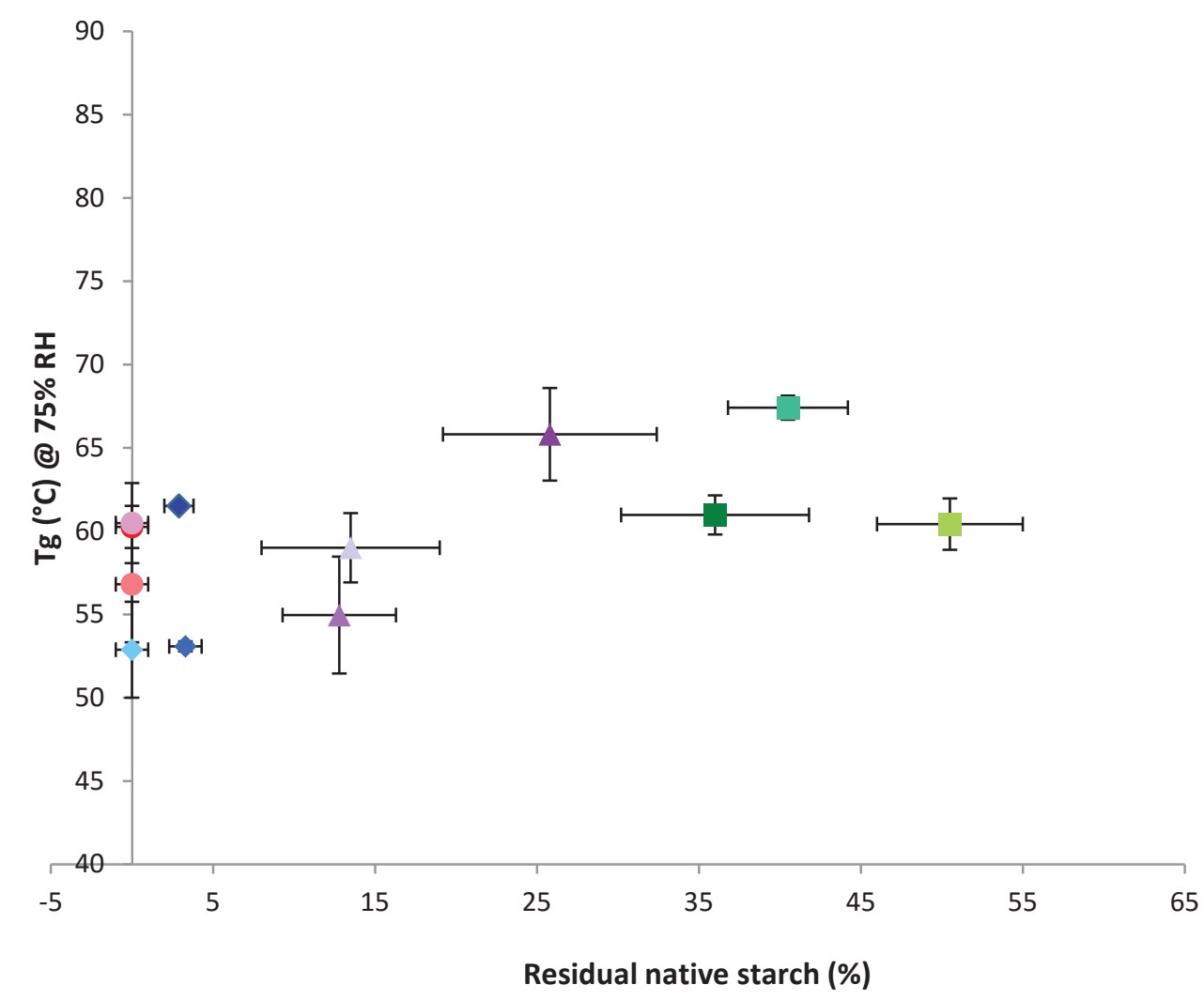

(b)

- A65

$\checkmark \mathrm{A} 65 \mathrm{EH}$

$\checkmark \mathrm{A} 65 \mathrm{Hex} \mathrm{C2}$

A85

A85EH

A85Hex C2

- 665

C65EH

C65Hex C2

$\triangle \mathrm{C} 85$

$\triangle \mathrm{C} 85 \mathrm{EH}$

$\triangle \mathrm{C} 85 \mathrm{Hex} \mathrm{C2}$

65

Residual native starch (\%)

Figure 4-6: Glass transition temperature $\left(\mathrm{T}_{\mathrm{g}}\right)$ versus percent relative crystallinity at $58 \% \mathrm{RH}(\mathrm{a})$, $75 \% \mathrm{RH}(\mathrm{b})$ 
The results of glass transition temperature were plotted against \% relative crystallinity according to storage relative humidity (Figure 4-6).

Figure 4-6 represent the relationship between $T_{g}$ and \% residual native starch at $58 \%$ $\mathrm{RH}$ and $75 \% \mathrm{RH}$, respectively. A65 and $\mathrm{A} 85$ samples were similar in \% residual native (0-3\%). At $58 \% \mathrm{RH}$, it was found that $\mathrm{T}_{\mathrm{g}}$ of $\mathrm{A} 65$ samples were $78-80{ }^{\circ} \mathrm{C}$ while the $T_{g}$ of $A 85$ s samples were slightly higher $\left(80-86^{\circ} \mathrm{C}\right)$ than A65 sample though they exhibited no residual native. Samples C65 were very different from other samples in their content of residual native starch. The increasing \% native starch/crystallinity is accompanied by a declining $T_{\mathrm{g}}$ which is contrary to literature data (Zeleznak \& Hoseney, 1987), this is possible to be due to the change in moisture contents. However, at $58 \% \mathrm{RH}$ the hydration change was not as wide as at $75 \% \mathrm{RH}$ for which the evolution is in agreement with literature (Zeleznak \& Hoseney, 1987). The contribution of flavour may be questioned. $\mathrm{C} 85 \mathrm{EH}$ and $\mathrm{C} 85 \mathrm{HexC} 2$ were similar in both residual native starch content and $\mathrm{T}_{\mathrm{g}}$. Comparing C85 with $\mathrm{C} 85 \mathrm{EH}$ and $\mathrm{C} 85 \mathrm{HexC2}$, they were significantly different $(\sim 13 \%)$ in residual native starch content but possessed the same $\mathrm{T}_{\mathrm{g}}\left(80^{\circ} \mathrm{C}\right)$. This could possible due to experimental error since their \% residual native starch possessed large standard deviation.

Once the relative humidity was increased from $58 \%$ to $75 \%$, the $\mathrm{T}_{\mathrm{g}}$ decreased of approximately $10-20{ }^{\circ} \mathrm{C}$. At $75 \% \mathrm{RH}, \mathrm{T}_{\mathrm{g}}$ of $\mathrm{A} 65$ and $\mathrm{A} 65 \mathrm{HexC2}$ were similar, which might be due to their similarity in \% residual native starch. It is interesting that the effect of crystallinity on $\mathrm{T}_{\mathrm{g}}$ of $\mathrm{A} 65$ samples were very similar for both \% $\mathrm{RH}$. It is speculated that the difference was due to type of flavour and its interaction. The result of samples A85 at 75\% $\mathrm{RH}$ suggested their $\mathrm{T}_{\mathrm{g}}$ were not different $\left(57-60.5^{\circ} \mathrm{C}\right)$ which is in agreement with their \% residual native starch (0\%). $\mathrm{C} 65 \mathrm{Hex} \mathrm{C} 2$ contained $51 \%$ residual native starch was found to have the same $T_{\mathrm{g}}\left(\sim 60{ }^{\circ} \mathrm{C}\right)$ as of $\mathrm{C} 65$ (36\% residual native starch). C65 samples exhibited a large variation in their \% residual native starch which might be the reason why the $\mathrm{T}_{\mathrm{g}}$ of $\mathrm{C} 65$, $\mathrm{C} 65 \mathrm{EH}$ and $\mathrm{C} 65 \mathrm{HexC2}$ varied among the $\mathrm{C} 65$ set.

C85EH and C85Hex C2 contained approximately 13\% residual native starch, they were found to have $4{ }^{\circ} \mathrm{C}$ different in $\mathrm{T}_{\mathrm{g}}\left(55\right.$ and $59^{\circ} \mathrm{C}$, respectively) while $\mathrm{T}_{\mathrm{g}}$ of $\mathrm{C} 65$ was greater than the other two's due to its greater in \% residual native starch. Generally, $T_{g}$ depends on both moisture content and \% crystallinity. In this study, it can be seen clearly that there were such variation in moisture content among samples with similar residual native starch, that the $T_{g}$ results varied due to the moisture content in spite of a constant residual native 
starch content. The overall results at $58 \% \mathrm{RH}$ suggested that $\mathrm{T}_{\mathrm{g}}$ decreased as \% residual native increased. The overall results at $75 \% \mathrm{RH}$ seemed to contrast to those at $58 \%$ since the $\mathrm{T}_{\mathrm{g}}$ seemed to increase when \% residual native increased. However, the $\mathrm{T}_{\mathrm{g}}$ of each sample clustered around $52-67{ }^{\circ} \mathrm{C}$. Such a different behaviour between $58 \%$ and $75 \% \mathrm{RH}$ may be related to other structural differences (e.g. granular structure for example) rather than \% of native starch, existing within the samples set (from A 65 to C85) that could be dominating at $58 \% \mathrm{RH}$. Such differences, if any, will be investigated in the next parts.

\subsubsection{Pasting profile}

The prepared samples were freeze-dried and analysed by RVA and compared with both commercial native and pre-gelatinised starches. Figure 4-7a-b represents the hydration effect on RVA pasting profile. The pasting properties are presented in Table 4-4. The data (peak viscosity, trough, breakdown, final viscosity, setback, pasting time and pasting temperature) together with sample formulae, treatment temperature and types of flavour were subjected to an ANOVA. Native and pre-gelatinised samples exhibited different pasting behaviour, actually representing extreme pasting profiles. Indeed, native starch showed the highest peak, trough, breakdown viscosities, and on the opposite, pre-gelatinised starch exhibited the lowest viscosity values. The very low final viscosity of the pre-gelatinised starch suggested that it was unable to form a gel, pointing to the severity of industrial treatment which may have not only gelatinised the sample but possibly also partially hydrolysed some macromolecules preventing them from reorganising/retrograding upon cooling. The viscosities of A85 were the highest among prepared samples; they were comparable for A65 and C65 and higher than for C85. In the literature, peak viscosity is attributed to amylopectin content, crystallinity and swelling (Lan, et al., 2008), breakdown is related to intragranular bonds breakage and granule stability (Zavareze \& Dias, 2011) and final viscosity to reorganisation ability.

Pasting temperatures of heat-treated samples with/without flavour were higher than for both native and commercial pre-gelatinised starch. Pasting temperatures of sample with flavour were higher than both native and pre-gelatinised starches. Such an increase of pasting temperature upon thermal treatment has been associated with the formation of a more organised structure (Tester et al., 1998) below gelatinisation temperature through annealing or so called "heat-moisture treatment" (Biliaderis, 2009; Zavareze \& Dias, 2011). 
The effects of these two treatments are controversial depending on the type of starch and study conditions (Jacobs, Eerlingen, \& Delcour, 1996; Zavareze \& Dias, 2011).

Sample A85 showed a high peak viscosity which could result from an incomplete swelling during the initial heating treatment in spite of the DSC observed lack of crystallinity. This is aligned with phenomenological aspects of gelatinisation in which melting endotherm is observed by DSC around $55-65{ }^{\circ} \mathrm{C}$ while swelling can continue to develop up to $100{ }^{\circ} \mathrm{C}$ (Eliasson \& Larsson, 1993). In the A samples, whether heated at 85 or $65{ }^{\circ} \mathrm{C}$, the crystals were melted (Table 4.3) but the granules had not fully swollen during their preparation treatment, thus could keep on swelling during the heating of RVA analysis. In A65, the peak viscosity is lower than in A85, as if the granules had a lower swelling capacity such as the one caused by annealing treatment on fermented cassava starch (Zavareze \& Dias, 2011). It demonstrated that annealing caused lower peak, hold, breakdown viscosities while pasting temperature was increased (Gomes, Mendes da Silva, \& Ricardo, 2005). Annealing has been described (Tester et al., 1998) as reorganising the granular structure towards an increased granular stability which could cause the observed lower peak and breakdown viscosities of A65. C85 sample had the highest residual crystalline starch content (Table 4-3) but showed the lowest viscosities possibly as a result of limited swelling due to reinforced granule structure.

In the temperature and hydration ranges of the samples preparation, the water contents used in samples preparation could be considered in the range of gelatinisation (in terms of crystal melting) but they were also close to the boundary of annealing and heatmoisture treatment as defined by Biliaderis (2009) as previously seen through the lower swelling in the prepared samples. Indeed peak viscosity values were always lower than for native starch due to lower crystallinity and lower ability to swell, however they were higher than pre-gelatinised starch values.

Heat-moisture treatment (below gelatinisation stage) disrupts the crystalline structure and dissociates the double helical structure in the amorphous regions, these changes are followed by the rearrangement of the disrupted crystals (Gunaratne \& Hoover, 2002; Zavareze \& Dias, 2011). Wheat starches that underwent heat-moisture and annealing treatments were found to exhibit a reduced swelling power (Zavareze \& Dias, 2011). However, the two hydrothermal treatments had opposite effect on pasting profiles. Wheat starch was found to exhibit increasing pasting temperature but decreasing peak viscosity, 
final viscosity and breakdown after heat-moisture treatment (Q. Sun, et al., 2014; Tester \& Debon, 2000; Zavareze \& Dias, 2011). This is in agreement with the occurrences found in C samples.

The statistical analysis of RVA results versus flavour addition effect found that ethyl hexanoate containing samples had significantly higher viscosities than both the no flavour added ones and 2-hexanone containing ones which exhibited comparable pasting profile parameters (Table 4-4 \& Figure 4-7a-b). This suggests that the type of interactions set between 2-hexanone and starch did not significantly affect the starch pasting behaviour similarly to the results obtained by Blazek, et al. (2011) with non-complexing fatty acids and starch. Although, no flavour-starch complex were detected by DSC in the prepared samples, it is likely that the structure (such as complex but not exclusively) formed by the interaction between starch and ethyl hexanoate affected the starch pasting profile. Blazek et al. (2011) suggested that complexing agents could promote the formation of single amylose helices over double helical structures, causing amylose to form globular aggregates rather than networks such as those observed in pastes with no added lipid or in the presence of noncomplexing lipids. Tang \& Copeland (2007) concluded that the inclusion of lipids in starch pastes decreased the holding viscosity, whereas the final viscosity was increased. In the present study, all pasting parameters were found to increase with the addition of ethyl hexanoate. If the interactions were comparable with starch-lipid complex ones, this discrepancy could possibly be due to experimental conditions: sample preparation, type and concentration of complexing agents.

At limiting hydration, starch was still able to complete gelatinisation by mean of birefringence loss and structure disruption thanks to the extent of the thermal treatment $\left(85^{\circ} \mathrm{C}\right)$ which could disassociate helix-coil of amylopectin double helices (Waigh et al., 2000). Indeed continuous heating allowed crystallites to undergo a conventional melting transition. Although there were insufficient water (compared to the usual excess hydration), the thermal energy was sufficient to both break the inter-mesogen hydrogen bonds and increase the mobility of the amylopectin double helices side-by-side (Waigh, Kato, et al., 2000). However, low water content limited granule swelling capacity. 

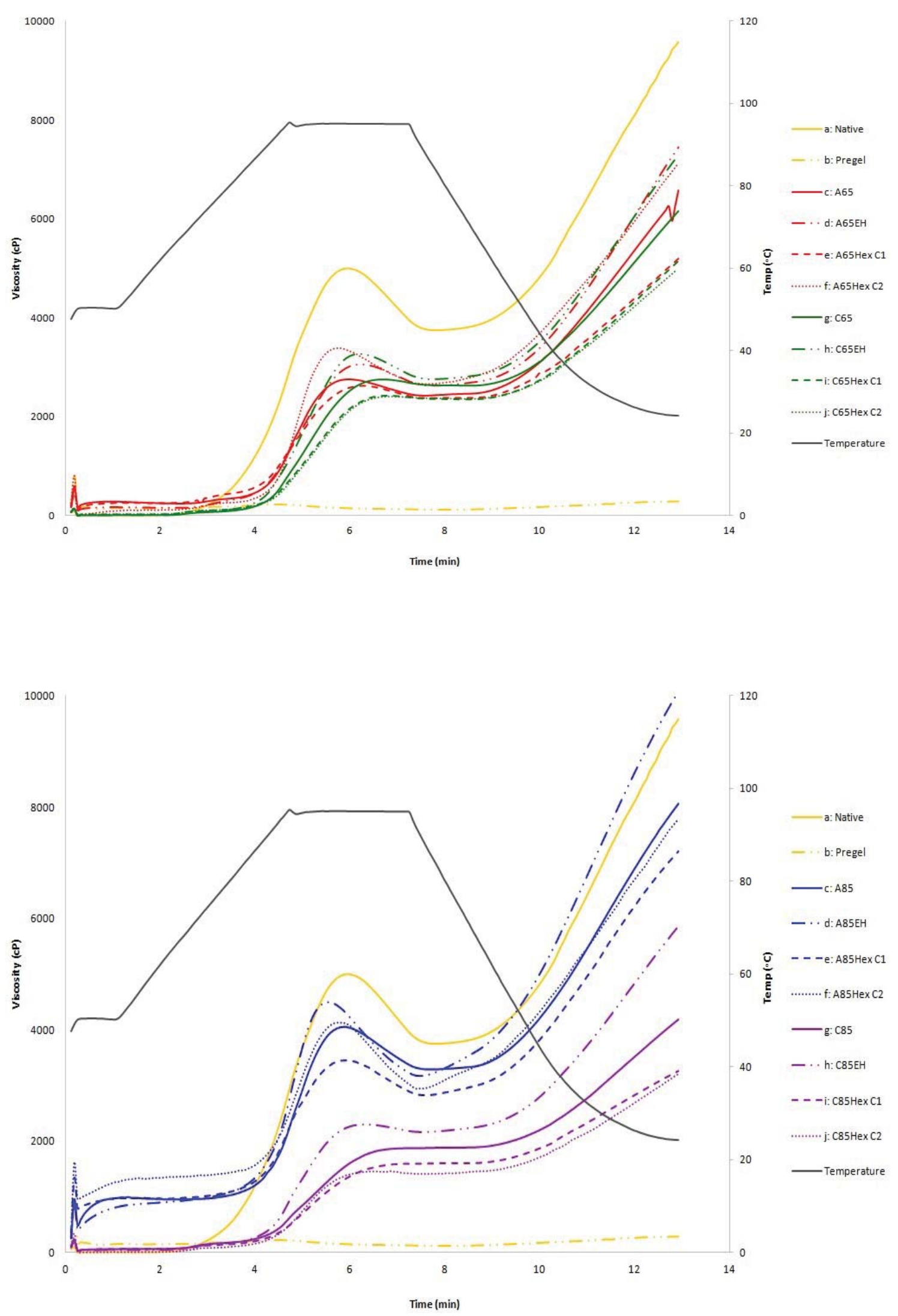

Figure 4-7a-b: RVA pasting profiles of freeze-dried starch in comparison on flavour addition and treatment temperature. 
The result of RVA pasting profile, \% residual native starch and flavour addition were subjected to principal component analysis (PCA) and the obtained results are shown in Figure 4-8. The results clearly showed that native and pre-gelatinised starches are extremely different from samples $A$ and $C$. The distribution and clustering of the samples in PCA diagram emphasised that each sample is different. The distribution can be clearly associated with an effect of viscosity and \% residual native starch. A samples are mostly found in due to high viscosities values while samples C are mostly in quadrant I and II due to their high \% residual native starch and lower viscosities. Flavour addition seemed to have less influence on sample distribution compared to pasting parameters since it is the only factor in quadrant III.

\section{Box 4: 4.1.4 Section highlight}

- Annealing affected pasting properties RVA profile by increasing peak viscosity (A85) compared to other samples.

- Heat-moisture treatment affected RVA profile by reducing peak viscosity (C85) compared to other samples.

- Flavour addition had no significant effect on RVA profile. 


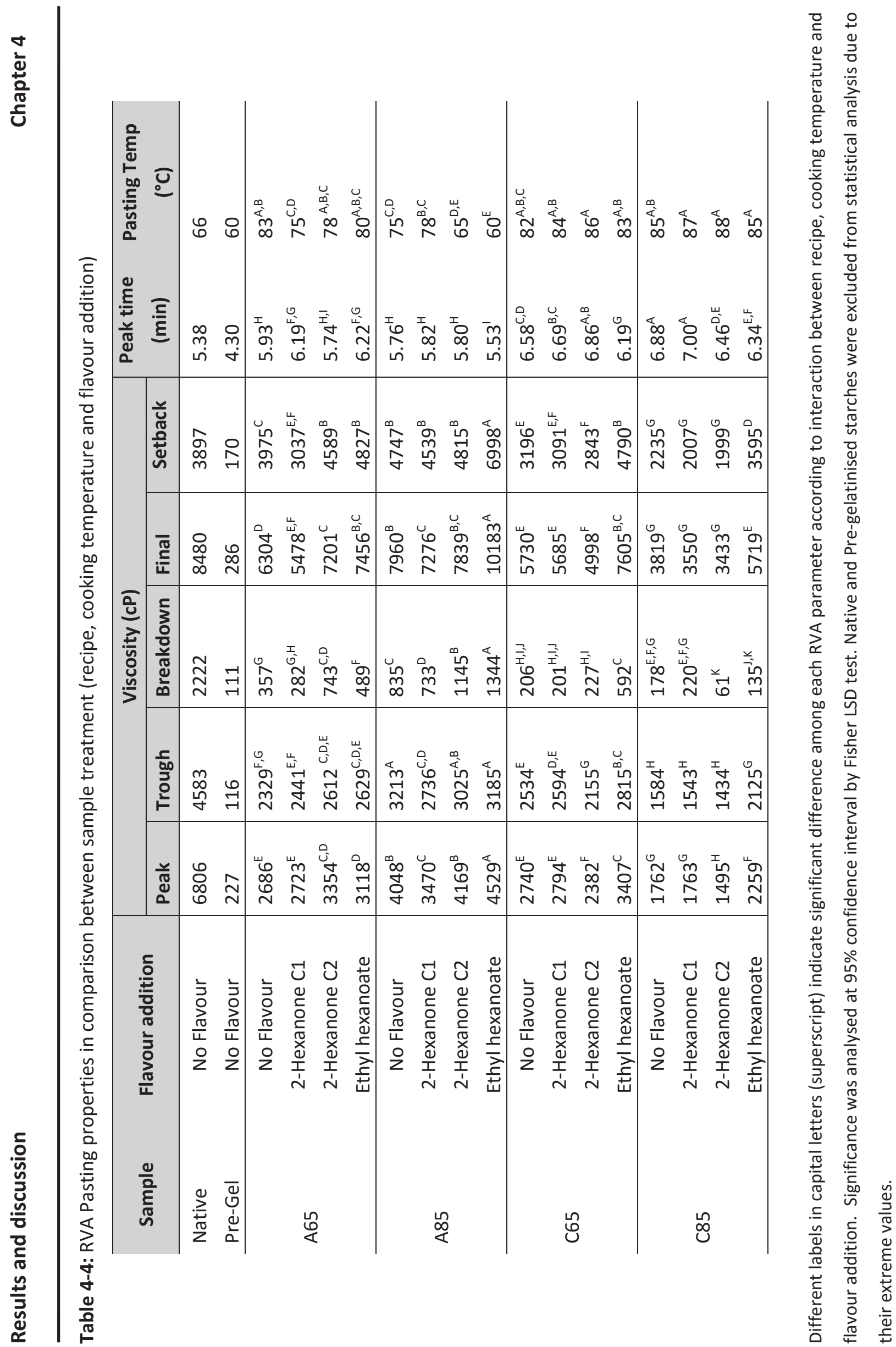




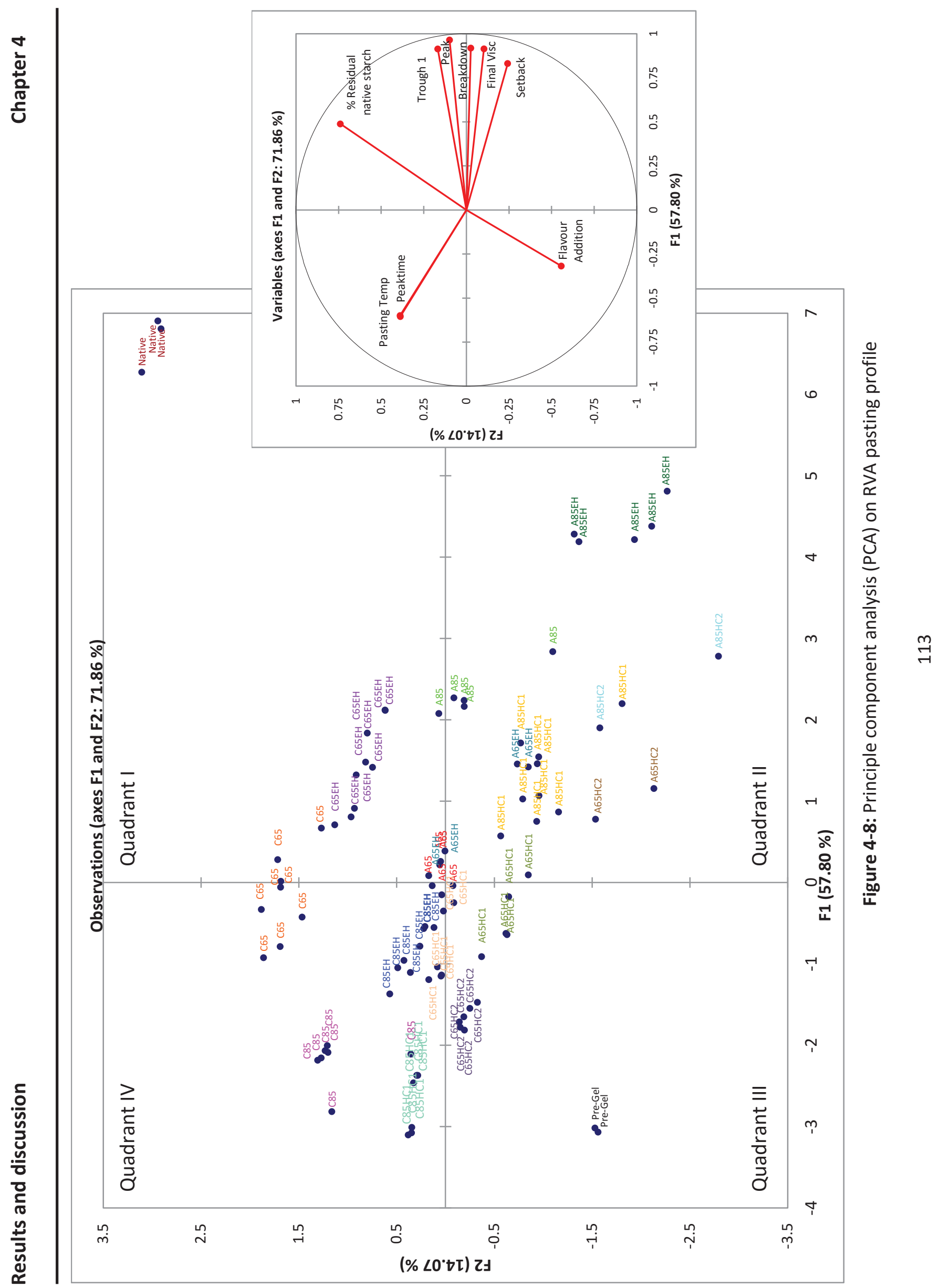




\subsubsection{Structural analysis}

Structural analysis was conducted to fulfil the information of changes upon hydrothermal treatments. It can be considered at 2 levels: granular and sub-granular. The first level was studied by mean of granule size measurement. The second one was investigated through fine structure analysis by $\mathrm{X}$-ray diffraction and scattering techniques.

\subsubsection{Granule study size}

The results of granule size distribution by \% volume are shown in Figure 4-9 (comparing versus sample preparation) and Figure 4-10 (comparing versus flavour addition). According to Figure 4-9 and 4-10, as expected from literature (Kim \& Huber, 2008) native starch shows 2 populations which are $<10 \mu \mathrm{m}$ (A type) and between 10-100 $\mu \mathrm{m}$ (B type). Commercial pre-gelatinised starch was also found to be distributed within two populations with a greater distribution in B type, and a larger average diameter within this population, as a result of granule swelling upon gelatinisation industrial processes.

Considering pattern of granule size distribution, most samples except A65, $\mathrm{A} 65 \mathrm{EH}$ and $\mathrm{A} 65 \mathrm{Hex} \mathrm{C} 1$ were bimodal. It is interesting that A65, A65EH and A65Hex C1 possessed identical distribution while A65Hex C2 was different. It is possible that the temperature and amount of water facilitated a greater swelling in $\mathrm{A} 65, \mathrm{~A} 65 \mathrm{EH}$ and $\mathrm{A} 65 \mathrm{Hex}$ C1 causing a loss of the bimodal features and a shift of the sizes to the larger population. In case of $\mathrm{A} 65 \mathrm{Hex} \mathrm{C2}$, the higher amount of 2-hexanone possibly retarded swelling. Although it is still unclear whether 2-hexanone is able to form inclusion-complex with starch or not, the higher concentration of this ternary compound might be speculated to limit starch swelling in the same manner as for amylose-lipid complex that inhibit swelling (Tester \& Morrison, 1990). In general, all studied samples possessed a larger granule size than native and pregelatinised starches which probably partly bursted due to hydrothermal treatments. Both native and pre-gelatinised starches were distributed into different groups as native starch granules did not yet swell to their maximum potential while pre-gelatinised starch exhibited the diameter of bursted granule after pre-gelatinisation treatment.

It seems like there is no influence of flavour addition for the same level of hydrothermal treatment applied (Figure 4-9). However, Figure 4-10 distinguishingly shows that granule size alteration was driven by level of heat and hydration. It was found that granule diameters of A65 samples were larger than others in every type of flavour addition. The effect of flavour at different heat-hydration level seems to have no general pattern. 
The detail of particle size parameters are shown in Table 4-5. The percentiles of granule size distribution were calculated based on \%volume. The mean of particle size was derived from those 3 percentiles. In this study, the results are based on volume distribution rather than surface distribution since the samples were pre-treated and they do not have the same properties as native starch.

According to Table 4-5, the overall results suggested that samples A65 series are the largest in granule size followed by A85, C65 and C85 samples. The volume weighted mean $D[4,3]$ was represented as bar chart with significance test in Figure 4-11. It was found that granule diameters are significantly different within the same recipe but different flavour treatment except for A85 and C65. The overall results suggested that A65 group is largest in size while C65 and C85 are not different. Regarding influence of flavour addition, ethyl hexanoate seemed to increase the size of granule or swelling when the samples were heated at $65^{\circ} \mathrm{C}$. The influence of ethyl hexanoate was in reverse when the heating temperature was raised to $85^{\circ} \mathrm{C}$. This is possibly due to different rate of reaction at 65 and $85^{\circ} \mathrm{C}$.

In case of samples with 2-hexanone, it was found that the granule diameters were smaller than without flavour but there was no significant influence between flavour amount at high hydration level. At low hydration level, the influence was specific to each sample. 2-Hexanone was unable to drive any change on sample C65 at low amount but increased the granule size when at the highest amount. This is possible that $\mathrm{C} 65 \mathrm{Hex} \mathrm{C} 2$ had lower reaction rate, increase possibility of water to get into the granule therefore the granules were more swollen. Regarding C85 with 2-hexanone, the result was totally opposite to $\mathrm{C} 65$ with 2-hexanone. This can be suggested that it was due to high heating temperature.

There is a possible relationship between RVA pasting profile and granule size. It is known that the peak viscosity in RVA pasting profiles are generally influenced by starch architecture features (Alvarado, Grosmaire, Dufour, Toro, Sánchez, Calle, et al., 2013; J. Huang, Chen, Xu, Li, Liu, Yang, et al., 2014). The volume weighted mean and RVA peak viscosity were represented as coordination plot in Figure 4-12. The granules diameters of native starch were smaller than the samples after treatment but it had the highest pasting viscosity. Pre-gelatinised starch had a larger diameter compared to native starch and similar to other samples but it was unable to form gel as can be seen from the low set back 
viscosity and possibly due to an important hydrolysis of the biopolymer chains then unable to reassemble.

However, both diameter of native and pre-gelatinised are smaller than other samples. The granule diameter of native starch represented its actual size without any treatment while the diameter of pre-gelatinised reflected granule disruption by industrial process. The granule was fully swollen and broken upon industrial process therefore the average granule size was much smaller (the intact granules were not fully swollen yet) than in $\mathrm{A}$ and $\mathrm{C}$ samples.

Jenkins and Donald, (1998) used the combination of SAXS, WAXS, DSC and SANS to explain starch gelatinisation process ( $40 \%$ moisture content, heating at $120{ }^{\circ} \mathrm{C}$ ). They concluded that water firstly enters the amorphous growth rings where the swelling occurred and concentrated. Once the swelling reaches certain degree, there is a stress imposed upon the amylopectin crystallites, by virtue of the connectivity of molecules from the growth ring into semi-crystalline lamellae, to start disrupting the crystals themselves. The final loss of crystallinity and ultimate breakdown of granule only occurs quite late in the gelatinisation process.

Regarding Figure 4-12, native and pre-gelatinised starch were extremely different from the prepared samples. The figure clearly showed the relationship between granule size and viscosity. A65 samples were the largest in granule diameter but had a lower viscosity compared to A85 samples. This is due to the fact that low temperature favoured granule swelling. However, the heating temperature was not sufficient to promote the complete swelling therefore samples A85 further developed higher viscosity than sample A65. This result suggested that the higher temperature of A85 better promoted crystal melting and amylose leaching, therefore the viscosity increased greater than for A65.

The relationship between granule size and viscosity development was opposite at low hydration level. C65 and C85 samples were similar in granule size but C85 had a lower viscosity. This suggested that at low hydration, the swelling was limited due to insufficient of water and alignment of the helices (side-by-side) however there is high temperature to facilitate crystal melting (temperature compensation) (Waigh, Gidley, et al., 2000). Although the gelatinisation in $\mathrm{C}$ samples was not completed, there were changes within granules due to high temperature resulting in structural collapse as the semi-crystalline layers were melted. Amylose and amylopectin chains line-up closer upon hydration of granule. The 
chains stay closer in limiting hydration conditions than in excess water conditions, therefore it was more difficult to develop the viscosity compared to A samples.

The study of Jenkins and Donald, (1998) partially answered the question whether there is a critical level of water (and hence swelling) required in the amorphous background region for destabilisation to occur (Jenkins \& Donald, 1998). The results of RVA and granule size measurement in this study demonstrated distinct behaviours and characteristics between $\mathrm{A}$ and $\mathrm{C}$ samples. It seems that the phenomena can be used to emphasise the answer of Jenkins and Donald, (1998) that there is a critical level of water required in governing the swelling and gelatinisation.

It was postulated that under hydrothermal treatment a mild swelling of wheat starch occurs over the temperature range of $50-60{ }^{\circ} \mathrm{C}$, followed by a second extensive swelling at $80-90{ }^{\circ} \mathrm{C}$, resulting in the possible rupture and solubilisation of the granules (Malumba, et al., 2013). Isothermal heatings at 65 and $85{ }^{\circ} \mathrm{C}$ were applied to starch in this study. Each of these two temperatures fall in different swelling extents. This could be another reason to explain the different swelling behaviour between of each studied sample.

\section{Box 5: 4.1.5.1 Section highlight}

- The granules of pre-gelatinised starch were destroyed upon industrial process.

- The granules of samples had greater diameter than native granules as a result of treatment.

- At high hydration, lower temperature promoted greater swelling while higher temperature promoted higher viscosity but limited swelling. Amylose leaching is speculated to involve in swelling extent and viscosity development.

- At low hydration, there was no significant effect of temperature on granule size. 


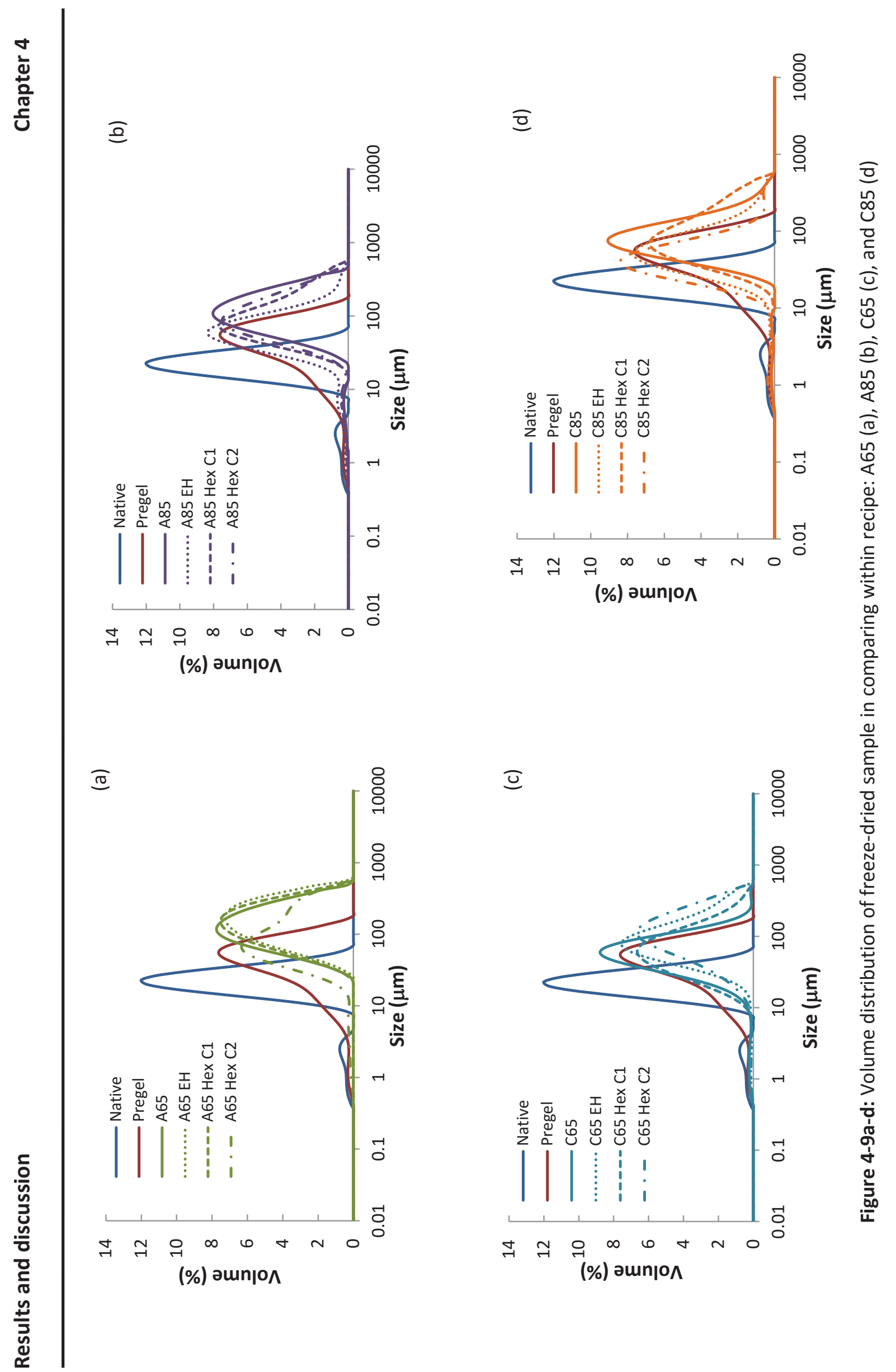




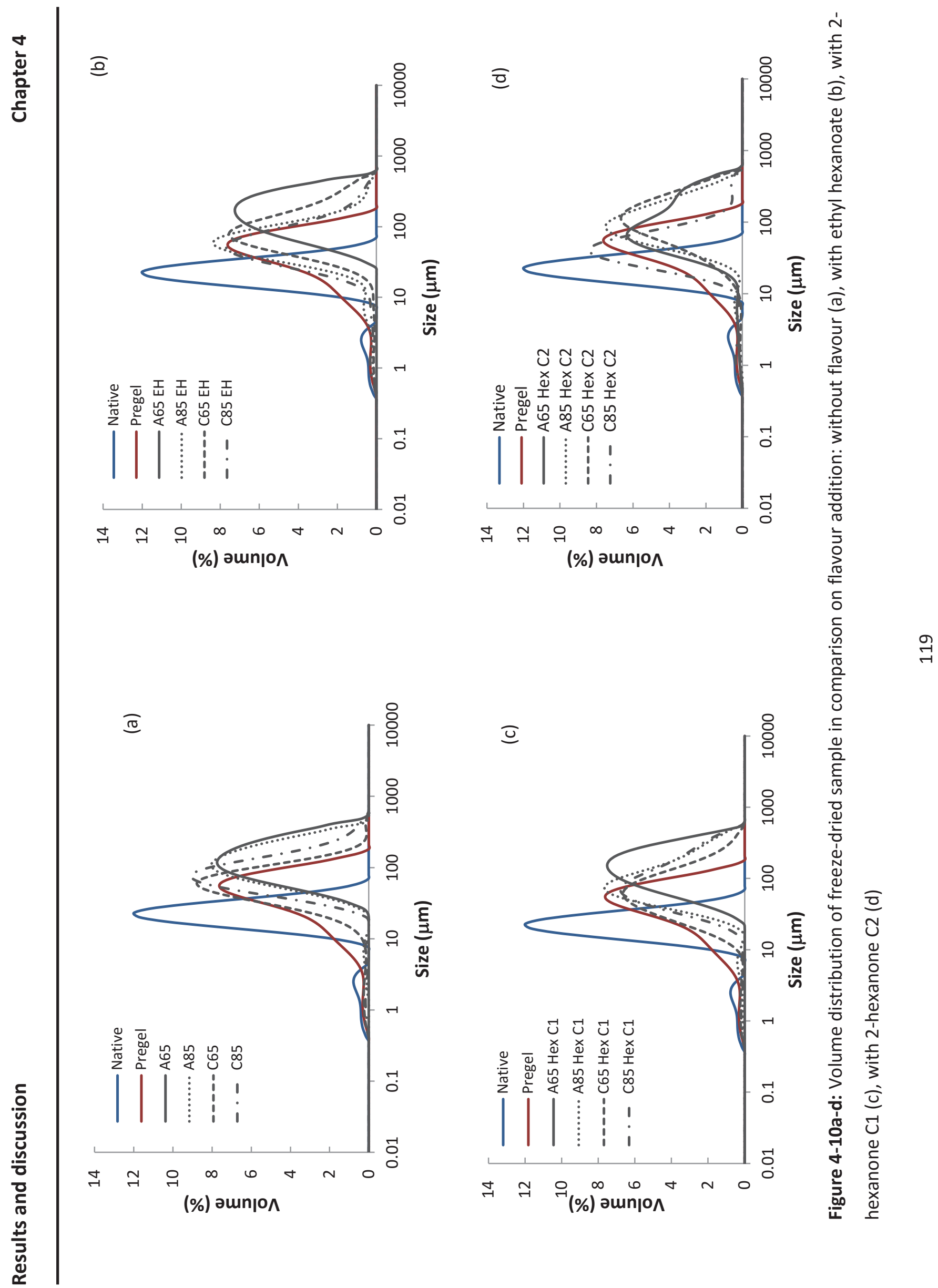


Table 4-5: The particle size parameters

\begin{tabular}{lrrrrr}
\hline Sample & \multicolumn{5}{c}{ Particle size parameter $(\boldsymbol{\mu m} \pm \mathrm{SD})$} \\
\cline { 2 - 6 } & $\mathrm{d}(\mathbf{v}, \mathbf{0 . 1})^{*}$ & \multicolumn{1}{c}{$\mathrm{d}(\mathbf{v}, \mathbf{0 . 5})^{*}$} & $\mathrm{~d}(\mathbf{v}, \mathbf{0 . 9})^{*}$ & $\begin{array}{l}\text { Volume weighted } \\
\text { mean } \mathbf{D} \mathbf{4 , 3}]\end{array}$ & $\begin{array}{l}\text { Surface weighted } \\
\text { mean } \mathbf{D}[\mathbf{3}, \mathbf{2}]\end{array}$ \\
\hline Native & $11.65 \pm 0.48$ & $23.10 \pm 0.44$ & $38.89 \pm 1.10$ & $24.00 \pm 0.48$ & $10.15 \pm 0.14$ \\
Pregel & $9.95 \pm 0.35$ & $47.01 \pm 2.38$ & $101.56 \pm 2.71$ & $52.11 \pm 1.92$ & $16.28 \pm 0.51$ \\
A65 & $56.77 \pm 0.26$ & $132.42 \pm 1.32$ & $307.40 \pm 8.48$ & $159.97 \pm 3.07$ & $108.43 \pm 0.93$ \\
A65 EH & $69.08 \pm 5.78$ & $169.03 \pm 12.34$ & $374.20 \pm 15.18$ & $197.96 \pm 11.05$ & $134.39 \pm 10.13$ \\
A65 Hex C1 & $63.29 \pm 5.19$ & $152.00 \pm 7.81$ & $343.32 \pm 17.02$ & $180.44 \pm 9.37$ & $122.29 \pm 8.50$ \\
A65 Hex C2 & $31.78 \pm 3.23$ & $92.15 \pm 7.62$ & $314.42 \pm 20.54$ & $135.10 \pm 9.90$ & $36.88 \pm 3.95$ \\
A85 & $49.73 \pm 0.99$ & $117.95 \pm 2.31$ & $270.11 \pm 9.50$ & $140.96 \pm 3.80$ & $67.49 \pm 2.50$ \\
A85 EH & $19.12 \pm 1.19$ & $59.10 \pm 1.37$ & $136.60 \pm 3.32$ & $73.15 \pm 2.29$ & $23.55 \pm 0.68$ \\
A85 Hex C1 & $36.20 \pm 0.59$ & $89.69 \pm 1.84$ & $270.28 \pm 18.50$ & $123.91 \pm 5.14$ & $42.24 \pm 1.01$ \\
A85 Hex C2 & $36.28 \pm 0.12$ & $95.35 \pm 0.32$ & $243.87 \pm 1.82$ & $120.14 \pm 0.56$ & $43.31 \pm 0.96$ \\
C65 & $28.93 \pm 7.44$ & $67.71 \pm 10.54$ & $139.59 \pm 18.81$ & $78.15 \pm 11.23$ & $28.09 \pm 6.53$ \\
C65 EH & $34.12 \pm 0.10$ & $87.15 \pm 0.67$ & $233.99 \pm 10.01$ & $114.63 \pm 2.78$ & $35.99 \pm 0.31$ \\
C65 Hex C1 & $19.89 \pm 0.06$ & $61.41 \pm 0.29$ & $171.49 \pm 3.44$ & $82.39 \pm 1.46$ & $22.20 \pm 0.11$ \\
C65 Hex C2 & $31.85 \pm 0.13$ & $108.93 \pm 0.47$ & $282.03 \pm 5.86$ & $136.15 \pm 1.60$ & $39.42 \pm 0.21$ \\
C85 & $38.80 \pm 0.02$ & $82.89 \pm 0.16$ & $184.66 \pm 2.57$ & $100.89 \pm 1.21$ & $37.04 \pm 0.06$ \\
C85 EH & $21.23 \pm 0.90$ & $57.15 \pm 1.59$ & $167.04 \pm 16.13$ & $81.86 \pm 5.14$ & $21.12 \pm 0.85$ \\
C85 Hex C1 & $31.39 \pm 0.05$ & $84.07 \pm 0.52$ & $263.82 \pm 3.42$ & $118.80 \pm 1.05$ & $32.16 \pm 0.17$ \\
C85 Hex C2 & $17.47 \pm 0.24$ & $44.27 \pm 0.78$ & $109.04 \pm 1.30$ & $60.81 \pm 0.55$ & $16.88 \pm 0.23$ \\
\hline
\end{tabular}

*These indicate $10^{\text {th }}, 50^{\text {th }}$ (median) and $90^{\text {th }}$ percentiles of volume weighted distribution.

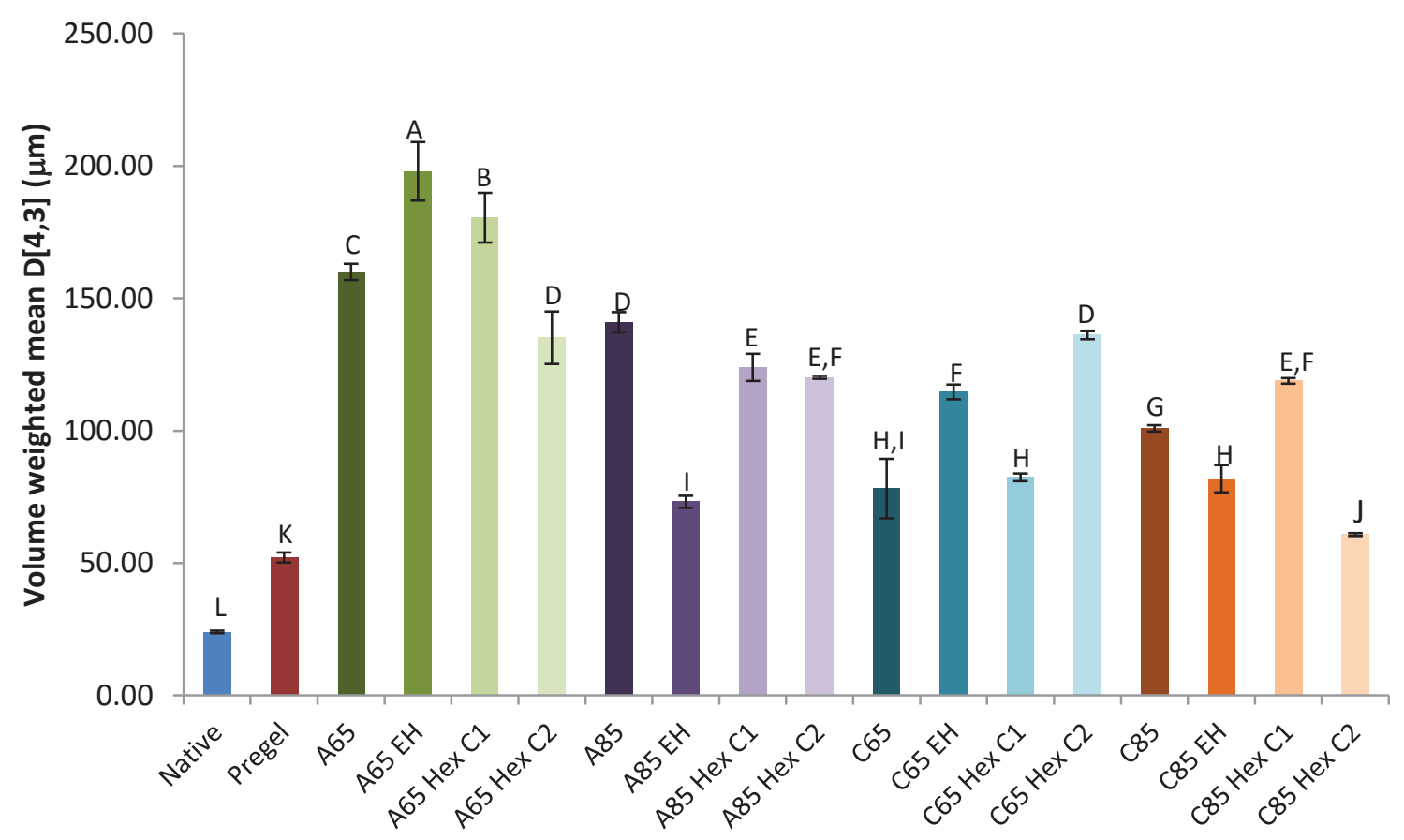

Figure 4-11: Particle size "volume weighted mean, $D[4,3]$ " - Different labels in capital letters (A-L) indicate significant difference $(P<0.001)$ at $95 \%$ confidence interval by Fisher's LSD test. 


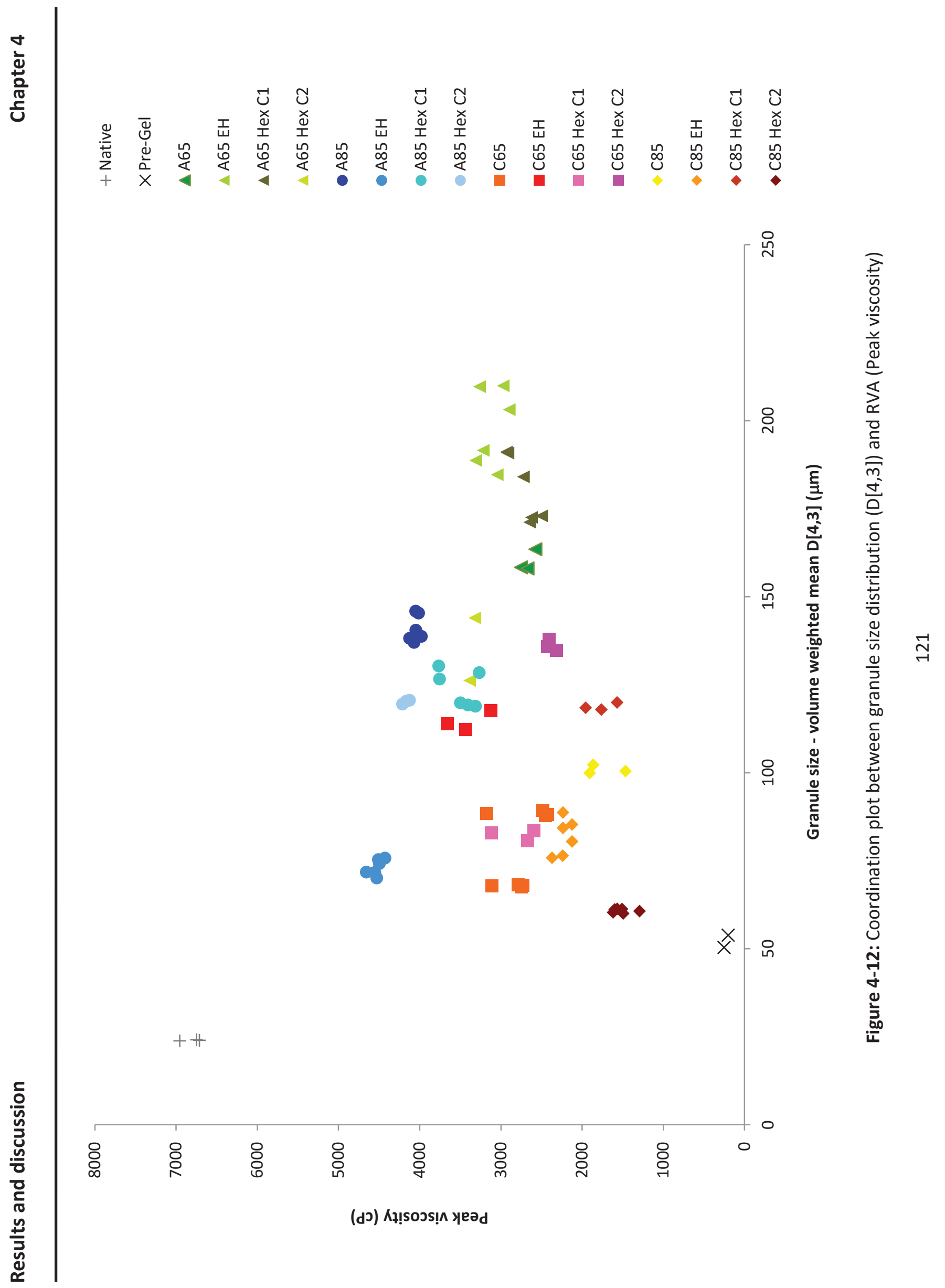




\subsubsection{X-ray diffraction (XRD) and Wide angle X-ray scattering (WAXS)}

XRD and WAXS are similar and considered as interchangeable techniques. XRD was mainly applied for crystallinity study since it is a common and rapid technique. WAXS was also later applied thanks to the availability of synchrotron beam time and sensitivity of the technique. In addition, the parallel study allows comparing the results and advantage of each technique.

The XRD diffractograms are shown in Figure 4-13 while WAXS scattering patterns and profiles are shown in Figure 4-14. Wheat starch is of A-type crystal which is characterised by its diffraction/scattering peaks at $15^{\circ}, 17.1^{\circ}, 18^{\circ}$ and $23^{\circ}(2 \theta)$ (MaacheRezzoug, Zarguili, Loisel, Queveau, \& Buleon, 2008). Diffractograms of A65 and A85 samples showed that they lost their native features and decreased in crystallinity upon hydrothermal treatment. The diffractograms of $\mathrm{C} 65$ samples showed that there are some residual native crystals while C85 samples exhibited less crystallinity compared to C65. The results of \% relative crystallinity are shown in Table 4-6. Percent relative crystallinity of wheat starch varies depending on wheat variety, growing season and study techniques (Tester, et al., 2004). In general, it ranges $20.0-27.4 \%, 36-39 \%$ and $39 \%$ by analysing with acid hydrolysis, $X-$ ray diffraction and ${ }^{13} \mathrm{C}-\mathrm{NMR}$, respectively (Buléon, et al., 1998). XRD technique revealed that native wheat starch used in this study had $32 \%$ crystallinity. The $\%$ crystallinity value determined is slightly lower than literature data which is possibly due to wheat variety, industrial starch extraction as well as analysis technique.

It is interesting that no sample, particularly A65 and A85 sample showed 0\% crystallinity by XRD which is contrast to the result of residual native starch analysis by DSC. Although \% residual native starch reported here by DSC are not comparable to \% relative crystallinity from XRD analysis, the value followed the same trend. In other words, A85 exhibited both the lowest residual native starch content (DSC) and lowest crystallinity (7\%) determined by XRD while C65 contained the highest amount of residual native and possessed the largest \% crystallinity. The different results from these two techniques are possibly due to both crystal properties and the different sensitivity of the techniques used. As the structure of samples was changed upon the treatment, the remaining parts might be different or partially melted. Therefore, the remaining crystal might require less energy to melt due to historical treatment while X-ray diffraction and scattering do not involve crystal 
melting upon analysis therefore both techniques yielded different results (Jenkins, \& Donald, 1998).

Regarding starch as a semi-crystalline polymer with low and imperfect crystallinity, its X-ray diffraction data suffers from low intensity, broad diffraction peaks, noise in the intensity scale, a large amorphous scattering distribution (Frost, Kaminski, Kirwan, Lascaris, \& Shanks, 2009). The high resolution technique coupled with data processing technique increases the quality of the obtained result. WAXS technique is capable to visualise amorphous material, which is an advantage against XRD technique for which amorphous content is only deduced from the crystalline signal. Synchrotron was the light source of WAXS technique in this study. The powerful light source and detector increase the sensitivity and detail of analysis. This study aimed at comparing the results of $\%$ relative crystallinity from both techniques (XRD and WAXS) since the calculation techniques are considered subjective (Frost, et al., 2009). The least order in amorphous materials result in poor diffraction, therefore no sharp Bragg's peak can be detected. This leads to a disadvantage of XRD technique. Although X-rays are poorly diffracted with amorphous materials, scattering can occur with high intensity. The detector and data collection technique of X-ray scattering allow one to visualise the scattering pattern of amorphous material.

Arbitrary methods of crystallinity measurements are usually employed for semicrystalline polymers, with the amorphous background estimated by drawing a smooth curve from tail to tail following the general scope of the continuous background scattering. This brings about large source of error and depending on material, which can grossly over or underestimate crystallinity (Frost, et al., 2009). The calculation technique of crystallinity from WAXS analysis used pre-gelatinised starch (100\% amorphous) as the integration baseline coupled with mathematical analysis (curve-fitting). The curve-fitting was done on module "Peak Pseudo Voigt" of Matlab®-based software (SAXSIT). The \% relative crystallinity was obtained from the \% ratio of area under the curve of a considered sample, to that of the area under the curve of pre-gelatinised starch (Figure 4-15). In Figure 4-15, blue line represents scattering profile of pre-gelatinised starch while red line represents scattering profile of each sample. Scattering profile of pre-gelatinised starch was used as baseline. The curve-fitting was done by adjusting the constant values to make the baseline fit to each scattering profile appropriately. Calculation by curve-fitting technique in 
particularly per each peak is relatively time consuming. The use of scattering profile of pregelatinised starch gives a more custom baseline and a better fit to scattering profile of the studied samples.

The results of \% relative crystallinity by WAXS were compared with those calculated by other techniques and shown in Table 4-6. The results from WAXS exhibited similar trends as in XRD. The values were approximately 1-3\% lower than the XRD ones. The results from WAXS might better reflect \% relative crystallinity since pre-gelatinised starch had the same origin as studied sample and shared baseline profile.
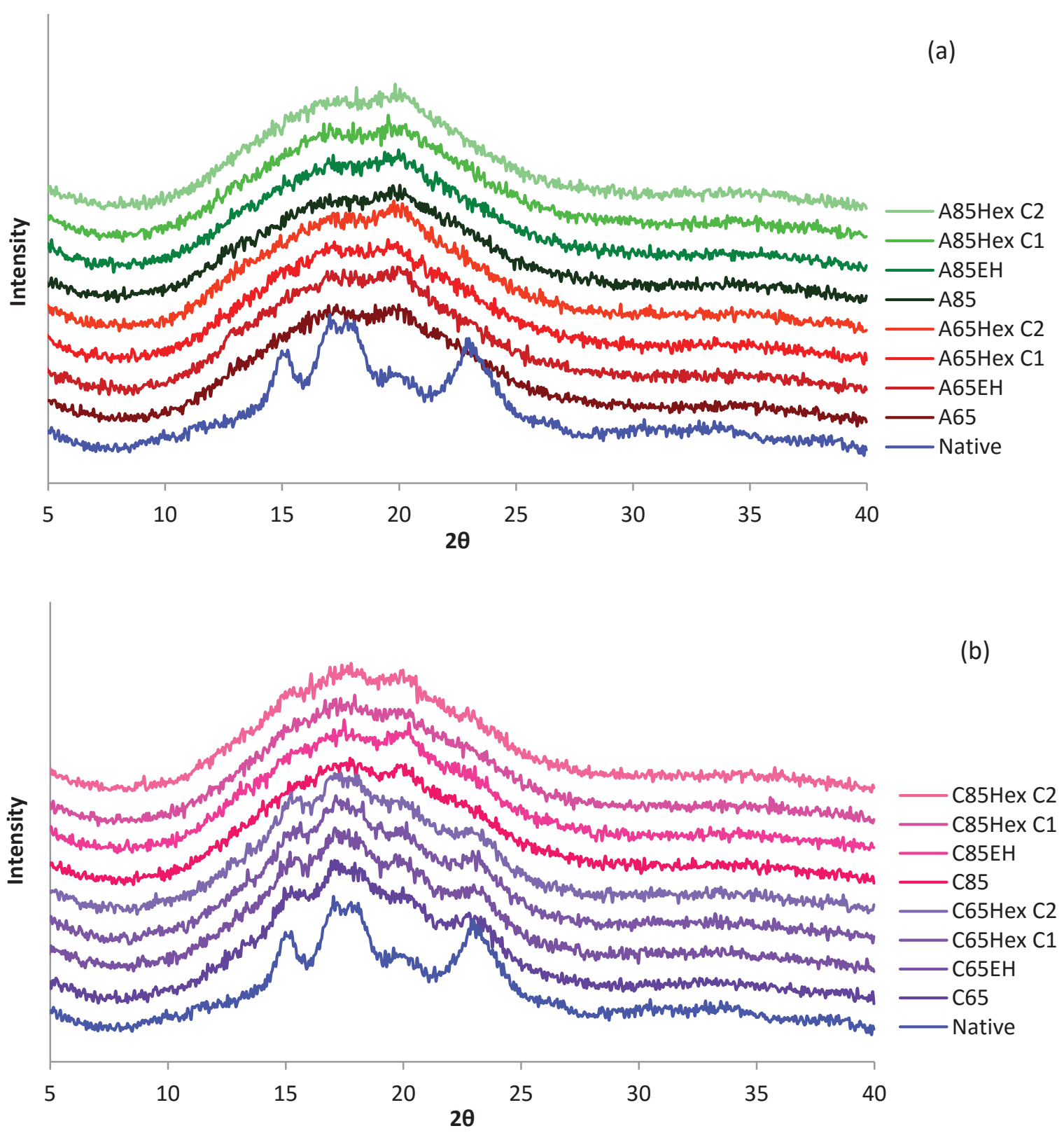

Figure 4-13a-b: Diffractograms by XRD analysis - A65 and A85 samples (a) and C65 and C85 samples (b) compared to native starch 


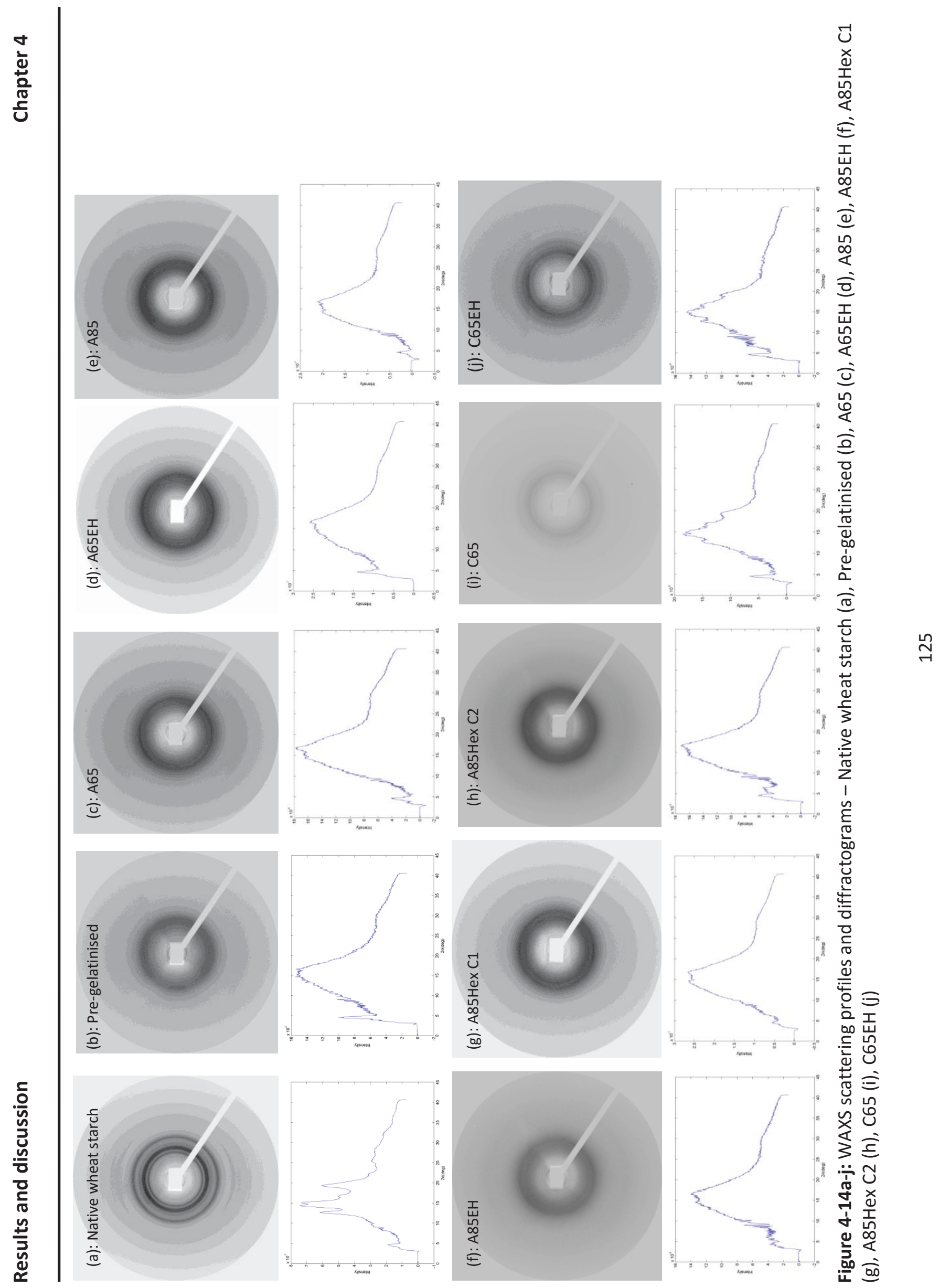




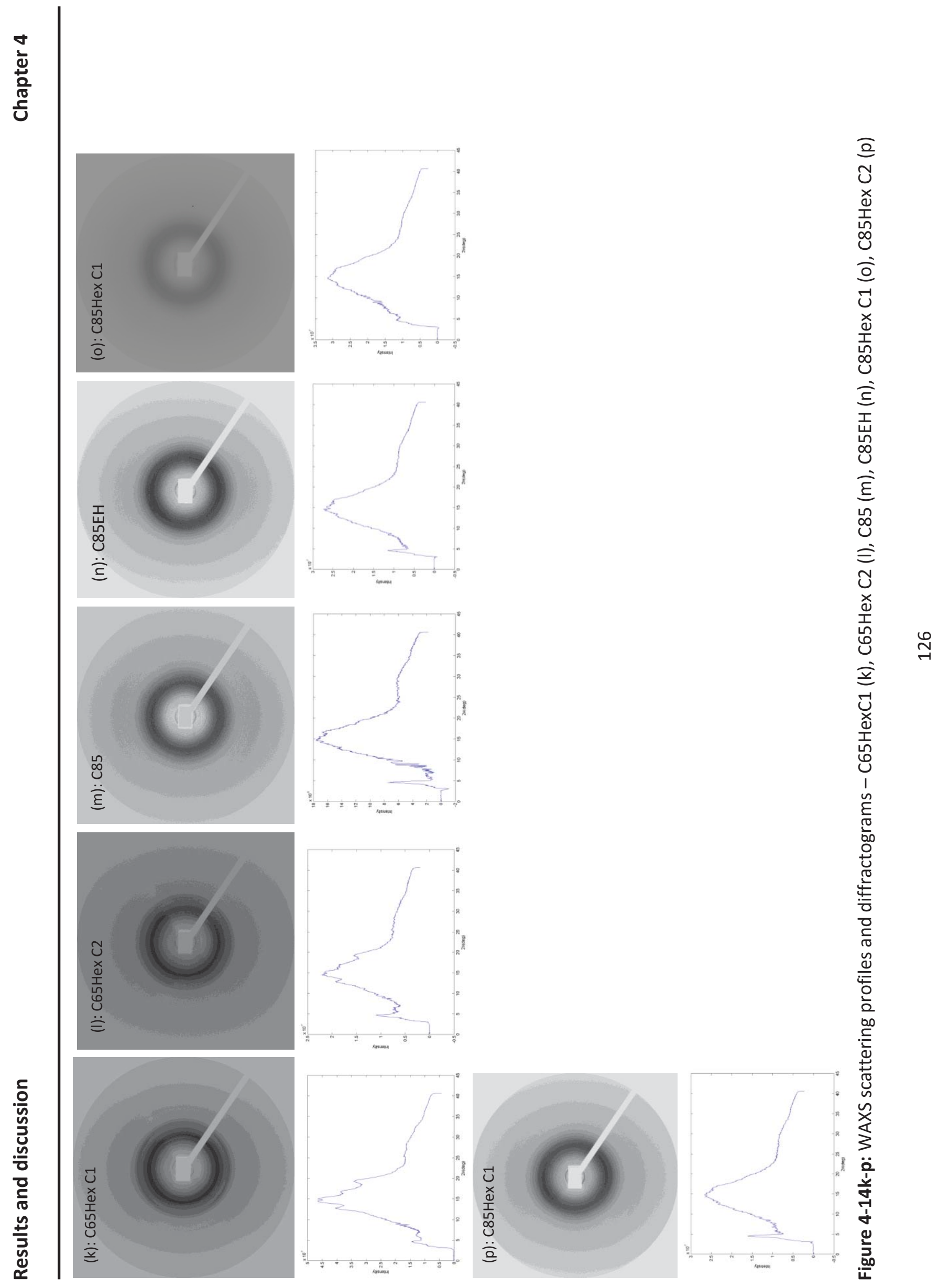



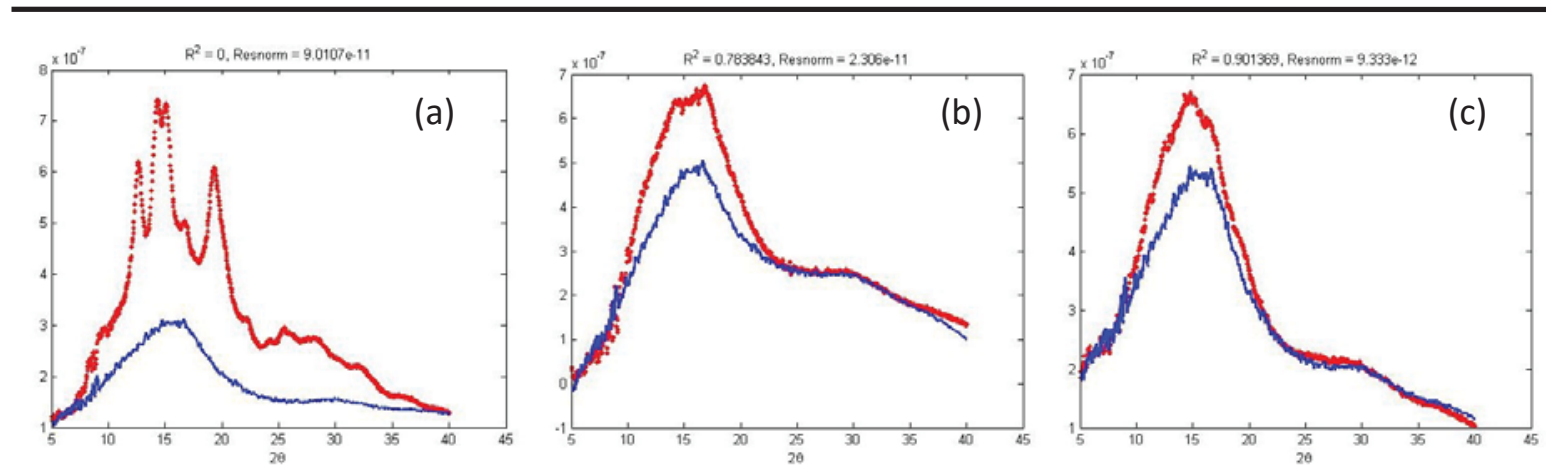

Figure 4-15a-c: Calculation of \%relative crystallinity in WAXS study by curve-fitting: Blue lines represent pre-gelatinised starch (which has been used as curve-fitting baseline), red lines native starch (a), A85 (b), C85Hex C2 (C), respectively.

Table 4-6: Degree of relative crystallinity by XRD analysis

\begin{tabular}{|c|c|c|c|c|c|}
\hline \multirow[t]{2}{*}{ Sample recipe } & \multirow{2}{*}{\begin{tabular}{|c|} 
Heating \\
Temp. \\
$\left({ }^{\circ} \mathrm{C}\right)$
\end{tabular}} & \multicolumn{2}{|c|}{$\begin{array}{l}\text { Relative crystallinity } \\
\text { (\%) }\end{array}$} & \multirow{2}{*}{\begin{tabular}{|c|}
$\begin{array}{c}\text { Residual native starch } \\
(\%)\end{array}$ \\
DSC
\end{tabular}} & \multirow[t]{2}{*}{$\begin{array}{c}\text { Starch crystal } \\
\text { type }\end{array}$} \\
\hline & & XRD & WAXS & & \\
\hline Native & NA & 31.75 & 28.89 & ND & $A$ \\
\hline Pre-gelatinised & NA & ND & $0.00 *$ & ND & - \\
\hline$A$ & \multirow{4}{*}{65} & $7.25^{c}$ & 6.16 & $2.9 \pm 0.9^{f f}$ & $\sim \mathrm{A}$ \\
\hline A+Ethyl hexanoate & & $9.03^{c}$ & 7.67 & $3.3 \pm 0.3^{f f}$ & $\sim \mathrm{A}$ \\
\hline $\mathrm{A}+2-$ Hexanone ${ }^{\mathrm{C1}}$ & & $8.02^{c}$ & ND & $8.5 \pm 2.3^{\mathrm{ee}}$ & $\sim A^{* *}$ \\
\hline $\mathrm{A}+2-$ Hexanone ${ }^{\mathrm{C} 2}$ & & $8.56^{c}$ & ND & $0.0 \pm 0.0^{f f}$ & $\sim A^{* *}$ \\
\hline$A$ & \multirow{4}{*}{85} & $7.08^{c}$ & 4.54 & $0.0 \pm 0.0^{f f}$ & $\sim \mathrm{A}$ \\
\hline A+Ethyl hexanoate & & $7.24^{c}$ & 5.23 & $0.0 \pm 0.0^{f f}$ & $\sim A$ \\
\hline $\mathrm{A}+2-$ Hexanone ${ }^{\mathrm{C1}}$ & & $7.55^{c}$ & 5.53 & $0.0 \pm 0.0^{f f}$ & $\sim A$ \\
\hline A+2-Hexanone ${ }^{\mathrm{C} 2}$ & & $7.77^{c}$ & 5.55 & $0.0 \pm 0.0^{f f}$ & $\sim \mathrm{A}$ \\
\hline $\mathrm{C}$ & \multirow{4}{*}{65} & $16.58^{\mathrm{a}}$ & 14.49 & $36.0 \pm 5.8^{b b}$ & $A$ \\
\hline C+Ethyl hexanoate & & $16.62^{a}$ & 15.98 & $40.5 \pm 3.7^{\mathrm{aa}, \mathrm{bb}}$ & $A$ \\
\hline $\mathrm{C}+2-$ Hexanone ${ }^{\mathrm{C} 1}$ & & $17.73^{a}$ & 16.31 & $36.2 \pm 4.6^{\mathrm{bb}}$ & $A$ \\
\hline $\mathrm{C}+2-$ Hexanone ${ }^{\mathrm{C} 2}$ & & $17.30^{a}$ & 15.81 & $50.5 \pm 4.5^{\text {aa }}$ & $A$ \\
\hline $\mathrm{C}$ & \multirow{4}{*}{85} & $9.33^{b}$ & 6.94 & $25.8 \pm 6.6^{\mathrm{cC}}$ & $\sim A$ \\
\hline C+Ethyl hexanoate & & $10.53^{b}$ & 7.50 & $12.8 \pm 3.5^{\mathrm{dd}}$ & $\sim \mathrm{A}$ \\
\hline C+2-Hexanone ${ }^{C 1}$ & & $10.52^{b}$ & 7.51 & $22.1 \pm 5.9^{c c}$ & $\sim \mathrm{A}$ \\
\hline $\mathrm{C}+2-$ Hexanone $\mathrm{C}^{\mathrm{C}}$ & & $11.34^{\mathrm{b}}$ & 7.93 & $13.5 \pm 5.5^{\mathrm{dd}}$ & $\sim \mathrm{A}$ \\
\hline
\end{tabular}

Different labels in superscript indicate significant difference $(P<0.001)$ at $95 \%$ confidence interval by Fisher's LSD test. Percent relative crystallinity of native starch was excluded from significance test due to extreme value.

*Pre-gelatinised starch was used as baseline (amorphous) for the calculation.

**Based on XRD profile (No data on WAXS).

NA: Not applicable

ND: No data 


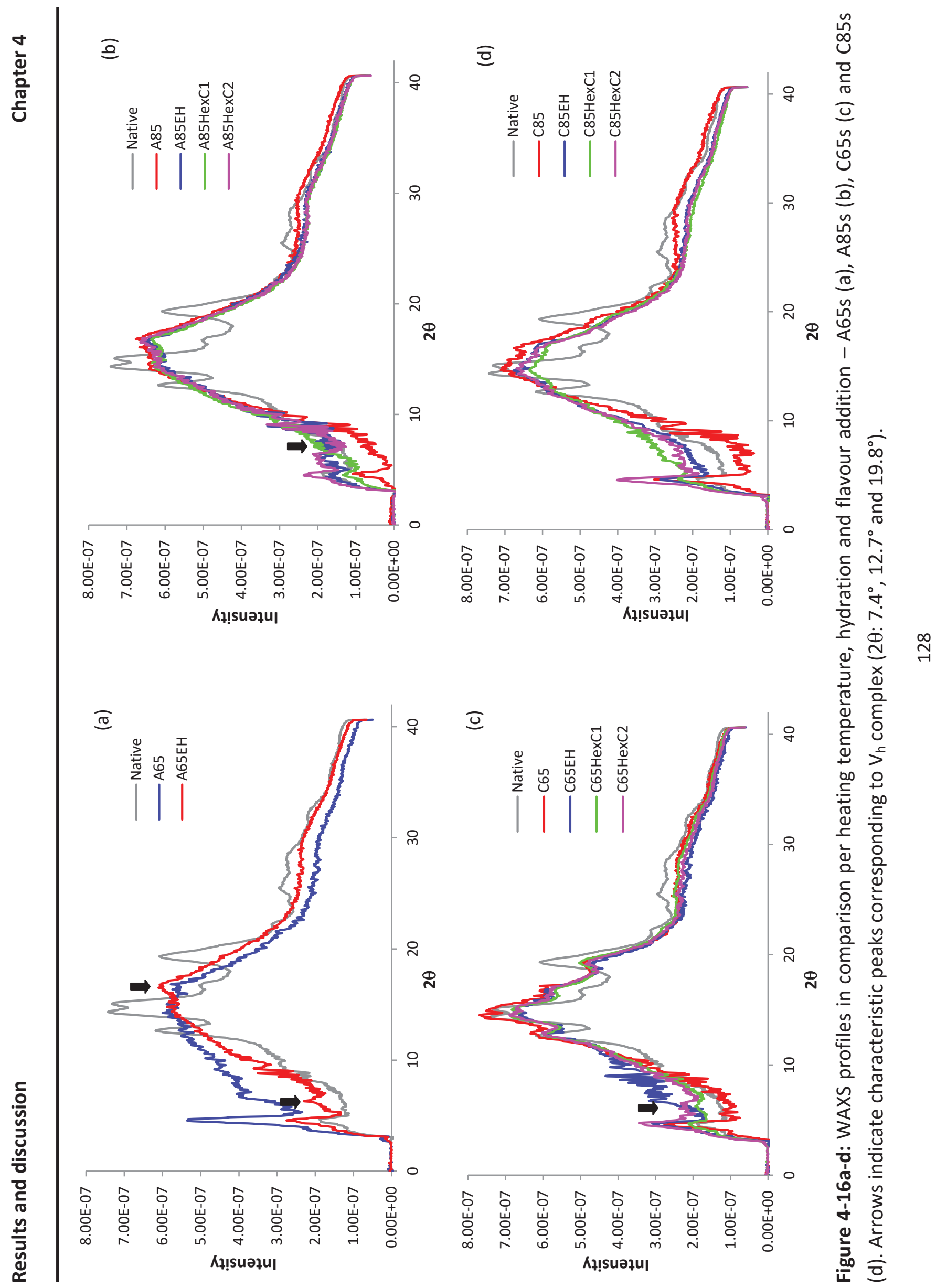


The identification $\left(A / B / V_{h}\right)$ of starch crystal type relied on WAXS data due to the better scattering resolution and image quality. The WAXS profiles from Figure 4-14 were superimposed according to the hydrothermal conditions and represented in Figure 4-16. Native wheat starch reflected A type crystal in agreement with literature data (Tang \& Copeland, 2007). B is considered as retrograded form (Jouquand, et al., 2006) and $V$ type is the sign of complex formation (Jouquand, et al., 2006; Le Bail, Rondeau, \& Buleon, 2005). No clear $V_{h}$ type pattern can be observed in any scattering profile. The reflections at $2 \theta=$ $5.3^{\circ}, 14.6^{\circ}, 17^{\circ}, 22^{\circ}$, and $24^{\circ}$ are characteristics of the $B$ type retrograded amylose (Buléon, et al., 1998; Jouquand, et al., 2006). Although the structure of A65, A85 and C85 samples showed the high peak intensity at $17^{\circ}$ DSC results of the freeze-dried powder showed no sign of retrogradation prior X-ray studies. The structure of C65 samples remained similar to their native form due to incomplete gelatinisation, the structure of A65, A85 and C85 samples were probably better classified as $\sim A$ type due to decreasing of the reflections at $2 \theta$ $=12^{\circ}, 15^{\circ}, 17^{\circ}$ and increased of reflections at $2 \theta=18^{\circ}$.

Generally, the reflection at $2 \theta$ close to $7^{\circ}, 9^{\circ}, 12^{\circ}, 13^{\circ}, 17^{\circ}$, and $18^{\circ}$ are attributed to the marker peaks of complexes (Derycke, et al., 2005; Jouquand, et al., 2006; Tang \& Copeland, 2007). Considering Figure 4-14 in detail and comparing each sample of a given treatment with flavour to the one without flavour, there seems to be differences in peak intensity for some samples. A65EH showed increasing peak intensity at $2 \theta: 7^{\circ}$ and $17^{\circ}$. $\mathrm{A} 85 \mathrm{EH}, \mathrm{A} 85 \mathrm{HexC2}, \mathrm{C} 65 \mathrm{HexC} 1$ and $\mathrm{C} 65 \mathrm{HexC2}$ showed increasing peak intensity at $2 \theta: 7^{\circ}$. Although it could not be associated with the peak of complex because the peaks cannot be obviously distinguished, this is an interesting observation of complex formation and detection since Derycke et al. (2005) demonstrated that complex can be formed under heatmoisture treatment with moderate ( $40 \%$ moisture content) and low moisture content ( $25 \%$ moisture content) (Derycke, et al., 2005). In order to confirm the presence of complex, more study is required particularly comparing the results with those of a control sample washed (to remove uncomplexed flavour) with solvent (e.g. 50\% ethanol) which would also improve scattering profile (Biais, et al., 2006).

The study of inclusion complex formation between starch and fatty acid indicated that the formation of complexes is primarily governed by solubility/dispersibility of the fatty acid in water which in turn depends on variables such as temperature and 
molecular weight and shape (Fanta, et al., 1999). It could be similar with the flavours used in the present work. Moreover, the treatment conditions (e.g. low water content, presence of amylopectin, no stirring) are proved to be factors affecting complex formation (Jouquand, et al., 2006). Jouquand et al. (2006) reported that 2-hexanone is unable to form complex, whereas Wulff et al. (2005) reported the contrary. The latter explained that small molecules such as 2-hexanone show low association constants compared to longer or cyclic molecules (Wulff, et al., 2005). Regarding the contradiction between these 2 studies, the type of ligand and carbohydrate used should be taken into account. They are directly involved in binding capacity which, finally leads to different results and degree of complex formation (Jouquand, et al., 2006; Wulff, et al., 2005).

It is widely accepted that excess water and gelatinisation conditions promote complex formation. Solubility of guest molecule in starch mixture is a crucial point of complex formation. Lipids for instance, possibly interact with water, form complex with amylose in starch or self-associate into micellar structures (Tang \& Copeland, 2007). Upon thermal treatment, amylose leaching occurs; and viscosity develops as well as amylose network formation. At low moisture content, the concentration of water could be too low to both fully destruct starch structure and prevent helical dissociation therefore the guest molecules are unable to enter into the helix. Optimum solubility promotes interaction between starch and guest molecule resulting in high degree of complex formation.

Regarding the influence of hydrothermal treatment on structure, the treatment parameters were demonstrated to bring about different sample properties. The hydration level was involved in degree of granule swelling and crystal melting whereas temperature was involved in structure reorganisation. A65 and A85 samples were not significantly different in \% relative crystallinity however they were different in pasting properties and granule size. This is because water promoted a better swelling at $65^{\circ} \mathrm{C}$ and could contribute to a structure reorganisation upon annealing $(A 65)$. At $85^{\circ} \mathrm{C}$, the temperature is too high for annealing but it is suitable for crystal melting and gelatinisation. The process of crystal melting and gelatinisation at $85{ }^{\circ} \mathrm{C}$ were speculated to occur rapidly and even before the granules reached their maximum swelling. In comparison to A85 conditions, A65 were milderly treated, therefore crystal melting and gelatinisation were expected to occur slower which allowed the granules to swell more than A85. This is in accordance with Mulumba et al., (2013) that the granules of wheat starch swell in different extent between $50-60{ }^{\circ} \mathrm{C}$ and 
80-90 ${ }^{\circ} \mathrm{C}$. Both $\mathrm{C}$ samples exhibited a larger relative crystallinity than $\mathrm{A}$ samples due to lower hydration level. Both C samples are not significantly different in granule size but C65 had a greater relative crystallinity than C85. The effect of temperature at low hydration on pasting profile was opposite to high hydration level (A samples). The conditions of C85 allowed water to access crystalline regions and high temperature facilitated crystal melting directly but the amount of water was insufficient for granule complete swelling (Waigh, Gidley, et al., 2000). In case of C65, low temperature limited crystal melting and water was less accessible into crystalline regions therefore the available water was prompt to promote swelling instead.

The result of \% relative crystallinity suggested that there was no significant difference due to flavour addition. The remaining quantities of flavour inside the sample could have been then too low to influence structural alteration as well as to cause formation of inclusion complex. However, the residual flavour quantities showed the influence on pasting profile.

\section{Box 6: 4.1.5.2 Section highlight}

- \% relative crystallinity from XRD and WAXS were slightly different (2-3\%) due to curvefitting technique but they were in agreement.

- \% crystallinity: C65>C85>A65>A85.

- The diffraction profiles suggested that samples were still in their native crystal form.

- The detection of flavour-inclusion complex remained unclear.

\subsubsection{Small angle X-ray scattering (SAXS)}

SAXS analysis was used for a further study of starch at sub-granular level. SAXS measurement was performed at $q$ ranges of $0.2-2.2 \mathrm{~nm}^{-1}$. According to Bragg's diffraction, the scattering vector of native wheat starch was transformed into interplanar spacing of the crystal or of semi-crystalline lamellae repeat distance (d) as showed in Figure 4-17. It can be clearly seen from the figure that $d$-spacing of native wheat starch is $\sim 10 \mathrm{~nm}\left(q=0.63 \mathrm{~nm}^{-1}\right)$. This result is similar to the SAXS study of small and larger wheat granules where the dspacing varies between 9.2-9.8 $\mathrm{nm}$ (Vermeylen, et al., 2005). The treated samples were also 
subjected to SAXS measurement and their SAXS profiles (plotted between intensity versus scattering vector $(q))$ are shown in Figure 4-18.

In order to understand the effect of hydrothermal treatment at sub-granular level, the obtained results were subjected to mathematical analysis (curve-fitting). Prior to curve-fitting, the intensity and scattering vector values were transformed into log values. The curve-fitting was done on module "Guinier and Porod Fit" of Matlab ${ }^{\circledR}$-based software (SAXSIT). Data selections for curve-fitting are shown in Figure 4-19. The results of pregelatinised starch were the only ones perfectly fitted with a linear model: the curve was fitted at $q$ range of $0.02-0.22 \mathrm{~nm}$. The curve-fitting range (log-log scale plot of SAXS profile) for other samples were selected as in Figure 4-20.

Regarding Figure 4-20a, the difference between native starch, and pregelatinised starches can be distinguished. There is no scattering peak observed (flat line) in pre-gelatinised starch as its semi-crystalline regions were disrupted by industrial gelatinisation process. Scattering peak was not observed as the in sample A65 and A85 (Figure 4-20b-c) whereas a tiny scattering peak can be observed in sample C65 and C85 (Figure 4-20d-e). These results evidence that hydration level affected semi-crystalline regions which are totally disrupted at high hydration level. It is interesting to compare the results between A samples and pre-gelatinised starch. Although, the SAXS results showed that the crystalline regions disappeared from both samples their scattering profiles were not identical. This reflects the different degrees of crystal melting or granule disruption and structure. According to DSC results (Table 4-6), pregelatinised and A samples contained no residual of native starch however, the results of XRD and WAXS suggested that some crystalline material remained in samples A. Since no peak can be observed by SAXS analysis, the crystalline lamellae were suggested to be disrupted upon treatment but the crystal melting of A sample were not completed (according to XRD and WAXS results). SAXS scattering profiles also demonstrated that $A 65$ and $A 85$ samples were similar but not totally identical A85s profiles being more linear than A65s. This is due to the different extent of the heating treatment which increased the disruption of semi-crystalline region in A85.

SAXS scattering profiles of $C$ samples before curve-fitting confirmed that there was insufficient water to complete a full breakup of the semi-crystalline regions as the lines were not absolutely flat (peaks can be observed) in comparing to pre-gelatinised starch (Figure 4-18 and Figure 4-20). However, those semi-crystalline regions in C samples were 
different from native starch. Comparing SAXS scattering profile (before curve-fitting) of C65s and C85s, it was found that they were not identical.

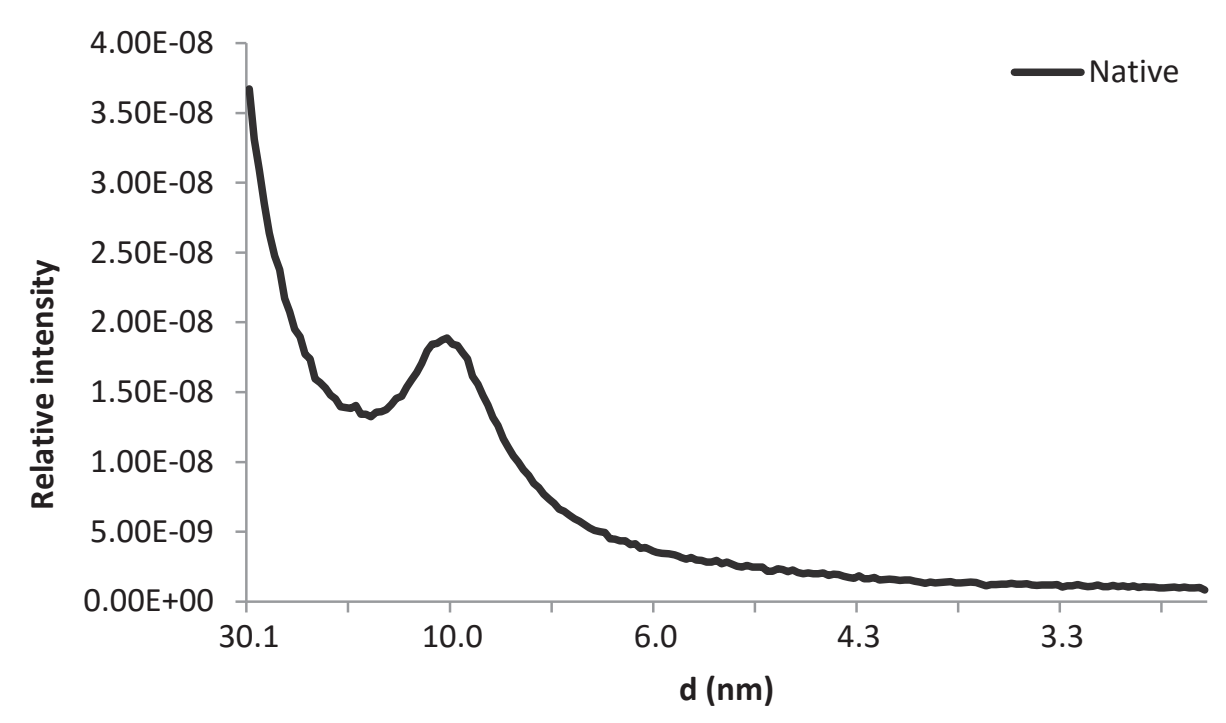

Figure 4-17: Relative intensity versus thickness of crystalline-amorphous layers " $d$-spacing" of native wheat starch

The results of curve-fitting ( $\alpha$ and $\beta$ values of linear model) are shown in Table 47. In order to clarify the effect of hydrothermal treatments on the semi-crystalline regions and compare the different samples, the result of $\alpha$ values $\left(\alpha_{1}\right.$ and $\left.\alpha_{2}\right)$ were subjected to analysis of ANOVA. As above mentioned, the fitting range at $q$ equal to $0.02-0.22 \mathrm{~nm}$ can be applied to pre-gelatinised starch only, therefore analysis of ANOVA was performed separately at $q$ equal to $0.02-0.05$ and $0.07-0.22 \mathrm{~nm}$. This is to show the effect of hydrothermal treatments at $\mathrm{d}: 3.0-1.0$ and 0.9-0.3 $\mathrm{nm}$, respectively.

Analysis of ANOVA on $\alpha$ values of SAXS scattering profile suggested that samples As and Cs are significantly different from native and pre-gelatinised starch as well as samples As and Cs are significantly different from each other. In SAXS like in DSC, XRD and WAXS no significant effect of flavour addition can be observed. It is possible that the residual contents are too low to affect the structure as well as too low to be detected.

The small peaks detected by SAXS reflected that semi-crystalline regions in both C65 and C85 were not totally collapsed due to low hydration however the higher temperature in C85 resulted in the greatest change. This result is in accordance with XRD and WAXS results. It confirms the role of temperature in semi-crystalline destruction under 
limiting water. According to SAXS measurements, there are 2 possibilities to explain the phenomena. At high hydration level, starch granules require certain temperature for melting and collapsing of semi-crystalline region. The results of DSC and RVA could suggest that the optimal temperature is approximately $62-66{ }^{\circ} \mathrm{C}$ which derived from DSC peak temperature and RVA pasting temperature. This is similar to the suggestion by Vermeylen et al., (2006) that crystallinity of A-type starches is lost in the temperature region roughly corresponding to the DSC gelatinisation range (Vermeylen, Derycke, et al., 2006). The higher heating temperature could not further alter the structure of starch. However, the different heating degrees resulted in different granule size and pasting properties. At low hydration level, there were insufficient in water and accessibility of water was limited. In this case, swelling was inhibited but crystalline melting was driven by heating temperature: the higher temperature the greater the structural destruction.

\section{Box 7: 4.1.5.3 Section highlight}

- At high hydration at both temperatures, SAXS suggested that semi-crystalline regions were collapsed.

- At low hydration, the semi-crystalline regions could still be detected. However, the higher temperature the greater crystal melting. 


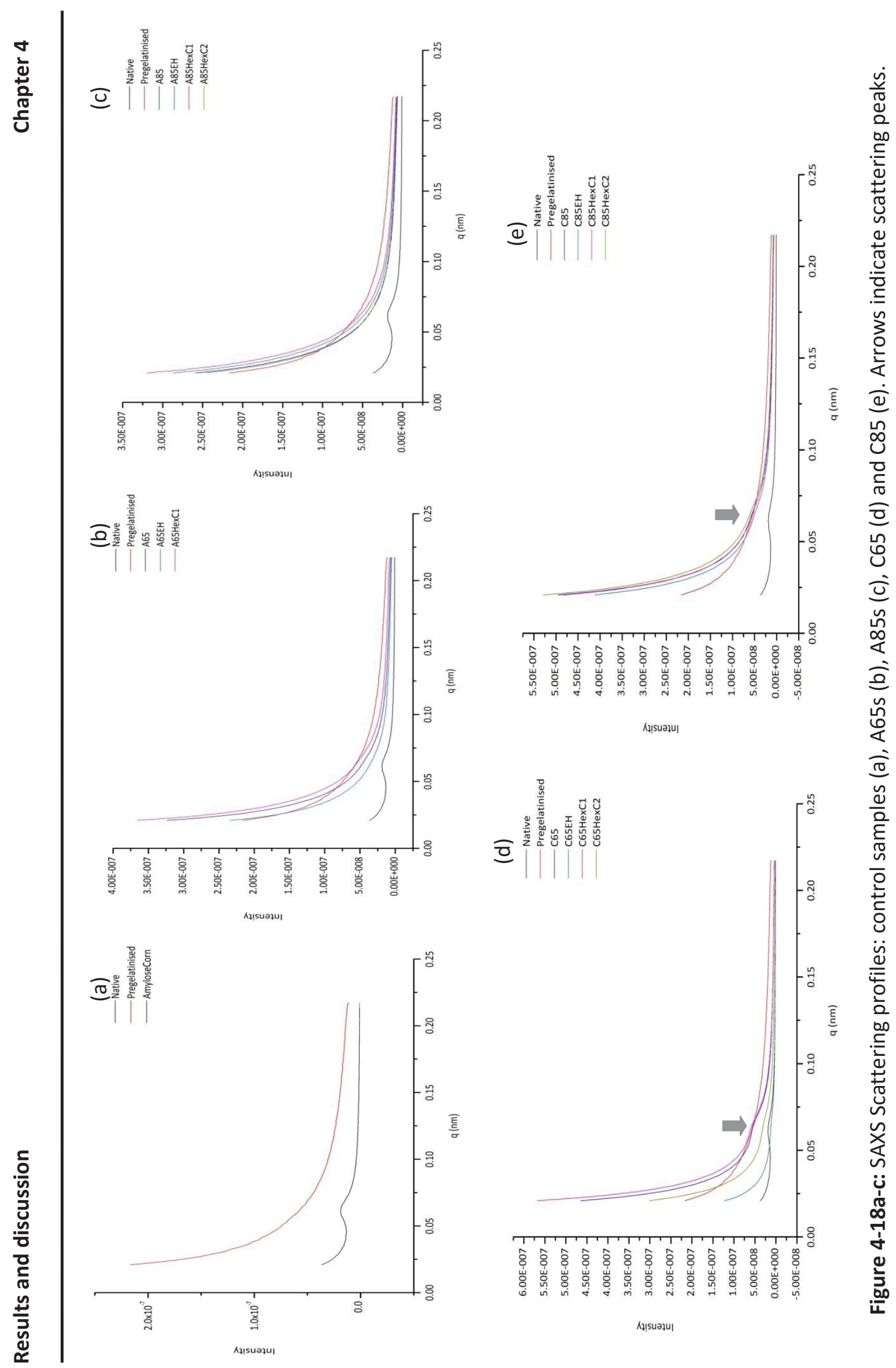



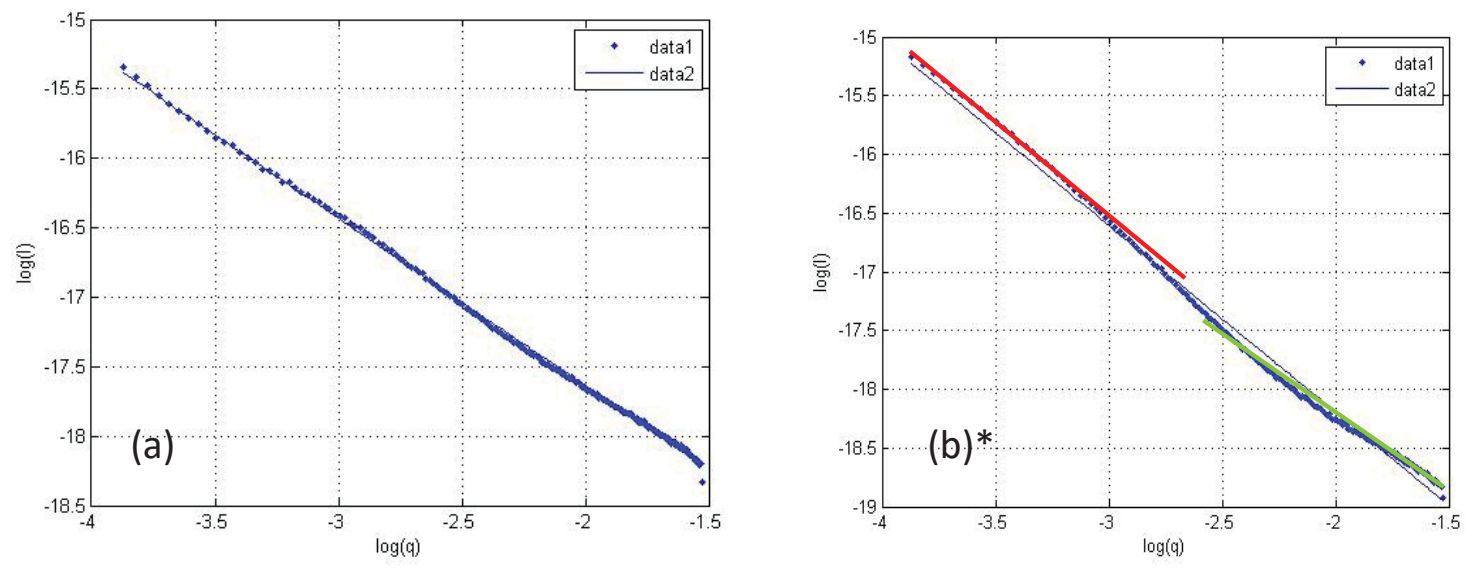

*Red and green lines represent the adjustment of linear-fitting, which applied to all samples except pregelatinised starch.

Figure 4-19: Linear-fit of SAXS scattering profile - $\log ($ Intensity) versus $\log (q)$ : Optimal-fit of pre-gelatinised starch (a), adjusted-fit of A85 (b)

Table 4-7: SAXS Fitting parameters

\begin{tabular}{lcccccc}
\hline Sample & \multicolumn{6}{c}{ Fitting range : q (Zhu, Jackson, Wehling, \& Geera) } \\
\cline { 2 - 7 } & \multicolumn{1}{c}{ Fitting 1: } & $\mathbf{0 . 0 2 - 0 . 2 2}$ & \multicolumn{1}{c}{ Fitting 2: $\mathbf{0 . 0 2}-\mathbf{0 . 0 5}$} & \multicolumn{1}{c}{ Fitting 3: 0.07-0.22 } \\
\cline { 2 - 7 } & $\boldsymbol{\alpha}_{1}$ & $\boldsymbol{\beta}_{\mathbf{1}}$ & $\boldsymbol{\alpha}_{2}$ & $\boldsymbol{\beta}_{\mathbf{2}}$ & $\boldsymbol{\alpha}_{3}$ & $\boldsymbol{\beta}_{\mathbf{3}}$ \\
\hline Native & -1.76 & -23.44 & $-1.37^{\mathrm{A}}$ & -22.50 & $-2.06^{\mathrm{D}}$ & -24.06 \\
Pre-gelatinised & -1.21 & -20.05 & $-1.21^{\mathrm{A}}$ & -20.05 & $-1.21^{\mathrm{A}}$ & -20.053 \\
\hline A65 & -1.68 & -21.54 & $-1.76^{\mathrm{B}}$ & -21.77 & $-1.40^{\mathrm{A}}$ & -20.01 \\
A65 EH & -1.61 & -21.62 & $-1.84^{\mathrm{B}}$ & -22.02 & $-1.27^{\mathrm{A}}$ & -20.99 \\
A65 Hex C1 & -1.62 & -21.21 & $-1.72^{\mathrm{B}}$ & -21.50 & $-1.28^{\mathrm{A}}$ & -20.57 \\
A65 Hex C2 & -1.28 & -20.07 & $-1.57^{\mathrm{B}}$ & -21.23 & $-1.25^{\mathrm{A}}$ & -20.51 \\
\hline A85 & -1.59 & -21.37 & $-1.74^{\mathrm{B}}$ & -21.82 & $-1.27^{\mathrm{A}}$ & -20.77 \\
A85 EH & -1.57 & -21.21 & $-1.72^{\mathrm{B}}$ & -21.63 & $-1.30^{\mathrm{A}}$ & -20.69 \\
A85 Hex C1 & -1.58 & -21.14 & $-1.74^{\mathrm{B}}$ & -21.59 & $-1.27^{\mathrm{A}}$ & -20.56 \\
A85 Hex C2 & -1.53 & -21.20 & $-1.70^{\mathrm{B}}$ & -21.71 & $-1.19^{\mathrm{A}}$ & -20.56 \\
\hline C65 & -2.04 & -22.58 & $-2.14^{\mathrm{D}}$ & -22.92 & $-1.67^{\mathrm{C}}$ & -21.89 \\
C65 EH & -2.06 & -24.09 & $-2.26^{\mathrm{D}}$ & -24.71 & $-1.64^{\mathrm{C}}$ & -23.00 \\
C65 Hex C1 & -2.13 & -22.74 & $-2.24^{\mathrm{D}}$ & -23.10 & $-1.86^{\mathrm{C}}$ & -22.23 \\
C65 Hex C2 & -2.10 & -23.24 & $-2.22^{\mathrm{D}}$ & -23.65 & $-1.80^{\mathrm{C}}$ & -22.68 \\
\hline C85 & -1.80 & -21.68 & $-1.99^{\mathrm{C}}$ & -22.25 & $-1.50^{\mathrm{B}}$ & -21.11 \\
C85 EH & -1.76 & -21.68 & $-1.88^{\mathrm{C}}$ & -22.02 & $-1.45^{\mathrm{B}}$ & -21.09 \\
C85 Hex C1 & -1.81 & -21.71 & $-1.93^{\mathrm{C}}$ & -22.04 & $-1.52^{\mathrm{B}}$ & -21.17 \\
C85 Hex C2 & -1.79 & -21.55 & $-1.94^{\mathrm{C}}$ & -21.98 & $-1.40^{\mathrm{B}}$ & -20.82 \\
\hline
\end{tabular}

Different labels in superscript indicate significant difference $(P<0.001)$ at $95 \%$ confidence interval by Fisher's LSD test. $\alpha_{1}$ was excluded from significant test due to fitting range resulted in inappropriate models. 

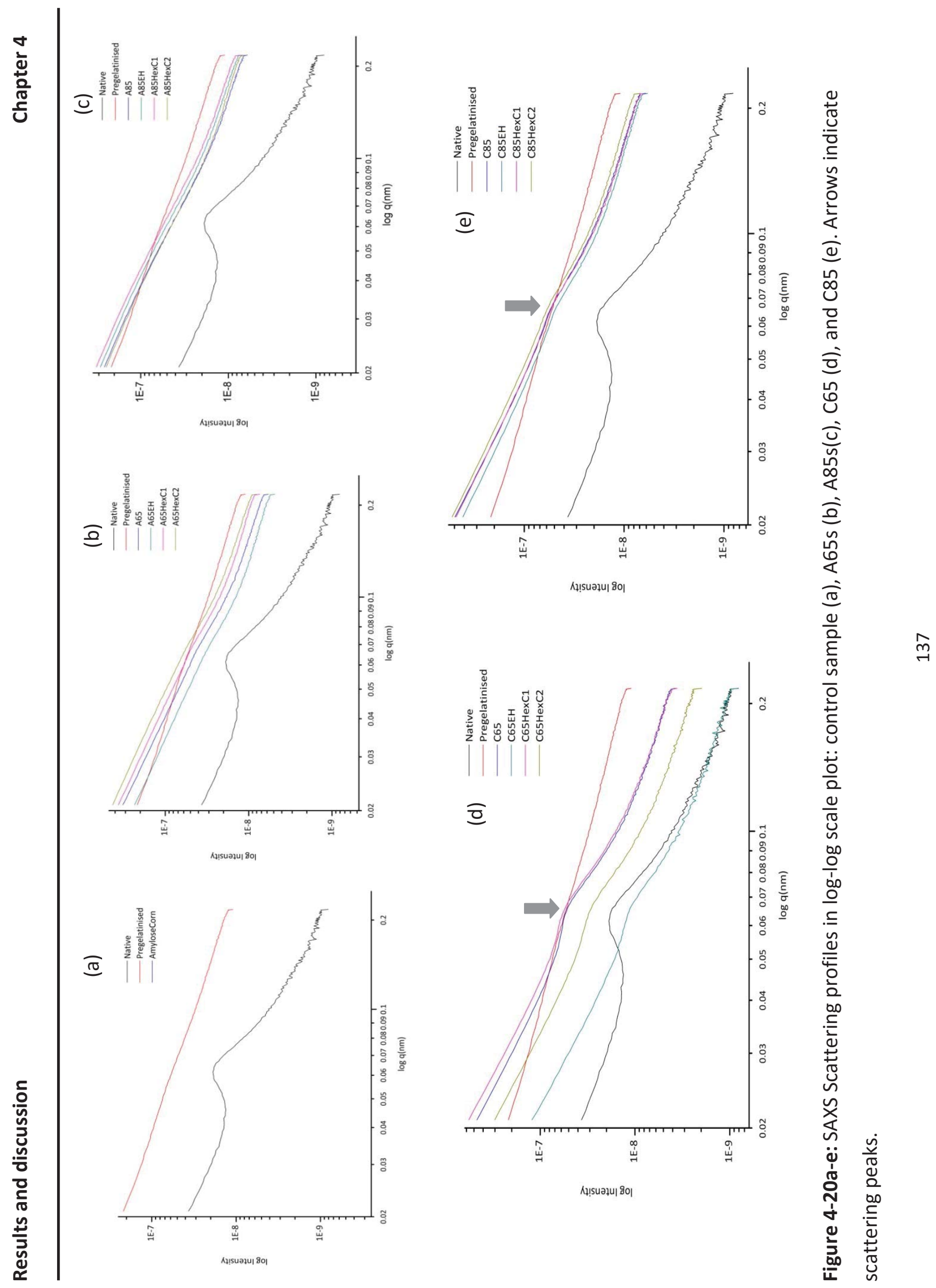

ñ

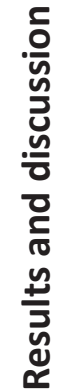

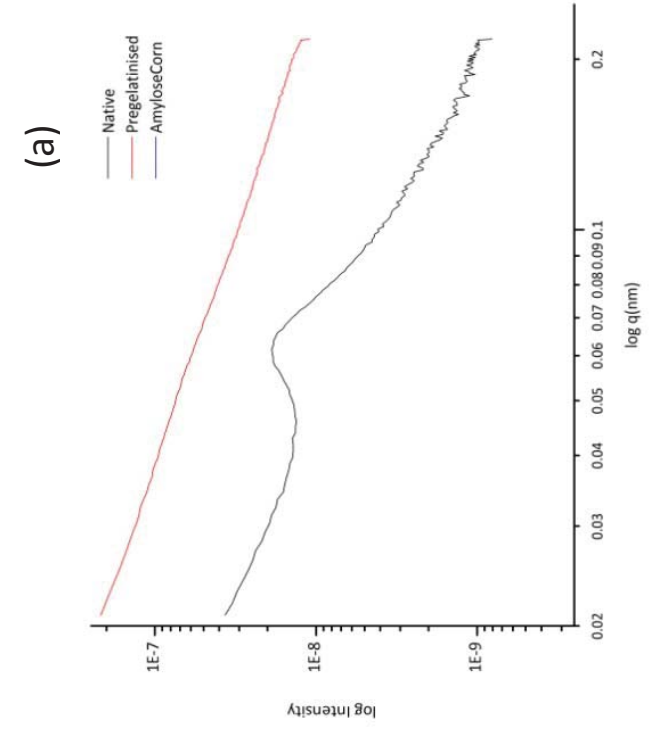


Box 8: 4.1 Effect of hydrothermal treatment

- Hydrothermal treatment greatly affected flavour loss due to vapourisation which was the highest for $\mathrm{A} 85$.

- DSC, XRD and WAXS were unable to detect flavour inclusion complex which might due to low residual content or no complex formation.

- The effects of hydrothermal treatment on pasting profile and granule size were different due to hydration level. At high hydration, the influences were similar to annealing while at low hydration, the influences were similar to heat-moisture treatment.

- The XRD, WAXS and SAXS results suggested that crystal melting firstly occurred in the amorphous region. However, the low temperature $\left(65^{\circ} \mathrm{C}\right)$ better promoted granule swelling but reduced peak viscosity. At low hydration, granule swelled the similar extent but the temperature affected pasting profile and crystal melting. The higher temperature $\left(85^{\circ} \mathrm{C}\right)$ reduced peak viscosity but induced greater crystal melting. 


\subsection{Storage study}

The sample stability has been studied versus time through 2 aspects: 1) considering how the flavour content evolved in the different samples and 2) considering structural relaxation.

The assay of flavour content indicated that there were residual flavours in the samples after freeze-drying. Although structural analysis could not evidence the presence of flavours complexed with starch, it is interesting to monitor the residual flavour content versus time: i.e. characterising possible release. On the one hand flavour stability might be affected by the matrix stability and on the other hand, the sample stability is possibly affected by the residual flavour. Flavour release and retention upon storage were applied as the key points to understand flavour stability upon storage.

Moisture is well known as a possible cause for low humidity products physical degradation: through increased molecular mobility and structural evolution rate (Roos, 2010). Hence, the storage study was conducted at intermediate relative humidity (58 and 75 $\% \mathrm{RH})$ to shorten study time, as a result of increased humidity, evolution kinetics are expected to increase. The amount of 2-hexanone $\mathrm{C} 1$ was too low for the storage study thus samples with ethyl hexanoate were compared to those with 2-hexanone C2.

\subsubsection{Stability of flavour upon storage}

\subsubsection{Flavour release study by Static Headspace-Solid Phase Micro Extraction} (SH-SPME)

Freeze-dried samples were stored in headspace vials and withdrawn for analysis after 2, 4 and 14 weeks of storage. As above mentioned, the samples with higher amount of 2-hexanone were chosen for storage study. To avoid the bias occurring from the different initial amount (initial concentration of 2-hexanone ten times greater than for ethyl hexanoate), the vapour/solid ratio was calculated based on flavour amount within headspace as a ratio to quantity within each sample after freeze-drying and prior to storage study. The results of SPME were reported in Figure 4-21. The additional figures and extraction report (in $\mu \mathrm{g}$ ) of these results can be found in Appendix 1 (Figure A-1 and A-2).

Figure 4-21a represented SPME results at 58\% RH. The amount of released ethyl hexanoate in $\mathrm{A} 85$ and $\mathrm{C} 85$ gradually increased upon storage and reached its maximum at 14 weeks. All samples showed no significant difference in ethyl hexanoate release at 2 weeks. 
However at 14 weeks, the amount of flavour released from A85 and C85 samples markedly increased to reach a level significantly greater than A65 and C65. The releases of 2hexanone were constant throughout study time, except for A85 that significantly reduced. There seemed to be no effect of time on release of 2-hexanone at $58 \% \mathrm{RH}$.

Figure 4-21b represents SPME results at $75 \% \mathrm{RH}$. It was found that ethyl hexanoate was significantly more released than 2 -hexanone at $75 \% \mathrm{RH}$ for all samples. It is interesting to compare the released pattern of both flavours. Expectedly, the released amount of ethyl hexanoate was the lowest at 2 weeks storage, then reached the highest amount at 4 weeks and finally declined at 14 weeks but remained greater than the amount at 2 weeks in all samples. The released amount of ethyl hexanoate in each sample at each time interval was significantly different. The highest released amount was found in C65 followed by $\mathrm{A65}, \mathrm{A} 85$ and $\mathrm{C} 85$, respectively. It is interesting to see the decreasing amount of ethyl hexanoate at 14 weeks. The decreasing release of ethyl hexanoate at $75 \% \mathrm{RH}$ at 14 week were possibly due to mobilities of the flavour and water within the system. It is possible that the systems were not at equilibrium of flavour and water vapours. It is also speculated that the system's mobility associated with absorption of water by starch during storage and led to releasing of flavour. Considering flavour residual contents within the sample, they can be considered as trace amounts whereas the water was more abundant. A small change of water mobility due to structural evolution upon storage could greatly affect flavour release. The experimental time might be too short and the flavour release can expected to level off later than 14 weeks of storage.

The released amount of 2-hexanone was found comparable for all 665 samples throughout study time, at a similar level as for A85. The figure suggests that the lowest released 2-hexanone content was found for A65, however it was not significantly different from A85, C65 and C85. 


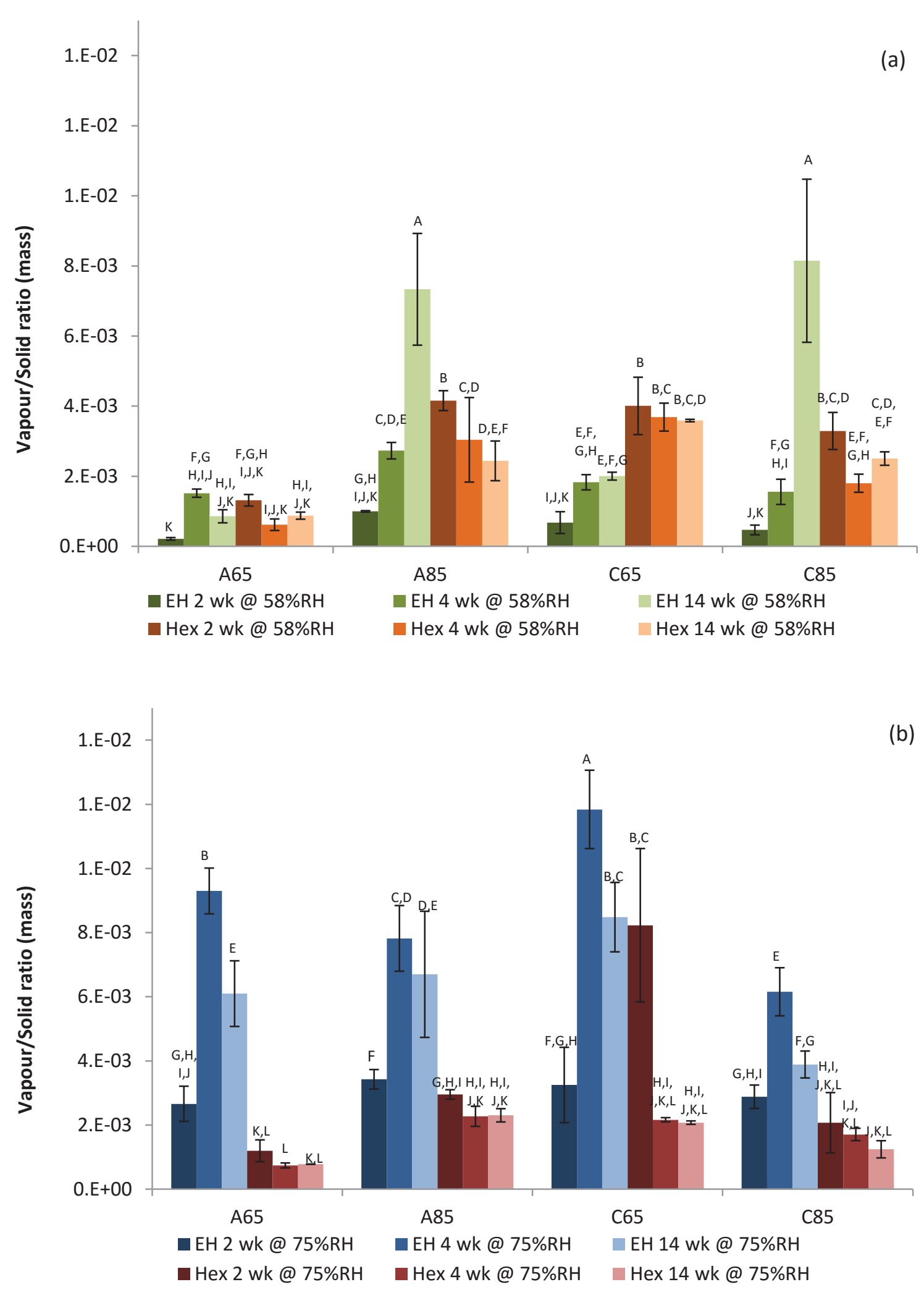

Figure 4-21a-b: Comparison of SPME vapour/solid ratio of samples after storage (a: $58 \% \mathrm{RH}$ and b: $75 \% \mathrm{RH})$. Different labels in capital letters ( $\mathrm{A}-\mathrm{K}$ and $\mathrm{A}-\mathrm{L}$ ) indicate significant difference $(P<0.001)$ at 95\% confidence interval by Fisher's LSD test. ANOVA tests were separately done per each \% RH. 
In order to facilitate comparison of SPME results between $58 \%$ and $75 \% \mathrm{RH}$, and additional figure is provided in Appendix 1 (Figure A-3). Ethyl hexanoate tended to release faster and more at higher humidity, possibly as a result of increased sub- $\mathrm{T}_{\mathrm{g}}$ molecular mobility, while no effect of relative humidity was observed for 2-hexanone. Ethyl hexanoate is poorly water soluble therefore it easily releases from the matrix then it was released faster and to a greater extent in all samples. 2-Hexanone is more soluble in water than ethyl hexanoate then it is less sensitive to the increasing hydration. The release of 2-hexanone slightly reduced but the trends of release suggested that there were no evolution of flavour release. Hence, it is important to further compare these results with structural evolution in order to clarify such an interaction between these 3 components.

Additional experiments were performed in order to understand the behaviour of flavours. It was interesting to see whether flavours release was still possible after 14 weeks of study. Therefore, the sample vials were opened and purged with nitrogen gas to remove all headspace air. After that, the vials were re-closed and left standing overnight prior to SPME analysis. Once the samples were subjected to SPME analysis, they were removed from the setting, and the saturated salt solution only was kept in the setting, its headspace was purged with nitrogen gas, the setting re-closed and left standing overnight before subjecting it to another SPME analysis. Figure 4-22 represents the SPME vapour/solid ratio of flavours in comparison for 3 study states: after 14 weeks, after purging and for the saturated salt solution above which the sample had been stored. The result of each flavour was separately displayed in Figure 4-22 a and b for ethyl hexanoate and 2-hexanone, respectively.

According to Figure 4-21, ethyl hexanoate was found at remarkable level after purge and even in the saturated salt solution whereas it was almost undetectable for 2hexanone (Appendix 1: Figure A-4). The amount of flavour released was calculated as percent ratio to the amount at 14 weeks (Appendix 1: Table A-1). Regarding the result of ethyl hexanoate after purging in sample C85, it is possible that experimental error occurred during analysis hence the content was very different compared to the other sample. Indeed the release level is as great after one night as after several weeks. The results of SPME after purging showed that there was 2-hexanone left in the headspace. Comparing the results after purging at $58 \%$ and $75 \% \mathrm{RH}$, the flavour contents at $58 \% \mathrm{RH}$ were lower in every sample. 
For 2-hexanone, there were 2 possible explanations. On the one hand, 2hexanone was totally released into air phase therefore there was no 2-hexanone left after purging. On the other hand, 2-hexanone possibly requires longer time than ethyl hexanoate to release once purging disturbed the system's equilibrium.

The result of SPME analysis of saturated salt solution suggested that ethyl hexanoate was partially trapped inside saturated salt solution. There is no precise literature data available to explain interaction between flavour and saturated salt. It remains unclear whether flavour only interacted with the water in the saturated salt or if it was a ternary interaction (flavour-water/ $\mathrm{NaCl}$ or $\mathrm{NaBr}$. Such interaction, retaining ethyl hexanoate with saturated salt solution is hypothesised to be due to microporous entrapment.

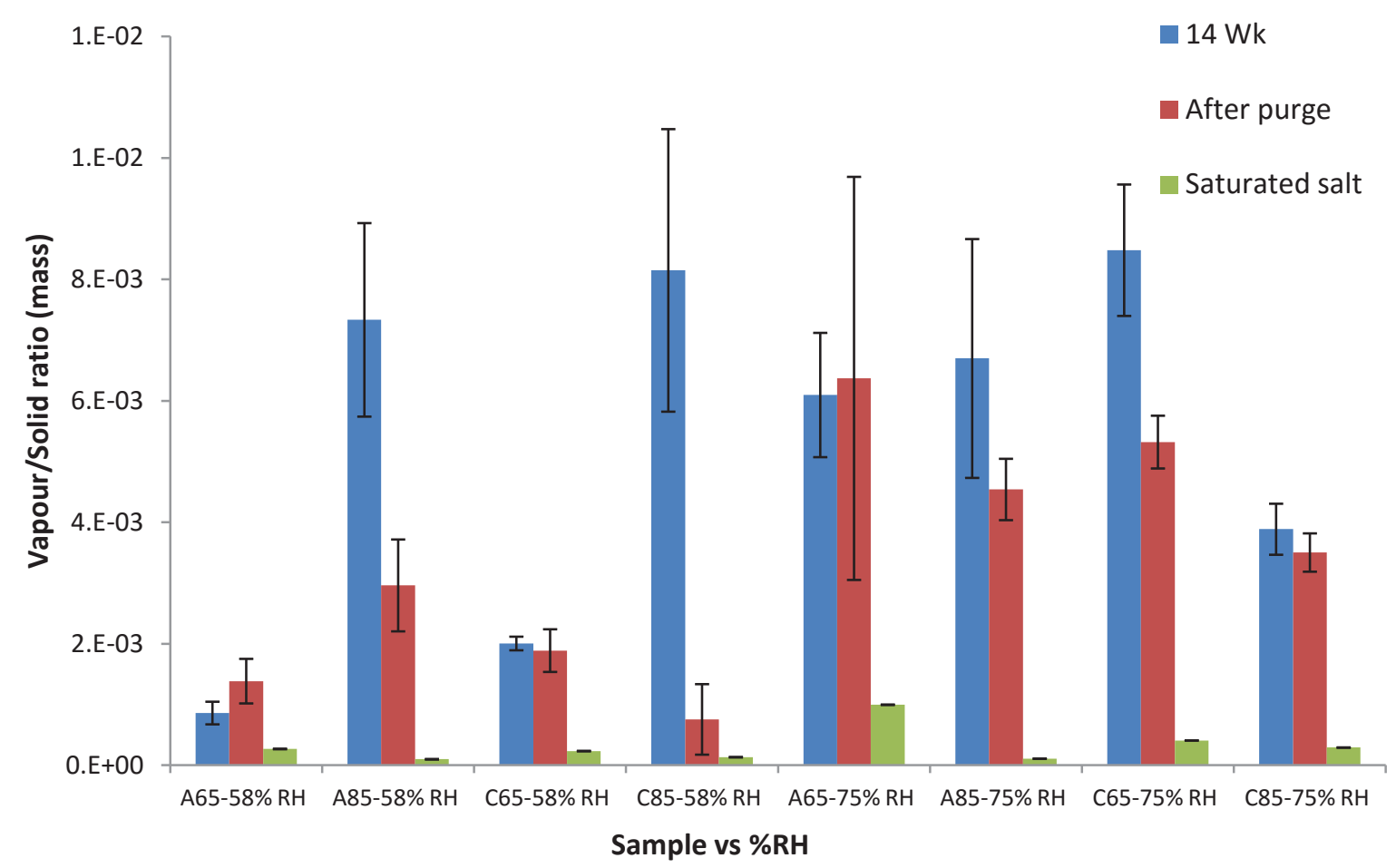

Figure 4-22a-b: Comparison of SPME vapour/solid ratio of ethyl hexanoate release after storage 14 weeks, after purge and in saturated salt solution

The overall results of SPME analysis of the sample after storage, after purging and of saturated salt solution can be explained by the model as shown in Figure 4-23. Ethyl hexanoate behaved differently from 2-hexanone. At 75\% RH, ethyl hexanoate was released and probably reached its equilibrium at 4 weeks storage (Figure 4-23a). The red arrows in 
Figure 4-23a represent mobility of ethyl hexanoate. At first (1), the flavour was released into the headspace and probably went back to the sample. At $58 \% \mathrm{RH}$, flavour release was slower, thus still in progress and the system may fluctuate before reaching its equilibrium, therefore the released amount of ethyl hexanoate continuously increased throughout study time as indicated by 2 red arrows with the same direction (Figure 4-23b). In case of 2hexanone, the flavour behaved similarly at both \%RHs. Most 2-hexanone was probably released at 2 weeks of storage and then remained constant as the system achieved its equilibrium (Figure 4-23c) and indicated by 2-way arrow. The amount of 2-hexanone remained unchanged. This is possible that released contents of 2-hexanone were small and lower than detection limit especially that 2-hexanone is more soluble in water than ethyl hexanoate.

(a)

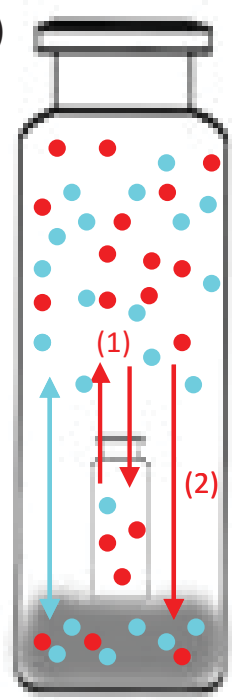

(b)

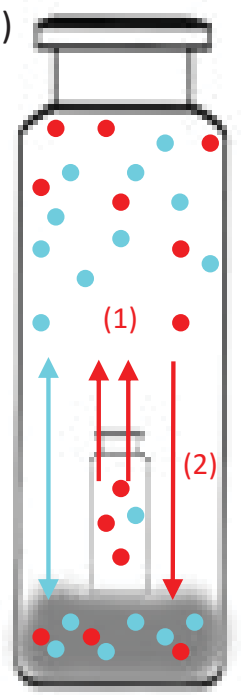

(c)

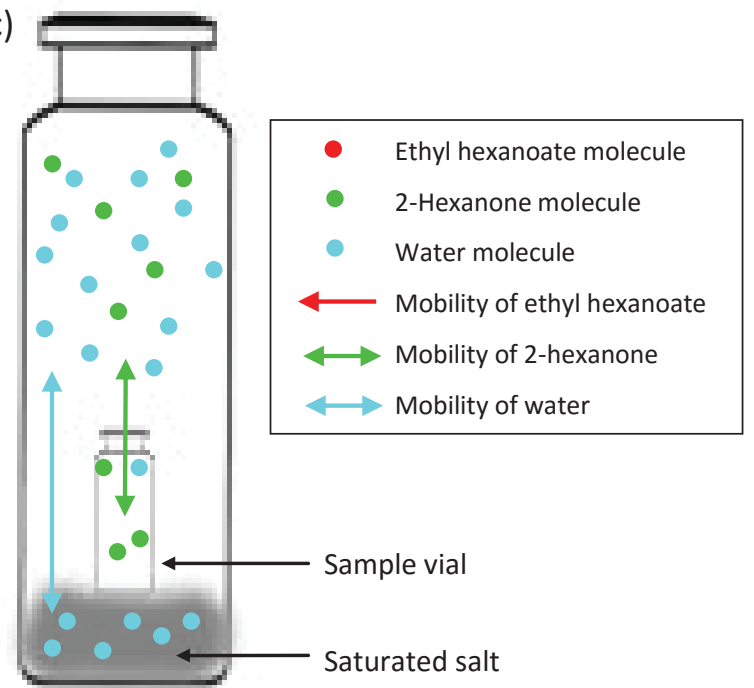

Figure 4-23a-b: Schematic represents flavour release and molecular mobility upon storage of ethyl hexanoate at $75 \% \mathrm{RH}(\mathrm{a})$, ethyl hexanoate at $58 \% \mathrm{RH}(\mathrm{b})$ and 2-hexanone at 75 and $58 \% \mathrm{RH}$ (c).

\section{Box 9: 4.2.1.1 Section highlight}

- The higher the humidity, the greater the release.

- Ethyl hexanoate was more released than 2-hexanone

- The released ethyl hexanoate was partially trapped in saturated salt solution phase. 


\subsubsection{Flavour retention study by simultaneous distillation extraction (Likens-}

\section{Nickerson extraction)}

This is a parallel study to SPME analysis. A portion of each freeze-dried sample stored in controlled relative humidity atmosphere (58 and $75 \% \mathrm{RH}$ ). Each sample was divided into 3 portions (3 sampling times: 2, 4, 14 weeks) and stored separately to avoid opening-closing the container. At each time point they were subjected to Likens-Nickerson extraction in order to assay the flavour content in the sample upon storage. Although SPME and Lickens Nickerson experiments are different in scale and probably incomparable, they demonstrated flavour stability at different dimension.

Residual content of ethyl hexanoate after storage at 58\% $\mathrm{RH}$ was reported in Table 4-8. It was found that C85 lost 38\% of its initial content followed by A65 (19.9\%), C65 (5.4\%) and A85 (3.6\%). The result of C85 is coherent with its SPME counterpart in which C85 showed the highest released content. It is interesting to compare the results between A65 and A85, these 2 samples had similar \% crystallinity (by XRD) but flavour retention behaviour were completely different. Their difference could possibly be due to other factors such as, structure and granule properties. The previous results suggested that A65 granules were larger in size due to a possible greater swelling. The larger surface area probably induced higher release.

Table 4-8: Ethyl hexanoate residual by Likens-Nickerson extraction after storage at $58 \% \mathrm{RH}$

\begin{tabular}{ccccc}
\hline & \multicolumn{4}{c}{ Residual flavour (mg/g dry weight) } \\
\cline { 2 - 5 } Time (Weeks) & A65 & A85 & C65 & C85 \\
\hline 0 & $1.53 \pm 0.09^{\mathrm{A}}$ & $0.30 \pm 0.09^{\mathrm{B}}$ & $1.12 \pm 0.39^{\mathrm{B}, \mathrm{C}}$ & $1.13 \pm 0.25^{\mathrm{A}}$ \\
2 & $1.47 \pm 0.12^{\mathrm{A}, \mathrm{B}}$ & $0.43 \pm 0.02^{\mathrm{A}}$ & $1.26 \pm 0.08^{\mathrm{A}, \mathrm{B}}$ & $0.82 \pm 0.11^{\mathrm{A}}$ \\
4 & $1.48 \pm 0.30^{\mathrm{A}}$ & $0.44 \pm 0.03^{\mathrm{A}}$ & $1.28 \pm 0.13^{\mathrm{A}}$ & $1.11 \pm 0.40^{\mathrm{A}}$ \\
14 & $1.23 \pm 0.05^{\mathrm{B}}$ & $0.29 \pm 0.01^{\mathrm{B}}$ & $1.06 \pm 0.02^{\mathrm{C}}$ & $0.70 \pm 0.10^{\mathrm{A}}$ \\
\hline
\end{tabular}

Different labels in capital letters (superscript) indicate significant difference among each storage time. The significant tests were separately analysed on each sample at 95\% confidence interval by Fisher LSD test.

C65 is approximately two times greater in \% crystallinity than C85 but similar in granule size. The different release behaviour and flavour stability might be due to their crystallinities. 
Table 4-9: Ethyl hexanoate residual by Likens-Nickerson extraction after storage at $75 \% \mathrm{RH}$

\begin{tabular}{ccccc}
\hline & \multicolumn{4}{c}{ Residual flavour (mg/g dry weight) } \\
\cline { 2 - 5 } Time (Weeks) & A65 & A85 & C65 & C85 \\
\hline 0 & $1.53 \pm 0.09^{\mathrm{B}}$ & $0.30 \pm 0.09^{\mathrm{A}}$ & $1.12 \pm 0.39^{\mathrm{B}}$ & $1.13 \pm 0.25^{\mathrm{A}}$ \\
2 & $1.53 \pm 0.13^{\mathrm{B}}$ & $0.20 \pm 0.06^{\mathrm{B}}$ & $1.13 \pm 0.07^{\mathrm{B}}$ & $0.79 \pm 0.23^{\mathrm{B}}$ \\
4 & $1.77 \pm 0.08^{\mathrm{A}}$ & $0.31 \pm 0.03^{\mathrm{A}}$ & $1.39 \pm 0.18^{\mathrm{A}}$ & $0.79 \pm 0.06^{\mathrm{B}}$ \\
14 & $1.23 \pm 0.06^{\mathrm{C}}$ & $0.21 \pm 0.05^{\mathrm{B}}$ & $0.87 \pm 0.05^{\mathrm{C}}$ & $0.64 \pm 0.02^{\mathrm{B}}$ \\
\hline Loss over 14 weeks (\%) & $\mathbf{1 9 . 6}$ & $\mathbf{3 2 . 2}$ & $\mathbf{2 2 . 3}$ & $\mathbf{4 3 . 2}$ \\
\hline
\end{tabular}

Different labels in capital letters (superscript) indicate significant difference among each storage time. The significance tests were separately analysed on each sample at $95 \%$ confidence interval by Fisher LSD test.

Table 4-9 represented residual of ethyl hexanoate after storage at $75 \% \mathrm{RH}$. The result of flavour loss of $\mathrm{A} 65$ and $\mathrm{C} 85$ at $75 \% \mathrm{RH}$ were very similar to the ones at $58 \% \mathrm{RH}$ whereas A85 and C65 greatly increased in percent of flavour lost upon increasing of \%RH. In all samples, it is clear that \% flavour loss was driven by water.

Table 4-10: 2-Hexanone residual by Likens-Nickerson extraction after storage at 58\% $\mathrm{RH}$

\begin{tabular}{ccccc}
\hline & \multicolumn{4}{c}{ Residual flavour (mg/g dry weight) } \\
\cline { 2 - 5 } Time (Weeks) & A65 & A85 & C65 & C85 \\
\hline 0 & $21.80 \pm 0.98^{\mathrm{A}}$ & $3.45 \pm 0.06^{\mathrm{A}}$ & $2.54 \pm 0.17^{\mathrm{A}}$ & $5.50 \pm 0.40^{\mathrm{B}}$ \\
2 & $17.99 \pm 0.56^{\mathrm{B}}$ & $3.10 \pm 0.25^{\mathrm{B}}$ & $1.69 \pm 0.19^{\mathrm{B}}$ & $4.64 \pm 0.21^{\mathrm{C}}$ \\
4 & $19.32 \pm 2.77^{\mathrm{A}, \mathrm{B}}$ & $3.40 \pm 0.35^{\mathrm{A}}$ & $2.41 \pm 0.64^{\mathrm{A}}$ & $6.61 \pm 0.63^{\mathrm{A}}$ \\
14 & $19.53 \pm 2.70^{\mathrm{A}, \mathrm{B}}$ & $3.35 \pm 0.22^{\mathrm{A}, \mathrm{B}}$ & $1.83 \pm 0.19^{\mathrm{B}}$ & $4.30 \pm 0.08^{\mathrm{C}}$ \\
\hline Loss over 14 weeks (\%) & $\mathbf{1 0 . 4}$ & $\mathbf{2 . 8}$ & $\mathbf{2 8 . 1}$ & $\mathbf{2 1 . 7}$
\end{tabular}

Different labels in capital letters (superscript) indicate significant difference among each storage time. The significant tests were separately analysed on each sample at $95 \%$ confidence interval by Fisher LSD test.

Table 4-10 represented residual of 2-hexanone after storage at 58\% RH. C65 was found to have the highest percent of flavour loss $(28.1 \%)$ but still similar to $C 85(21.7 \%)$ while $A 65$ lost $10.4 \%$ and A85 only lost 2.8\% after 14 weeks of storage. Regarding A65 and A85, the difference in \% flavour loss might be due to difference in their structure as mentioned before. Compared to ethyl hexanoate at $58 \% \mathrm{RH}$, the loss of 2-hexanone was slower for C85. It is possible that 2-hexanone was better interacting with C85 and the flavour better integrated since it had less crystallinity than C65. The smaller \% crystallinity represents less order of starch structure which could allow flavour to access and interact with starch. 
Table 4-11: 2-Hexanone residual by Likens-Nickerson extraction after storage at $75 \% \mathrm{RH}$

\begin{tabular}{ccccc}
\hline & \multicolumn{4}{c}{ Residual flavour (mg/g dry weight) } \\
\cline { 2 - 5 } Time (Weeks) & A65 & A85 & C65 & C85 \\
\hline 0 & $21.80 \pm 0.98^{\mathrm{A}}$ & $3.45 \pm 0.06^{\mathrm{A}}$ & $2.54 \pm 0.17^{\mathrm{A}}$ & $5.50 \pm 0.39^{\mathrm{A}}$ \\
2 & $7.73 \pm 0.43^{\mathrm{B}}$ & $0.90 \pm 0.10^{\mathrm{B}}$ & $0.29 \pm 0.04^{\mathrm{B}}$ & $1.62 \pm 0.15^{\mathrm{B}}$ \\
4 & $9.30 \pm 2.34^{\mathrm{B}}$ & $0.62 \pm 0.03^{\mathrm{C}}$ & $0.22 \pm 0.14^{\mathrm{B}}$ & $1.77 \pm 0.11^{\mathrm{B}}$ \\
14 & $5.68 \pm 1.74^{\mathrm{C}}$ & $0.36 \pm 0.16^{\mathrm{D}}$ & ND $^{\mathrm{C}}$ & $0.86 \pm 0.13^{\mathrm{C}}$ \\
\hline Loss over 14 weeks (\%) & $\mathbf{7 4 . 0}$ & $\mathbf{8 9 . 5}$ & $\mathbf{1 0 0 . 0}$ & $\mathbf{8 4 . 3}$ \\
\hline
\end{tabular}

Different labels in capital letters (superscript) indicate significant difference among each storage time. The significant tests were separately analysed on each sample at $95 \%$ confidence interval by Fisher LSD test. ND: Not detectable

Residual of 2-hexanone after 14 weeks storage at 75\% RH are shown in Table 411. It was found that the extracted amount of 2-hexanone dramatically decreased when relative humidity increased for all samples by sharply declining at 2 weeks of storage. After that, 2-hexanone content continuously decreased. It was found that C65 totally lost its 2hexanone content after 14 weeks which is the maximum loss among 4 samples. It is emphasised that C65 was greatly affected by water content and at one point it completely lost its stability. 2-Hexanone was found to be most retained in $\mathrm{A} 85$ at $58 \% \mathrm{RH}$, however the behaviour changed when \% RH was raised to 75\%. Regarding to A65 and C85, they showed smaller loss than A85 and C65. It is possible that they started to lose flavour faster (at 58\% $\mathrm{RH}$ ) and progressively lost therefore the loss rates were slightly smaller. The most probable explanation to the phenomenon of 2-hexanone loss upon storage is that the samples possessed certain capacity to uptake the water into their structures. Once they achieved their water uptaking limit, their flavour could no longer stay within the starch systems which resulted in the dramatically loss.

Ethyl hexanoate is known to be able to form flavour inclusion complex with starch. This complex is believed to retain and limit release of ethyl hexanoate (Arvisenet, et al., 2002; Pozo-Bayon, et al., 2008). However, the actual formation of inclusion complex in these samples remains unclear. The behaviour of ethyl hexanoate may change depending on the conditions. The overall result at $58 \% \mathrm{RH}$ suggested that 2-hexanone is more stable than ethyl hexanoate but it is opposite when \%RH was increased to $75 \%$. Since we were unable to indicate the location of flavour within the granule, it is difficult to explain how starch structure stabilises or helps protect the flavour that bound to it. Moreover, each 
sample containing different structural feature therefore they behaved differently. Another bearable point is starch granules of each sample contained uneven parts. The adjacent area and contact point between different structural parts may trigger different interactions. According to the result of storage study, it can be implied that $58 \%$ is an initial point of chemical alteration in the studied samples. The samples need to be stored at lower humidity in order to keep their flavour stabilities. It was suggested that flavour inclusion complex are stable at room temperature and water activity below 0.5. This storage conditions are suggested to prevent evaporation and oxidation of flavour compounds (Wulff, et al., 2005). To study this, variation of \% $\mathrm{RH}$ and temperature of storage are required in order to find-out the specific point.

Comparing the results of 2 parallel studies, SPME and flavour extraction, it was found that flavour release was greater in $75 \% \mathrm{RH}$ for both studies. The greatly loss upon storage in extraction study was due sample equilibration from 0-2 weeks and continue throughout the study. This loss during week 0-2 cannot be distinguished by SPME study therefore the release in SPME tests seemed smaller. The result of SPME suggested that 2hexanone is better retained in the sample while extraction showed that it was greater released than ethyl hexanoate. These contrasted results were due to the fact that 2hexanone contents were dramatically decreased during week $0-2$, then remained constant during week 2-4 and finally reduced at week 14. Comparing the study scales between SPME and extraction, this could be another reason that 2-hexanone showed greater loss because the quantification limit of extraction is a lot greater than SPME. A small change in flavour content could affect extraction content.

\section{Box 10: 4.2.1.2 Section highlight}

- Flavour residual contents were greatly reduced during the first 2 weeks of sample equilibration. After that, the trends of loss seem to be more stable.

- 2-Hexanone was found to have greater loss at 75\% RH than ethyl hexanoate but it might be due to low residual content which might be lower than quantification limit.

- The higher the humidity, the greater flavour loss. 


\subsubsection{Structural evolution upon storage (enthalpy of relaxation)}

Three vials of each sample from SPME analysis were taken to DSC analysis. Example of DSC thermograms obtained from after storage are shown in Figure 4-24. Enthalpy of relaxation was obtained from the first heating scan. Figure 4-24, demonstrated the evolution of enthalpy relaxation of sample A85 upon storage. At initial state ( 0 week), no enthalpy relaxation was observed through an overshoot of the $\Delta \mathrm{H}$, and it had started to be seen more clearly after 2 weeks of storage.

Enthalpies of relaxation versus storage time are shown in Figure 4-25. Figure 4-25a, b, c, and d represented the results of sample A65s, A85s, C65s and C85s at 58\% and 75\% RH, respectively. According to Figure 4-25a, there is no effect of relative humidity on the relaxation enthalpies. A facilitated relaxation may have been expected for the samples stored at $75 \% \mathrm{RH}$ thus closer to their $\mathrm{Tg}$ while at $25^{\circ} \mathrm{C}$ since increased molecular mobility is known to facilitate the structural relaxation (Borde, Bizot, Vigier, \& Buleon, 2002). The difference in distance to $\operatorname{Tg}\left(\operatorname{Tg} \_25^{\circ} \mathrm{C}\right)$ might be too limited to modify the relaxation pattern of the hydration levels.

The general trend is an increase of relaxation enthalpy with storage time in agreement with literature (Chung \& Lim, 2003b). Among the 3 samples of A65, it was found that the relaxation enthalpies increased faster in A65Hex C2 than the other samples at 2 weeks in both \%RHs, then the enthalpies slightly increased at 4 weeks and seemed to stabilise until 14 weeks. This is opposite to $\mathrm{A} 65$ at $75 \% \mathrm{RH}$ which relaxed enthalpy slowly increased until 4 weeks and then stabilise till the end of study. $\mathrm{A} 65 \mathrm{EH}$ at $75 \% \mathrm{RH}$ exhibited a relaxation enthalpy at 2 weeks storage increasing faster than at $58 \% \mathrm{RH}$ and finally the sample gained its maximum at the same rate. The overall results of sample A85s were very similar to the results of A65s except enthalpies increased in the sharper rates and the relaxed enthalpies were higher at 2 weeks. It is interesting for sample A85EH since its relaxed enthalpy at 75\% $\mathrm{RH}$ was higher than at $58 \%$ which is different from other results.

C65Hex $\mathrm{C} 2$ fast increased in relaxed enthalpy at $58 \% \mathrm{RH}$ while it remained similar to other samples at $75 \% \mathrm{RH}$. It was found that $\mathrm{C65EH}$ had the higher relaxed enthalpy at $75 \%$ $\mathrm{RH}$ than at 58\% RH throughout study. $\mathrm{C} 85$ samples seemed to relax enthalpies at similar rate during 2 weeks of storage. After that, relaxed enthalpies of C85Hex C2 continued to increase at 4 weeks (both \%RHs) and then stabilised until 14 weeks. C85s seemed to have similar relaxed enthalpies at $58 \%$ and $75 \% \mathrm{RH}$ until 4 weeks storage, then they both continued to 
increase and finally C85 at 58\% had higher relaxed enthalpy at 14 weeks. Relaxed enthalpies of $\mathrm{C} 85 \mathrm{EH}$ were similar at 2 weeks but the value at $75 \% \mathrm{RH}$ was found to be higher. The relaxation enthalpies at both $\% \mathrm{RH}$ continued to increase until 14 weeks but their final relaxed enthalpies were not significantly different.

The overall image of relaxed enthalpies suggested that each sample was different from each other. Comparing sample with/without flavour, it could be implied that the samples were affected by flavour addition since they had a similar \% crystallinity but their abilities to relax were different. It is also emphasised the hypothesis that they were different in crystal properties. Sample A65 and A85 are similar in crystallinity but their other properties e.g. RVA pasting profile, granule size, flavour release were different. It is possible that some samples were not yet at their maximum relaxation since the trend lines were not yet stable.

There is a common characteristic among samples containing 2-hexanone that they were similar in flavour release profile (SPME) and relaxation ability. 2-Hexanone was found to have greater release at $58 \% \mathrm{RH}$ as well as greater in relaxed enthalpies at $58 \% \mathrm{RH}$. Considering the trends of residual contents of ethyl hexanoate at $58 \%$ and $75 \% \mathrm{RH}$ in SPME study, it was found that the flavour was released in remarkable amount at $75 \% \mathrm{RH}$ throughout storage time while A85 and C65 only markedly released 14 weeks for both \%RHs. The overall trends suggested that samples containing ethyl hexanoate had the highest relaxation at $75 \% \mathrm{RH}$ as well as greater flavour release.

The result of SMPE showed that 2-hexanone was retained upon storage. As the sample absorbed the water into its structure, the enthalpy relaxation increased, the absorbed water helped stabilise and retain 2-hexanone. On the contrary, starch containing ethyl hexanoate absorbed water into its structure and drove away ethyl hexanoate. It is possible to say that the greater structural relaxation the greater in flavour release. It is possible that the starch tried to stabilise itself and responded to higher mobility upon storage. Therefore, the flavours were released as a result of relaxation in order to stabilise the the starch structure. Thanks to a greater mobility, the samples reorganised their structure through a structural relaxation thus a densification of its structure, through which the flavour was expelled. It could be implied that starch uptook water upon storage into its structure and it disturbed the interaction between starch and ethyl hexanoate. Since ethyl hexanoate is poorly soluble in water, hence it was released. 
There are several ways for polysaccharides to bind to volatile compounds: hydrogen bonding between appropriate functional groups, non-covalent bonding (small flavour molecule), and hydrophobic interaction, (Conde-Petit, et al., 2006; Harrison \& Hills, 1997; Heinemann, et al., 2005; Kersiene, Adams, Dubra, Kimpe, \& Leskauskaite-, 2008) . Binding capacity is a factor controlling flavour release (Harrison \& Hills, 1997). Binding capacity probably changed upon storage and humidified. Water became more competitive in starch binding. Structural relaxation enhanced water binding rather than ethyl hexanoate. It was found that starch that formed inclusion complex with fatty acid relaxes faster than the free one.

\section{Box 11: 4.2.1.2 Section highlight}

- The sample containing 2-hexanone demonstrated the highest enthalpy relaxation at 2 weeks storage $(58 \% \mathrm{RH})$ whereas sample containing ethyl hexanoate had smaller enthalpy relaxation at 2 weeks.

- There was no significant different of enthalpy relaxation at 14 weeks.

- The greater release, the greater relaxation. The greater release was a consequence of mobility increasing. 


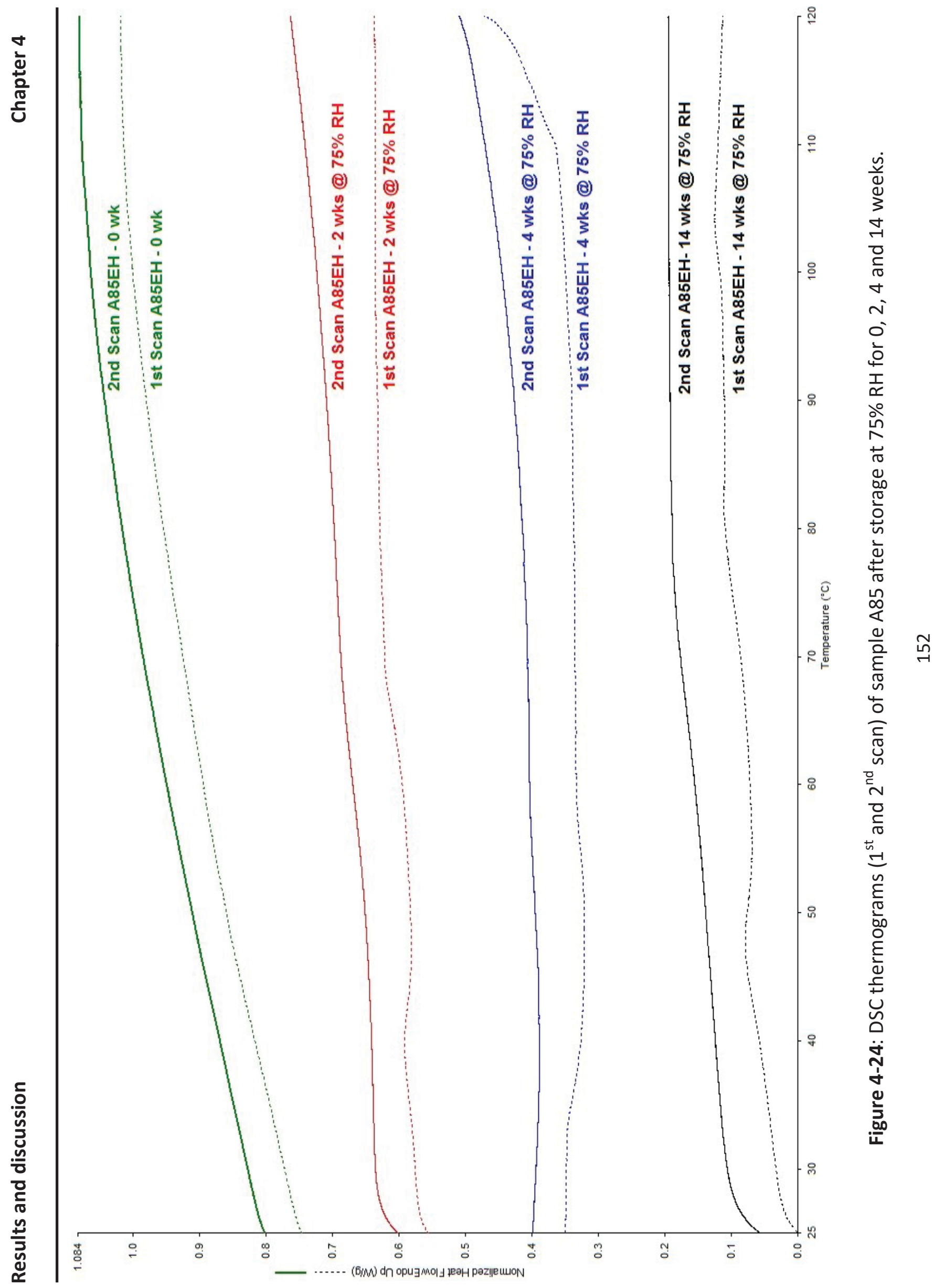




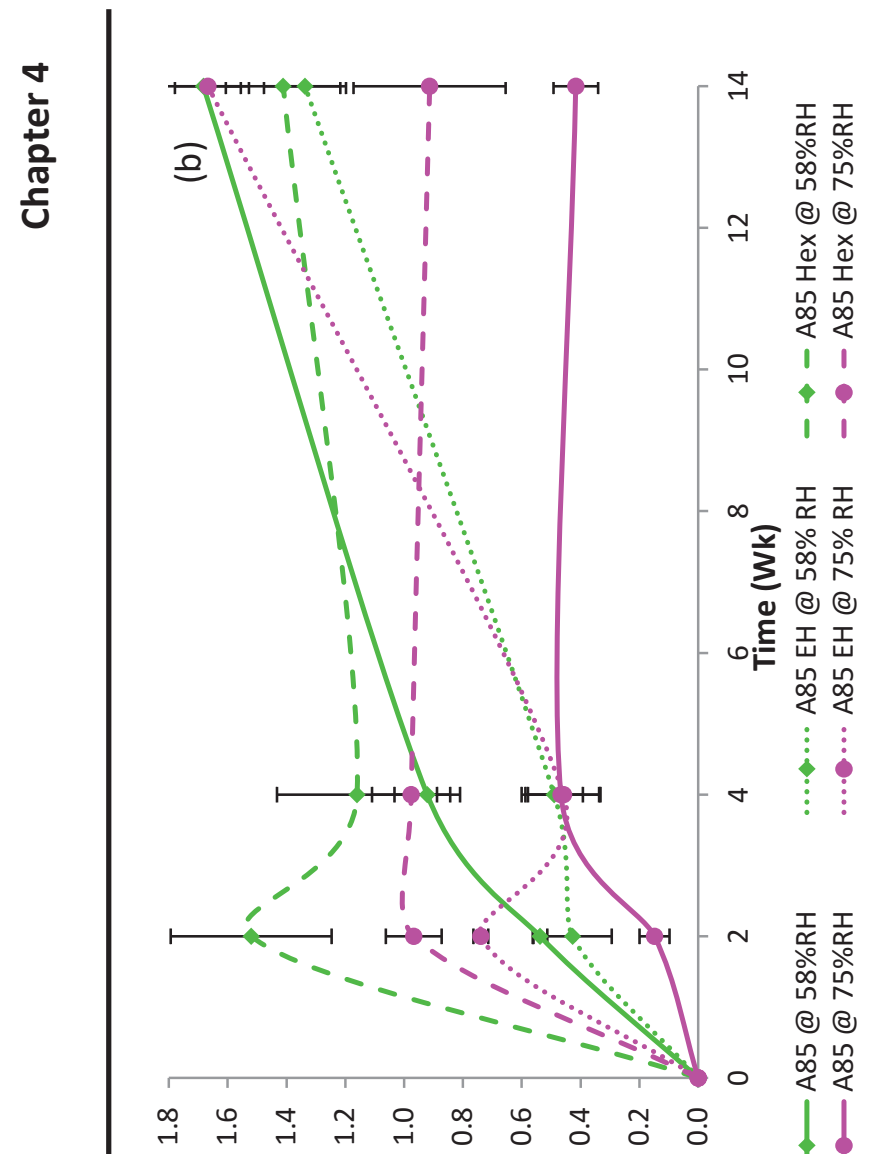

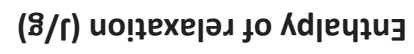

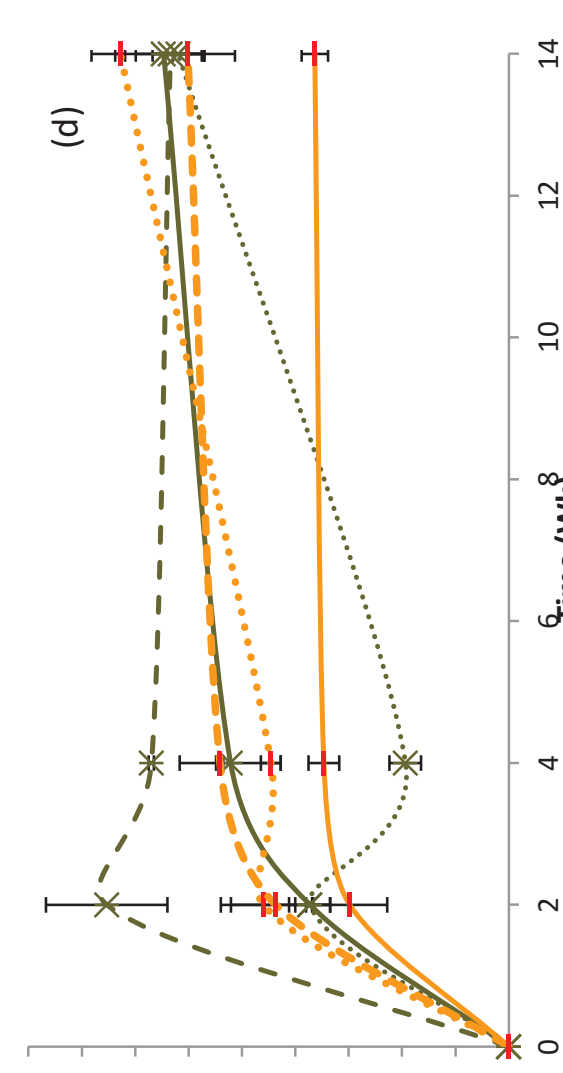

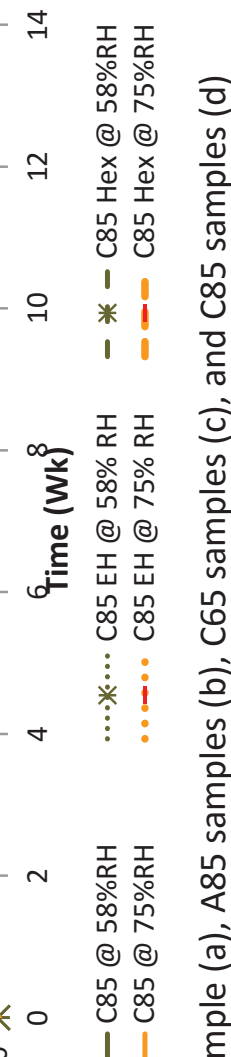

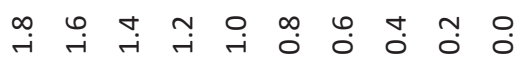

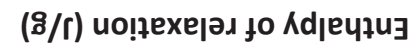
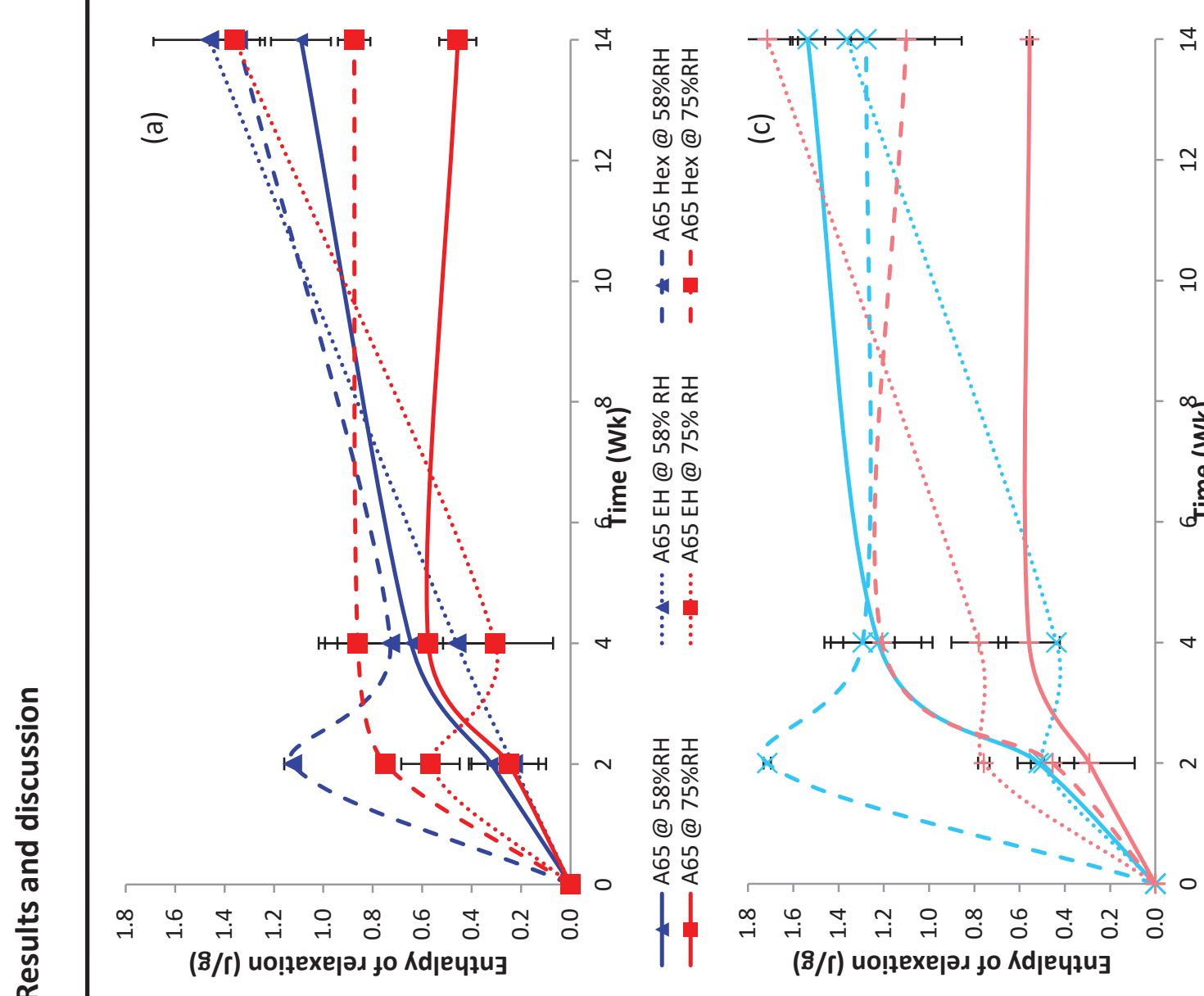

$\stackrel{n}{\leftrightarrow}$

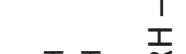

I

ò ㅇํㅇ ํํํ

ㄱ (8) (8) 응

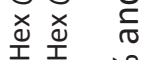

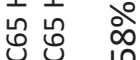

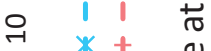

11

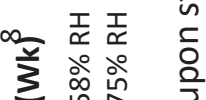

(ะ) (8)

है

过雚 $\frac{⿱ 亠 乂}{0}$

$\dot{x}+4$

$\therefore \frac{\text { वे }}{\vdots}$

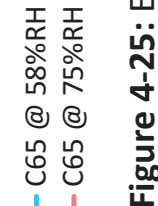

(8/r) uo!̣exe|әд jo Кdןечұu 


\subsection{Structural and flavour analysis by FTIR (Trial approach)}

This part of experiment was done as a trial approach. According to Fanta et al. (1999) and Bias et al. (2006), FTIR technique was proved to be able to detect flavour inclusion complex as well as quantification of flavour content. The results of DSC and structural analysis (XRD and WAXS) demonstrated that no flavour inclusion complex could be detected. However, it is interesting to see whether it is possible to detect them by FTIR technique. In this study, no cleaning (removing non-complexed flavour) treatment was applied to the samples as they contained very low residual flavour. Figure 4-26a-d and Figure 4-27a-d represent FTIR spectra with their derivative analysis. Derivative analysis is a data treatment technique applied for trace element analysis in FTIR.

Regarding the FTIR spectrum at 1200 and $1000 \mathrm{~cm}^{-1}$, they correspond to stretching of $\mathrm{C}-\mathrm{OH}$ and $\mathrm{C}-\mathrm{O}-\mathrm{C}$ bonds. In this region, it also represents starch fingerprint. Infrared band at $1739 \mathrm{~cm}-1$ and at $1444 \mathrm{~cm}-1$ are the stretch vibrations of $\mathrm{C}=\mathrm{O}$ and $\mathrm{C}-\mathrm{H}$, respectively. These are distinctive characteristics in organic ester compounds which were used as the mark of flavour-inclusion complex in the study of Bias et al. (2006). Infrared spectrum of aldehyde and ketone group were at $1710-1750 \mathrm{~cm}^{-1}$ which is the case of 2-hexanone that contains $\mathrm{C}=\mathrm{O}$.

Flavour inclusion complex could not be detected within the samples, according to the obtained spectra in Figure 4-26 and Figure 4-27 suggested. However, derivative analysis helped increasing the resolution of spectra and there were spectra on which functional group corresponding to flavour compounds were detected.

The result of this study suggested that FTIR can be applied as a screening method during sample preparation as it is more sensitive than DSC analysis. Flavour extraction has an advantage interm of flavour quantity and complex formation, however it is time consuming compared to FTIR which may also provide information on the structure. This would help optimising the method of study. Considering flavour inclusion complex study, sample cleaning by mean of removal non-complexing flavour is required together with XRD or WAXS analysis for flavour localisation and quantification (Bias et al., 2006).

In addition to application of FTIR, it can be combined with other technique for determination of relative crystallinity, structural changes (Flores-Morales, et al., 2012; Smits, et al., 1998; Y. Sun, et al., 2014). The band at $1300-800 \mathrm{~cm}^{-1}$ region corresponded to vibration associated with $\mathrm{C}-\mathrm{C}$ and $\mathrm{C}-\mathrm{O}$ bonds and sensitive to change in starch polymer 
conformation (Y. Sun, et al., 2014). Hence, this region is suitable for relative crystallinity study. The amorphous regions of starch can be associated with the band at $1600 \mathrm{~cm}^{-1}$ (Flores-Morales, et al., 2012). The band at $1500 \mathrm{~cm}^{-1}$ associated to the skeletal mode vibration of $\alpha-1,4$ glycoside linkages (C-O-C) while the bands at 1022 and $850 \mathrm{~cm}^{-1}$ are sensitive to change in crystallinity. The band at $1047 \mathrm{~cm}^{-1}$ is a characteristic of more organised part of starch while $1022 \mathrm{~cm}^{-1}$ is of amorphous starch. The band at $995 \mathrm{~cm}^{-1}$ is sensitive to water (Smits, et al., 1998).

Regarding the applications of FTIR as above mentioned, it seems to be a promising technique since it can be applied for both flavour and structural studies. It could reduce data treatments and conflicts of study scale. 

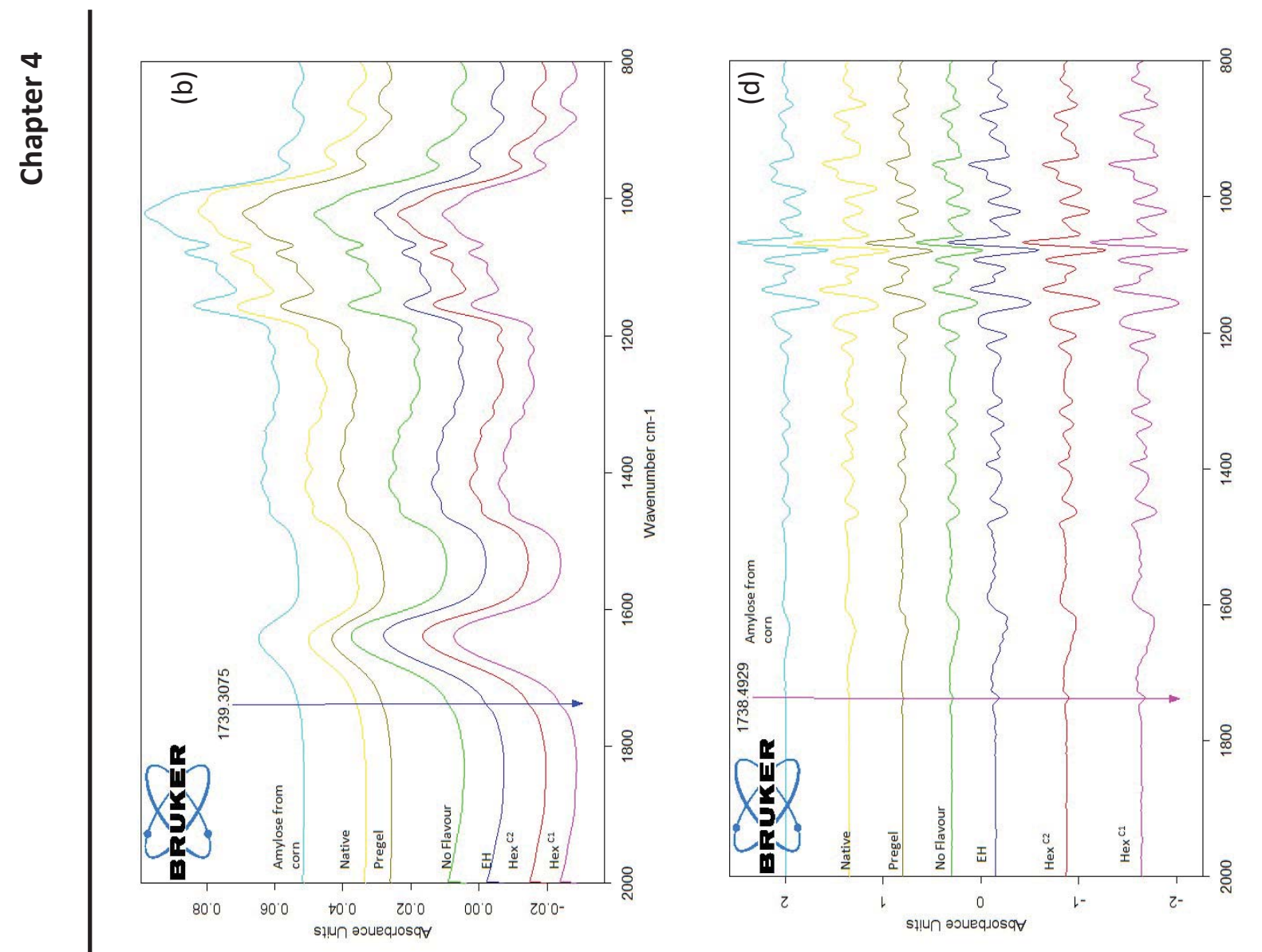

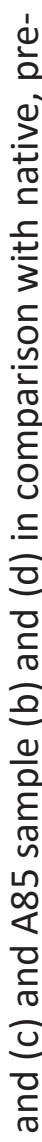
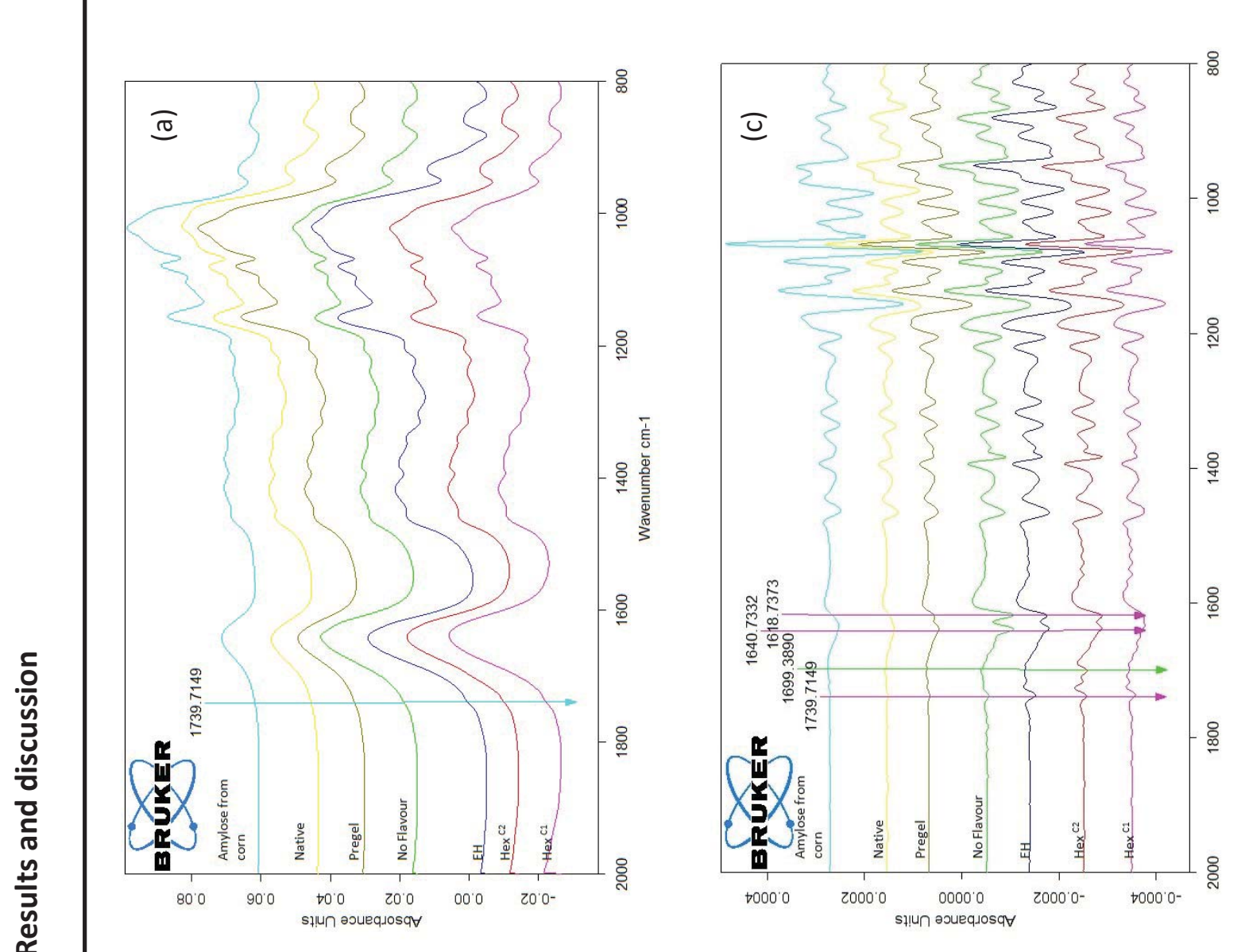

$\stackrel{\circ}{\circ}$

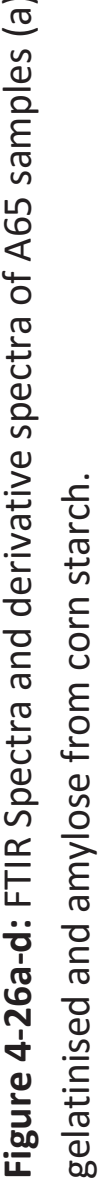




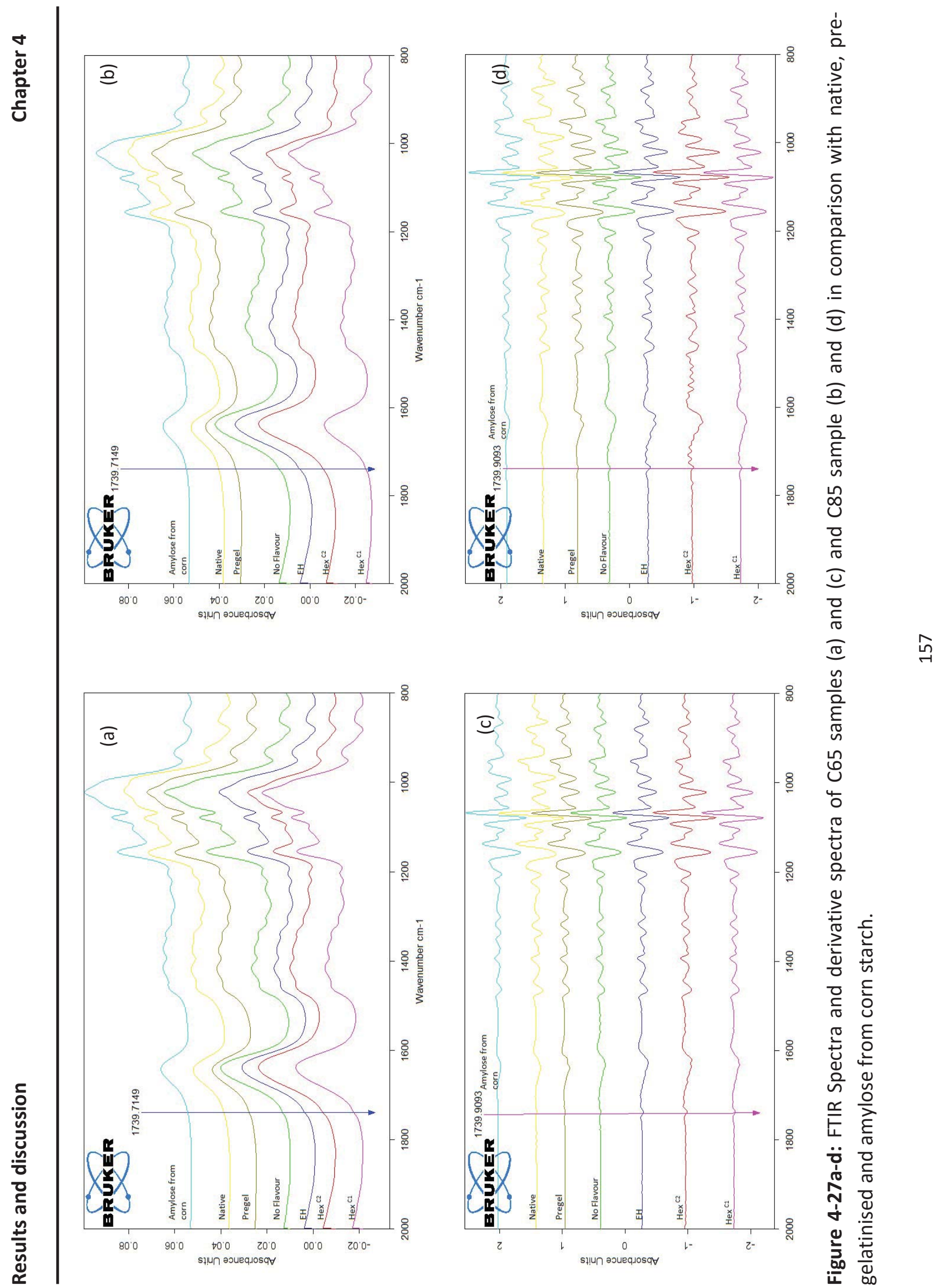


Chapter 5: General discussion 
According to the objectives of this study, the discussion can be divided into 2 aspects: effect of hydrothermal treatment and starch-flavour interaction versus physical state. The first point to discuss concerns effect of hydrothermal treatment on: flavour interaction, rheology and structural changes. The second aspect concerns: flavour retention and release and structural relaxation. In order to facilitate the discussion, some of key results were summarised in Table 5-1.

\subsection{Effect of hydrothermal treatment}

\subsubsection{Flavour interaction}

According to literature data, mostly suggested that suitable flavour such as ethyl hexanoate is able to form inclusion complex with starch upon gelatinisation (Pozo-Bayon, et al., 2008) . Some suggested that 2-hexanone is unable to form inclusion complex (Jouquand, et al., 2006) while another said it is able to form complex with slightly low complex index (Waigh, et al., 2000). Although the available results of the present study cannot clearly identify the formation of such complex, they demonstrated and proved that flavour could interact with starch under moderated heat and limiting water conditions. The occurred interactions were strong enough to retain the flavour within starch and the resulted products were stable upon freeze-drying and storage study. Regarding 2-hexanone, this study proved that it is able to interact with starch in similar manner comparing to ethyl hexanoate (Table 5-1). This finding is opposite to Jouquand et al. (2006) which possibly due to sample preparation conditions.

Gelatinisation facilitates uncoiling of amylose helices and allows ligand molecules to get inside, be trapped and then inclusion complex could form (Pozo-Bayon, et al., 2008). After gelatinisation and cooling, recrystallisation occurs (Pozo-Bayon, et al., 2008)). Therefore inclusion complex can be detected by X-ray diffraction. In this study, the samples were frozen after preparation and cooled to room temperature to prevent retrogradation. The sample preparation conditions may not suitable or limit co-crystallisation of flavourinclusion

According to the literature data, binding plays an important role in starch-flavour interaction (Le Thanh, et al., 1992). Hence, the interaction that occurred within the resulting samples can be considered as binding interaction as well. Further study could involve localisation of interacting flavour since there were such interaction but the inclusion 
complexes were undetectable. For this study, the localisations of residual flavour remain unclear. The results of WAXS showed increasing peak intensity at some areas represent complex formation (Jouquand et al., 2006; Le Bail, 2005; Rondeau-Mouro, et al., 2004). The peaks were not really enough which according to the structure may correspond to starch that was not completely gelatinised (and still similar to native crystal). However, the results of WAXS were promising. The comparison study by varying heating temperature and flavour concentration could help identify the localisation of flavour. FTIR is another interesting technique to develop for detection of inclusion complex or starch-flavour interaction.

Based on residual flavour contents, hydrothermal treatment affected on starchflavour interaction in 2 different ways. At high hydration, temperature plays an important role on water and flavour vaporisation therefore caused high flavour loss. At low hydration, there was no significant effect of heating temperature on flavour loss except for 2-hexanone C2. The huge flavour loss from C65 with 2-hexanone C2 could be due to heating temperature which was too low to allow amylose/amylopectin uncoiling and crystal melting and finally prevented flavour to penetrate into starch structure and immobilise there. At 65 ${ }^{\circ} \mathrm{C}$, 2-hexanone could probably better stay in flavour phase than at $85^{\circ} \mathrm{C}$. Since starch and water took longer time to interact, this could let 2-hexanone vaporise at a higher rate. At 85 ${ }^{\circ} \mathrm{C}$, temperature was high enough to allow amylose/amylopectin uncoiling and this process occurred faster and better than at $65^{\circ} \mathrm{C}$. This hypothesis is in accordance with the results of structural analysis (DSC, XRD, WAXS and SAXS) that C65 samples contained higher residual native and residual crystallinity and SAXS showed that the crystalline layers of C65 samples were not totally disrupted. This suggested though 2-hexanone quantity was increased, the conditions of 665 cannot promote higher flavour interaction due to organic phase separation.

\subsubsection{Rheology and structure (Granular and sub-granular levels)}

The difference observed in RVA pasting profile and granule size of two sample groups ( $A$ and $C$ ) were due to degree of swelling. Swelling power has been correlated with pasting characteristics of wheat starch (Blazek \& Copeland, 2008). The higher hydration level resulted in the same gelatinisation degree however the higher temperature influenced structural reorganisation and swelling. In wheat starch, amylopectin is considered to contribute to water absorption, swelling and pasting of starch granules, whereas amylose 
and lipids tends to retard these processes (Blazek \& Copeland, 2008). However, the inverse relationship was found in waxy and non-waxy wheat starch was reported (Sasaki, Yasui \& Matsuki, 2000). Sasaki et al. (2000), reported that lower amylose content is associated with higher peak viscosity. Reduced amylose content starch relates to greater swelling. Greater swelling reduces the quantity of free water and is associated with higher pasting viscosity (Sasaki, et al., 2000). The controversy of these two studies could be due to a different variety of wheat starch. In the present study, the samples underwent hydrothermal treatment prior to RVA analysis which differed from native granules considered in the literature. This could be another point to consider on variation of the obtained results compared to literature data. Blazek and Copeland (2008) suggested that the trends in viscosity changes as a function of amylose content varied. Starches with $30 \%$ amylose generally display decreasing RVA peaks viscosity and breakdown values with increasing amylose content, whereas final viscosity tends to increase with increasing amylose content (Blazek \& Copeland, 2008).

Based on the results of RVA, effect of hydrothermal treatments can be explained in 3 different situations: (1) high hydration/moderate heating temperature, (2) high hydration/high heating temperature and (3) low hydration/moderate and high heating temperature.

(1): A65 samples (high hydration/moderate heating temperature), starch granules could swell under mild extent (Malumba, et al., 2013) but with a limited amylose leaching. Therefore, the viscosity was found to be lower than A85 samples while the granules size of A65 was found to be greatest among all samples. In wheat starch, annealing was found to decrease granular swelling, reduce amylose leaching, increase peak viscosity, increase thermal stability and decrease the extent of set-back (Jayakody \& Hoover, 2008 ). Heating starch at $65{ }^{\circ} \mathrm{C}$ in excess water is considered to be in the range of gelatinisation. However, the obtained results of $A 65$ samples demonstrated some similarities according to both annealing and gelatinisation effects. A65 samples were greatly swelling but decreased in peak viscosity. This variation might be due to hydrothermal treatment applied on the sample.

(2): A85 (high hydration/high heating temperature), the granules could undergo swelling at extensive extent directly without early mild swelling since the samples were immediately heated at $85^{\circ} \mathrm{C}$ (isothermal). The immediate heating at high temperature could 
promote gelatinisation and amylose leaching simultaneously. This is in agreement with literature data that higher heating rate resulted in a higher apparent viscosity as well as higher peak viscosity at faster heating rate during pasting (Patel \& Seetharaman, 2006). Increasing amylose content of starch has been proposed to decrease the melting temperature of granules by disrupting crystallinity in the granular structure, which could affected on the peak viscosity measurement with RVA (Blazek \& Copeland, 2008). This could possibly limit granule swelling. Morphological characteristics of wheat starch granules were found to change during heating by increasing in size upon increasing in temperature and above $70^{\circ} \mathrm{C}$, the granules tended to fold extensively (Patel \& Seetharaman, 2006).

The conditions of A85 could be considered as gelatinisation in excess water. This involved a two-stage process: slow helix-helix dissociation and fast helix-coil transition (Waigh, et al., 2000). The water first enters the amorphous growth rings and at a certain degree of swelling, disruptive stress is transmitted through connecting molecules from amorphous to the crystalline regions. Amylose molecules begin to leach from the granules as they are disrupted under shear and the viscosity of the resulting paste increases to a maximum, which corresponds to the points when the number of swollen but still intact starch granules is at maximum (Copeland, et al., 2009). The maximum is followed by a decrease in pasting viscosity, as the granules rupture and starch molecules are dispersed in the aqueous phase (Copeland, et al., 2009).

(3): C65 and C85 (low hydration/moderate and high heating temperature), the samples showed similarities in residual flavour and granule size but their pasting properties were significantly different. DSC suggested that C65 samples contain 36-40\% of residual native while C85 samples contained $13-25 \%$ residual native starch. The results of XRD and WAXS suggested that they were significantly different in \% crystallinity while SAXS showed a different degree of semi-crystalline disruption. The DSC, XRD, WAXS and SAXS results support the idea that the treatment of C65 and C85 promoted different extent of crystal melting. The similarity in granule size between $\mathrm{C} 65$ and $\mathrm{C} 85$ could be due to hydration effect. There was limited water for C65 and C85, therefore the swelling was limited. The absorbed water facilitates arrangement of helices side-by-side while the temperature promoted unwinding of helices and crystal melting (Waigh, et al., 2000). Thanks to higher temperature in $\mathrm{C} 85$, the samples had greater crystal melting and less residual native starch. 
In order to generalise the hydration effect on starch structure and rheology, the results of peak viscosity, granule size, \% residual native, \% crystallinity and \% flavour residual were subjected to PCA (Figure 5-1). Native and pregelatinised starches and sample without flavour addition were excluded from PCA analysis because they contained nonnumerical data. It is obvious that $A 65$ and A85 samples were similar, the main factors influenced on PCA distribution were granule size and peak viscosity (Figure 5-1). C65 and C85 samples were influenced by \% native residual, \% crystallinity and \% flavour residual. $\mathrm{C} 65 \mathrm{EH}$ was found to be a lot different from other samples according to its high residual native. Figure 5-1 represents general image of sample homogeneity. It could help explain the results in particular A65 and A85 which were very similar in structure but different in pasting properties. A65 samples were slightly greater in \% crystallinity and their SAXS profiles showed slightly bigger peaks comparing to A85 samples. DSC results suggested that A85 samples were fully gelatinised while A65 samples contained small residual native starch. These small differences between A65 and A85 samples were not statistically significant, especially when comparing each parameter. Gathering all the results could possibly explain the differences.

Flavour addition showed no significant influence or undetectable change at structure level but it showed significantly effect on pasting properties. The rate and extent of swelling and breakdown are dependent on the type and amount of starch, the temperature gradient, shear force and the composition of the mixture (Copeland, et al., 2009). Lipids, proteins, inclusion complex and small ligand molecule were reported to influence pasting properties (Blazek and Copeland, 2009; Copeland, et al., 2009; Tang and Copeland, 2007; Saibene \& Seetharaman, 2008; Q. Sun, et al., 2014). Hence, it is possible that the small residue of flavour could possibly affect molecular level (amylose/amylopectin chain) and drove variation in pasting properties among the samples.

\subsection{Starch-flavour interaction versus physical state}

\subsubsection{Flavour retention and release}

The result of extraction of freeze-dried samples showed no significant loss due to freeze-drying. This emphasised that the interaction between starch and flavours were strong enough to retain the flavours. Upon storage under humidified conditions, the higher humidity promoted greater flavour release. This is in accordance with the study in flavour 
encapsulation that ethyl hexanoate had a greater release at $75 \% \mathrm{RH}$ than $52 \% \mathrm{RH}$ due to increasing of flavour diffusion (Gharsallaoui, Roudaut, Beney, Chambin, Voilley \& Saurel, 2012). SPME results showed that ethyl hexanoate was greater released than 2 -hexanone at both $58 \%$ and $75 \% \mathrm{RH}$. Ethyl hexanoate is reported to be able to form inclusion complex with starch (Jouquand, et al., 2006), therefore it is expected that ethyl hexanoate could be retained in the sample better than 2-hexanone although the complex formation could not be detected. The obtained results showed that 2-hexanone which is reported as noninclusion complex ligand or low complex formation (Jouquand, et al., 2006; Waigh, et al., 2000) was surprisingly more stable upon storage at $58 \%$ and $75 \% \mathrm{RH}$ than ethyl hexanoate. This suggested that complex formation is not the only factor affecting flavour retention and release. The solubility and polarity of flavour as well as physical state are involved in stability of flavours upon storage. It this study, solubility of flavour seems to play an important role in retention and release. 2-Hexanone has higher solubility in water than ethyl hexanoate therefore it was better retained and less released.

Samples A65 and A85 are similar in \% crystallinity. They showed similar pattern of flavour release. Comparing the overall results of C65 and C85, it seems like C65 was greater release than $\mathrm{C} 85$ at both \%RHs. Consider the result between $\mathrm{A}$ and $\mathrm{C}$ samples, no clear pattern can be drawn and this brings about an unclear remark whether \% crystallinity influence release pattern or not. Moreover, the samples evolved upon storage, this could also affect flavour release profiles.

This study demonstrated that saturated $\mathrm{NaCl}$ is able to interact by trapping the flavour within saturated salt phase. The result was obvious for ethyl hexanoate while the contents were too low to be detected in the case of 2-hexanone.

\subsubsection{Structural relaxation}

It was expected that flavour could affect on structural relaxation. The results of this study found that there was no significantly difference in enthalpy relaxation at 14 weeks. However, the trend of relaxation between each set was different. The study time (14 weeks) seemed to be too short to explain relaxation behaviour of each sample group. Upon 14 weeks of storage, only 2-hexanone containing samples that showed the constant trend of enthalpy relaxation at 4 weeks while samples other samples showed continuously increasing trends. 
Regarding the trend lines of enthalpy relaxation, the sample with ethyl hexanoate showed increasing enthalpy relaxation during 14 weeks while sample with 2-hexanone and without flavour showed constant trends at 4 weeks of storage. This was possible to relate to the release pattern of ethyl hexanoate. The results of SPME and structural relaxation suggested that samples evolved upon storage and tend to release ethyl hexanoate upon relaxation.

Chung, Chang and Lim (2004), postulated that the extent of relaxation in partially melted starches increased proportionally with the level of amorphous fraction, whereas the rate of relaxation decreased as the amorphous fraction increased. This statement cannot apply to the results the present study because sample $A$ and $C$ showed similar extent and rate of relaxation. The samples of the present study contained ternary phase (flavours) which interacted and affected by humidity. Moreover they also differed by their granular and sub-granular structure, which could be another possible explanation for the contrasted result. 


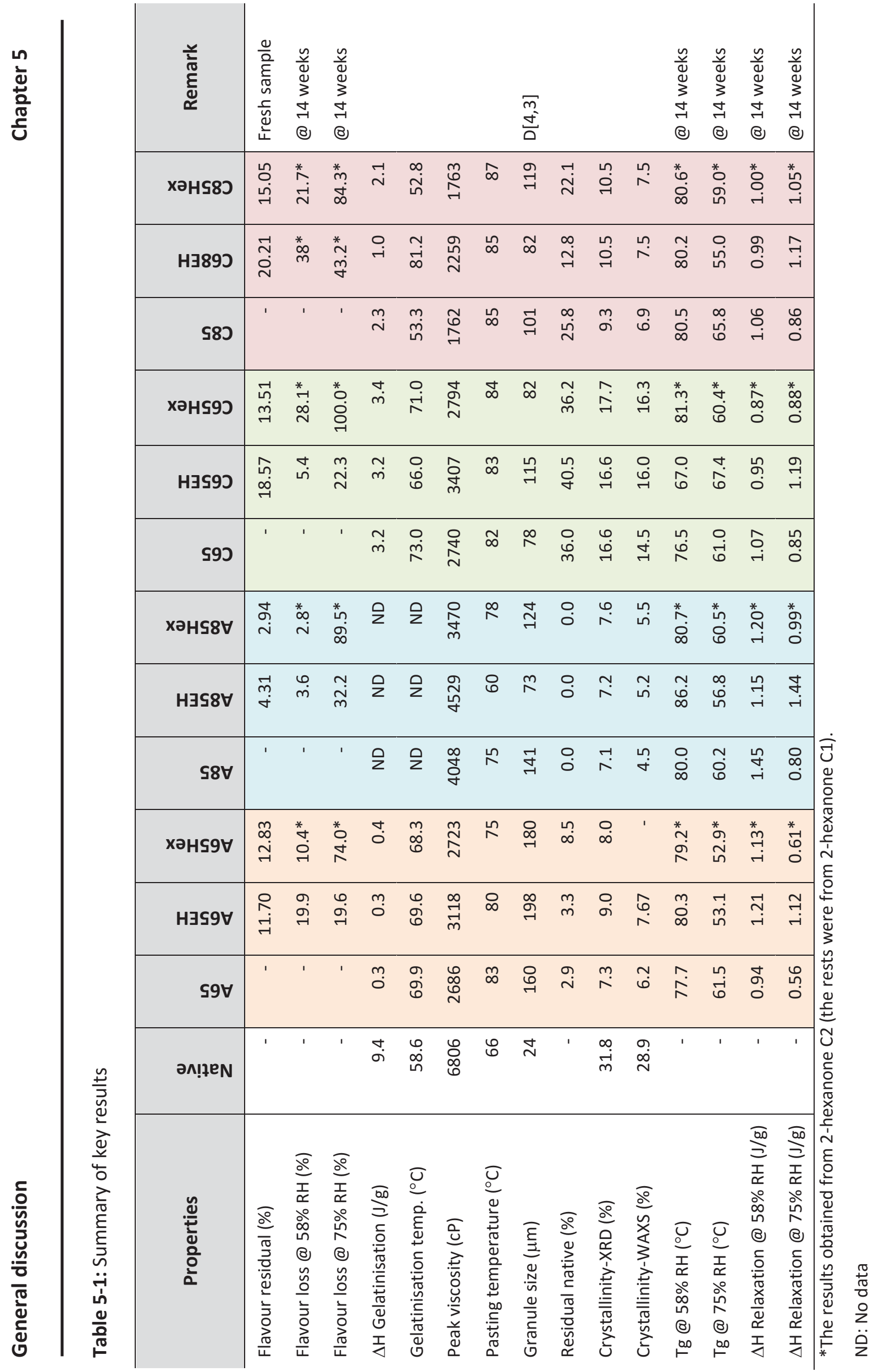




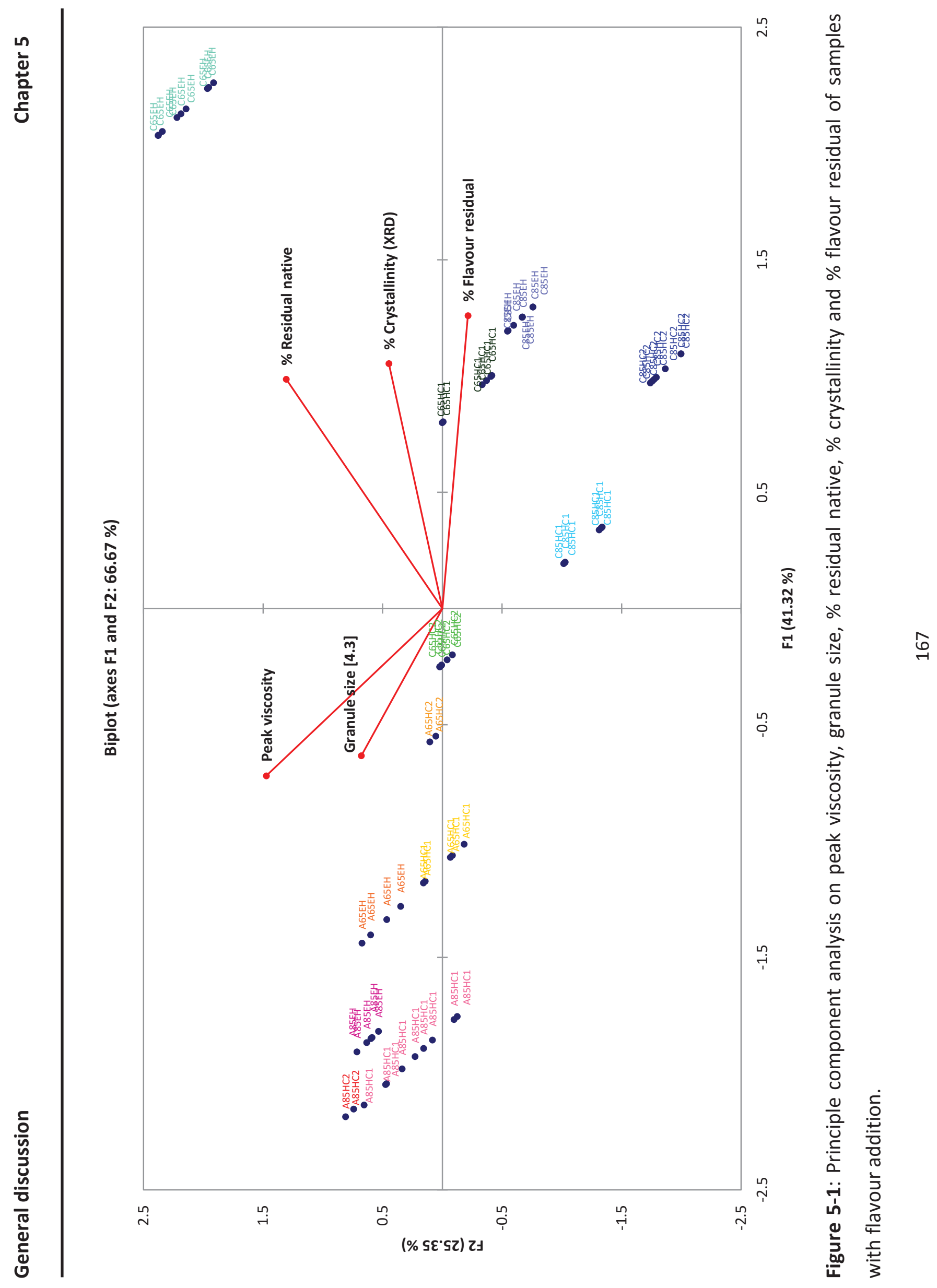


Chapter 6: Conclusion and perspectives 


\section{Findings:}

The results of this study suggested that heat treating starch with $80 \%$ moisture at 65 and $85{ }^{\circ} \mathrm{C}$ led to annealing and gelatinisation, respectively. It is suggested that the best annealing temperature is in vicinity of gelatinisation temperature. Although, $65^{\circ} \mathrm{C}$ is above gelatinisation temperature of wheat starch but the overall results suggested hydrothermal treatment on A65 samples resulted in some similarities to annealing effects rather than gelatinisation. Both $\mathrm{C} 65$ and C85 results showed effect of heat-moisture treatment. Ethyl hexanoate and 2-hexanone were proved to be able to interact with starch under limiting water conditions. The overall extraction results of wet samples demonstrated no significant difference in loss of ethyl hexanoate and 2-hexanone. The main loss of flavour was due to vaporisation at high hydration and temperature. Although flavour-inclusion complex could not be detected by DSC, XRD and WAXS but residual flavour were detected upon freezedrying and storage study. The type of interaction between flavour and starch is speculated to be binding and hydrophobic interactions however the localisation of flavour remains unclear. FTIR could be used as a rapid technique for flavour-inclusion complex or starchflavour interaction study. However, it requires pre-treatment to enhance the sensitivity of the technique.

The hydrothermal treatment resulted in different pasting profiles and granule size. Sample A65 had the greatest granule size but lowest peak viscosity compared to A85. Sample C65 and C85 were similar in granule size but C65 showed greater peak viscosity. This suggested that heating temperatures had effects on structural changes and reorganisation through different degree of crystal melting and amylose leaching.

The results of residual native starch were different from \% crystallinity however it showed the same trends since: A85 contained no residual native starch and had less \% crystallinity, C65 contained highest residual native starch and \% crystallinity. The results of residual native and \% crystallinity emphasised the measurement of different properties of crystal.

SPME analysis demonstrated that flavour release increased upon increasing humidity. Ethyl hexanoate had a greater release than 2-hexanone at $75 \% \mathrm{RH}$ and had similar release profiles at $58 \% \mathrm{RH}$. Flavour addition influenced trend of relaxation. The relation between structural relaxation flavour and release pattern over time is not that clear. It is difficult to pinpoint a specifically relaxing sample with a clearly different release which can be 
associated to the structural relaxation. For storage properties at least, the whole set of samples although different by their structure do not exhibit a clear different behavior either for the flavour release or for the structural relaxation. When both properties are considered for a possible relations, nothing clearly appears.

\section{Perspectives and improvements:}

The study of starch-flavour interaction under limiting water requires conditions adjustment such as: increasing and varying the flavour amount (to be increased) and type, varying hydration level and heating temperature. Most importantly trying more extreme hydration and temperature conditions may lead to samples with clearer differences and possibly different properties on the investigated behaviours. This could help identify the existing interaction (complex/non-complex) as well as localise the flavour. The parallel study with other type of starch or carbohydrate would help understanding the hydration effects (annealing, gelatinisation and heat-moisture treatments) which are varying among carbohydrate types.

Regarding structural study, curve-fitting technique on WAXS scattering profile seem to be a promising technique. It is interesting to apply curve-fitting technique by fitting on each scattering peak to understand structural transformation, loss or increase in crystallinity, and identify flavour-inclusion complex. Dynamic SAXS (or dynamic SAXS coupling with RVA) is another possible technique to understand structural transformation upon hydrothermal treatment. Little had been done with these techniques on semi crystalline starch and this preliminary work appeared to the team running the facilities as a new field of interest. This technique could clarify the change of crystallinity and viscosity development of each sample.

More variation of storage humidity is required in order to see the stability and find the best temperature and humidity to store the resulting products. Study scale of flavour release and retention can be adjusted to facilitate result comparison: SPME could be scaled up or using purge and trap technique, or scaleed down extraction to be micro-LikensNickerson which could also reduce the size of experimental error. More study is required to understand interaction between flavour and saturated salt. 


\section{Application of this study:}

Little was known about starch-flavour interaction under limiting water conditions, this study, its findings and outputs filled or lessened the gap of lacking information. We may have understood why so little has been investigated on partially gelatinised starch, indeed controlling the degree of partial melting is difficult and may sometimes lead to heterogeneous samples. The sample preparation technique of this study could be further developed for certain applications in food: flavour encapsulation, modification of food texture and volume (as benefit from granule swelling and viscosity change), making resistant starch upon starch-flavour interaction and starch structural transformation. The resulting samples which can be considered as pre-gelatinised starch could be used or subsidised in ready to eat and pre-cooked food since they require shorter gelatinisation time. Moreover, they contain and preserve the flavour within their structure. The results of SPME study under humidified conditions gave an idea for a development of flavour stability of humidified/wet food with short shelf life or require fast release. 
Chapter 7: Résumé substantiel 


\section{Contribution de l'eau et de la température à la structuration de matrices d'amidon en présence d'arômes}

\section{Introduction}

\section{A: L'amidon et son importance}

L'amidon est une macromolécule précieuse et la deuxième plus abondant biomatériaux naturels, avec la cellulose (Sablani, et al., 2007). Il est une source d'énergie bon marché par rapport à d'autres macromolécules. En ce qui concerne l'apport d'énergie en alimentation humaine, les polysaccharides y contribuent pour 40 à $50 \%$, avec $4 \mathrm{kCal} / \mathrm{g}$ (Biliaderis, 1991; FAO, 1998). Parmi toutes les sources d'apport énergétique, l'amidon est le plus important (FAO, 1998). L'amidon a été consommé comme un aliment de base depuis l'Antiquité (Schwartz \& Whistler, 2009). La fonction et l'utilisation de l'amidon ne sont pas seulement pour répondre à l'exigence de nutrition, mais aussi pour améliorer le goût et modifier la texture des aliments. Les différences de rugosité, de douceur et de viscosité dans l'aliment sont le résultat de différentes quantités d'amidon présentes. L'utilisation de l'amidon est diversifié par toute une gamme de modification structurelle pour obtenir des propriétés différentes: épaississement, gélification, encapsulation d’arôme, film et emballage, applications thermoplastiques, etc (Kaur, et al., 2012).

La recherche sur l'amidon se concentre sur le développement de processus et de techniques de production afin d'obtenir les fonctions, les propriétés désirées avec les plus hauts rendements. Par exemple, les sources d'amidon (mais, blé, riz...) sont classées en fonction de leurs teneurs en amylose en fonction des usages spécifiques en pâtisserie, boulangerie, pâtes alimentaires... L'hydrolyse dirigée est souvent appliquée à l'amidon pour conduire à plusieurs types de sirop de sucre, selon le nombre équivalent de dextrose (DE). Les études de la structure de l'amylose et des technologies de modification ont permis de produire des particules spécialisées comme les cyclodextrines. L'encapsulation des composés d'arôme (Ades, et al., 2012) et ou de substances actives pharmaceutiques (Rahmouni, et al., 2001; Zimonja \& Svihus, 2009) sont les exemples remarquables issues de la modification structurelle de l'amidon. Les études structurales sont toujours d'importance, car elles sont la clé pour comprendre les propriétés physiques et chimiques et d'élucider les interactions entre petites molécules et l'amidon dans des matrices diverses. 


\section{B: Origines et applications de l'amidon pour l'industrie}

Les principaux types d'amidon utilisés pour l'alimentation humaine et les applications industrielles sont le maïs, le manioc, le blé et la pomme de terre. Toutefois, le riz, le sagou, le sarrasin, le sucré, l'orge, l'arrow-root, sont également des sources importantes d'amidon (Ratnayake, et al., 2008). Plus de 60 millions de tonnes d'amidon sont produits annuellement dans le monde (Copeland, et al., 2009; Institut international Starch, 2012; Zucker Forschung Tulln, 2012).

L'amidon est principalement utilisé dans les produits alimentaires à $60 \%$ et pour des usages non alimentaires à environ 40\% (Copeland, et al., 2009). Pour les fins non alimentaires, elles sont constituées de l'agriculture (l'alimentation animale et l'enrobage des semences), la production pharmaceutique (comprimé et poudre de talc), plastique biodégradable, textile (chaîne, tissus et fils), du papier (carton ondulé, papier carton ), et les matériaux de construction et autres (fibres minérales, plaques de plâtre, béton, forage de pétrole, traitement de l'eau et de la colle) (Burrell, 2003; Calvert, 1997; Rahmouni, et al, 2001;. Sajilata \& Singhal, 2005; Singh, et al., 2007).

La structure unique et la chimie des granules d'amidon lui permettent de remplir plusieurs fonctions. L'amidon natif est idéal comme agent de texture dans la plus part des applications. L'amidon modifié est généralement utilisé surmonter les limitations de l'amidon natif, par une moindre résistance thermique ou une texture trop cohésive (Mason, 2009; Singh, et al., 2007). Les amidons, notamment hautement réticulé, sont stables à un pH faible, température élevée et sous la force de cisaillement, par conséquent, ils sont appliqués dans la sauce et les vinaigrettes (Mason, 2009). Utilisation de l'amidon en tant que matrice d'encapsulation réduit les pertes de composés volatils et limite l'oxydation des substances fragiles au cours du stockage (Ades et al., 2012). Pour aliments à faible humidité par exemple céréales de petit déjeuner, la teneur en amylose est un facteur crucial pour le croustillant, la texture courte, l'expansion: plus la teneur en amylose est élevée, plus le croquant et la stabilité sont grands. La transition vitreuse et la modification de structure de l'amidon se produisent au cours des processus de déshydratation, résultant de la fragilité du produit (Roudaut, et al., 2002). Cette propriété est recherché dans les produits car elle contribue non seulement à leur brillance et donc leur attractivité mais aussi à la prévention du produit contre l'humidité. 


\section{C: L'amidon à base de produits alimentaires et état vitreux}

L'amidon possède des propriétés physico-chimiques et nutritionnelles uniques (BeMiller \& Whistler, 1996). L'amidon pour être digestible doit subir des traitements hydrothermiques à travers la cuisson, l'extrusion, etc. Ces traitements hydrothermiques entrainent une perte de la cristallinité native (BeMiller \& Whistler, 1996; Kasapis, 2012; Le Meste, et al., 2002). Les amidons résultant des traitements hydrothermiques sont généralement peu stables en raison de leur taux d'humidité qui peut provoquer à la fois une altération microbienne et/ou une recristallisation, par exemple le rassissement des pains ou gâteaux, des nouilles fraîches...).

La déshydratation est associée à de nombreux processus, appliqués à des produits amylacés soit par le four, la cuisson-extrusion, la lyophilisation, le séchage par atomisation..., avec le même objectif: réduire la teneur en eau de la matrice alimentaire et modifier la texture des aliments cuits. En dehors des modifications de texture, il existe deux avantages à la déshydratation. L'un est la stabilisation des produits contre le risque microbiologique et un autre est le ralentissement de l'évolution des propriétés physiques de la matière à travers une diminution de la mobilité moléculaire. À la suite de la déshydratation de la matière peut passer d'un état caoutchouteux, à un état vitreux. La diminution de la mobilité moléculaire est associée à la transition vitreuse. Cette immobilisation a été invoquée pour comprendre la préservation des aliments dans le temps et éviter la détérioration des nutriments, des propriétés organoleptiques, le goût et le arôme (Bhandari \& Howes, 1999; Jiranuntakul, et al., 2011; Le Meste, et al., 2002). Typiquement, la qualité et l'intensité de l'arôme des produits alimentaires peuvent diminuer au cours du stockage. Immobiliser les composés d'arôme au sein de l'amidon vitreux et abaisser l'activité de l'eau permettent de préserver l'arôme des produits (Ubbink \& Krüger, 2006).

\section{D: Application des interactions petits ligands et amidon}

\section{Aspect de l'encapsulation d'arôme}

L'arôme des aliments est un paramètre est essentielle pour la perception du produit par le consommateur. Les approches en R\&D sont soit d'aromatiser le produit, soit de préserver l'arôme original, qui peut être modifié au cours de traitements ou de stockage du produit (Busso Casati, et al., 2007). De plus, les molécules d'arôme subissent facilement 
l'oxydation, ce qui entraîne une réduction de l'intensité d'odeur d'arôme et /ou le développement flaveur non souhaitée (Murua-Pagola, et al., 2009). L'encapsulation permet de restaurer ou de protéger le composé d'arôme en le fixant dans une matrice offrant une barrière protectrice vis à vis l'environnement indésirable. L'encapsulation facilite également le contrôle de la libération de l'arôme ainsi que la livraison d'autres ingrédients actifs à cible spécifique (Busso Casati, et al, 2007; Murua-Pagola, et al., 2009; Zasypkin \& Porzio, 2004). La complexité des matrices alimentaires nécessite une compréhension approfondie des phénomènes physiques et chimiques qui déterminent la stabilité, la libération, la perception et la digestion afin d'assurer une utilisation efficace de l'encapsulation (Ubbink \& Krüger, 2006).

L'amidon est en mesure de former un complexe d'inclusion amidon-arôme avec certains arômes comme l'hexanoate d'éthyle, linalol (Arvisenet, et al., 2002). Ces composés d'arôme se lient à l'amidon par des interactions non-covalentes dans la cavité hélicoïdale de l'amylose (Buléon, et al., 1998; Condé-Petit, et al., 2006). Les interactions amidon-arôme, particulièrement le complexe d'inclusion fascine les chercheurs dans le domaine l'encapsulation. C'est la structure de l'hélice d'amylose qui permet de donner des cyclodextrines, qui sont adaptés pour encapsuler les composés aromatiques hydrophobes (Conde-Petit, et al., 2006; Hau, et al., 1998). Il a été constaté que les matrices à base d'amidon donnent une meilleure rétention de l'arôme que d'autres agents de texture. Le complexe d'inclusion amylose-arôme se forme durant l'étape de gélatinisation et fourni une protection pendant le stockage par exemple (Hau, et al., 1998; Heinemann, et al., 2001; Nuessli, et al., 1997).

II y a de nombreux développements dans les technologies d'encapsulation par des ingrédients alimentaires actifs, y compris les polysaccharides vitreux et complexes de biopolymères (Ubbink \& Krüger, 2006). Les systèmes d'encapsulation vitreux à base de polysaccharides réduisent efficacement le taux de libération de l'arôme pendant le stockage, et minimiser le taux d'oxydation en limitant la diffusion de l'oxygène à travers la matrice d'hydrate de carbone vitreux (Ubbink \& Krüger, 2006).

Le concept de transition vitreuse est d'une importance capitale pour les polysaccharides amorphes. Les états vitreux et caoutchouteux d'un matériau se distinguent par leur position en ce qui concerne la température de transition vitreuse ( $\mathrm{Tg}$ ) (Angell, 1996). En état caoutchouteux, la structure de l'amidon est encore capable d'évoluer alors 
que la mobilité moléculaire est limitée en vertu de l'état vitreux (Ubbink \& Krüger, 2006). La température de transition vitreuse désigne la température critique où les changements de mobilité moléculaire deviennent très limités. La Tg diminue avec l'augmentation de la teneur en eau ou de l'activité de l'eau (Roos, 2007). Cela peut entrainer une évolution structurelle de l'amidon et modifier la mobilité des composés d’arôme.

\section{Aspect de nutrition}

Comme mentionné ci-dessus les aliments à base d'amidon sont importants pour l'alimentation humaine et servent comme source d'énergie principale. La digestion de l'amidon peut être classé en 3 catégories: l'amidon rapidement digestible (Edwards, Osborne, et Henry), amidon lentement digestible (SDS) et l'amidon résistant (RS) en fonction de leurs taux de libération de glucose et l'absorption dans le tractus gastro-intestinal (Englyst \& Hudson, 1996; Hung, et al., 2016). Les SDS et RS sont intéressants en raison de leurs avantages pour la santé. Le SDS assure un faible index glycémique (IG) qui améliore le contrôle glycémique chez les patients atteints de diabète sucré (Chung, et al., 2006). L'IG représente la réponse glycémique totale, 2 heures après la consommation de $50 \mathrm{~g}$ de polysaccharides et est exprimé en valeur relative de glucose (Chung et al., 2006). Le RS est la fraction non digestible dans l'intestin grêle, mais qui peut être digéré par fermentation bactérienne dans le côlon. Les produits issus de cette fermentation sont soupçonnés d'avoir plusieurs avantages pour la santé tels que la prévention du cancer colorectal, la réduction du risque de maladie cardiaque etc. (Goñi, et al., 1996; Hung, et al., 2016).

Il y a plusieurs travaux de recherche qui suggérent que l'amidon résistant ainsi que de l'amidon lentement digestible sont formés non seulement par la modification chimique ou enzymatique de l'amidon, mais aussi par des traitements hydrothermaux (Chung et al., 2006; Holm, et al., 1988; Hung, et al., 2016; Kawai, et al., 2012; Rodríguez \& Bernik, 2014). Les RS peuvent être formés lors de la combinaison de traitement à l'acide et de la chaleurhumidité sans changement de cristallinité (Hung, et al., 2016). En ce qui concerne les amidons résultants de traitement hydrothermiques, leurs digestibilités peuvent être modifiées en fonction du degré de cristallinité et le type d'interactions. Les paramètres les plus importants qui affectent la cinétique de l'hydrolyse de l'amidon sont la cristallinité et la surface d'échange (Rahmouni, et al., 2001). La cristallinité résiduelle dans les échantillons d'amidon sert de rigidité structurelle et possède une relation inverse avec la vitesse 
d'hydrolyse (Chung et al., 2006). Les matrices amorphes peuvent être digérées par les enzymes plus facilement et plus rapidement que les parties cristallines (Holm, et al., 1988; Rahmouni, et al., 2001). Toutefois, le taux de matrices amorphes peut être différent selon le degré de gélatinisation (Holm, et al., 1988). L'amidon partiellement gélatinisé se trouve être plus résistant à la digestion enzymatique que ceux rétrogradés (Chung et al., 2006). Considérant l'organisation structurelle, il a été constaté que l'amidon de type $B$ est plus résistant à la digestion enzymatique de l'amidon de type A (Tester, et al., 2006). La formation du complexe qui survient généralement entre l'amidon et ses lipides (ligands endogènes ou introduites) diminue fortement I'hydrolyse enzymatique de l'amidon (Kawai, et al, 2012;. \& Bernik Rodríguez, 2014).

\section{Contexte et Objectifs}

\section{Contexte}

De nombreuses études ont été conduites avec des amidons ayant subis un traitement hydrothermiques en présence de composés d'arôme. II a été montré que des complexes d'inclusion pouvaient se former avec les composés d'arôme. Les effets du vieillissement de la structure de l'amidon sur la rétention-libération des composés d'arôme ont également étudiés. En revanche, dans des conditions d'hydratation intermédiaire voire réduite, les données sur la structure des amidons partiellement gélatinisés et de leur interactions avec des petits ligands sont peu connues.

Notre étude vise donc à comprendre les interactions entre l'amidon et l'arôme lors du traitement hydrothermique à l'hydratation et la température intermédiaire. Basé sur l'effet de l'eau sur la température de gélatinisation, les paramètres quantité d'eau ( $A$ : $80 / 20$ eau/amidon et $\mathrm{C}: 50 / 50$ eau/amidon) et température de chauffage $\left(65^{\circ} \mathrm{C}\right.$ et $\left.85^{\circ} \mathrm{C}\right)$ sont variées afin d'obtenir des échantillons à différents degrés de gélification $(A 65, A 85$, C65, C85). Il est également intéressant de mieux comprendre l'évolution de la stabilité des amidons résultants avec différents taux de cristallinité et en présence d'arôme. Les amidons après traitements hydrothermiques ont été lyophilisés afin de préserver leurs structures. De cette façon, la structuration obtenue par le traitement thermique ne pouvait pas être affectée par la rétrogradation. Les amidons lyophilisés sont à l'état vitreux. Lors de l'étude 
de stabilité, les échantillons ont été stockés à différentes humidités relatives. Les différentes propriétés des arômes choisies conduisent à une étude sur les quantités de rétention et de libération à partir des amidons traités thermiquement. Deux composés d'arôme avec des possibilités différentes d'interagir avec l'amidon: hexanoate d'éthyle (complexant) et 2hexanone (non-complexant) sont choisis pour une étude comparative.

\section{Objectifs}

- Expliquer la contribution et le rôle de l'eau dans la structuration de matrices d'amidon pendant le processus thermique

- Caractériser les interactions de l'amidon et de composés d'arôme par rapport à l'état physique de l'amidon

- Comprendre les effets de la structuration et de la teneur en eau sur la rétention, libération des composés d'arôme à partir des matrices d'amidon.

Selon les objectifs de cette étude, la synthèse des résultats et la discussion sont divisée en deux aspects: 1-effet du traitement hydrothermiques sur la structure des matrices et 2-interactions amidon/arôme en rapport à un état physique. Le premier point à discuter porte sur les effets du traitement hydrothermique sur les changements structuraux, de la rhéologie résultante et les interactions avec les arômes. Le deuxième aspect concerne la rétention/libération de l'arôme en fonction de l'état d'hydratation et de relaxation structurelle. Afin de faciliter la discussion, quelques-uns des principaux résultats ont été résumés dans le tableau 7-1.

\section{Résultats et Discussion générale}

\subsection{Effet du traitement hydrothermique}

\subsubsection{Structure et Rhéologie (niveau de granulaire et sous-granulaire)}

Les différences observées dans le profil RVA (Rapid Viscosity Analyser) et la taille des granules de deux groupes d'échantillons ( $\mathrm{A}$ et $\mathrm{C}$ ) étaient dus à des taux de gonflement des granules d'amidon. Le pouvoir de gonflement a été corrélé avec des caractéristiques de viscosité de l'amidon de blé (Blazek et Copeland, 2008). Un niveau d'hydratation élevé (80\% eau/MS) a entraîné le même degré de gélatinisation cependant une température plus 
élevée a influencé la réorganisation structurelle et le gonflement des granules. Dans l'amidon de blé, l'amylopectine est considéré comme contribuant à l'absorption de l'eau, au gonflement et de la viscosité de la matrice, alors que l'amylose et les lipides ont tendance à retarder ces processus (Blazek et Copeland, 2008). Cependant, la relation inverse a été trouvée dans l'amidon de blé cireux et non cireux (Sasaki, et al., 2000). Sasaki et al. (2000) ont indiqué qu'une faible teneur en amylose était associée à une viscosité maximale plus élevée. La réduction de la teneur en amylose de l'amidon concerne plus le gonflement. Un grand gonflement réduit la quantité d'eau libre et est associé à une viscosité plus élevée (Sasaki et al., 2000). La controverse de ces deux études pourrait être due à une variété différente de l'amidon de blé. Dans la présente étude, les échantillons ont subi un traitement hydrothermique avant l'analyse RVA, les granules ne sont donc plus à l'état natif comme considérés dans la littérature. Cela est un autre point à considérer sur la variation de nos résultats par rapport aux données de la littérature. Blazek et Copeland (2008) ont suggéré que les tendances en matière de changements de viscosité étaient fonction de la teneur en amylose modifié. Pour des amidons avec 30\% d'amylose la viscosité mesurée par RVA finale tend à augmenter avec l'augmentation de la teneur en amylose (Blazek et Copeland, 2008).

Basé sur les résultats de la RVA, les effets des traitements hydrothermiques peuvent être expliqué dans 3 situations différentes: (1) haute hydratation / température de chauffage modéré, (2) à haute hydratation / haute température de chauffage et (3) la faible hydratation / modérées et haute température de chauffage.

(1): A65 échantillons (haute hydratation / température de chauffage modéré), les granules d'amidon pourraient gonfler sous avec ce traitement modéré, mais la libération de l'amylose du granule serait limitée (Malumba, et al, 2013). Par conséquent, la viscosité finale est alors inférieure à celle d'A85, même si la taille des granules d'A65 est le plus grande parmi tous les échantillons. L'amidon $A 65\left(65^{\circ} \mathrm{C}\right.$ et excès d'eau) est considéré comme étant dans la gamme de gélatinisation.

(2): A85 (haute hydratation / haute température de chauffage), les granules pourraient subir un gonflement plus intense et immédiat sans débuter par une phase de léger gonflement puisque les échantillons sont immédiatement chauffés à $85{ }^{\circ} \mathrm{C}$ (isotherme). Le chauffage à $85^{\circ} \mathrm{C}$ pourrait promouvoir la libération de l'amylose et la gélatinisation simultanément. Ceci est en accord avec les données de la littérature que le 
chauffage plus élevé entraîne une viscosité apparente plus élevée ainsi que la hausse pic de viscosité avec un chauffage rapide (Patel et Seetharaman, 2006). L'augmentation de la teneur en amylose de l'amidon serait impliquée dans la diminution de la température de fusion des granules en perturbant la cristallinité dans la structure granulaire, ce qui pourrait affecter la mesure de la viscosité de pic RVA (Copeland et Blazek, 2008). Cela pourrait limiter le gonflement des granules. Les caractéristiques morphologiques des grains d'amidon de blé sont modifiés au cours du chauffage en augmentant de taille lors de l'augmentation de la température, et au-dessus de $70{ }^{\circ} \mathrm{C}$, les granulés ont tendance à gonfler largement (Patel et Seetharaman, 2006).

Les conditions pour l'échantillon A85 peuvent être considérées comme une gélatinisation en excès d'eau. Cela implique un processus en deux étapes: la dissociation lente hélices-hélice de l'amylose et une transition rapide hélice-bobine (Waigh, et al., 2000). L'eau entre dans les premiers anneaux de croissance amorphe et à un certain degré de gonflement, le stress perturbateur est transmis à travers la connexion à partir de molécules amorphes pour les régions cristallines. Les molécules d'amylose commencent à lixivier depuis les granules et la viscosité de la matrice augmente jusqu'à un maximum, ce qui correspond à des points où le nombre de granules gonflés mais encore intactes est au maximum (Copeland, et al., 2009). Le maximum est suivi d'une diminution de la viscosité suite la rupture des granules d'où les molécules d'amidon sont dispersées dans la phase aqueuse (Copeland, et al., 2009).

(3): C65 et C85 (faible hydratation / température de chauffage modéré et élevé), les échantillons ont montré des similitudes pour les quantités d'arôme résiduelles et la taille des granules, mais leurs propriétés rhéologiques sont significativement différentes. La DSC montre que les échantillons C65 contiennent 36-40\% de l'amidon natif résiduelle tandis que les échantillons C85 contenaient 13-25\% d'amidon natif résiduelle. Les résultats de diffraction des rayons $X$ et WAXS suggèrent que les échantillons sont significativement différents, le \% de cristallinité montre un degré différent de perturbation de l'état semicristallin. Les résultats en DSC, XRD, WAXS et SAXS appuient l'idée que le traitement hydrothermique de $\mathrm{C} 65$ et C85 ont engendré des différences dans la fusion des cristaux. La similarité de la taille des granules entre C65 et C85 peut être due à l'effet d'hydratation. En effet la quantité d'eau est limitée pour C65 et C85, et donc le gonflement est limité. L'eau absorbée facilite la disposition des hélices côte à côte tandis que la température engendre 
le déroulement des hélices et la fusion des cristaux (Waigh, et al., 2000). Grace à une température plus élevée pour $\mathrm{C} 85$, les échantillons ont une plus grande proportion de cristaux fondus et moins d'amidon natif résiduel.

Afin de généraliser l'effet d'hydratation sur la structure de l'amidon et la rhéologie, les résultats de pic de viscosité (RVA), la taille des granules, le \% amidon natif résiduel, le \% de cristallinité résiduelle et le \% d'arôme ont été traités par analyse en composantes principales (APC) (Figure 7-1). Les amidons natifs et pré gélatinisés sans arôme ont été exclus de cette analyse ACP parce qu'ils contenaient des données non numériques. II est évident que A65 et A85 sont des échantillons similaires; les principaux facteurs qui influencent la distribution en ACP sont la granulométrie et le pic de viscosité (Figure 7-1). Pour C65 et C85 les échantillons ont été influencés par le \% amidon natif résiduel, le \% de cristallinité et le \% d'arôme résiduel. Le C65EH est très différent des autres échantillons pde par son \% amidon natif résiduel très élevé. La Figure 7-1 représente l'image générale de I'homogénéité des échantillons. Cela pourrait aider à expliquer les résultats, en particulier, A65 et A85 qui étaient très semblables dans leur structure mais différents dans les propriétés de rhéologique (RVA). Les échantillons A65 sont légèrement plus grands en \% de cristallinité et leurs profils légèrement plus grands en analyse SAXS comparer aux échantillons $A 85$. Les résultats suggèrent que A85 est totalement gélatinisé alors que A65 contenait de petites quantités amidon natif résiduel. Ces petites différences entre A65 et A85 ne sont pas statistiquement significatives, en particulier lorsque I'on compare chaque paramètre.

La présence d'arôme n'a montré aucune influence notable ou indétectable sur le changement structure des amidons, par contre elle semble affecter de manière significative sur les propriétés d'empesage. La vitesse et le degré de gonflement et la répartition sont fonction du type et de la quantité d'amidon, le gradient de température, la force de cisaillement et la composition du mélange (Copeland, et al., 2009). Les lipides, les protéines, les complexes d'inclusion avec de petite molécule de ligand ont été signalés comme influencant les propriétés d'empesage (Blazek et Copeland, 2009; Copeland, et al, 2009;. Tang et Copeland, 2007; Saibene \& Seetharaman, 2008; Q. Sun, et al. , 2014). Par conséquent, il est possible que les composés d'arôme même à faibles quantités peuvent affecter le niveau moléculaire (amylose / chaînes d'amylopectin) et conduire à des variations des propriétés d'empesage entre les échantillons. 


\subsubsection{Interaction d'arôme}

Selon les données de la littérature, il est suggéré fréquemment que l'hexanoate d'éthyle est capable de former un complexe d'inclusion avec de l'amidon pendant la phase de gélatinisation (Pozo-Bayon, et al., 2008). Certains auteurs ont suggéré que la 2-hexanone est incapable de former un complexe d'inclusion (Jouquand, et al., 2006) tandis que d'autres ont montré qu'il est possible de former un complexe mais avec un peu faible indice complexation (Waigh, et al., 2000). Bien que nos résultats ne puissent pas identifier clairement la formation d'un tel complexe, nous avons démontré et prouvé qu'au moins un de deux composés d'arôme pouvait interagir avec l'amidon dans des conditions de chaleur modérées et d'eau limitant.

Les interactions mis en place étaient assez fortes pour conserver de l'arôme au sein de l'amidon et dans les produits après lyophilisation et au cours de l'étude de stockage. En ce qui concerne le 2-hexanone, la présente étude a montré qu'il est capable d'interagir avec l'amidon d'une manière similaire comparé à l'hexanoate d'éthyle (Tableau 7-1). Ce résultat est opposé à celui de Jouquand et al. (2006), ce qui peut être dû à l'échantillon obtenu dans des conditions de préparation différentes.

La gélatinisation facilite le déroulement des hélices d'amylose et permet aux molécules de ligands pénétrer à l'intérieur, d'être piégés et de former des complexes d'inclusion (Pozo-Bayon, et al., 2008). Après gélatinisation et refroidissement, la recristallisation se produit (Pozo-Bayon, et al., 2008)). Par conséquent le complexe d'inclusion peut être détecté par diffraction des rayons $X$. Dans cette étude, les échantillons après le traitement hydrothermique ont été refroidis à température ambiante, puis congelés afin d'éviter la rétrogradation. Ces conditions de préparation de l'échantillon peuvent ne pas convenir ou limiter la co-cristallisation de l'arôme dans le complexe d'inclusion

Selon les données de la littérature, la formation de complexe joue un rôle important dans l'interaction amidon-arôme (Le Thanh, et al., 1992). Dans notre étude nous montons que les composés d'arôme interagissent avec l'amidon. Cependant une étude plus approfondie pourrait expliquer la localisation des liaisons entre les molécules d'amidon et l'arôme car malheureusement les complexes d'inclusion étaient indétectables. Pour notre étude, la localisation du composé d'arôme au sein des chaines d'amidon reste floue. Les résultats de WAXS montrent une intensité croissante du pic à certains domaines 
caractéristques de la formation de complexe (Jouquand et al., 2006; Le Bail, 2005; RondeauMouro, et al., 2004). Cependant ces pics ne suffisaient pas vraiment car un doute existe sur la structure qui pourrait correspondre aussi à un amidon qui n'a pas été complètement gélatinisé (et toujours semblable à cristal natif). Cependant, nos résultats de WAXS sont prometteurs. Une étude de comparaison en faisant varier la température de chauffage et la concentration de l'arôme pourrait aider à identifier la localisation de l'arôme. La FTIR est une autre technique intéressante à développer pour la détection du complexe d'inclusion ou de l'interaction amidon arôme.

Selon le composé d'arôme et la quantité résiduelle, le traitement hydrothermique a affecté l'interaction amidon-arôme de 2 façons différentes. A haute hydratation, la température joue un rôle important sur l'eau et la vaporisation de l'arôme ce qui a donc causé des pertes élevées en arôme. A faible hydratation, il n'y a eu aucun effet significatif de la température de chauffage sur la perte d'arôme à l'exception de la 2-hexanone à la concentration élevée (C2). L'énorme perte de arôme pour l'échantillon C65 avec 2hexanone à concentration $\mathrm{C} 2$ pourrait être due à la température de chauffage, qui était trop faible pour permettre le déroulement des chaines amylose / amylopectine et la fusion des cristaux ; ainsi l'arôme a finalement été empêché de pénétrer dans la structure de l'amidon et de s'immobilisé. A $65^{\circ} \mathrm{C}$, la 2-hexanone pourrait probablement mieux de rester dans la phase aqueuse que à $85^{\circ} \mathrm{C}$. Mais à cette température, l'amidon et d'eau ont pris plus de temps pour interagir, et parvenir à piéger l'hexanone, ceci permettant à la 2-hexanone de se vaporiser à un taux supérieur. A $85^{\circ} \mathrm{C}$, la température est suffisamment élevée pour permettre à le déroulement de l'amylose / amylopectine et ce processus a eu lieu plus vite et mieux que à $65^{\circ} \mathrm{C}$. Cette hypothèse est en accord avec les résultats de l'analyse structurelle (DSC, XRD, WAXS et SAXS) que les échantillons C65 contenaient une cristallinité résiduelle native supérieure. Les données de SAXS ont montré que les couches cristallines de l'échantillon 665 sont totalement perturbées.

\subsection{Interactions amidon/ arôme par rapport à l'état physique}

\subsubsection{Arôme rétention et la libération}

Le résultat de l'extraction des arômes sur les échantillons lyophilisés ne montre aucune perte significative liée à la lyophilisation. Ceci souligne que les interactions entre l'amidon et les arômes étaient assez fortes pour maintenir les arômes dans les matrices. 
Lors du stockage des matrices d'amidon dans des conditions d'humidité contrôlées, un taux d'humidité élevé favorise une plus grande libération de composé d'arôme. Ceci est en accord avec des études d'encapsulation d'arôme; ainsi l'hexanoate d'éthyle a une plus grande libération à une humidité relative de $75 \%$ qu'à une humidité de $52 \%$, ceci serait due à l'augmentation de la diffusion de l'arôme dans la matrice (Gharsallaoui, et al., 2012). Les résultats SPME ont montré que I'hexanoate d'éthyle a été libéré en plus grande quantité que la 2 -hexanone à la fois $58 \%$ et $75 \%$ d'humidité relative. L'hexanoate d'éthyle est signalé comme étant capable de former des complexes d'inclusion avec de l'amidon (Jouquand, et al., 2006), par conséquent, il est supposé que l'hexanoate d'éthyle pouvait être mieux retenu dans l'échantillon que 2-hexanone, bien que la formation de complexe n'ait pas pu être détecté . Les résultats obtenus ont montré que le 2-hexanone, qui est signalée comme ne formant pas de complexe d'inclusion ou alors faiblement (Jouquand, et al, 2006; Waigh, et al, 2000) a été étonnamment plus stable lors d'un stockage à $58 \%$ et $75 \%$ d'humidité relative par rapport à l'hexanoate d'éthyle. Cela suggère que la formation du complexe n'est pas le seul facteur qui influe sur la rétention de l'arôme et de la libération. La solubilité et la polarité de l'arôme ainsi que l'état physique sont impliquées dans la stabilité des arômes lors du stockage. Dans notre étude, la solubilité de l'arôme semble jouer un rôle important dans la rétention et la libération. La 2-hexanone a une plus grande solubilité dans l'eau que I'hexanoate d'éthyle donc il a été mieux retenu et moins libéré quand I'humidité relative a augmenté.

Les échantillons $\mathrm{A} 65$ et $\mathrm{A} 85$ sont similaires en \% de cristallinité. II présente un modèle similaire de libération de l'arôme. En comparant les résultats globaux de C65 et C85, il semble que C65 avait plus grande libération de C85 aux deux \% RH testées. Considérant les résultats entre les échantillons $A$ et $C$, aucune tendance claire ne peut être tirée, ainsi il est difficile de savoir si le \% de cristallinité résiduelle dans les amidons influence la libération des composés d'arôme ou pas. En outre, les échantillons ont évolué lors du stockage, ce qui pourrait également affecter les profils de libération des composés d’arôme.

Notre étude a démontré également que la solution saturée en $\mathrm{NaCl}$ utilisée pour obtenir l'humidité relative désirée était capable d'interagir par piégeage avec le composé d'arôme situé en phase vapeur au-dessus de la matrice d'amidon testé. Ce résultat était évident avec l'hexanoate d'éthyle, par contre la teneur était trop faible pour être détectée dans le cas de 2-hexanone. 


\subsubsection{Relaxation de la structure}

Il était supposé que le composé d'arôme pourrait affecter la relaxation structurelle des chaines d'amidon. Les résultats de cette étude ont constaté qu'il n'y avait pas de différence significative dans la relaxation d'enthalpie à 14 semaines. Cependant, la tendance entre chaque échantillon était différente. Le temps d'étude (14 semaines) semblait être trop court pour expliquer le comportement de relaxation de chaque groupe d'échantillons. Après 14 semaines de stockage, seuls les échantillons contenant de la 2-hexanone présentaient une relaxation d'enthalpie stabilisée (valeur identique à 4 semaines de stockage) tandis que les autres échantillons montraient des tendances de la relation d'enthalpie en constante augmentation.

D’après les résultats de la littérature, l'évolution de la structure de matrice d'amidon au cours du stockage tend vers la relaxation ce qui a tendance à libérer l'hexanoate d'éthyle lors de la relaxation.

Chung et al. (2004), ont postulé que la plage de mesure de relaxation d'amidons partiellement gélatinisés augmente proportionnellement avec le niveau de la fraction amorphe, alors que le taux de relaxation diminue à mesure que la fraction amorphe augmente. Cette déclaration ne peut pas s'appliquer à nos résultats, car les échantillons $\mathrm{A}$ et $C$ ont montré une plage et un taux de relaxation similaire. Nos échantillons se présentent dans un système ternaire : amidon, arôme qui interagissent et sont affectés par l'humidité relative. De plus, nos échantillons diffèrent aussi par leur structure granulaire et sousgranulaire, ce qui pourrait être une autre explication possible pour ce résultat contrasté par rapport à la littérature. 


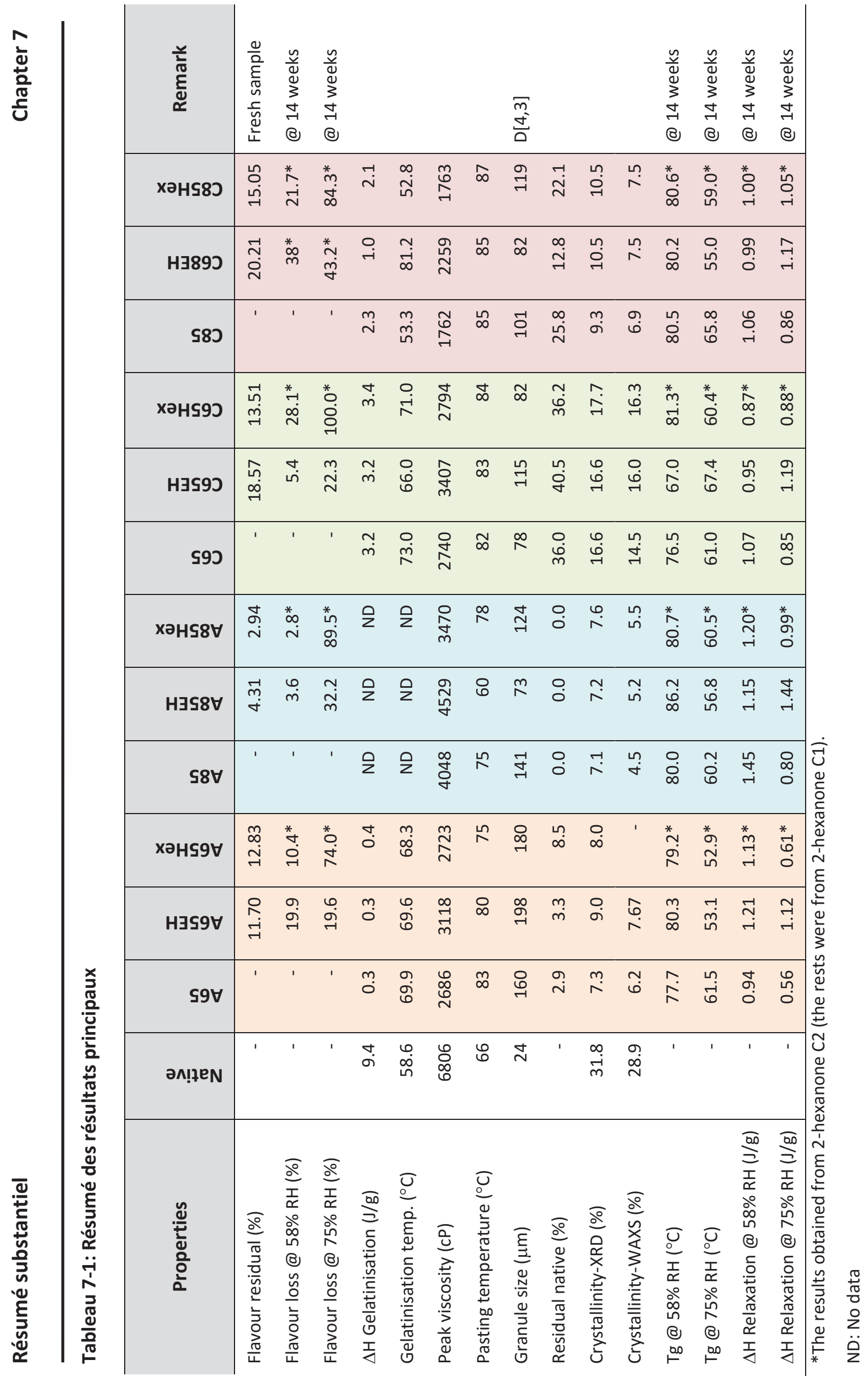




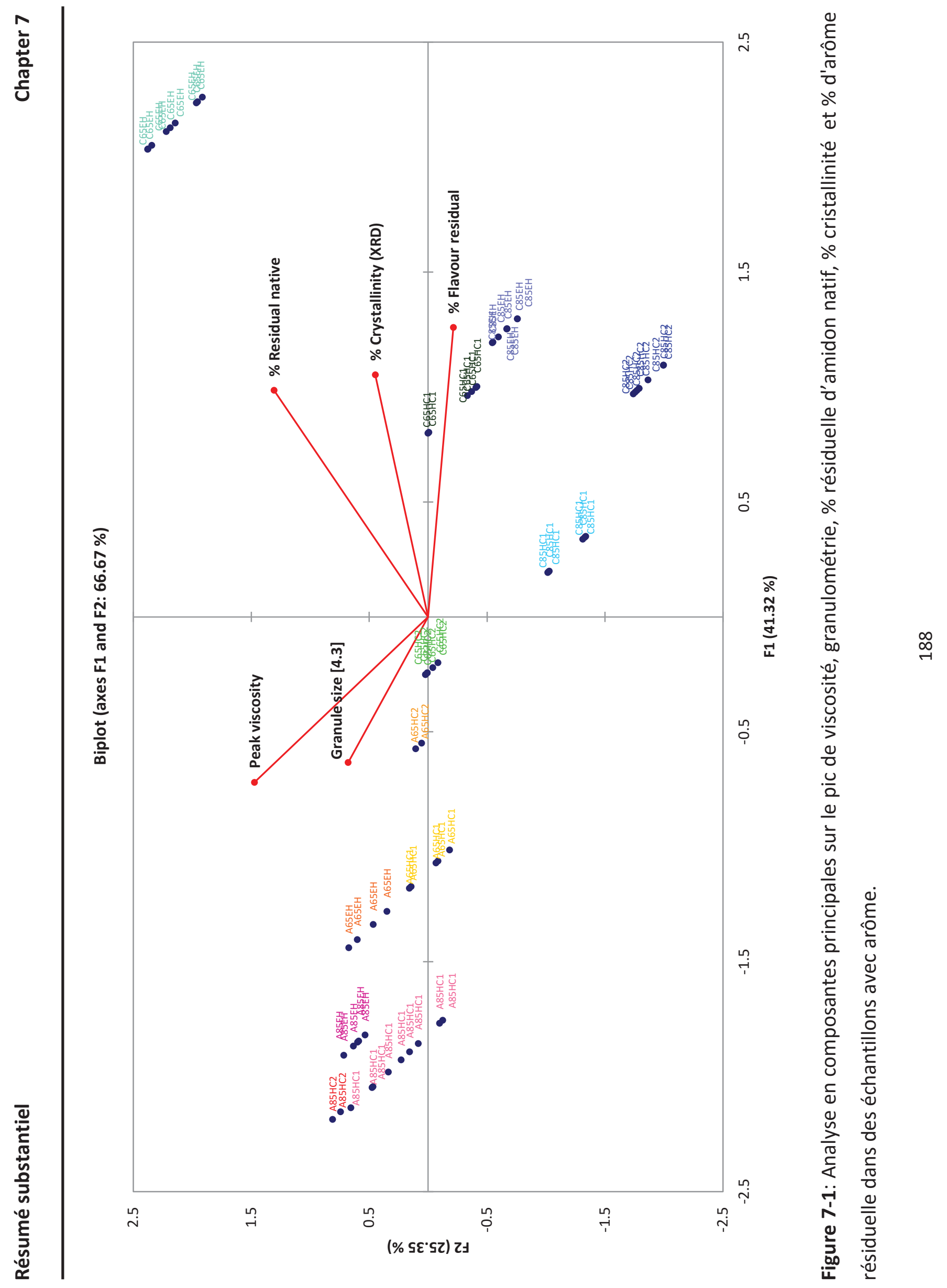




\section{Conclusion}

\section{Résultats:}

Les résultats de cette étude suggèrent que les conditions appliquées pour A65 (80\% d'humidité et le chauffage à $65^{\circ} \mathrm{C}$ ) et A85 (80\% d'humidité et le chauffage à $85^{\circ} \mathrm{C}$ ) conduisent à des échantillons partiellement ou totalement gélatinisés. Les résultats globaux suggérent que le traitement hydrothermiques sur l' échantillon A65 échantillons ont donné lieu à certaines similitudes recuit effets plutôt que gélatinisation. Les deux résultats $\mathrm{C} 65$ et C85 ont montré l'effet du traitement par la chaleur humide. L'hexanoate d'éthyle et de 2hexanone sont capables d'interagir avec l'amidon sous des conditions de limitation en eau. Les résultats globaux ne montrent aucune différence significative de la perte de l'hexanoate d'éthyle et de 2-hexanone. La principale perte d'arôme est due à l'évaporation par entrainement à la vapeur et la température. Bien que le complexe d'inclusion amidon arôme ne peut pas être détecté par DSC, XRD et WAXS, nous avons détecté des résidus d'arôme dans les matrices lyophilisées et au cours de l'étude de stockage. L'existence d'interaction entre l'arôme et de l'amidon est démontrée mais la localisation de l'arôme au sein des chaines d'amidon reste incertaine. FTIR pourrait être utilisé comme une technique rapide des complexes d'inclusion ou de l'étude d'interaction amidon arôme. Toutefois, elle nécessiterait des mises au point pour améliorer la sensibilité de la technique.

Le traitement hydrothermique conduit à des profils de viscosité et des tailles de granules différents. L'échantillon A65 avait la taille de granules la plus grande, mais une viscosité inférieure à celle de l'échantillon A85. Les échantillons C65 et C85 étaient similaires dans la taille des granules, mais C65 ont montré un pic de viscosité plus grand. Cela suggère que les températures de chauffage affectent la structure de l'amidon et la réorganisation et le degré de fusion de cristaux ainsi que la solubilisation de l'amylose.

Les résultats des taux d'amidon natif résiduel montrent des valeurs corrélées aux \% de cristallinité : A85 ne contenait aucune amidon natif résiduel et avait un faible \% de cristallinité, alors que C65 contenait plus un taux élevé natif amidon et un \% cristallinité plus important. Dans les échantillons A, les cristaux ont été fondu (mesure par DSC), mais il est resté éventuellement une petite fraction visible par les rayons $X$. Dans les échantillons $C$, les cristaux n'ont pas été entièrement fondus et leur présence était visible en DSC. Cependant, le traitement hydrothermique conduit un changement de la structure cristalline des 
échantillons C. Le changement dans la structure de conformation pourrait aboutir une faible diffusion des rayons $X$.

Les analyses SPME ont démontré que la libération d'arôme augmentait lors de l'augmentation de l'humidité relative de l'échantillon. L'hexanoate d'éthyle a une plus grande libération que la 2-hexanone à une humidité relative de $75 \%$ et avait des profils de libération similaires à $58 \%$ d'humidité relative. De plus la libération du composé d'arôme semble influencer par l'état de relaxation de la matrice au cours du stockage. Ainsi l'échantillon contenant l'hexanoate d'éthyle a montré une augmentation de l'enthalpie de relaxation pendant toute la durée de stockage, ceci s'accompagnant d'une libération du composé plus élevée.

\section{Perspectives et améliorations:}

L'étude de l'interaction amidon arôme en condition d'eau limitant nécessite un ajustement des conditions opératoires telles que: augmenter et varier la quantité et le type de composé d'arôme, varier le niveau de l'hydratation (raport eau/MS) et de la température de traitement thermique. Cela pourrait aider à identifier l'interaction produite (complexe / non complexe) ainsi que de localiser l'arôme au sein des macromolécules d'amidon. Une étude en parallèle avec un autre type d'amidon ou polysaccarides aiderait à comprendre les effets de l'hydratation (recuit, gélification et traitements chaleur et d'humidité) qui sont variables selon les types de polysaccharides.

En ce qui concerne l'étude structurale, l'ajustements de la courbe sur la technique de diffusion des profils WAXS semble être une technique prometteuse. II est intéressant d'appliquer la technique d'ajustement de courbe par emboîtement sur chaque pic de diffusion pour comprendre la transformation structurelle, la perte ou l'augmentation de la cristallinité, et d'identifier le complexe d'inclusion amidon-arôme. Le SAXS dynamique (ou le couplage SAXS dynamique avec RVA) est une autre technique possible pour comprendre la transformation structurelle lors du traitement hydrothermique. Cette technique permettrait d'expliquer le changement de viscosité, de cristallinité et le gonflement de chaque échantillon. 


\section{Application de cette étude:}

Les connaissances sur la nature des interactions amidon-arôme dans des conditions limitantes en eau, étaient parcellaires jusqu'ici, notre étude et ces conclusions sont une contribution pour remplir en partie ce manque d'informations.

La technique de préparation de l'échantillon de cette étude pourrait être développé pour certaines applications dans les aliments: l'encapsulation d'arôme, la modification de la texture des aliments et le volume (modulation du gonflement des granules, changement de viscosité), ce qui modifie l'amidon sur le plan structural et par rapport aux interactions. Les échantillons traités dans nos conditions peuvent être considérés comme de l'amidon prégélatinisé et pourrait être utilisé des produits dits pré-cuits car ils nécessitent ainsi un temps de gélatinisation réduit. 
References 


\section{References}

Ades, H., Kesselman, E., Ungar, Y., \& Shimoni, E. (2012). Complexation with starch for encapsulation and controlled release of menthone and menthol. LWT - Food Science and Technology, 45(2), 277-288.

Alvarado, P. M., Grosmaire, L., Dufour, D., Toro, A. G., Sánchez, T., Calle, F., et al. (2013). Combined effect of fermentation, sun-drying and genotype on breadmaking ability of sour cassava starch. Carbohydrate Polymers, 98(1), 1137-1146.

Angell, C. A. (1996). The glass transition. Current Opinion in Solid State and Materials Science, 1(4), 578-585.

Anonymous. (2012). Inform white paper: A basic guide to particle characterization. Malvern Instruments Limiteds.

Arancibia, C., Jublot, L., Costell, E., \& Bayarri, S. (2011). Flavor release and sensory characteristics of $\mathrm{o} / \mathrm{w}$ emulsions. Influence of composition, microstructure and rheological behavior. Food Research International, 44(6), 1632-1641.

Arvisenet, G., Le Bail, P., Voilley, A., \& Cayot, N. (2002). Influence of Physicochemical Interactions between Amylose and Aroma Compounds on the Retention of Aroma in Food-like Matrices. Journal of Agricultural and Food Chemistry, 50(24), 7088-7093.

Asaoka, M., Okuno, K., \& Fuwa, H. (1985). Effect of environmental temperature at the milky stage on amylose content and fine structure of amylopectin of waxy and nonwaxyendosperm starches of rice (Oriza sativa L.). Agric. Biol. Chem., , 49(2), 373379.

Baks, T., Ngene, I. S., van Soest, J. J. G., Janssen, A. E. M., \& Boom, R. M. (2007). Comparison of methods to determine the degree of gelatinisation for both high and low starch concentrations. Carbohydrate Polymers, 67(4), 481-490.

Beasley, M. M., Bartelink, E. J., Taylor, L., \& Miller, R. M. (2014). Comparison of transmission FTIR, ATR, and DRIFT spectra: implications for assessment of bone bioapatite diagenesis. Journal of Archaeological Science, 46(0), 16-22.

BeMiller, J. N., \& Whistler, R. L. (1996). Carbohydrate. In O. R. Fennema (Ed.), Food Chemistry. (3rd ed., pp. 157-223): Marcel Dekker.

Bhandari, B. R., \& Howes, T. (1999). Implication of glass transition for the drying and stability of dried foods. Journal of Food Engineering, 40(1-2), 71-79.

Biais, B., Le Bail, P., Robert, P., Pontoire, B., \& Buléon, A. (2006). Structural and stoichiometric studies of complexes between aroma compounds and amylose. 
Polymorphic transitions and quantification in amorphous and crystalline areas. Carbohydrate Polymers, 66(3), 306-315.

Biliaderis, C. G. (1991). The structure and interactions of starch with food constituents. Canadian Journal of Physiology and Pharmacology, 69(1), 60-78.

Biliaderis, C. G. (1992). Structures and phase transitions of starch in food systems. Food Technology, 46, 98-109.

Biliaderis, C. G. (2009). Structural transitions and related physical properties of starch. In J. BeMiller \& R. Whistler (Eds.), Starch: Chemistry and Technology (3rd ed., pp. 293372). New York: Academic Press.

Biliaderis, C. G., Page, C. M., Maurice, T. J., \& Juliano, B. O. (1986). Thermal characterization of rices starches: A polymeric approach to phase transitions of granular starch. Journal of Agricultural and Food Chemistry, 34, 6-14.

Blazek, J., \& Copeland, L. (2009). Effect of monopalmitin on pasting properties of wheat starches with varying amylose content. Carbohydrate Polymers, 78(1), 131-136.

Blazek, J., \& Copeland, L. (2008). Pasting and swelling properties of wheat flour and starch in relation to amylose content. Carbohydrate Polymers, 71(3), 380-387.

Blazek, J., \& Gilbert, E. P. (2011). Application of small-angle X-ray and neutron scattering techniques to the characterisation of starch structure: A review. Carbohydrate Polymers, 85(2), 281-293.

Borde, B., Bizot, H., Vigier, G., \& Buleon, A. (2002b). Calorimetric analysis of the structural relaxation in partially hydrated amorphous polysaccharides. I. Glass transition and fragility. Carbohydrate Polymers, 48(1), 83-96.

Borde, B., Bizot, H., Vigier, G., \& Buléon, A. (2002a). Calorimetric analysis of the structural relaxation in partially hydrated amorphous polysaccharides. II. Phenomenological study of physical ageing. Carbohydrate Polymers, 48(2), 111-123.

Boutboul, A., Giampaoli, P., Feigenbaum, A., \& Ducruet, V. (2002). Influence of the nature and treatment of starch on aroma retention. Carbohydrate Polymers, 47(1), 73-82.

Brittain, H. G. (2001). Particle-size distribution, Part I: Representations of particle shape, size, and distribution. Pharmaceutical Technology, 25(12), 38-45.

Buléon, A., Colonna, P., Planchot, V., \& Ball, S. (1998). Starch granules: structure and biosynthesis. International Journal of Biological Macromolecules, 23(2), 85-112. 


\section{References}

Buleon, A., Colonna, P., Leloup, V. (1990). Les amidons et leurs dérivés dans les industries des céréales. Industries Alimentaires et Agricoles, 107(6), 515-532.

Burrell, M. M. (2003). Starch: the need for improved quality or quantity-an overview. Journal of Experimental Botany, 54(382), 451-456.

Busso Casati, C., Schebor, C., Zamora, M. C., \& Chirife, J. (2007). Glass transition temperatures and some physical and sensory changes in stored spray-dried encapsulated flavors. LWT - Food Science and Technology, 40(10), 1792-1797.

Calvert, P. (1997). Biopolymers: The structure of starch. Nature, 389(6649), 338-339.

Cameron, R. E., \& Donald, A. M. (1992). A small-angle X-ray scattering study of the annealing and gelatinization of starch. Polymer, 33(12), 2628-2635.

Cameron, R. E., \& Donald, A. M. (1993a). A small-angle x-ray scattering study of starch gelatinization in excess and limiting water. Journal of Polymer Science Part B: Polymer Physics, 31(9), 1197-1203.

Cameron, R. E., \& Donald, A. M. (1993b). A small-angle X-ray scattering study of the absorption of water into the starch granule. Carbohydrate Research, 244(2), 225236.

Capron, I., Robert, P., Colonna, P., Brogly, M., \& Planchot, V. r. (2007). Starch in rubbery and glassy states by FTIR spectroscopy. Carbohydrate Polymers, 68(2), 249-259.

Carter, B. P., \& Schmidt, S. J. (2012). Developments in glass transition determination in foods using moisture sorption isotherms. Food Chemistry, 132(4), 1693-1698.

Champion, D., Le Meste, M., \& Simatos, D. (2000). Towards an improved understanding of glass transition and relaxations in foods: molecular mobility in the glass transition range. Trends in Food Science \& Technology, 11(2), 41-55.

Chung, H.-J., Chang, H.-I., \& Lim, S.-T. (2004). Physical aging of glassy normal and waxy rice starches: Effect of crystallinity on glass transition and enthalpy relaxation. Carbohydrate Polymers, 58(2), 101-107.

Chung, H.-J., Lim, H. S., \& Lim, S.-T. (2006). Effect of partial gelatinization and retrogradation on the enzymatic digestion of waxy rice starch. Journal of Cereal Science, 43(3), 353359.

Chung, H.-J., \& Lim, S.-T. (2003a). Physical aging of glassy normal and waxy rice starches: effect of aging temperature on glass transition and enthalpy relaxation. Carbohydrate Polymers, 53(2), 205-211. 


\section{References}

Chung, H.-J., \& Lim, S.-T. (2003b). Physical aging of glassy normal and waxy rice starches: effect of aging time on glass transition and enthalpy relaxation. Food Hydrocolloids, 17(6), 855-861.

Chung, H.-J., \& Lim, S.-T. (2004). Physical aging of glassy normal and waxy rice starches: thermal and mechanical characterization. Carbohydrate Polymers, 57(1), 15-21.

Collado, L. S., \& Corke, H. (1999). Heat-moisture treatment effects on sweetpotato starches differing in amylose content. Food Chemistry, 65(3), 339-346.

Conde-Petit, B., Escher, F., \& Nuessli, J. (2006). Structural features of starch-flavor complexation in food model systems. Trends in Food Science \& Technology, 17(5), 227-235.

Copeland, L., Blazek, J., Salman, H., \& Tang, M. C. (2009). Form and functionality of starch. Food Hydrocolloids, 23(6), 1527-1534.

Covarrubias-Cervantes, M., Bongard, S., Champion, D., \& Voilley, A. (2005a). Effects of the nature and concentration of substrates in aqueous solutions on the solubility of aroma compounds. Flavour and Fragrance Journal, 20(3), 265-273.

Covarrubias-Cervantes, M., Bongard, S., Champion, D., \& Voilley, A. (2005b). Temperature effect on solubility of aroma compounds in various aqueous solutions. LebensmittelWissenschaft und-Technologie, 38, 371-378.

Dams, R., \& Strijckmans, K. (2001). X-Ray fluorescence spectrometry. In H. Gunzler \& A. Williams (Eds.), Structure Analysis by Diffraction (pp. 753-766). Weinheim: Wiley-VC.

Derycke, V., Vandeputte, G. E., Vermeylen, R., De Man, W., Goderis, B., Koch, M. H. J., et al. (2005). Starch gelatinization and amylose-lipid interactions during rice parboiling investigated by temperature resolved wide angle X-ray scattering and differential scanning calorimetry. Journal of Cereal Science, 42(3), 334-343.

Donovan, J. W. (1979). Phase transitions of the starch-water system. Biopolymers, 18(2), 263-275.

Druaux, C., \& Voilley, A. (1997). Effect of food composition and microstructure on volatile flavour release. Food Science \& Technology, 8, 364-368.

Edwards, M. A., Osborne, B. G., \& Henry, R. J. (2008). Effect of endosperm starch granule size distribution on milling yield in hard wheat. Journal of Cereal Science, 48(1), 180 192. 


\section{References}

Eliasson, A. C. (1980). Effect of water content on the gelatinization of wheat starch. Starch Stärke, 32(8), 270-272.

Eliasson, A. C., \& Larsson, K. (1993). Cereal in Breadmaking: A molecular colloid approach New York: Marcel Dekker.

Englyst, H. N., \& Hudson, G. J. (1996). The classification and measurement of dietary carbohydrates. Food Chemistry, 57(1), 15-21.

Escher, F. E., Nuessli, J., \& Conde-Petit, B. (2000). Interaction of flavour compounds with starch in food processing. In D. D. Roberts \& A. J. Taylor (Eds.), Flavour release (pp. 230-245). Washington DC: American Chemical Society Symposium Series 763.

Fanta, G. F., Shogren, R. L., \& Salch, J. H. (1999). Steam jet cooking of high-amylose starchfatty acid mixtures. An investigation of complex formation1. Carbohydrate Polymers, 38(1), 1-6.

FAO. (1998). Carbohydrate in Human Food Nutrition. Rome: Agricultural and Human Protection.

Flores-Morales, A., Jiménez-Estrada, M., \& Mora-Escobedo, R. (2012). Determination of the structural changes by FT-IR, Raman, and CP/MAS 13C NMR spectroscopy on retrograded starch of maize tortillas. Carbohydrate Polymers, 87(1), 61-68.

Frost, K., Kaminski, D., Kirwan, G., Lascaris, E., \& Shanks, R. (2009). Crystallinity and structure of starch using wide angle X-ray scattering. Carbohydrate Polymers, 78(3), 543-548.

Gallant, D. J., Bouchet, B., \& Baldwin, P. M. (1997). Microscopy of starch: evidence of a new level of granule organization. Carbohydrate Polymers, 32(3-4), 177-191.

Gharsallaoui, A., Roudaut, G. I., Beney, L., Chambin, O., Voilley, A. e., \& Saurel, R. m. (2012).

Properties of spray-dried food flavours microencapsulated with two-layered membranes: Roles of interfacial interactions and water. Food Chemistry, 132(4), 1713-1720.

Glatter, O., \& Kratky, O. (Eds.). (1982). Small Angle X-ray Scattering. London: Academic Press.

Godet, M. C., Bizot, H., \& Buléon, A. (1995). Crystallization of amylose-fatty acid complexes prepared with different amylose chain lengths. Carbohydrate Polymers, 27(1), 47-52.

Gomes, A. M. M., Mendes da Silva, C. E., \& Ricardo, N. g. M. P. S. (2005). Effects of annealing on the physicochemical properties of fermented cassava starch (polvilho azedo). Carbohydrate Polymers, 60(1), 1-6. 


\section{References}

Goñi, I., García-Diz, L., Mañas, E., \& Saura-Calixto, F. (1996). Analysis of resistant starch: a method for foods and food products. Food Chemistry, 56(4), 445-449.

Gunaratne, A., \& Hoover, R. (2002). Effect of heat-moisture treatment on the structure and physicochemical properties of tuber and root starches. Carbohydrate Polymers, 49(4), 425-437.

Harrison, M., \& Hills, B. P. (1997). Mathematical model of flavor release from liquids containing aroma-binding macromolecules. Journal of Agricultural and Food Chemistry, 45(5), 1883-1890.

Hau, M. Y. M., Gray, D. A., \& Taylor, A. J. (1998). Binding of volatiles to extruded starch at low water contents. Flavour and Fragrance Journal, 13(2), 77-84.

Heinemann, C., Conde-Petit, B., Nuessli, J., \& Escher, F. (2001). Evidence of starch inclusion complexation with Lactones. Journal of Agricultural and Food Chemistry, 49(3), 13701376.

Heinemann, C., Escher, F., \& Conde-Petit, B. (2003). Structural features of starch-lactone inclusion complexes in aqueous potato starch dispersions: the role of amylose and amylopectin. Carbohydrate Polymers, 51(2), 159-168.

Heinemann, C., Zinsli, M., Renggli, A., Escher, F., \& Conde-Petit, B. (2005). Influence of amylose-flavor complexation on build-up and breakdown of starch structures in aqueous food model systems. LWT - Food Science and Technology, 38(8), 885-894.

Hernandez-Jaimes, C., Bello-Pérez, L. A., Vernon-Carter, E. J., \& Alvarez-Ramirez, J. (2013). Plantain starch granules morphology, crystallinity, structure transition, and size evolution upon acid hydrolysis. Carbohydrate Polymers, 95(1), 207-213.

Holm, J., Lundquist, I., Björck, I., Eliasson, A. C., \& Asp, N. G. (1988). Degree of starch gelatinization, digestion rate of starch in vitro, and metabolic response in rats. The American Journal of Clinical Nutrition, 47(6), 1010-1016.

Huang, H.-K., Sheu, H.-S., Chuang, W.-T., Jeng, U. S., Su, A.-C., Wu, W.-R., et al. (2014). Correlated changes in structure and viscosity during gelatinization and gelation of tapioca starch granules. IUCrJ, 1(Pt 6), 418-428.

Huang, J., Chen, Z., Xu, Y., Li, H., Liu, S., Yang, D., et al. (2014). Comparison of waxy and normal potato starch remaining granules after chemical surface gelatinization: Pasting behavior and surface morphology. Carbohydrate Polymers, 102, 1001-1007. 


\section{References}

Hung, P. V., Vien, N. L., \& Lan Phi, N. T. (2016). Resistant starch improvement of rice starches under a combination of acid and heat-moisture treatments. Food Chemistry, 191, 6773.

Imberty, A., Buléon, A., Tran, V., \& Péerez, S. (1991). Recent Advances in Knowledge of Starch Structure. Starch - Stärke, 43(10), 375-384.

International Starch Institute. (2012). Starch Production. Retrieved 24/05/2012, from www.starch.dk/isi/market/index.asp

Itthisoponkul, T., Mitchell, J. R., Taylor, A. J., \& Farhat, I. A. (2007). Inclusion complexes of tapioca starch with flavour compounds. Carbohydrate Polymers, 69(1), 106-115.

Jacobs, H., Eerlingen, R. C., \& Delcour, J. A. (1996). Factors Affecting the Visco-Amylograph and Rapid Visco-Analyzer Evaluation of the Impact of Annealing on Starch Pasting Properties. Starch - Stärke, 48(7-8), 266-270.

Jacobs, H., Mischenko, N., Koch, M. H. J., Eerlingen, R. C., Delcour, J. A., \& Reynaers, H. (1998). Evaluation of the impact of annealing on gelatinisation at intermediate water content of wheat and potato starches: A differential scanning calorimetry and small angle X-ray scattering study. Carbohydrate Research, 306(1-2), 1-10.

Jang, J. K., \& Pyun, Y. R. (1996). Effect of moisture content on the melting of wheat starch. Starch - Stärke, 48(2), 48-51.

Jayakody, L., \& Hoover, R. (2008). Effect of annealing on the molecular structure and physicochemical properties of starches from different botanical origins - A review. Carbohydrate Polymers, 74(3), 691-703.

Jenkins, P. J., Comerson, R. E., Donald, A. M., Bras, W., Derbyshire, G. E., Mant, G. R., \& Ryan, A. J. (1994). In situ simultaneous small and wide angle x-ray scattering: A new technique to study starch gelatinization. Journal of Polymer Science Part B: Polymer Physics, 32(8), 1579-1583.

Jenkins, P. J., \& Donald, A. M. (1996). Application of small-angle neutron scattering to the study of the structure of starch granules. Polymer, 37(25), 5559-5568.

Jenkins, P. J., \& Donald, A. M. (1998). Gelatinisation of starch: a combined SAXS/WAXS/DSC and SANS study. Carbohydrate Research, 308(15), 133-147.

Ji, N., Li, X., Qiu, C., Li, G., Sun, Q., \& Xiong, L. (2015). Effects of heat moisture treatment on the physicochemical properties of starch nanoparticles. Carbohydrate Polymers, 117(0), 605-609. 


\section{References}

Jiranuntakul, W., Puttanlek, C., Rungsardthong, V., Puncha-Arnon, S., \& Uttapap, D. (2011). Microstructural and physicochemical properties of heat-moisture treated waxy and normal starches. Journal of Food Engineering, 104(2), 246-258.

Jiranuntakul, W., Sugiyama, S., Tsukamoto, K., Puttanlek, C., Rungsardthong, V., Punchaarnon, S., et al. (2013). Nano-structure of heat-moisture treated waxy and normal starches. Carbohydrate Polymers, 97(1), 1-8.

Jørgensen, A. D., Jensen, S. L., Ziegler, G., Pandeya, A., Buléon, A., Svensson, B., \& Blennow, A. (2012). Structural and physical effects of aroma compound binding to native starch granules. Starch - Stärke, 64(6), 461-469.

Jouquand, C., Ducruet, V., \& Giampaoli, P. (2004). Partition coefficients of aroma compounds in polysaccharide solutions by the phase ratio variation method. Food Chemistry, 85(3), 467-474.

Jouquand, C., Ducruet, V., \& Le Bail, P. (2006). Formation of amylose complexes with C6aroma compounds in starch dispersions and its impact on retention. Food Chemistry, 96(3), 461-470.

Juansang, J., Puttanlek, C., Rungsardthong, V., Puncha-arnon, S., Jiranuntakul, W., \& Uttapap, D. (2015). Pasting properties of heat-moisture treated canna starches using different plasticizers during treatment. Carbohydrate Polymers, 122, 152-159.

Kacurakova, M., \& Wilson, R. H. (2001). Developments in mid-infrared FT-IR spectroscopy of selected carbohydrates. Carbohydrate Polymers, 44(4), 291-303.

Kalapakdee, A., \& Amornsakchai, T. (2014). Mechanical properties of referentially aligned short pineapple leaf fiber reinforced thermoplastic elastomer: effects of fiber content and matrix orientation. Polymer Testing.

Karkalas, J., Ma, S., Morrison, W. R., \& Pethrick, R. A. (1995). Some factors determining the thermal properties of amylose inclusion complexes with fatty acids. Carbohydrate Research, 268(2), 233-247.

Kasapis, S. (2012). Relation between the structure of matrices and their mechanical relaxation mechanisms during the glass transition of biomaterials: A review. Food Hydrocolloids, 26(2), 464-472.

Kaur, B., Ariffin, F., Bhat, R., \& Karim, A. A. (2012). Progress in starch modification in the last decade. Food Hydrocolloids, 26(2), 398-404. 


\section{References}

Kawai, K., Takato, S., Sasaki, T., \& Kajiwara, K. (2012). Complex formation, thermal properties, and in-vitro digestibility of gelatinized potato starch-fatty acid mixtures. Food Hydrocolloids, 27(1), 228-234.

Kersiene, M., Adams, A., Dubra, A., Kimpe, N. D., \& Leskauskaite-, D. (2008). Interactions between flavour release and rheological properties in model custard desserts: Effect of starch concentration and milk fat. Food Chemistry, 108(4), 1183-1191.

Kim, H.-S., \& Huber, K. C. (2008). Channels within soft wheat starch A- and B-type granules. Journal of Cereal Science, 48(1), 159-172.

Kim, H.-S., \& Huber, K. C. (2010a). Impact of A/B-type granule ratio on reactivity, swelling, gelatinization, and pasting properties of modified wheat starch. Part I: Hydroxypropylation. Carbohydrate Polymers, 80(1), 94-104.

Kim, H.-S., \& Huber, K. C. (2010b). Physicochemical properties and amylopectin fine structures of A- and B-type granules of waxy and normal soft wheat starch. Journal of Cereal Science, 51(3), 256-264.

Kohyama, K., Matsuki, J., Yasui, T., \& Sasaki, T. (2004). A differential thermal analysis of the gelatinization and retrogradation of wheat starches with different amylopectin chain lengths. Carbohydrate Polymers, 58(1), 71-77.

Lan, H., Hoover, R., Jayakody, L., Liu, Q., Donner, E., Baga, M., Asare, E.K., Hucl, P. \& Chibbar, R.N. (2008). Impact of annealing on the molecular structure and physicochemical properties of normal, waxy and high amylose bread wheat starches. Food Chemistry, 111(3), 663-675.

Lay Ma, U. V., Floros, J. D., \& Ziegler, G. R. (2011). Formation of inclusion complexes of starch with fatty acid esters of bioactive compounds. Carbohydrate Polymers, 83(4), 1869-1878.

Le Bail, P., Rondeau, C., \& Buleon, A. (2005). Structural investigation of amylose complexes with small ligands: helical conformation, crystalline structure and thermostability. International Journal of Biological Macromolecules, 35(1-2), 1-7.

Le Meste, M., Champion, D., Roudaut, G., Blond, G., \& Simatos, D. (2002). Glass Transition and Food Technology: A Critical Appraisal. Journal of Food Science, 67(7), 2444-2458.

Le Thanh, M., Thibeaudeau, P., Thibaut, M. A., \& Voilley, A. (1992). Interactions between volatile and non-volatile compounds in the presence of water. Food Chemistry, 43(2), 129-135. 


\section{References}

Lebail, P., Buleon, A., Shiftan, D., \& Marchessault, R. H. (2000). Mobility of lipid in complexes of amylose-fatty acids by deuterium and $13 \mathrm{C}$ solid state NMR. Carbohydrate Polymers, 43(4), 317-326.

Li, S., Ward, R., \& Gao, Q. (2011). Effect of heat-moisture treatment on the formation and physicochemical properties of resistant starch from mung bean (Phaseolus radiatus) starch. Food Hydrocolloids, 25(7), 1702-1709.

Li, W.-y., Yan, S.-h., Yin, Y.-p., Li, Y., Liang, T.-b., Gu, F., et al. (2008). Comparison of Starch Granule Size Distribution Between Hard and Soft Wheat Cultivars in Eastern China. Agricultural Sciences in China, 7(8), 907-914.

Lindeboom, N., Chang, P. R., \& Tyler, R. T. (2004). Analytical, biochemical and physicochemical aspects of starch granule size, with emphasis on small granule starches: a review. Starch - Stärke, 56(3-4), 89-99.

Lindsay, R. C. (1996). Food Chemistry. In O. R. Fennema (Ed.), (3rd ed., pp. 157-223): Marcel Dekker.

Lopez-Rubio, A., \& Gilbert, E. P. (2009). Neutron scattering: a natural tool for food science and technology research. Trends in Food Science \& Technology, 20(11-12), 576-586.

Lubbers, S., \& Butler, E. (2010). Effects of texture and temperature on the kinetic of aroma release from model dairy custards. Food Chemistry, 123(2), 345-350.

Maache-Rezzoug, Z., Zarguili, I., Loisel, C., Queveau, D., \& Buleon, A. (2008). Structural modifications and thermal transitions of standard maize starch after DIC hydrothermal treatment. Carbohydrate Polymers, 74(4), 802-812.

Madene, A., Jacquot, M., Scher, J., \& Desobry, S. (2006). Flavour encapsulation and controlled release - a review. International Journal of Food Science \& Technology, 41(1), 1-21.

Mahasukhonthachat, K., Sopade, P. A., \& Gidley, M. J. (2010). Kinetics of starch digestion in sorghum as affected by particle size. Journal of Food Engineering, 96(1), 18-28.

Malumba, P., Jacquet, N., Delimme, G., Lefebvre, F., \& Béra, F. (2013). The swelling behaviour of wheat starch granules during isothermal and non-isothermal treatments. Journal of Food Engineering, 114(2), 199-206.

Marchant, J. L., \& Blanshard, J. M. V. (1978). Studies of the Dynamics of the Gelatinization of Starch Granules Employing a Small Angle Light Scattering System. Starch - Stärke, $30(8), 257-264$. 


\section{References}

Martuscelli, M., Savary, G. r., Pittia, P., \& Cayot, N. (2008). Vapour partition of aroma compounds in strawberry flavoured custard cream and effect of fat content. Food Chemistry, 108(4), 1200-1207.

Mason, W. R. (2009). Starch Use in Foods. In J. BeMiller \& R. Whistler (Eds.), Starch: Chemistry and Technology (3rd ed., pp. 745-796). New York: Academic Press.

Morris, C., Taylor, A. J., Farhat, I. A., \& MacNaughtan, W. (2011). Modelling of physical ageing in starch using the TNM equation. Carbohydrate Research, 346(9), 1122-1128.

Murua-Pagola, B., Beristain-Guevara, C. I., \& Martinez-Bustos, F. (2009). Preparation of starch derivatives using reactive extrusion and evaluation of modified starches as shell materials for encapsulation of flavoring agents by spray drying. Journal of Food Engineering, 91(3), 380-386.

Naguleswaran, S., Li, J., Vasanthan, T., Bressler, D., \& Hoover, R. (2012). Amylolysis of large and small granules of native triticale, wheat and corn starches using a mixture of $\alpha$ amylase and glucoamylase. Carbohydrate Polymers, 88(3), 864-874.

Nakazawa, F., Noguchi, S., Takahashi, J., \& Takada, M. (1984). Thermal equilibrium state of starch-water mixture studied by differential scanning calorimetry. Agricultural and Biological Chemistry, 48(11), 2647-2653.

Nuessli, J., Conde-Petit, B., Trommsdorff, U. R., \& Escher, F. (1995). Influence of starch flavour interactions on rheological properties of low concentration starch systems. Carbohydrate Polymers, 28(2), 167-170.

Nuessli, J., Putaux, J. L., Le Bail, P., \& Buléon, A. (2003). Crystal structure of amylose complexes with small ligands. International Journal of Biological Macromolecules, 33(4-5), 227-234.

Nuessli, J., Sigg, B., Conde-Petit, B., \& Escher, F. (1997). Characterization of amylose-flavour complexes by DSC and X-ray diffraction. Food Hydrocolloids, 11(1), 27-34.

Oostergetel, G. T., \& van Bruggen, E. F. J. (1993). The crystalline domains in potato starch granules are arranged in a helical fashion. Carbohydrate Polymers, 21(1), 7-12.

Patel, B. K., \& Seetharaman, K. (2006). Effect of heating rate on starch granule morphology and size. Carbohydrate Polymers, 65(3), 381-385.

Paulus, E. F., \& Gieren, A. (2001). Structure Analysis by Diffraction. In H. Gunzler \& A. Williams (Eds.), Handbook of Analytical Techniques (pp. 373-417). Weinheim: WileyVC. 


\section{References}

Penner, M. H. (2010). Basic principle of spectroscopy. In S. S. Nielsen (Ed.), Food Analysis (4th ed.). West Lafayette: Springer Science.

Pérez, S., Baldwin, P. M., \& Gallant, D. J. (2009). Structural Features of Starch Granules I. In J. BeMiller \& R. Whistler (Eds.), Starch: Chemistry and Technology (3rd ed., pp. 149192). New York: Academic Press.

Pérez, S., \& Bertoft, E. (2010). The molecular structures of starch components and their contribution to the architecture of starch granules: A comprehensive review. Starch Stärke, 62(8), 389-420.

Pikus, S. (2005). Small-Angle X-Ray Scattering (SAXS) studies of the structure of starch and starch products. Fibres \& Textiles in Eastern Europe, $13(5$ (53)), 82-86.

Poirier-Brulez, F., Roudaut, G., Champion, D., Tanguy, M., \& Simatos, D. (2006). Influence of sucrose and water content on molecular mobilityin starch-based glasses as assessed through structureand secondary relaxation. Biopolymers, 81(2), 63-73.

Popov, D., Buléon, A., Burghammer, M., Chanzy, H., Montesanti, N., Putaux, J. L., PotockiVéronèse, G. \& Riekel, C. . (2009). Crystal structure of A-amylose: a revisit from synchrotron microdiffraction analysis ofsingle crystals. Macromolecules, 42(4), 11671174.

Pozo-Bayon, M. A., Biais, B. , Rampon, V., Cayot, N., \& Le Bail, P. (2008). Influence of complexation between amylose and a flavored model sponge cake on the degree of aroma compound release. Journal of Agricultural and Food Chemistry, 56(15), 66406647.

Pozo-Bayon, M. A., Guichard, E., \& Cayot, N. (2006). Flavor control in baked cereal products. Food Reviews International, 22(4), 335-379.

Preininger, M. (2006). Interactions of flavour components in foods. In A. G. Gaonkar \& A. McPherson (Eds.), Ingredient Interactions: Effects on Food Quality (2nd ed., pp. 477542). Florida: CRC Press.

Preiss, J. (2009). Biochemistry and molecular biology of starch biosynthesis. In J. BeMiller \& R. Whistler (Eds.), Starch: Chemistry and Technology (3rd ed., pp. 83-148). New York: Academic Press.

Putseys, J. A., Lamberts, L., \& Delcour, J. A. (2010). Amylose-inclusion complexes: Formation, identity and physico-chemical properties. Journal of Cereal Science, 51(3), 238-247. 


\section{References}

Rahmouni, M., Chouinard, F., Nekka, F., Lenaerts, V., \& Leroux, J. C. (2001). Enzymatic degradation of cross-linked high amylose starch tablets and its effect on in vitro release of sodium diclofenac. European Journal of Pharmaceutics and Biopharmaceutics, 51(3), 191-198.

Rarm, P., Siriwat, S., Prae, C., Jitrin, C., Wutthikrai, B., Surachai, P., Supanan, L.; \& Supagorn, R. (2013). SAXS/WAXS Capability and absolute intensity measurement study at the SAXS beamline of the Siam Photon Laboratory. Journal of Physics: Conference Series, 425(13), 132019.

Ratnayake, W. S., \& Jackson, D. S. (2007). A new insight into the gelatinization process of native starches. Carbohydrate Polymers, 67(4), 511-529.

Ratnayake, W. S., Jackson, D. S., \& Steve, L. T. (2008). Starch Gelatinization Advances in Food and Nutrition Research (Vol. 55, pp. 221-268): Academic Press.

Ratnayake, W. S., Otani, C., \& Jackson, D. S. (2009). DSC enthalpic transitions during starch gelatinisation in excess water, dilute sodium chloride and dilute sucrose solutions. Journal of the Science of Food and Agriculture, 89(12), 2156-2164.

Rawle, A. (2002). The importance of particle sizing to the coating industry Part 1: Particle size measurment. Advances in Colour Science and Technology, 5(1), 1-12.

Rawle, A. (n.d.). Technical pater: Basic principles of particle size analysis. Retrieved 24/02/2015, from www.malvern.co.uk

Rodríguez, S. D., \& Bernik, D. L. (2014). Flavor release by enzymatic hydrolysis of starch samples containing vanillin-amylose inclusion complexes. LWT - Food Science and Technology, 59(2, Part 1), 635-640.

Rolée, A., \& Le Meste, M. (1999). Effect of Moisture Content on Thermomechanical Behavior of Concentrated Wheat Starch-Water Preparations. Cereal Chemistry Journal, 76(3), 452-458.

Rolée, A., \& Le Meste, M. (1997). Thermomechanical Behavior of Concentrated StarchWater Preparations. Cereal Chemistry Journal, 74(5), 581-588.

Rondeau-Mouro, C., Le Bail, P., \& Buléon, A. (2004). Structural investigation of amylose complexes with small ligands: inter- or intra-helical associations? International Journal of Biological Macromolecules, 34(5), 251-257.

Roos, Y. (1995). Phase Transitions in Foods. California: Academic Press. 


\section{References}

Roos, Y. (2010). Glass transition temperature and its relevance in food processing. Annual Review of Food Science and Technology, 1(1), 469-496.

Roos, Y. H. (2007). Water activity and glass Transition. In G. V. Barbosa-Cánovas, A. J. Fontana Jr, S. J. Schmidt \& T. P. Labuza (Eds.), Water Activity in Foods: Fundamentals and Applications (pp. 29-46). Oxford: Blackwell Publishing.

Roudaut, G., Dacremont, C., Vallès Pàmies, B., Colas, B., \& Le Meste, M. (2002). Crispness: a critical review on sensory and material science approaches. Trends in Food Science \& Technology, 13(6-7), 217-227.

Roudaut, G., Simatos, D., Champion, D., Contreras-Lopez, E., \& Le Meste, M. (2004). Molecular mobility around the glass transition temperature: a mini review. Innovative Food Science \& Emerging Technologies, 5(2), 127-134.

Rowe, D. J. (2005). Introduction. In D. Rowe (Ed.), Chemistry and Technology of Flavour and Fragrances (pp. 1-11). Oxford: Blackwell.

Sablani, S. S. (2009). Gelatinization of starch. In M. S. Rahman (Ed.), Food Properties Hanbook (2nd ed., pp. 287-322). Florida: CRC Press.

Sablani, S. S., Kasapis, S., \& Rahman, M. S. (2007). Evaluating water activity and glass transition concepts for food stability. Journal of Food Engineering, 78(1), 266-271.

Saibene, D., \& Seetharaman, K. (2008). Use of lodine as a Tool to Understand Wheat Starch Pasting Properties. Starch - Stärke, 60(1), 1-7.

Sajilata, M. G., \& Singhal, R. S. (2005). Specialty starches for snack foods. Carbohydrate Polymers, 59(2), 131-151.

Salman, H., Blazek, J., Lopez-Rubio, A., Gilbert, E. P., Hanley, T., \& Copeland, L. (2009). Structure-function relationships in A and B granules from wheat starches of similar amylose content. Carbohydrate Polymers, 75(3), 420-427.

Sasaki, T., Yasui, T., \& Matsuki, J. (2000). Effect of amylose content on gelatinization, retrogradation, and pasting properties of starches from waxy and nonwaxy wheat and their F1 seeds. Cereal Chemistry Journal, 77(1), 58-63.

Savary, G., Lafarge, C., Doublier, J.-L., \& Cayot, N. (2007). Distribution of aroma in a starchpolysaccharide composite gel. Food Research International, 40(6), 709-716.

Schwartz, D., \& Whistler, R. L. (2009). History and future of starch. In J. BeMiller, R. Whistler \& (Eds.), Starch: Chemistry and Technology (3rd ed., pp. 1-10). New York: Academic Press. 


\section{References}

Seuvre, A.-M., Philippe, E., Rochard, S., \& Voilley, A. (2006). Retention of aroma compounds in food matrices of similar rheological behaviour and different compositions. Food Chemistry, 96(1), 104-114.

Sevenou, O., Hill, S. E., Farhat, I. A., \& Mitchell, J. R. (2002). Organisation of the external region of the starch granule as determined by infrared spectroscopy. International Journal of Biological Macromolecules, 31(1-3), 79-85.

Singh, J., Kaur, L., \& McCarthy, O. J. (2007). Factors influencing the physico-chemical, morphological, thermal and rheological properties of some chemically modified starches for food applications-A review. Food Hydrocolloids, 21(1), 1-22.

Smits, A. L. M., Ruhnau, F. C., Vliegenthart, J. F. G., \& van Soest, J. J. G. (1998). Ageing of starch based systems as observed with FT-IR and solid state NMR spectroscopy. Starch - Stärke, 50(11-12), 478-483.

Soontaranon, S., \& Rugmai, S. (2012). Small angle X-ray scattering at Siam Photo Laboratory. Chinese Journal of Physics, 50(2), 204-210.

Sujka, M., \& Jamroz, J. (2013). Ultrasound-treated starch: SEM and TEM imaging, and functional behaviour. Food Hydrocolloids, 31(2), 413-419.

Sun, Q., Dai, L., Nan, C., \& Xiong, L. (2014). Effect of heat moisture treatment on physicochemical and morphological properties of wheat starch and xylitol mixture. Food Chemistry, 143(0), 54-59.

Sun, Y., Wu, Z., Hu, B., Wang, W., Ye, H., Sun, Y., Wang, X., \& Zeng, X. (2014). A new method for determining the relative crystallinity of chickpea starch by Fourier-transform infrared spectroscopy. Carbohydrate Polymers, 108(0), 153-158.

Tang, H., Mitsunaga, T., \& Kawamura, Y. (2006). Molecular arrangement in blocklets and starch granule architecture. Carbohydrate Polymers, 63(4), 555-560.

Tang, M. C., \& Copeland, L. (2007). Analysis of complexes between lipids and wheat starch. Carbohydrate Polymers, 67(1), 80-85.

Taylor, A. J. (1998). Physical chemistry of flavour. International Journal of Food Science \& Technology, 33(1), 53-62.

Tester, R., \& Debon, S. (2000). Annealing of starch - a review. International Journal of Biological Macromolecules, 27(1), 1-12.

Tester, R., Karkalas, J., \& Qi, X. (2004). Starch-composition, fine structure and architecture. Journal of Cereal Science, 39(2), 151-165. 


\section{References}

Tester, R. F., Debon, S. J. J., \& Karkalas, J. (1998). Annealing of wheat starch. Journal of Cereal Science, 28(3), 259-272.

Tester, R. F., \& Morrison, W. R. (1990). Swelling and gelatinization of cereal starches. I. Effects of amylopectin, amylose, and lipids. Cereal Chemistry Journal, 67(6), 551-557.

Tester, R. F., Morrison, W. R., Ellis, R. H., Piggot, J. R., Batts, G. R., Wheeler, T. R., et al. (1995). Effects of elevated growth temperature and carbon dioxide levels on some physicochemical properties wheat starch. Journal of Cereal Science, 22, 63-71.

Tester, R. F., Qi, X., \& Karkalas, J. (2006). Hydrolysis of native starches with amylases. Animal Feed Science and Technology, 130(1-2), 39-54.

Ubbink, J., \& Krüger, J. (2006). Physical approaches for the delivery of active ingredients in foods. Trends in Food Science \& Technology, 17(5), 244-254.

Ubbink, J., \& Mezzenga, R. (2006). Delivery of functionality in complex food systems: introduction. Trends in Food Science \& Technology, 17(5), 194-195.

Van Ruth, S. M., O'Connor, C. H., \& Delahunty, C. M. (2000). Relationships between temporal release of aroma compounds in a model mouth system and their physicochemical characteristics. Food Chemistry, 71, 393-399.

Van Ruth, S. M., \& Roozen, J. P. (2010). Delivery of flavours from food matrices. In A. J. Taylor \& R. S. T. Linforth (Eds.), Food Flavour Technology (2nd ed., pp. 190-206). West Sussex: Wiley-Blackwell.

Vermeylen, R., Derycke, V., Delcour, J. A., Goderis, B., Reynaers, H., \& Koch, M. H. J. (2006). Gelatinization of starch in excess water: beyond the melting of lamellar crystallites. A combined wide- and small-angle X-ray scattering study. Biomacromolecules, 7(9), 2624-2630.

Vermeylen, R., Goderis, B., \& Delcour, J. A. (2006). An X-ray study of hydrothermally treated potato starch. Carbohydrate Polymers, 64(2), 364-375.

Vermeylen, R., Goderis, B., Reynaers, H., \& Delcour, J. A. (2004). Amylopectin molecular structure reflected in macromolecular organization of granular starch. Biomacromolecules, 5(5), 1775-1786.

Vermeylen, R., Goderis, B., Reynaers, H., \& Delcour, J. A. (2005). Gelatinisation related structural aspects of small and large wheat starch granules. Carbohydrate Polymers, 62(2), 170-181. 


\section{References}

Waduge, R. N., Hoover, R., Vasanthan, T., Gao, J., \& Li, J. (2006). Effect of annealing on the structure and physicochemical properties of barley starches of varying amylose content. Food Research International, 39(1), 59-77.

Waigh, T. A., Gidley, M. J., Komanshek, B. U., \& Donald, A. M. (2000). The phase transformations in starch during gelatinisation: a liquid crystalline approach. Carbohydrate Research, 328(2), 165-176.

Waigh, T. A., Hopkinson, I., Donald, A. M., Butler, M. F., Heidelbach, F., \& Riekel, C. (1997). Analysis of the native structure of starch granules with X-ray microfocus diffraction. Macromolecules, 30(13), 3813-3820.

Waigh, T. A., Kato, K. L., Donald, A. M., Gidley, M. J., Clarke, C. J., \& Riekel, C. (2000). SideChain Liquid-Crystalline Model for Starch. Starch - Stärke, 52(12), 450-460.

Warren, F. J., Royall, P. G., Gaisford, S., Butterworth, P. J., \& Ellis, P. R. (2011). Binding interactions of $\alpha$-amylase with starch granules: The influence of supramolecular structure and surface area. Carbohydrate Polymers, 86(2), 1038-1047.

Williams, D. B., \& Carter, C. B. (2009). Scattering and diffraction. In D. B. Williams \& C. B. Carter (Eds.), Transmission Electron Microscopy: A Textbook for Materials Science (pp. 23-38). West Lafayette: Springer Science.

Wilson, R. H. (1990). Fourier transform mid-infrared spectroscopy for food analysis. Trends in Analytical Chemistry, 9(4), 127-131.

Wilson, R. H., \& Tapp, H. S. (1999). Mid-infrared spectroscopy for food analysis: recent new applications and relevant developments in sample presentation methods. Trends in Analytical Chemistry, 18(2), 85-93.

Windholz, M., Budavari, S., Blumetti, R. F., \& Otterbein, E. S. (Eds.). (1983). The Merck Index: An Encyclopedia of Chemicals, Drugs, and Biologicals (10th ed.). Rahway, NJ: Merck

Winkel, C. (2005). Stability of aroma chemicals In D. Rowe (Ed.), Chemistry and Technology of Flavour and Fragrances (pp. 244-260). Oxford: Blackwell.

Wulff, G., Avgenaki, G., \& Guzmann, M. S. P. (2005). Molecular encapsulation of flavours as helical inclusion complexes of amylose. Journal of Cereal Science, 41(3), 239-249.

Wulff, G., Steinert, A., \& Höller, O. (1998). Modification of amylose and investigation of its inclusion behavior. Carbohydrate Research, 307(1-2), 19-31.

Zasypkin, D., \& Porzio, M. (2004). Glass encapsulation of flavours with chemically modified starch blends. Journal of Microencapsulation, 21(4), 385-397. 


\section{References}

Zavareze, E. d. R., \& Dias, A. R. G. (2011). Impact of heat-moisture treatment and annealing in starches: A review. Carbohydrate Polymers, 83(2), 317-328.

Zeleznak, K. J., \& Hoseney, R. C. (1987). The glass transition in starch. Cereal Chemistry Journal, 64(2), 121-124.

Zhu, T., Jackson, D. S., Wehling, R. L., \& Geera, B. (2008). Comparison of amylose determination methods and the development of a dual wavelength iodine binding technique 1. Cereal Chemistry Journal, 85(1), 51-58.

Zimonja, O., \& Svihus, B. (2009). Effects of processing of wheat or oats starch on physical pellet quality and nutritional value for broilers. Animal Feed Science and Technology, 149(3-4), 287-297.

Zobel, H. F., Young, S. N., \& Rocca, L. A. (1988). Starch gelatinization : an X-ray diffraction study. Cereal Chemistry Journal, 65(6), 443-446.

Zuckerforschung Tulln, G. (2012). Starch Technology - Statistics. Retrieved 24/05/2012, from www.zuckerforschung.at/inhalt_en.php?titel=STARCH\%20TECHNOLOGY\&nav= nstaerkeinfo_en\&con=cist_en 
Appendix 
Appendix 1: SPME results

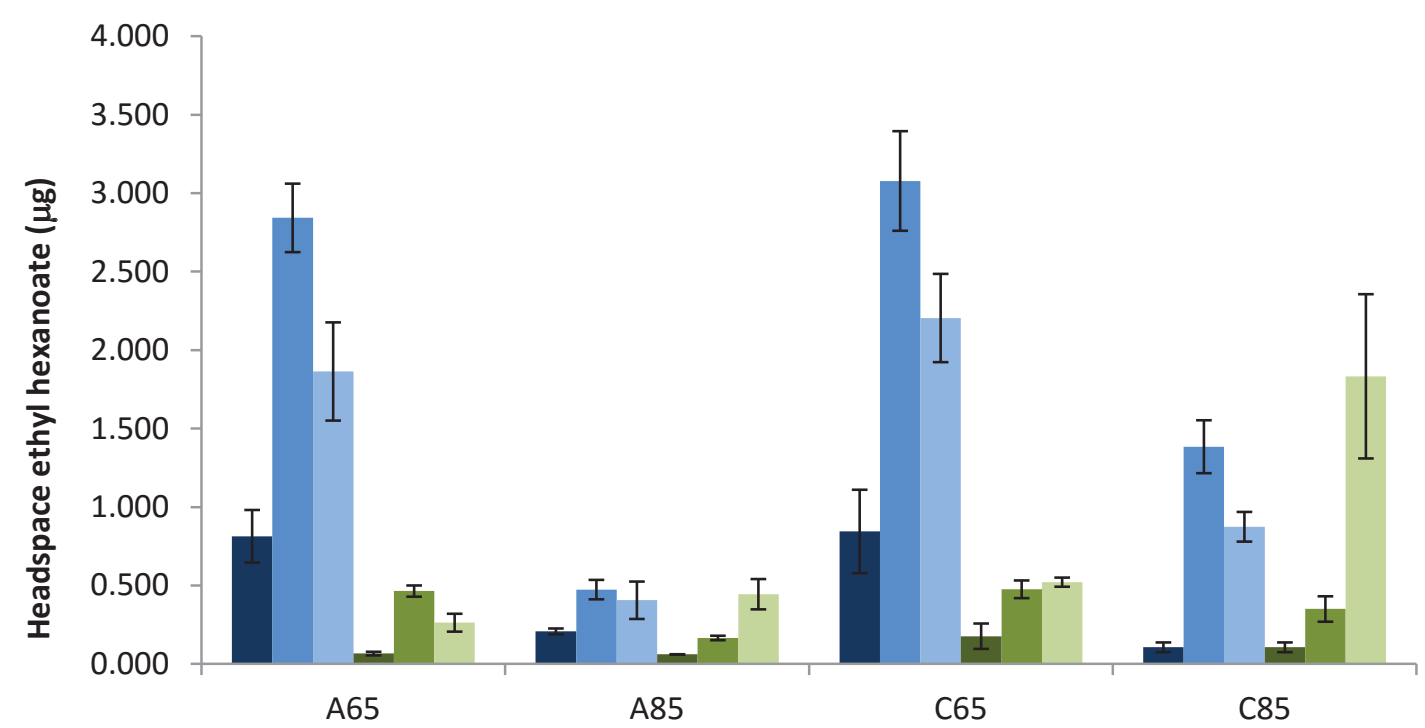

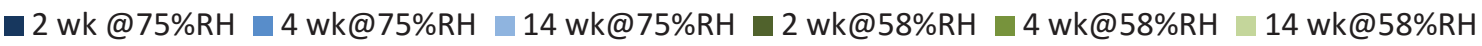

Figure A-1: Extracted amount of ethyl hexanoate by SPME in $\mu \mathrm{g}$ unit

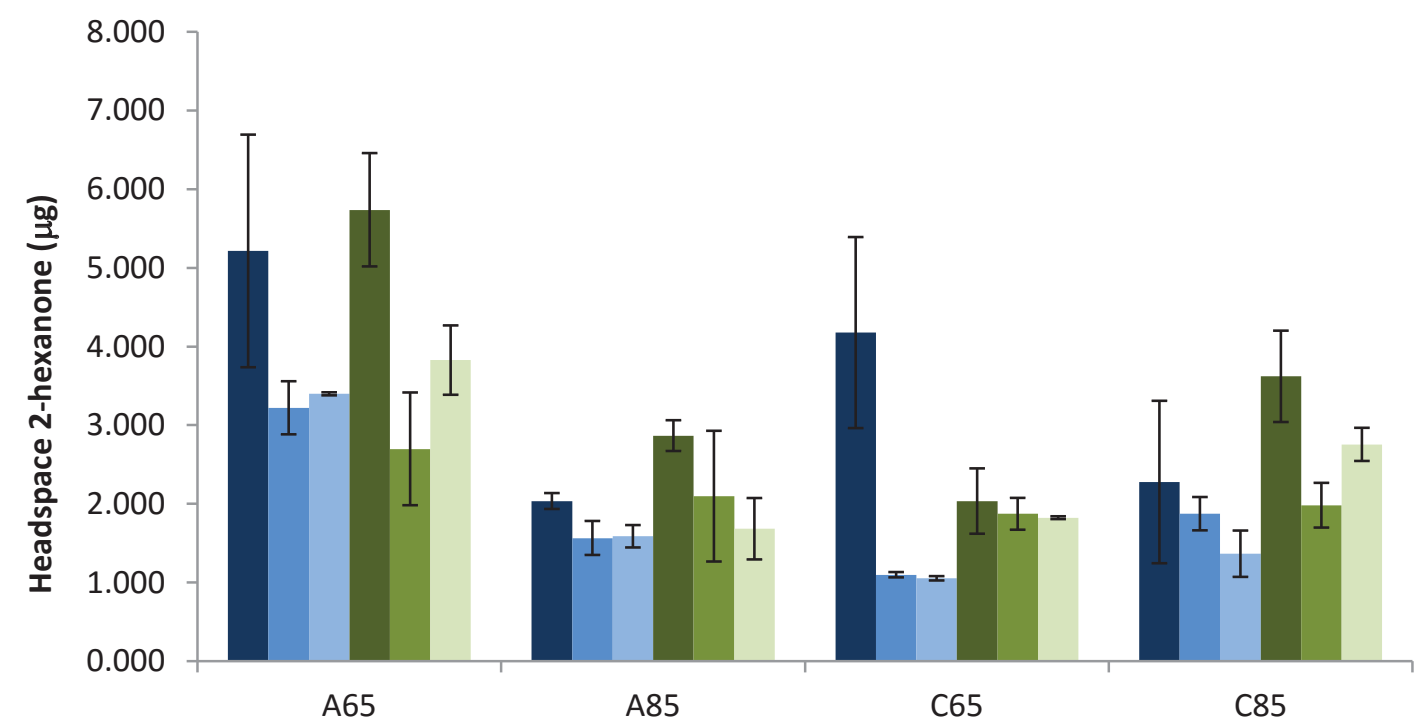

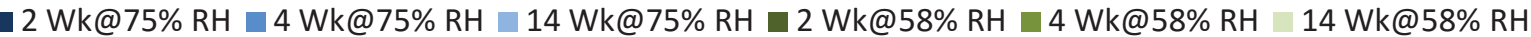

Figure A-2: Extracted amount of 2-hexanone by SPME in $\mu$ g unit 


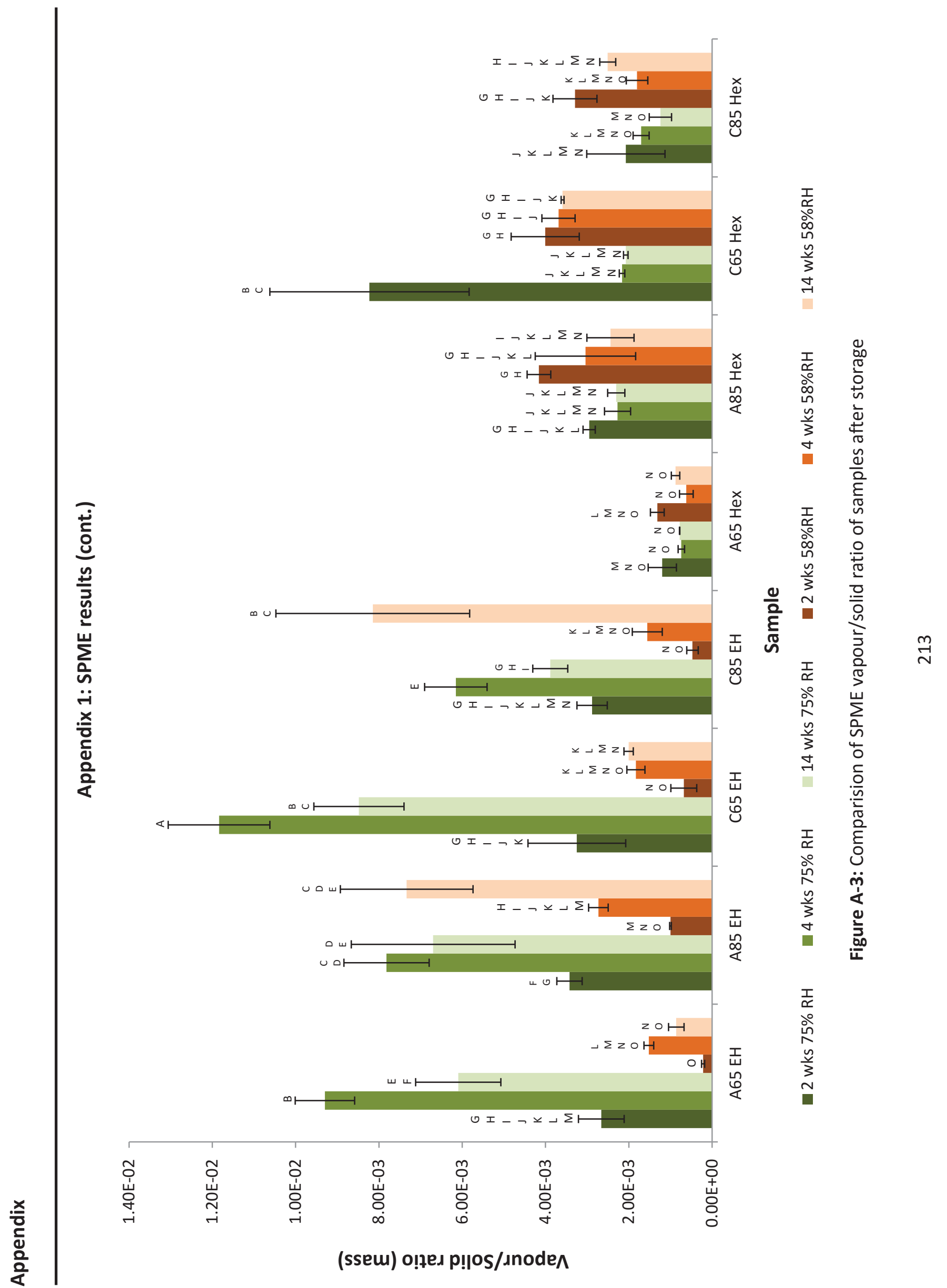




\section{Appendix 1: SPME results (cont.)}

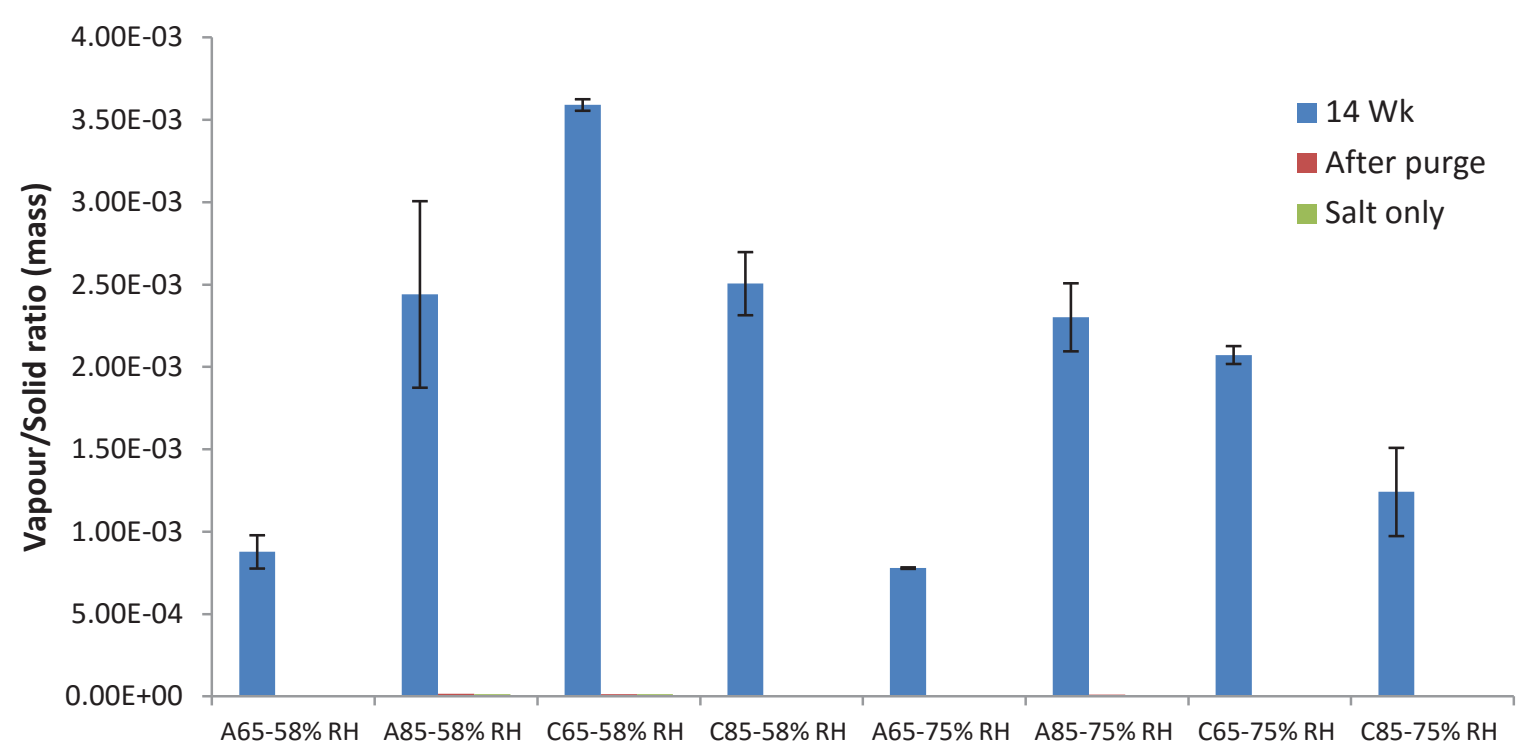

Sample vs \%RH

Figure A-4: Comparison of SPME vapour/solid ratio of 2-hexanone released after storage 14 weeks, after purge and in saturated salt solution

Table A-1: Residual of flavour (after purging and after one night equilibration) and retained flavour in saturated salt after 14 weeks storage

\begin{tabular}{|c|c|c|c|c|}
\hline \multirow[t]{2}{*}{ Sample } & \multirow[t]{2}{*}{ Flavour } & \multirow[t]{2}{*}{$\%$ RH } & \multicolumn{2}{|c|}{$\begin{array}{c}\text { vapour/solid } \\
\text { (\% ratio to } 14 \text { weeks storage)* }\end{array}$} \\
\hline & & & After purging** & In salt*** \\
\hline A65 & & & 161.07 & 31.18 \\
\hline A85 & Ethyl hexanoate & 58 & 40.37 & 1.34 \\
\hline C65 & & & 94.15 & 11.63 \\
\hline $\mathrm{C} 85$ & & & 9.26 & 1.62 \\
\hline A65 & & & 104.49 & 16.33 \\
\hline A85 & Ethyl hexanoate & 75 & 67.79 & 1.60 \\
\hline C65 & & & 62.75 & 4.81 \\
\hline C85 & & & 90.12 & 7.48 \\
\hline A65 & & & 0.96 & 0.53 \\
\hline A85 & 2-Hexanone & 58 & 0.65 & 0.54 \\
\hline C65 & & & 0.39 & 0.39 \\
\hline $\mathrm{C} 85$ & & & 0.22 & 0.21 \\
\hline A65 & & & 0.77 & 0.89 \\
\hline A85 & 2-Hexanone & 75 & 0.44 & 0.42 \\
\hline C65 & & & 0.43 & 0.28 \\
\hline C85 & & & 0.25 & 0.23 \\
\hline
\end{tabular}

* Percent ratio in comparison to vapour/solid ratio obtained from sample after 14 week storage

**Purged out the headspace with nitrogen gas prior, reclosed the vial and re-equilibrated overnight prior to analysis.

***The starch vials have been removed, purged with nitrogen gas, the vial reclosed, and re-equilibrated overnight prior to analysis. 


\section{Appendix 2: Glass transition results}

Table A-2: Glass transition temperature and moisture contents during storage

\begin{tabular}{|c|c|c|c|c|}
\hline \multirow[t]{2}{*}{ Sample } & \multicolumn{2}{|c|}{$\begin{array}{c}\mathrm{Tg} \\
\left({ }^{\circ} \mathrm{C} \pm \mathrm{SD}\right)\end{array}$} & \multicolumn{2}{|c|}{$\begin{array}{c}\text { Moisture content } \\
(\%)\end{array}$} \\
\hline & @ 58\% RH & @ 75\% RH & @ 58\% RH & @ 75\% RH \\
\hline A65 & $77.74 \pm 1.07$ & $61.50 \pm 0.14$ & $9.88 \pm 0.29$ & $10.78 \pm 0.52$ \\
\hline A65EH & $80.25 \pm 3.68$ & $53.07 \pm 0.74$ & $9.78 \pm 0.31$ & $9.66 \pm 2.35$ \\
\hline A65Hex ${ }^{\text {C2 }}$ & $79.24 \pm 0.92$ & $52.87 \pm 2.88$ & $11.15 \pm 1.98$ & $17.85 \pm 0.46$ \\
\hline A85 & $79.96 \pm 0.30$ & $60.24 \pm 1.27$ & $7.58 \pm 1.36$ & $10.39 \pm 0.63$ \\
\hline A85EH & $86.21 \pm 3.76$ & $56.80 \pm 3.49$ & $8.79 \pm 0.34$ & $8.97 \pm 0.17$ \\
\hline A85Hex ${ }^{\mathrm{C2}}$ & $80.68 \pm 0.50$ & $60.47 \pm 2.40$ & $11.04 \pm 1.71$ & $14.22 \pm 0.42$ \\
\hline C65 & $76.50 \pm 2.22$ & $60.96 \pm 1.17$ & $8.97 \pm 2.03$ & $12.10 \pm 0.82$ \\
\hline C65EH & $67.02 \pm 1.69$ & $67.40 \pm 0.72$ & $8.59 \pm 0.15$ & $10.19 \pm 1.21$ \\
\hline $\mathrm{C} 65 \mathrm{Hex}{ }^{\mathrm{C} 2}$ & $81.29 \pm 3.63$ & $60.41 \pm 1.54$ & $9.99 \pm 0.55$ & $12.22 \pm 1.34$ \\
\hline C85 & $80.46 \pm 0.06$ & $65.80 \pm 2.78$ & $9.80 \pm 0.89$ & $12.03 \pm 1.11$ \\
\hline C85EH & $80.20 \pm 4.49$ & $54.95 \pm 3.51$ & $10.76 \pm 1.25$ & $12.54 \pm 2.65$ \\
\hline $\mathrm{C} 85 \mathrm{Hex}^{\mathrm{C2}}$ & $80.62 \pm 0.50$ & $58.99 \pm 2.08$ & $10.23 \pm 1.16$ & $12.50 \pm 1.54$ \\
\hline
\end{tabular}




\section{List of communication and publication}




\section{Presentation}

June 14 Oral presentation in French entitled “Amidon-Eau-Arôme L'Interaction (La libération d'arômes inclus dans des matrices d'amidon et eaux)" at AgroSup, Dijon : Communication dans le cadre du séminaire "Ça bouge dans nos assiettes"

June 14 Poster presentation entitled "Water Contribution to the Structuration of Starch Matrices in the Presence of Flavour" at The $20^{\text {th }}$ Forum of Young Researchers 2014 (20 Forum des Jeunes Chercheurs 2014), Besançon, France.

May 14 Poster presentation entitle "Water Contribution to the Structuration of Starch Matrices in the Presence of Flavour" at The $8^{\text {th }}$ International Conference on Water in Food (Euro Food Water), Timişoara, Romania. (Awarded The Best Poster $3^{\text {rd }}$ Postion)

\section{Publication}

Somboonchan, S., Lubbers, S., \& Roudaut, G. (2015). Water and temperature contribution to the structuration of starch matrices in the presence of flavour. Food Chemistry. (Article in press - doi: 10.1016/j.foodchem.2015.04.099) 


\title{
Water and temperature contribution to the structuration of starch matrices in the presence of flavour
}

\author{
Silawan Somboonchan, Samuel Lubbers, Gaëlle Roudaut* \\ UMR PAM, Université de Bourgogne/AgroSup Dijon, PAPC Team, 1 Esplanade Erasme, 21000 Dijon, France
}

\section{A R T I C L E I N F O}

\section{Article history:}

Received 29 November 2014

Received in revised form 17 April 2015

Accepted 19 April 2015

Available online 23 April 2015

Chemical compounds studied in this article:

Ethyl hexanoate (PubChem CID: 31265)

2-Hexanone (PubChem CID: 11583)

Methyl heptanoate (PubChem CID: 7826)

Ethyl octanoate (PubChem CID: 7799)

Keywords:

Wheat starch

Flavour

RVA

Partial gelatinisation

\begin{abstract}
A B S T R A C T
The effect of modulating the gelatinisation extent by hydration (50/50 and 80/20 water to starch ratio) and temperature $\left(65\right.$ or $85^{\circ} \mathrm{C}$ ) on various properties of wheat starch in presence of flavours has been studied. The hydrothermal treatments resulted in samples with different properties. The lowest residual flavour content was found in samples treated at the highest hydration and temperature $\left(85^{\circ} \mathrm{C}\right)$ while the other treatment conditions led to samples with similar residual flavour content. Ethyl hexanoate significantly increased the characteristic pasting viscosities compared to starch \pm 2 -hexanone; suggesting a greater structuration with ethyl hexanoate. Heating starch in excess water caused amylopectin melting, but promoted an incomplete granular swelling as revealed by RVA. This study suggested that lowering the hydration upon treatment could limit both crystal melting (with a residual crystalline content up to $38 \%$ in the most extreme conditions) and granular swelling but increased granule organisation like following annealing.
\end{abstract}

(C) 2015 Elsevier Ltd. All rights reserved.

\section{Introduction}

The structure and property of starch can be altered upon hydrothermal treatment induced in excess water, this phenomenon is well recognised as gelatinisation which is an irreversible order-disorder transition (Jenkins \& Donald, 1998; Ratnayake, Jackson, \& Steve, 2008, chap. 5; Tester \& Debon, 2000). However, it is crucial to distinguish the types of hydrothermal treatments that can be applied to starch because their effects on starch structure depend on their temperature range, water-ratio and duration (Tester \& Debon, 2000; Tester, Debon, \& Karkalas, 1998). The term "heat-moisture treatment" is usually referred to high temperature $\left(90-120^{\circ} \mathrm{C}\right)$ processing and strictly applied at very low moisture content (10-30\%) (Biliaderis, 2009; Tester \& Debon, 2000; Zavareze \& Dias, 2011). Another important phenomenon which may take place in heat-hydrated starch is "annealing." Annealing strongly associates with gelatinisation and affects gelatinisation properties (temperature and enthalpy). It refers to

\footnotetext{
* Corresponding author.

E-mail addresses: silawan.somboonchan@yahoo.com (S. Somboonchan), samuel. lubbers@agrosupdijon.fr (S. Lubbers), gaelle.roudaut@agrosupdijon.fr (G. Roudaut).
}

the application of a temperature treatment below gelatinisation temperature together with a hydration at intermediate up to excess level (40-55\% to >60\%) (Tester \& Debon, 2000). Annealing is associated with partial gelatinisation and leads to an elevation of starch gelatinisation temperature (Tester \& Debon, 2000).

Starch gelatinisation is defined as "the collapse (disruption of molecular order within the starch granule manifested in irreversible changes in properties such as granular swelling) native crystallite melting, loss of birefringence, and starch solubilisation" (Atwell, Hood, Lineback, Varriano-Marston, \& Zobel, 1988). Wheat starch granules begin to swell at $45-50{ }^{\circ} \mathrm{C}$ and continue up to $85^{\circ} \mathrm{C}$, and then lose their birefringence. At $50-55^{\circ} \mathrm{C}$, the enthalpy changes attributed to dissociation of crystalline clusters dramatically decrease, while those attributed to double helices dissociation are observed at $55-60{ }^{\circ} \mathrm{C}$ (Tester \& Morrison, 1990). The gelatinisation temperature is sensitive to the dry matter content of the starch suspensions: the higher the starch content, the higher the gelatinisation temperature (Rolée \& Le Meste, 1999).

Although Atwell's definition (Atwell et al., 1988) limits "pasting" to "the phenomenon following gelatinisation in the dissolution of starch": through granular swelling, amylose leaching and granules disruption, the term "pasting" is usually associated with the general rheological behaviour of starch suspensions upon 
heating. The presence of partially or fully swollen starch granules is a crucial parameter for the rheological behaviour of the paste or resulting since it influences the final texture. The extent of starch swelling is strongly correlated with the leaching of polysaccharides which finally reflects the property of starch paste.

Considering flavour interactions in food, two types have been mainly extensively described in the literature as attractive and repulsive. Attraction is a binding of volatile compounds on a non-volatile substrate while repulsive is a release (Le Thanh, Thibeaudeau, Thibaut, \& Voilley, 1992). There are three physical chemistry approaches to understand flavour interactions in food systems. The first one is the characterisation of flavour molecules partitioning between phases. The second is the analysis of the transport mechanisms where the flavours compounds are carried to food matrices via diffusion or other transport means. The last one is the study of flavour molecule binding to food component (Taylor, 1998).

The structure of starch allows it to have two different types of binding: flavour inclusion complexes and polar interactions (Arvisenet, Le Bail, Voilley, \& Cayot, 2002; Boutboul, Giampaoli, Feigenbaum, \& Ducruet, 2002; Conde-Petit, Escher, \& Nuessli, 2006; Nuessli, Conde-Petit, Trommsdorff, \& Escher, 1995). CondePetit et al. (2006) described flavour binding through two types: non-specific and specific binding. The interactions through sorption are of non-specific type whereas those through starch inclusion complex are specific. Aroma-starch adsorption occurs through hydrogen bonding which is strongly influenced by the polarity of flavour molecules (Boutboul et al., 2002). Viscosity and moisture content of starch matrices are proved to be factors affecting flavour binding and release (Le Thanh et al., 1992).

Various researches have been carried out in order to get a better understanding of starch-flavour interactions. However the experimental conditions vary with each work (type and quantity of starch and flavour, preparation and storage...), it thus remains difficult to have a general rule enabling one to understand the starchflavours interactions as a whole. Among the key factors, the amount of water in the studied systems should also be considered. In the dry state, native starch granules physically adsorb flavour to their porous surface via hydrogen bonding (Escher, Nuessli, \& Conde-Petit, 2000). Flavour retention and release in dry foods depend on the molecular mobility of flavour within the food matrix particularly, when starch is in the glassy state, they are controlled by hydration. The humidity of the system affects flavour release and retention as the latter are directly associated with phase partition (Boutboul et al., 2002) as well as molecular mobility. Boutboul et al. (2002) showed that flavour retention in any types of starch-based matrix increased with increasing flavour polarity. Indeed starch serves as a polar stationary phase and can form hydrogen bonds with those polar flavour molecules. The surface area has been shown to also play a key role (Boutboul et al., 2002; Hau, Gray, \& Taylor, 1998): the higher the specific area, the greater the flavour retention. Moreover granular and native starches are less able to retain flavour since their structure in granular form limits accessibility for flavour (Boutboul et al., 2002).

Certain types of flavour interact via amylose-flavour inclusion complexes in heat-treated starchy matrix with high water content. The formation of flavour-inclusion complex is similar to an amylose-lipid complex, due to the structural similarity of certain flavour molecules with some fatty acids (Jouquand, Ducruet, \& Le Bail, 2006). The inclusion complexes are formed during gelatinisation of starch (Biliaderis, 1992; Jang \& Pyun, 1996) and their melting can be observed by DSC immediately after the onset of thermal events (gelatinisation and melting of starch crystallites).

There are few published works regarding flavour interactions under limiting water or in partially-gelatinised starch as well as on the influence of flavour on starch pasting properties. The existing literature (Blazek, Gilbert, \& Copeland, 2011; Tang \& Copeland, 2007) is in regard of the influence of amylose-lipid complex on pasting properties rather than the influence of flavour. It is still unclear how flavours interact and are retained in partially-gelatinised starch. The present study aimed at understanding interactions between starch and flavour upon moderate hydrothermal treatment and filling in the gap between interactions in native and fully gelatinised starches. Therefore, water content and heating temperature were varied in order to obtain samples at different gelatinisation degrees. Two flavours compounds were chosen according to their abilities to form (ethyl hexanoate) or not (2-hexanone) flavour-inclusion complex for a comparison study. The effects of residual crystallinity and flavours on pasting profile were further investigated.

\section{Materials and methods}

\subsection{Starches and flavours}

Native and starch pregelatinised wheat starch (Pregeflo ${ }^{\circledR}$ W-HV) were kindly provided by Roquette Frères (Lestrem, France). Ethyl hexanoate and 2-hexanone were obtained respectively from Sigma-Aldrich (Steinheim, Germany) and Acros (Geel, Belgium). Methyl heptanoate and ethyl octanoate produced by Sigma-Aldrich (Steinheim, Germany) were used as internal standards of flavour extraction and gas chromatography injection, respectively.

\subsection{Sample preparation}

The samples were prepared with a single flavour in order to compare the effect of flavour addition against no flavour addition separately. Two formulae were chosen according to weight ratios between native wheat starch and water: 20/80 (recipe A) and $50 / 50$ (recipe C) g of starch per $g$ of water. The native starch contained $11 \%$ of moisture content prior its mixing with water. The flavours were added directly onto starch prior to addition of water. The added quantity of ethyl hexanoate was $175 \mathrm{mg} / 100 \mathrm{~g}$ of starch-water mixture while 2-hexanone was $162 \mathrm{mg} / 100 \mathrm{~g}$ of starch-water mixture. Regarding the samples with flavour addition, the added ethyl hexanoate contents per gram of starch at dry basis were $9.6 \mathrm{mg}$ in recipe A and $3.8 \mathrm{mg}$ in recipe C. In case of 2-hexanone, the added contents were $8.9 \mathrm{mg}$ in recipe $\mathrm{A}$, while in recipe $C$ was $3.6 \mathrm{~g}$. The next steps were done in the same manner for samples with/without flavour. Samples were mixed in closed container and left standing on a magnetic stirrer (Variomag Multipoint, Thermo Scientific) at $800 \mathrm{rpm}$ for one hour prior to heating treatment. The mixtures of starch and water were cooked in a double walled-vessel with manual agitation at 65 , and $85^{\circ} \mathrm{C}$ for $10 \mathrm{~min}$. The vessel was equipped with circulating water connected to a temperature controlled bath. Once the samples cooled down to room temperature, they were subjected to Differential Scanning Calorimetry (DSC) and moisture content analysis. The cooked starch samples were kept in closed plastic containers at $-30{ }^{\circ} \mathrm{C}$ prior to the flavour extraction and analysis.

The samples name derived from their formulae and heat treatment temperature, therefore they were denoted as A65, A85, C65 and $\mathrm{C} 85$.

\subsection{Freeze-dried samples}

Cooked starch samples were frozen immediately after their thermal treatment and stored at $-30^{\circ} \mathrm{C}$ before freeze-drying (Triad, Labconco, Kansas City, USA). The freeze-drying process was started from pre-freezing to $-75^{\circ} \mathrm{C}$ for $3 \mathrm{~h}$ then the 
temperature was raised up by $1{ }^{\circ} \mathrm{C} / \mathrm{min}$ to $-30^{\circ} \mathrm{C}$ and left constant there for $14 \mathrm{~h}$. Later the temperature was raised up by $1{ }^{\circ} \mathrm{C} / \mathrm{min}$ to $0{ }^{\circ} \mathrm{C}$ and hold for $36 \mathrm{~h}$. Finally, the temperature was raised up at the same rate to $25^{\circ} \mathrm{C}$. The samples were left at $25^{\circ} \mathrm{C}$ for $40 \mathrm{~h}$ before being taken out of freeze-drier for further experiment. As soon as the samples were taken from freeze-dryer they were manually ground with a mortar. The ground samples were put in an airtight container and stored in the desiccators for further experiments. Moisture contents of starch pastes after freeze-drying ranged from $0.0-1.6 \%$.

\subsection{Differential Scanning Calorimetry study}

Calorimetric measurement was carried out on DSC8000 (Perkin Elmer, Norwalk, CT). The instrument was calibrated with indium. Aluminium hermetic pans and lids were used throughout the study (TA Instruments, Switzerland). Approximately 9-15 mg of fresh sample was put into DSC pan while an empty pan was used as reference. The measurement of each sample was done in triplicate. DSC temperature programming started from $20^{\circ} \mathrm{C}$, rose to $140{ }^{\circ} \mathrm{C}$ at $10^{\circ} \mathrm{C} / \mathrm{min}$ and hold at $140^{\circ} \mathrm{C}$ for $1 \mathrm{~min}$. After that, the system was cooled down at the same rate to initial temperature and hold for $1 \mathrm{~min}$. The second heating was applied in the same conditions in order to differentiate reversible/irreversible phenomena. The flow rate of gas was $20 \mathrm{ml} / \mathrm{min}$. DSC thermograms were analysed with Pyris software for Windows (Version 11.0.0.0449, Perkin Elmer).

To evaluate percentage of residual native starch, the native wheat starch was mixed with water at different ratios according to the formulae, left to equilibrate under agitation for $1 \mathrm{~h}$. After that, they were subjected to DSC analysis. The obtained enthalpies from the first heating scan were standardised per gram of dry starch. The obtained values were represented as energy required for the melting of native starch and expressed in $\mathrm{J} / \mathrm{g}$ of dry weight.

Freshly cooked samples were subjected to DSC and the obtained enthalpies from the first scan were used to calculate the required energy in the same manner as in native starch. Once the samples cooled down, they were subjected to DSC analysis directly to limit syneresis and retrogradation. The percent required energy ratios between freshly cooked to native samples were compared according to their recipes and flavour addition. The obtained percentages were reported as percent relative residual native starch.

\subsection{Flavour analysis}

\subsubsection{Simultaneous distillation extraction}

Five grams (wet weight) of paste samples were used per extraction and each sample was extracted in triplicate. Paste samples were put into $250 \mathrm{ml}$ round bottom flask together with $10 \mathrm{~g}$ of sodium chloride and $100 \mathrm{ml}$ of distilled water. Before the extraction, $2 \mu \mathrm{l}$ of methyl heptanoate were added to the sample as internal standard of extraction. In order to avoid bubbling during extraction, approximately $1 \mathrm{ml}$ of antifoam (Antifoam 204, Sigma-Aldrich; Steinheim, Germany) and glass beads were added into the sample flask. The sample flask was then installed onto Likens-Nickerson apparatus. $25 \mathrm{ml}$ of dichloromethane (SigmaAldrich; Steinheim, Germany) were used as an extraction solvent. Approximately $10 \mathrm{ml}$ of dichloromethane were added into the Likens-Nickerson apparatus while the remaining was added into $50 \mathrm{ml}$ round bottom flask prior extraction. The sample flask was heated up to $185^{\circ} \mathrm{C}$ while the solvent flask was heated at $70{ }^{\circ} \mathrm{C}$ and they were left to undergo extraction for $45 \mathrm{~min}$. Once the extraction was finished, dichloromethane phases were collected and reconstituted to $25 \mathrm{ml}$. $2 \mu \mathrm{l}$ of ethyl octanoate were added to the reconstituted sample prior to injection into GC. Flavour quantification was done by comparing with standard injection.

\subsubsection{Gas chromatography}

Gas chromatography (GC) was performed on Hewlett Packard 6890 - G1530A series Chromatography, which was equipped with flame ionisation detector (FID). The samples were introduced automatically by autosampler (G1512AX) and injector HO6890 series. Volatile flavour compounds were separated on a silica capillary column (30 $\mathrm{m} \times 0.32 \mathrm{~mm}$ i.d.) coated with carbowax $20 \mathrm{M}$ as stationary phase with a film thickness of $0.50 \mu \mathrm{m}$ (DB-Wax; Agilent J\&W Scientific, Folsom, CA). The carrier gas used was ultra-high purity helium with constant flow rate of $1.5 \mathrm{ml} / \mathrm{min}$ and pressure of $7 \mathrm{psi}$. The split ratio of 25:1 was applied. FID make up gas flow was $15 \mathrm{ml} / \mathrm{min} . \mathrm{H}_{2}$ flow was $30 \mathrm{ml} / \mathrm{min}$ and airflow was $300 \mathrm{ml} / \mathrm{min}$. FID and injection temperature was $240^{\circ} \mathrm{C}$. GC temperature programming was started at $40^{\circ} \mathrm{C}$, further increased by $5^{\circ} \mathrm{C}$ per min to $100{ }^{\circ} \mathrm{C}$, finally increased $10^{\circ} \mathrm{C}$ per min to $220^{\circ} \mathrm{C}$. Total run time was $22 \mathrm{~min}$. Data acquisition and analyses were performed with Star Chromatography Work Station Version 5.50 (Varian).

\subsection{Starch pasting profile}

The gelatinised samples were freeze-dried prior to analysis with RVA since rapid freezing and subsequent freeze drying in appropriate conditions prevented retrogradation by keeping the product in sub-Tg conditions (Roos, 2010). Starch pasting profiles were analysed by Rapid Visco ${ }^{\mathrm{TM}}$ Analyser: RVA ${ }^{\mathrm{TM}}$ Super 4 (Newport Scientific Warriewood, Australia). The instrument was calibrated with standard flour provided by instrument manufacturer $(3.5 \mathrm{~g}$ per $25 \mathrm{ml}$ of deionised water). $3 \mathrm{~g}$ of sample (native, pregelatinised and freeze-dried) were used and the water content adjusted to a final value of $90 \%$ hydration. Each starch sample was mixed with $25 \mathrm{ml}$ of deionised water in canister and equally shaken prior to be placed into the instrument. RVA was programmed to agitate the sample at $960 \mathrm{rpm}$ for $10 \mathrm{~s}$, then at $160 \mathrm{rpm}$ where the agitation was kept constant. Starch suspension was initially heated at $50{ }^{\circ} \mathrm{C}$ and raised to $95^{\circ} \mathrm{C}$ in $3 \mathrm{~min}$ and $42 \mathrm{~s}$. The temperature was then maintained at $95^{\circ} \mathrm{C}$ for $2.5 \mathrm{~min}$ before cooling to $50^{\circ} \mathrm{C}$ over $3 \mathrm{~min}$ and $48 \mathrm{~s}$. The values of peak viscosity, trough (minimum viscosity), and final viscosity were recorded. The values of breakdown (derived from the difference between peak viscosity and minimum viscosity) and set back (derived from the difference between final viscosity and minimum viscosity) were calculated automatically by Thermocline software (Thermocline for Windows ${ }^{\circledR}$, Version 2.2, Newport Scientific, Warriewood, Australia). All analyses were done in triplicate.

\subsection{Statistical analysis}

All statistical analysis conducted by XLSTAT ${ }^{\mathrm{TM}}$ software for Windows ${ }^{\circledR}$ Version 2013.1.02 (Addinsoft Inc, France). ANOVA was used to determine significant difference among group and effect of recipe and flavour addition.

\section{Results and discussion}

\subsection{Flavour residual content upon hydrothermal treatment}

Sample pastes were subjected to Likens-Nickerson extraction. The extracted amount of flavour compound ranged from 0.38 to $1.12 \mathrm{mg} / \mathrm{g}$ starch (dry basis) and from 0.23 to $1.28 \mathrm{mg} / \mathrm{g}$ starch (dry basis) for ethyl hexanoate and 2-hexanone, respectively. The flavour residual content in the starchy matrices was reported as percent ratio to initial concentration (Fig. 1). The overall results suggested that water content influenced flavour residual content. In excess of water (recipe A), cooking at $65^{\circ} \mathrm{C}$ induced significantly less flavour loss compared to cooking at $85^{\circ} \mathrm{C}$. The higher flavour 


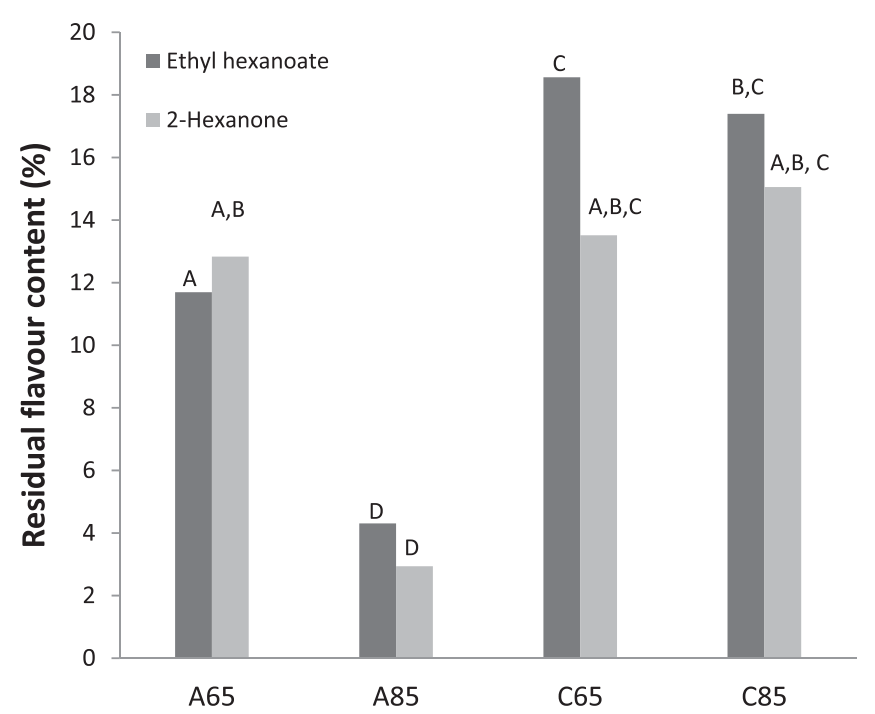

Fig. 1. Residual flavour content after cooking (\% of initial content). Different labels in capital letters $(A-D)$ indicate significant difference $(P<0.001)$ at $95 \%$ confidence interval by Fisher LSD test.

loss in A85 might be due to the couple hydration and temperature favouring the mass transfer compared to the other conditions.

Since there was no difference in gelatinisation extent (Table 1 ), the different flavour residual content (for both types of flavours) in samples A did not result from a structural difference but solely from the extent of the thermal treatment. In case of recipes $C$, there is no significant difference in flavour residual content between either flavour type or thermal treatment applied. Comparing recipe A with recipe $C$, it can be noted that gelatinisation at high water content favoured residual flavour content for the $65^{\circ} \mathrm{C}$ treated samples, whereas no difference existed when the samples were both treated at $85^{\circ} \mathrm{C}$. This suggests that the complete gelatinisation achieved at $65{ }^{\circ} \mathrm{C}$ and high hydration permitted greater

Table 1

DSC enthalpy and residual native starch.

\begin{tabular}{llll}
\hline Sample recipe & Cooking temp. $\left({ }^{\circ} \mathrm{C}\right)$ & $\begin{array}{l}\text { Enthalpy } \\
(\mathrm{J} / \mathrm{g})\end{array}$ & $\begin{array}{l}\text { \% Residual native } \\
\text { starch }^{*}\end{array}$ \\
\hline A & NA & $9.4^{\mathrm{A}}$ & $\mathrm{NA}$ \\
A + ethyl hexanoate & & $9.6^{\mathrm{A}}$ & $\mathrm{NA}$ \\
A + 2-hexanone & & $4.5^{\mathrm{C}}$ & $\mathrm{NA}$ \\
C & NA & $9.0^{\mathrm{A}, \mathrm{B}}$ & $\mathrm{NA}$ \\
C + ethyl hexanoate & & $7.9^{\mathrm{B}}$ & $\mathrm{NA}$ \\
C + 2-hexanone & & $9.4^{\mathrm{A}}$ & $\mathrm{NA}$ \\
A & 65 & $0.3^{\mathrm{D}}$ & $2.9^{\mathrm{a}}$ \\
A + ethyl hexanoate & & $0.3^{\mathrm{D}}$ & $3.3^{\mathrm{a}}$ \\
A + 2-hexanone & & $0.4^{\mathrm{D}}$ & $8.5^{\mathrm{a}}$ \\
A & 85 & $0.0^{\mathrm{D}}$ & $0.0^{\mathrm{b}}$ \\
A + ethyl hexanoate & & $0.0^{\mathrm{D}}$ & $0.0^{\mathrm{b}}$ \\
A + 2-hexanone & & $0.0^{\mathrm{D}}$ & $0.0^{\mathrm{b}}$ \\
C & 65 & $3.2^{\mathrm{E}}$ & $36.0^{\mathrm{C}}$ \\
C + ethyl hexanoate & & $3.2^{\mathrm{E}}$ & $40.5^{\mathrm{C}}$ \\
C + 2-hexanone & & $3.4^{\mathrm{E}}$ & $36.2^{\mathrm{C}}$ \\
C & 85 & $2.3^{\mathrm{F}}$ & $25.8^{\mathrm{d}}$ \\
C + ethyl hexanoate & & $1.0^{\mathrm{F}}$ & $12.8^{\mathrm{d}}$ \\
C + 2-hexanone & & $2.1^{\mathrm{F}}$ & $22.1^{\mathrm{d}}$ \\
\hline
\end{tabular}

NA: Not applicable.

Percentage ratio of melting enthalpies of cooked sample versus native starch of each recipe and flavour addition. Significance tests were performed on each parameter (enthalpies and percent residual of native) separately. Different labels $(A-F, a-d)$ indicate significant difference $(P<0.001)$ at $95 \%$ confidence interval by Fisher's LSD test. starch-flavour interactions and retention than in the less gelatinised, more crystalline and thus less accessible starch treated at lower hydration. On the opposite, high temperature treatment contributed to a more important flavour loss possibly caused by a greater evaporation in the open system.

\subsection{Gelatinisation properties of native wheat starch with and without flavour addition}

Fig. 2 shows the melting thermograms of native wheat starch at two different starch-water ratios with and without aroma compound. A single endotherm with trailing was found for all starch-water ratios and flavour additions. Cooking starch at limiting water has been described to exhibit a multiphase endotherm (Baks, Ngene, van Soest, Janssen, \& Boom, 2007; Biliaderis, 1992; Jang \& Pyun, 1996; Jouquand et al., 2006; Rolée \& Le Meste, 1999). However, the water threshold to observe two separate endotherms for wheat starch has been described to be below $55 \%$ moisture content, which was the lowest water content $55.5 \%$ for C samples) (Rolée \& Le Meste, 1999) which probably explained the trailing shape rather than a clear double endotherm.

There is no significant difference on gelatinisation temperature of native wheat starch with or without flavour. The average onset, peak and conclusion temperatures from each native sample were 52.9, 57.9 and 62.7, respectively. There is no significant effect of either water ratio or flavour content. The obtained values were similar to those from previous research except for the conclusion temperature that is lower (Ratnayake et al., 2008, chap. 5; Rolée \& Meste, 1997; Tester et al., 1998). There are several possibilities to explain this difference: wheat cultivar, granule size, moisture content, study conditions, granule size, amylose and amylopectin contents (Tester et al., 1998; Vermeylen, Goderis, Reynaers, \& Delcour, 2005).

Enthalpies of native wheat starch and cooked starch are shown in Table 1. According to literature data, enthalpy of native wheat starch may range from 9 to $18 \mathrm{~J} / \mathrm{g}$ (Baks et al., 2007; Jenkins \& Donald, 1998; Ratnayake et al., 2008, chap. 5; Rolée \& Meste, 1997; Tester et al., 1998). Those studies measured gelatinisation enthalpy for wheat starch only without flavour addition at various moisture contents.

In the present work, the enthalpies obtained for native wheat starch ranged from 4.5 to $10.4 \mathrm{~J} / \mathrm{g}$. It is noteworthy that gelatinisation enthalpies of native starch at the highest hydration level (A) were significantly reduced in presence of 2-hexanone whereas the enthalpies for recipe $C$ remained similar to literature data with or without flavour as 2-hexanone has a much higher aqueous solubility $(16.2 \mathrm{~g} / \mathrm{L})$ at $25^{\circ} \mathrm{C}$ than ethyl hexanoate are $(0.65 \mathrm{~g} / \mathrm{L})$, (CovarrubiasCervantes, Bongard, Champion, \& Voilley, 2005a). The studied samples contained 2.0 and $3.2 \mathrm{~g}$ of 2-hexanone per litre of water for recipe $A$ and $C$, respectively. In other words, the used concentrations of 2-hexanone were below solubility limit whereas they were above the limit for ethyl hexanoate. The property of water that acting as solvent in the system might be altered due to dissolved flavour compounds. As a consequence this difference in solvent water could affect the gelatinisation enthalpy. Finally, the substrate concentration, through the availability of water, could also be another possible reason for the lower enthalpy of recipe A sample in presence of 2-hexanone. Indeed the solubility of flavour compounds in carbohydrate solutions has been suggested to decrease when the substrate concentration increased (Covarrubias-Cervantes, Bongard, Champion, \& Voilley, 2005b; Covarrubias-Cervantes et al., 2005a). Starch concentration was higher in recipe $C$ than in $A$, it could lower the solubility of 2-hexanone which would then lead to the same effect. Moreover, Covarrubias-Cervantes et al. (2005b) exhibited aroma solubility in water decreased when aroma hydrophobicity increased and in this case, ethyl hexanoate $(\log P=2.80$ (Savary, 


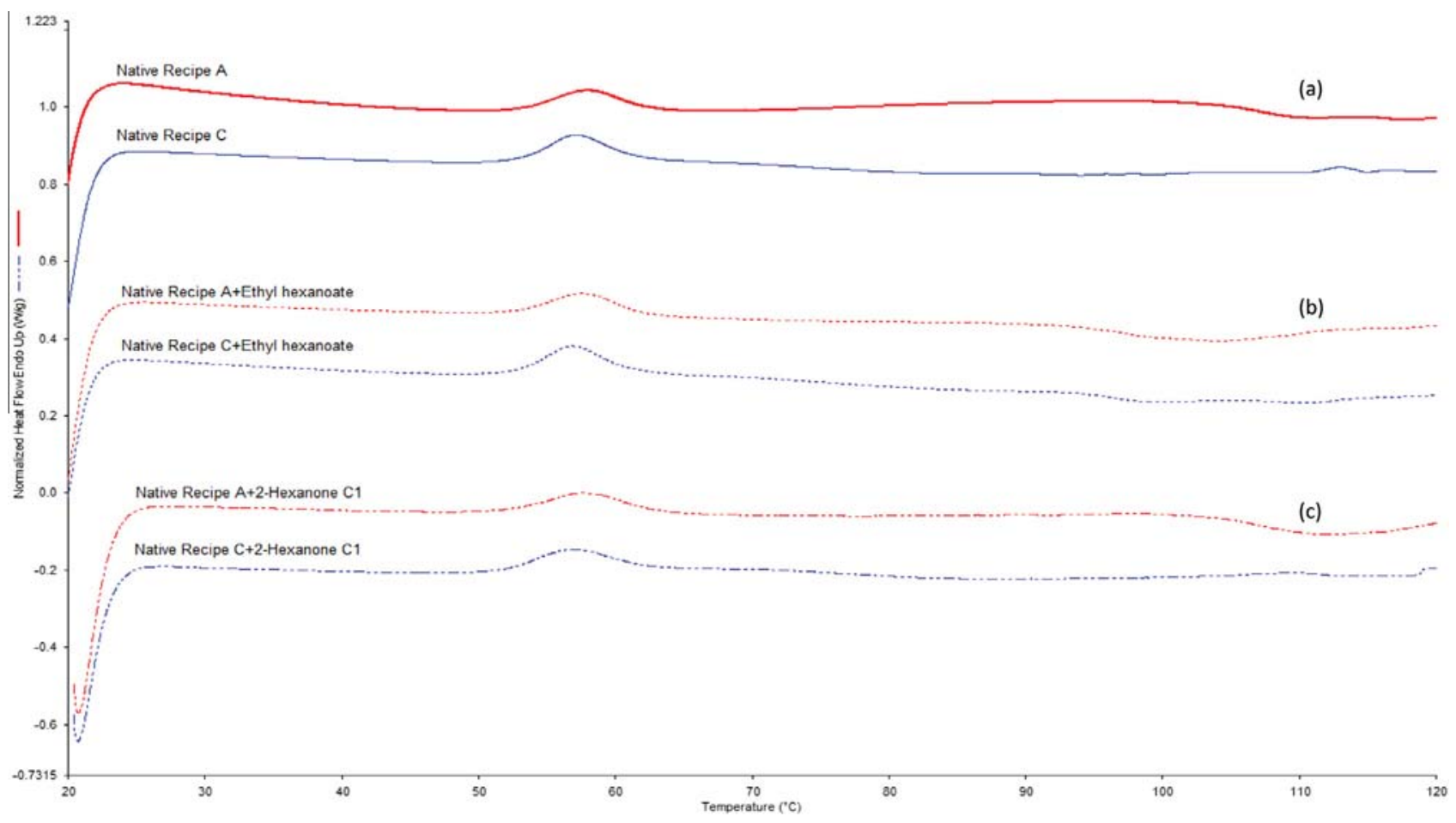

Fig. 2. DSC thermograms of first heating scan of native wheat starch at 80/20 (A) and 50/50 (C) water/starch wet weight ratio without aroma compounds (a), with ethyl hexanoate (b), and with 2-hexanone (c).

Lafarge, Doublier, \& Cayot, 2007)) exhibits a higher hydrophobicity than 2-hexanone $(\log P=1.38$ (Jouquand, Ducruet, \& Giampaoli, 2004)).

Nuessli, Sigg, Conde-Petit, and Escher (1997) found that decanal was unable to form a complex with starch but on the contrary gave exothermic phase transition upon heating. Hence, lowering of enthalpy of recipe $A$ in the presence of 2-hexanone to $4.5 \mathrm{~J} / \mathrm{g}$ might be due to compensation between exothermic and endothermic events. In the study of Nuessli et al. (1997), thermal analysis was done on cooked sample while this study was done with native starch, the exothermic event possibly occurred at lower temperature in their work. Fig. 2(c) shows that there is an exothermic event starting at $\sim 105^{\circ} \mathrm{C}$. Considering recipes $\mathrm{A}$ and $\mathrm{C}$, it was found that this event was more clearly exothermic for recipe $A$ than $C$. These exothermic phase transitions were greater with 2-hexanone in both recipes but were broader and wider in A than in $C$ samples. These exothermic events disappeared between the first and second DSC heating in agrees with Nuessli et al. (1997). These assumptions require more study of the involved flavour-starch interaction to explain this exothermic behaviour.

\subsection{Sample properties after hydrothermal treatment}

Although the samples were prepared in an open system, their final water content around $82 \%$ confirmed that there were no dramatic loss of water upon preparation ( $<10 \%$ of the initial water content).

Fig. 3 shows DSC thermograms of the first scan of freshly prepared samples. All heat-treated samples from recipe A no longer exhibited any endothermic event, suggesting that A samples with or without flavour were fully gelatinised. In comparison to native starch, it was found that the maximum of the gelatinisation endotherm of the $\mathrm{C}$ samples shifted from $53^{\circ} \mathrm{C}$ (for native starch) to $68-76^{\circ} \mathrm{C}$. This could result from an annealing effect (Tester \& Debon, 2000; Zavareze \& Dias, 2011) resulting from the treatment conditions. The enthalpies of the endotherms were measured, and their ratio to the gelatinisation enthalpy of native equivalent calculated (as percent of residual native starch) and reported in Table 1. Comparing percent residual native starch content, between recipes A and C, it can clearly be seen that contrary to samples A, samples C were only partially gelatinised during the hydrothermal process at both $65^{\circ} \mathrm{C}$ and $85^{\circ} \mathrm{C}$. This emphasised that the higher the hydration, the greater the gelatinisation extent. The treatment temperature did not significantly influence gelatinisation when water was in excess. On the opposite, recipe $C$ exhibited a higher percent of residual native starch suggesting that in these conditions, the hydration (final value equal to $55.5 \% \mathrm{wb}$ ) was limiting the gelatinisation extent. In this case, the temperature strongly influenced the gelatinisation extent: C65 and C85 exhibited respectively 38\% and $25 \%$ residual native starch. This suggested that the higher temperature compensated for the low hydration. There was no effect of flavour addition on the extent of gelatinisation of any sample. The endotherm observed at $95-110^{\circ} \mathrm{C}$, which could represent the melting of starch-flavour inclusion complex was not clearly observed for all flavour containing samples. However, flavour analysis results confirmed the presence of flavour in studied samples (Fig. 1).

\subsection{Pasting profile}

The prepared samples were freeze-dried and analysed by RVA and compared with commercial native and pregelatinised starches. Table 2 represents RVA pasting properties of each sample. The data (peak viscosity, trough, breakdown, final viscosity, setback, pasting time and pasting temperature) together with sample formulae, treatment temperature and types of flavour were subjected to an ANOVA. Native and pregelatinised samples exhibited different pasting behaviour, actually representing extreme pasting profiles. Indeed, native starch showed the highest peak, trough, breakdown viscosities, and on the opposite, pregelatinised starch exhibited the 


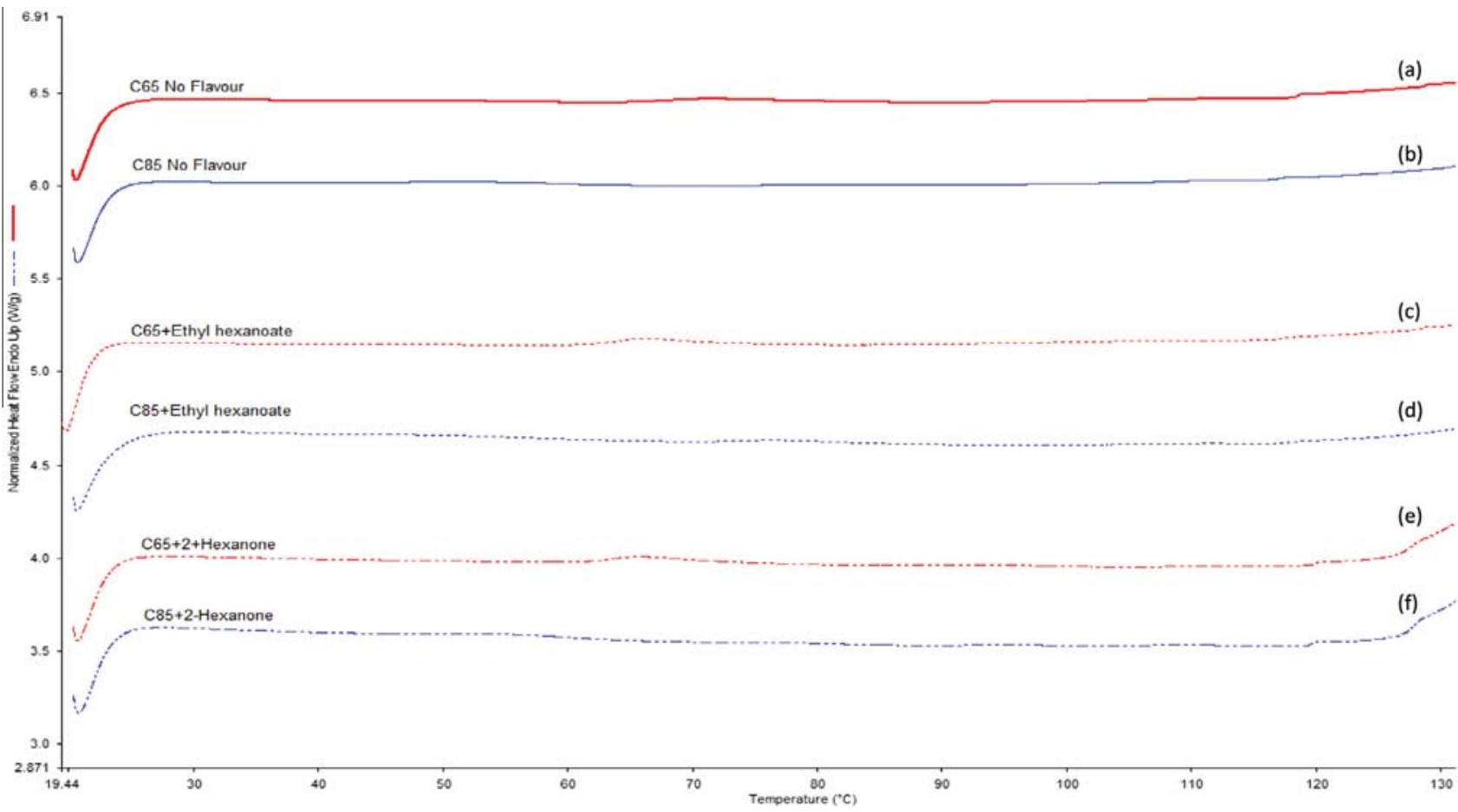

Fig. 3. DSC thermograms of first scan of freshly cooked samples (starch paste) from recipe C; C65 No Flavour (a), C85 No Flavour4 (b), C65 with ethyl hexanoate (c), C85 with ethyl hexanoate (d), C65 with 2-hexanone (e) and C85 with 2-hexanone (f).

Table 2

RVA pasting properties in comparison between sample treatment (recipe, cooking temperature and flavour addition).

\begin{tabular}{|c|c|c|c|c|c|c|}
\hline \multirow[t]{2}{*}{ Sample } & \multirow[t]{2}{*}{ Flavour addition } & \multicolumn{4}{|c|}{ Viscosity $(\mathrm{cP})$} & \multirow{2}{*}{$\begin{array}{l}\text { Pasting temp. } \\
\left({ }^{\circ} \mathrm{C}\right)\end{array}$} \\
\hline & & Peak & Trough & Breakdown & Final & \\
\hline Native & No flavour & 6806 & 4583 & 2222 & 8480 & 66 \\
\hline Pre-Gel & No flavour & 227 & 116 & 111 & 286 & 60 \\
\hline A65 & $\begin{array}{l}\text { No flavour } \\
\text { 2-Hexanone } \\
\text { Ethyl hexanoate }\end{array}$ & $\begin{array}{l}2686^{\mathrm{E}} \\
2723^{\mathrm{E}} \\
3118^{\mathrm{D}}\end{array}$ & $\begin{array}{l}2329^{\mathrm{D}} \\
2441^{\mathrm{D}} \\
2629^{\mathrm{B}, \mathrm{C}, \mathrm{D}}\end{array}$ & $\begin{array}{l}357^{\mathrm{E}} \\
282^{\mathrm{E}, \mathrm{F}} \\
489^{\mathrm{D}}\end{array}$ & $\begin{array}{l}6304^{\mathrm{D}} \\
5478^{\mathrm{F}} \\
7456^{\mathrm{C}}\end{array}$ & $\begin{array}{l}83^{\mathrm{A}, \mathrm{B}} \\
75^{\mathrm{C}} \\
80^{\mathrm{A}, \mathrm{B}, \mathrm{C}}\end{array}$ \\
\hline A85 & $\begin{array}{l}\text { No flavour } \\
\text { 2-Hexanone } \\
\text { Ethyl hexanoate }\end{array}$ & $\begin{array}{l}4048^{\mathrm{B}} \\
3470^{\mathrm{C}} \\
4529^{\mathrm{A}}\end{array}$ & $\begin{array}{l}3213^{\mathrm{A}} \\
2736^{\mathrm{B}, \mathrm{C}} \\
3185^{\mathrm{A}}\end{array}$ & $\begin{array}{l}835^{\mathrm{B}} \\
733^{\mathrm{B}} \\
1344^{\mathrm{A}}\end{array}$ & $\begin{array}{l}7960^{B} \\
7276^{C} \\
10183^{A}\end{array}$ & $\begin{array}{l}75^{\mathrm{C}} \\
78^{\mathrm{B}, \mathrm{C}} \\
60^{\mathrm{D}}\end{array}$ \\
\hline C65 & $\begin{array}{l}\text { No flavour } \\
\text { 2-Hexanone } \\
\text { Ethyl hexanoate }\end{array}$ & $\begin{array}{l}2740^{\mathrm{E}} \\
2794^{\mathrm{E}} \\
3407^{\mathrm{C}}\end{array}$ & $\begin{array}{l}2534^{\mathrm{C,D}} \\
2594^{\mathrm{C}, \mathrm{D}} \\
2815^{\mathrm{B}}\end{array}$ & $\begin{array}{l}206^{\mathrm{F}, \mathrm{G}} \\
201^{\mathrm{F}, \mathrm{G}} \\
592^{\mathrm{C}}\end{array}$ & $\begin{array}{l}5730^{\mathrm{D}, \mathrm{E}} \\
5685^{\mathrm{E}, \mathrm{F}} \\
7605^{\mathrm{B}, \mathrm{C}}\end{array}$ & $\begin{array}{l}82^{\mathrm{A}, \mathrm{B}} \\
84^{\mathrm{A}, \mathrm{B}} \\
83^{\mathrm{A}, \mathrm{B}}\end{array}$ \\
\hline C85 & $\begin{array}{l}\text { No Flavour } \\
\text { 2-Hexanone } \\
\text { Ethyl hexanoate }\end{array}$ & $\begin{array}{l}1762^{\mathrm{G}} \\
1763^{\mathrm{G}} \\
2259^{\mathrm{F}}\end{array}$ & $\begin{array}{l}1584^{\mathrm{F}} \\
1543^{\mathrm{F}} \\
2125^{\mathrm{E}}\end{array}$ & $\begin{array}{l}178^{\mathrm{E}, \mathrm{F}, \mathrm{G}} \\
220^{\mathrm{E}, \mathrm{F}, \mathrm{G}} \\
135^{\mathrm{G}}\end{array}$ & $\begin{array}{l}3819^{\mathrm{G}} \\
3550^{\mathrm{H}} \\
5719^{\mathrm{E}, \mathrm{F}}\end{array}$ & $\begin{array}{l}85^{\mathrm{A}} \\
87^{\mathrm{A}} \\
85^{\mathrm{A}}\end{array}$ \\
\hline
\end{tabular}

Different labels in capital letters (A-G) indicate significant difference among each RVA parameter according to interaction between recipe, cooking temperature and flavour addition. The significant tests were analysed at $95 \%$ confidence interval by Fisher LSD test.

lowest viscosity values. The very low final viscosity of the pregelatinised starch suggested that it was unable to form a gel, pointing to the severity of industrial treatment which may have not only gelatinised the sample but possibly also partially hydrolysed some macromolecules preventing them from retrograding upon cooling. The viscosities of $A 85$ were the highest among prepared samples; for A65 and C65 they were comparable and higher than for C85. In the literature, peak viscosity is attributed to amylopectin content, crystallinity and swelling (Lan et al., 2008), breakdown is related to intragranular bonds breakage and granule stability (Zavareze \& Dias, 2011) and final viscosity to reorganisation ability.

Pasting temperatures of heat-treated samples with/without flavour were higher than for both native and commercial pregelatinised starch. Pasting temperatures of sample with flavour were higher than both native and pregelatinised starch. Such an increase of pasting temperature upon thermal treatment has been associated with the formation of a more organised structure (Tester et al., 1998) below gelatinisation through annealing or heat moisture treatments (Biliaderis, 2009; Zavareze \& Dias, 2011). The effects of these two treatments are controversial depending on the starches studied or the authors: in some cases, annealing increased peak viscosity (Jacobs, Eerlingen, \& Delcour, 1996; Zavareze \& Dias, 2011).

Sample A85 showed a high peak viscosity which could result from an incomplete swelling during the initial heating treatment in spite of a complete crystal melting (no residual crystallinity). This is aligned with phenomenological aspects of gelatinisation in which melting endotherm in DSC is shown to occur at $55-65{ }^{\circ} \mathrm{C}$ 


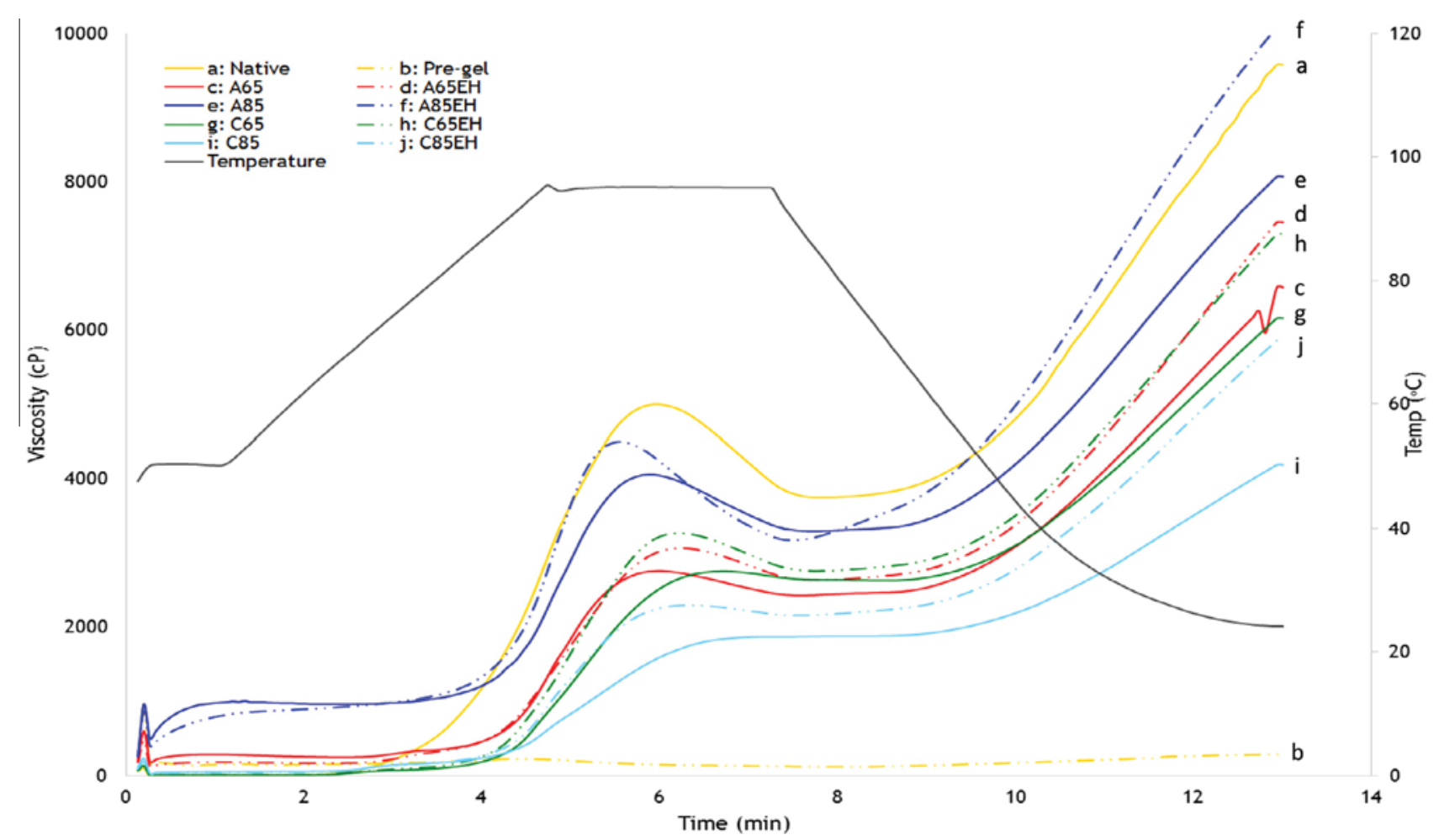

Fig. 4. RVA pasting profiles of freeze-dried starch in comparison between without flavour and with ethyl hexanoate (EH): Native (a), Pre-gel (b), A65 (c), A65EH (d), A85 (e), A85EH (f), C65 (g), C65EH (h) and C85 (i), C85EH (j).

while swelling can continue to develop up to $100{ }^{\circ} \mathrm{C}$ (Eliasson \& Larsson, 1993). In the A samples, whether heated at 85 or $65^{\circ} \mathrm{C}$, the crystals were melted but the granules not fully swollen during their preparation treatment, thus they could swell during the RVA analysis. In A65, the peak viscosity is lower than in $\mathrm{A} 85$, as if the granules had a lower swelling capacity such as the one caused by annealing treatment (Zavareze \& Dias, 2011). Annealing has been described (Tester et al., 1998) as reorganising the granular structure towards an increased granular stability which could cause the observed lower peak and breakdown viscosities of A65. C85 sample had the highest residual crystalline starch content (Table 1) but showed the lowest viscosities possibly as a result of limited swelling from reinforced granule structure.

In the temperature and hydration ranges of the samples preparation, the water contents used in samples preparation could be considered in the range of gelatinisation (in terms of crystal melting) but they were also close to the boundary of annealing and heat-moisture treatment as defined by Biliaderis (2009) as previously seen through the lower swelling in the prepared samples. Indeed peak viscosity values were always lower than for native starch due to lower crystallinity and lower ability to swell, however they were higher than pregelatinised starch values.

Heat-moisture treatment (below gelatinisation stage) disrupts the crystalline structure and dissociates the double helical structure in the amorphous region, followed by the arrangement of the disrupted crystals (Gunaratne \& Hoover, 2002; Zavareze \& Dias, 2011). Wheat starches that underwent heat-moisture and annealing treatments were found to exhibit a reduced swelling power (Zavareze \& Dias, 2011). However, the two hydrothermal treatments had opposite effect on pasting profiles. Wheat starch was found to exhibit increasing pasting temperature but decreasing peak viscosity, final viscosity and breakdown after heat-moisture treatment (Sun, Dai, Nan, \& Xiong, 2014; Tester \& Debon, 2000; Zavareze \& Dias, 2011). This is in agreement with the occurrences found in recipe $C$ samples.
The statistical analysis of RVA results versus flavour addition effect found that ethyl hexanoate containing samples had significantly higher viscosities than both the no flavour added ones and 2-hexanone containing ones which exhibited comparable pasting profile parameters (Table 2 and Fig. 4). This suggests that the type of interactions set between 2-hexanone and starch did not significantly affect the starch pasting behaviour similarly to the results obtained by Blazek et al. (2011) with non complexing fatty acids and starch. Although, no flavour-starch complex were detected in the prepared samples, it is likely that the structure (such as complex but not exclusively) formed by the interaction between starch and ethyl hexanoate affected the starch pasting profile. Blazek et al. (2011) suggested that complexing agents could promote the formation of single amylose helices over double helical structures, causing amylose to form globular aggregates rather than networks such as those observed in pastes with no added lipid or in the presence of non-complexing lipids. Tang and Copeland (2007) concluded that the inclusion of lipids in starch pastes decreased the holding viscosity, whereas the final viscosity was increased. In the present study, all pasting parameters were found to increase with the addition of ethyl hexanoate. If the interactions were comparable, this discrepancy could possibly be due to experimental conditions: sample preparation, type and concentration of complexing agents. Further work on the fine structure of the samples is currently ongoing to get a clear understanding of these results.

At limiting water, starch was still able to complete the gelatinisation defined as structure disruption due to temperature compensation. Indeed continuous heating allowed crystallites to undergo a conventional melting transition. Although there were insufficient water (compared to the usual excess hydration), the thermal energy was sufficient to both break the inter-mesogen hydrogen bonds and increase the mobility of the amylopectin double helices side-by-side (Waigh, Gidley, Komanshek, \& Donald, 2000). However low water content limited granule swelling capacity and in the most extreme conditions, crystalline disruption. 
Although the flavour-inclusion complex could not be detected, there could be still be some, or flavour could either be trapped between amylose helix (Biais, Le Bail, Robert, Pontoire, \& Buléon, 2006).

\section{Conclusion}

Varying the hydrothermal treatment conditions yielded to starch matrices with different starch properties with regards to structure, flavour residual content and pasting properties. The studied conditions did not particularly lead to the detection of flavour-inclusion complex but both flavours were able to interact somehow with the starch and were retained in the starch. Residual ethyl hexanoate contents were similar to 2-hexanone for every recipe. The lowest residual flavour content $(\sim 4 \%)$ was found in the samples treated at both high moisture and high temperature (A85). This emphasised the thermal effect at high level of hydration. Indeed, A preparations had a greater mobile phase than $\mathrm{C}$ ones, and at $85^{\circ} \mathrm{C}$, the water had higher mobility than at $65^{\circ} \mathrm{C}$ which could facilitate flavour evaporation. The studied conditions promoted full gelatinisation at the highest moisture content (A65 and A85) and partial gelatinisation at the lowest moisture content (C65 and C85), however they all led to incomplete swelling. At the lowest temperature or at the lowest hydration level, the pasting profiles reflected the effects of both gelatinisation and annealing phenomena. This emphasises that flavour compounds were able to interact with starch even only partially gelatinised and with incompletely swollen granules. The type of interaction between the polysaccharide and both flavour compounds remain unclear and further investigation is needed to understand the retention of these flavour compounds since they both are known to interact with starch differently.

A structural study is required to further understand the effect of hydrothermal treatment in the presence of flavour.

\section{Acknowledgements}

S. Somboonchan is grateful to the French Embassy in Thailand and Qi Statistics Ltd. for financial support. Authors thank Roquette Frères for supplying the starches.

\section{References}

Arvisenet, G., Le Bail, P., Voilley, A., \& Cayot, N. (2002). Influence of physicochemical interactions between amylose and aroma compounds on the retention of aroma in food-like matrices. Journal of Agricultural and Food Chemistry, 50(24), 7088-7093.

Atwell, W. A., Hood, L. F., Lineback, D. R., Varriano-Marston, E. \& Zobel, H. F. (1988) The terminology and methodology associated with basic starch phenomena. Cereal Food World, 33(3), 306-311.

Baks, T., Ngene, I. S., van Soest, J. J. G., Janssen, A. E. M., \& Boom, R. M. (2007). Comparison of methods to determine the degree of gelatinisation for both high and low starch concentrations. Carbohydrate Polymers, 67(4), 481-490.

Biais, B., Le Bail, P., Robert, P., Pontoire, B., \& Buléon, A. (2006). Structural and stoichiometric studies of complexes between aroma compounds and amylose. Polymorphic transitions and quantification in amorphous and crystalline areas. Carbohydrate Polymers, 66(3), 306-315.

Biliaderis, C. G. (1992). Structures and phase transitions of starch in food systems. Food Technology, 46, 98-109.

Biliaderis, C. G. (2009). Structural transitions and related physical properties of starch. In J. BeMiller \& R. Whistler (Eds.), Starch: Chemistry and technology (3rd ed., pp. 293-372). New York: Academic Press.

Blazek, J., Gilbert, E. P., \& Copeland, L. (2011). Effects of monoglycerides on pasting properties of wheat starch after repeated heating and cooling. Journal of Cereal Science, 54(1), 151-159.

Boutboul, A., Giampaoli, P., Feigenbaum, A., \& Ducruet, V. (2002). Influence of the nature and treatment of starch on aroma retention. Carbohydrate Polymers, 47(1), 73-82.
Conde-Petit, B. a., Escher, F., \& Nuessli, J. (2006). Structural features of starch-flavor complexation in food model systems. Trends in Food Science and Technology, 17(5), 227-235.

Covarrubias-Cervantes, M., Bongard, S., Champion, D., \& Voilley, A. (2005a). Effects of the nature and concentration of substrates in aqueous solutions on the solubility of aroma compounds. Flavour and Fragrance Journal, 20(3), 265-273.

Covarrubias-Cervantes, M., Bongard, S., Champion, D., \& Voilley, A. (2005b) Temperature effect on solubility of aroma compounds in various aqueous solutions. Lebensmittel-Wissenschaft und-Technologie, 38, 371-378.

Eliasson, A. C., \& Larsson, K. (1993). Cereal in breadmaking: A molecular colloid approach. New York: Marcel Dekker.

Escher, F. E., Nuessli, J., \& Conde-Petit, B. (2000). Interaction of flavour compounds with starch in food processing. In D. D. Roberts \& A. J. Taylor (Eds.), Flavour release (pp. 230-245). Washington DC: American Chemical Society Symposium Series 763.

Gunaratne, A \& Hoover, R (2002). Effect of heat-moisture treatment on the structure and physicochemical properties of tuber and root starches. Carbohydrate Polymers, 49(4), 425-437.

Hau, M. Y. M., Gray, D. A., \& Taylor, A. J. (1998). Binding of volatiles to extruded starch at low water contents. Flavour and Fragrance Journal, 13(2), 77-84.

Jacobs, H., Eerlingen, R. C., \& Delcour, J. A. (1996). Factors affecting the viscoamylograph and rapid visco-analyzer evaluation of the impact of annealing on starch pasting properties. Starch - Stärke, 48(7-8), 266-270.

Jang, J. K., \& Pyun, Y. R. (1996). Effect of moisture content on the melting of wheat starch. Starch - Stärke, 48(2), 48-51.

Jenkins, P. J., \& Donald, A. M. (1998). Gelatinisation of starch: A combined SAXS/ WAXS/DSC and SANS study. Carbohydrate Research, 308(15), 133-147.

Jouquand, C., Ducruet, V., \& Le Bail, P. (2006). Formation of amylose complexes with C6-aroma compounds in starch dispersions and its impact on retention. Food Chemistry, 96(3), 461-470.

Jouquand, C. 1., Ducruet, V., \& Giampaoli, P. (2004). Partition coefficients of aroma compounds in polysaccharide solutions by the phase ratio variation method. Food Chemistry, 85(3), 467-474.

Lan, H., Hoover, R., Jayakody, L., Liu, Q., Donner, E., Baga, M., et al. (2008). Impact of annealing on the molecular structure and physicochemical properties of normal, waxy and high amylose bread wheat starches. Food Chemistry, 111(3), 663-675.

Le Thanh, M., Thibeaudeau, P., Thibaut, M. A., \& Voilley, A. (1992). Interactions between volatile and non-volatile compounds in the presence of water. Food Chemistry, 43(2), 129-135.

Nuessli, J., Conde-Petit, B. a., Trommsdorff, U. R., \& Escher, F. (1995). Influence of starch flavour interactions on rheological properties of low concentration starch systems. Carbohydrate Polymers, 28(2), 167-170.

Nuessli, J., Sigg, B., Conde-Petit, B., \& Escher, F. (1997). Characterization of amyloseflavour complexes by DSC and X-ray diffraction. Food Hydrocolloids, 11(1), $27-34$.

Ratnayake, W. S., Jackson, D. S., \& Steve, L. T. (2008). Starch gelatinization. Advances in food and nutrition research (Vol. 55). Academic Press, pp. 221-268.

Rolée, A., \& Le Meste, M. (1999). Effect of moisture content on thermomechanical behavior of concentrated wheat starch-water preparations. Cereal Chemistry, $76(3), 452-458$

Rolée, A., \& Meste, Le. (1997). Thermomechanical behavior of concentrated starchwater preparations. Cereal Chemistry, 74(5), 581-588.

Roos, Y. H. (2010). Glass transition temperature and its relevance in food processing. Annual Review of Food Science and Technology, 1(1), 469-496.

Savary, G., Lafarge, C., Doublier, J.-L., \& Cayot, N. (2007). Distribution of aroma in a starch-polysaccharide composite gel. Food Research International, 40(6), 709-716.

Sun, Q., Dai, L., Nan, C., \& Xiong, L. (2014). Effect of heat moisture treatment on physicochemical and morphological properties of wheat starch and xylitol mixture. Food Chemistry, 143, 54-59.

Tang, M. C., \& Copeland, L. (2007). Analysis of complexes between lipids and wheat starch. Carbohydrate Polymers, 67(1), 80-85.

Taylor, A. J. (1998). Physical chemistry of flavour. International Journal of Food Science and Technology, 33(1), 53-62.

Tester, R. F., \& Debon, S. J. J. (2000). Annealing of starch - A review. International Journal of Biological Macromolecules, 27(1), 1-12.

Tester, R. F., Debon, S. J. J., \& Karkalas, J. (1998). Annealing of wheat starch. Journal of Cereal Science, 28(3), 259-272.

Tester, R. F., \& Morrison, W. R. (1990). Swelling and gelatinization of cereal starches. I. Effects of amylopectin, amylose, and lipids. Cereal Chemistry, 67(6), 551-557.

Vermeylen, R., Goderis, B., Reynaers, H., \& Delcour, J. A. (2005). Gelatinisation related structural aspects of small and large wheat starch granules. Carbohydrate Polymers, 62(2), 170-181.

Waigh, T. A., Gidley, M. J., Komanshek, B. U., \& Donald, A. M. (2000). The phase transformations in starch during gelatinisation: A liquid crystalline approach. Carbohydrate Research, 328(2), 165-176.

Zavareze, E. D. R., \& Dias, A. R. G. (2011). Impact of heat-moisture treatment and annealing in starches: A review. Carbohydrate Polymers, 83(2), 317-328. 